Routledge Studies in Entrepreneurship

\title{
CONTEXTUALIZING ENTREPRENEURSHIP THEORY
}

Ted Baker and Friederike Welter

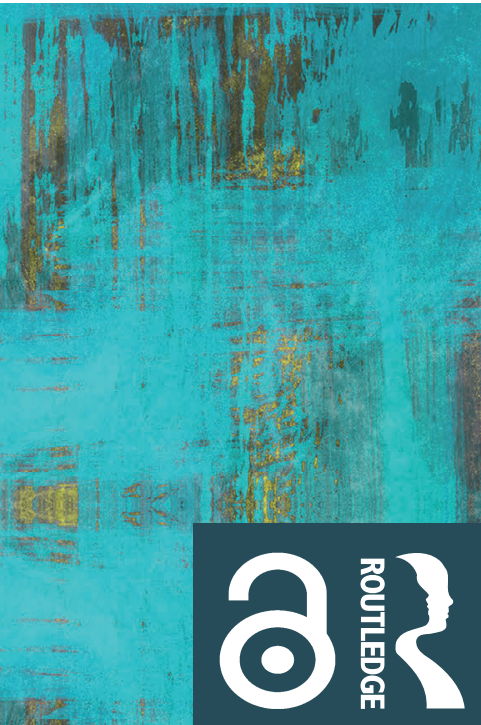




\section{Contextualizing Entrepreneurship Theory}

As the breadth and empirical diversity of entrepreneurship research have increased rapidly during the past decade, the quest to find a "one-sizefits-all" general theory of entrepreneurship has given way to a growing appreciation for the importance of contexts. This promises to improve both the practical relevance and the theoretical rigor of research in this field. Entrepreneurship means different things to different people at different times and in different places and both its causes and its consequences likewise vary. For example, for some people entrepreneurship can be a glorious path to emancipation, while for others it can represent the yoke tethering them to the burdens of overwork and drudgery. For some communities it can drive renaissance and vibrancy, while for others it allows only bare survival. In this book, we assess and attempt to push forward contemporary conceptualizations of contexts that matter for entrepreneurship, pointing in particular to opportunities for generating new insights by attending to contexts in novel or underexplored ways.

This book shows that the ongoing contextualization of entrepreneurship research should not simply generate a proliferation of unique theories-one for every context — but can instead result in better theory construction, testing and understanding of boundary conditions, thereby leading us to richer and more profound understanding of entrepreneurship across its many forms.

Contextualizing Entrepreneurship Theory will critically review the current debate and existing literature on contexts and entrepreneurship and use this to synthesize new theoretical and methodological frameworks that point to important directions for future research.

Ted Baker is George F. Farris Chair and Professor of Entrepreneurship at Rutgers Business School, Newark and New Brunswick, New Jersey, and Honorary Professor at the University of Cape Town Graduate School of Business, South Africa.

Friederike Welter is President and Managing Director of the Institut für Mittelstandsforschung (IfM) Bonn, and holds a professorship at the University of Siegen, Germany. 


\section{Routledge Studies in Entrepreneurship \\ Edited by Susan Marlow and Janine Swail \\ University of Nottingham, UK}

This series extends the meaning and scope of entrepreneurship by capturing new research and enquiry on economic, social, cultural and personal value creation. Entrepreneurship as value creation represents the endeavours of innovative people and organisations in creative environments that open up opportunities for developing new products, new services, new firms and new forms of policy making in different environments seeking sustainable economic growth and social development. In setting this objective the series includes books which cover a diverse range of conceptual, empirical and scholarly topics that both inform the field and push the boundaries of entrepreneurship.

Time, Space and Entrepreneurship

James O. Fiet

\section{Entrepreneurship and Global Cities}

Diversity, Opportunity and Cosmopolitanism

Edited by Nikolai Mouraviev and Nada K. Kakabadse

\section{A History of Enterprise Policy}

Government, Small Business and Entrepreneurship

Oliver Mallett and Robert Wapshott

\section{New Frontiers in the Internationalization of Businesses}

Empirical Evidence from Indigenous Businesses in Canada

Fernando Angulo-Ruiz

\section{Contextualizing Entrepreneurship Theory}

Ted Baker and Friederike Welter

For more information about this series please visit: www.routledge.com/ Routledge-Studies-in-Entrepreneurship/book-series/RSE 


\section{Contextualizing Entrepreneurship Theory}

\section{Ted Baker and Friederike Welter}


First published 2020

by Routledge

52 Vanderbilt Avenue, New York, NY 10017

and by Routledge

2 Park Square, Milton Park, Abingdon, Oxon, OX14 4RN

Routledge is an imprint of the Taylor \& Francis Group, an informa business

(C) 2020 Taylor \& Francis

The right of Ted Baker and Friederike Welter to be identified as authors of this work has been asserted by them in accordance with sections 77 and 78 of the Copyright, Designs and Patents Act 1988.

The Open Access version of this book, available at www. taylorfrancis.com, has been made available under a Creative Commons Attribution-Non Commercial-No Derivatives 4.0 license.

Trademark notice: Product or corporate names may be trademarks or registered trademarks, and are used only for identification and explanation without intent to infringe.

Library of Congress Cataloging-in-Publication Data

A catalog record for this book has been requested

ISBN: 978-0-8153-7156-4 (hbk)

ISBN: 978-1-351-11063-1 (ebk)

Typeset in Sabon

by Apex CoVantage, LLC 


\section{Contents}

Preface: Our Journey Towards Contextualizing Entrepreneurship Theory

\section{PART I}

Understanding Contexts and Entrepreneurship

1 Why Contexts Play an Ever-Increasing Role in Entrepreneurship Research

2 Synthesizing the Context Debate in Entrepreneurship Research

PART II

Theorizing Contexts

3 Constructing Contexts: Enacting, Talking, Seeing

4 Problematizing, Making Choices and Asking Who Our Research Serves

PART III

Studying Contexts

5 Some Heuristics for Researchers Embracing a Critical Process Approach

6 Narrating and Visualizing Contexts 
vi Contents

PART IV

Going Forward

7 Why It's Hard to Look Back Once You Have Embraced Contexts

Author Biographies

175

Index

176 


\section{Preface}

\section{Our Journey Towards \\ Contextualizing Entrepreneurship Theory}

\section{Ted Baker and Friederike Welter}

This book took us on a journey to other disciplines-both far (photography) and near (anthropology)—where we discovered, and just barely began to explore, treasure troves left by earlier explorers. After years of talking loosely about working together, we have recently taken the opportunity to write about something that has long concerned both of us: the failure of much of contemporary entrepreneurship research to seriously embrace the wondrous empirical diversity of entrepreneurship. One way of talking about this is to focus on "contexts" of entrepreneurship. A short monograph (Baker \& Welter, 2018) became the starting point for this book. In this volume we develop systematically some of the nascent ideas presented in Baker and Welter (2018) and move on to entirely new territory. We hope that this book suggests our profound respect for the remarkable work recently done by entrepreneurship researchers as well as the fun we had discovering new treasures around each corner. We remain critical on both practical and theoretical levels about what we see as the slowness of the field to expand its empirical and theoretical vision, and we develop at some length both our own critique of the field's conservatism and some ideas for moving forward. We wondered whether writing this book would get such things "out of our system". Instead, it has whetted our appetites. One sign of this is that much of the most interesting work we read these days seems to come from-at least to us, as social science researchers-fairly obscure corners. We invite other researchers to join us on a path that continues to embrace and to celebrate the disparaged, the invisible and the silenced among entrepreneurs.

\section{Reference}

Baker, T. \& Welter, F. (2018). Contextual entrepreneurship: An interdisciplinary perspective, Foundations and Trends in Entrepreneurship, 14(4): 357-426. 


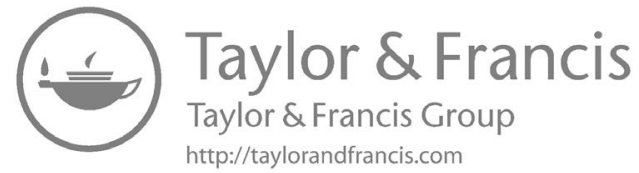




\section{Part I}

Understanding Contexts

and Entrepreneurship 


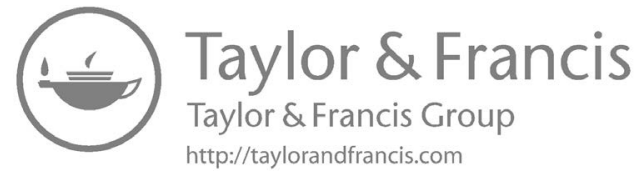




\section{Why Contexts Play an Ever-Increasing Role in Entrepreneurship Research}

In this chapter we briefly present some arguments regarding why we need to continue progress on building a contextualized perspective in entrepreneurship research, drawing on Welter (2011, p. 166) who stated that "(. . .) context is important for understanding when, how and why entrepreneurship happens and who becomes involved". As context has attracted increased attention in recent years, entrepreneurship scholars have begun to critically examine approaches and applications. Building on lessons about context from other disciplines, we make some suggestions-that we develop throughout the rest of the book-about how to avoid some of the pitfalls experienced in other fields and instead harness the "contextual turn" in entrepreneurship research in a theoretically interesting and practically useful way. Let's start by asking what context is before we begin making claims about why and how we should go about contextualizing our work.

\section{Defining Contexts-Or Not}

\section{Context and Entepreneurship: The Prequel}

There are two perspectives we will describe here on the complexities of context. The first comes from anthropology and related disciplines as well as from philosophers of social science and is focused on what has been often been called "cultural relativism". The second comes from organization studies and is more focused on questions and variables, functional form and model specification. These two perspectives provide challenges and opportunities to entrepreneurship researchers both alone and in combination.

Anthropologists, as well as scholars from a variety of liberal arts disciplines such as philosophy (Scharfstein, 1988) and literary studies (Akman, 2000; Felski, 2011), have struggled over how to choose and delimit how they contextualize their work. As Dilley (1999a, p. 1) points out, "Ever since Malinowski, anthropologists have chanted the mantra of 'placing social and cultural phenomena in context'". Ongoing debates about how to do this, which are too rich and varied to summarize easily, 


\section{Understanding Contexts and Entrepreneurship}

have persisted through the rise of structuralism, post-structuralism, postmodernism and a variety of other competing schools of thought and have resulted both in rich insights and many dead ends.

From one broad and persistent perspective, a key issue for anthropologists and other social scientists remains: what are the limits of understanding and "translating" one culture to make it understandable for members of another? For example, a large body of relevant research centers on the manner in which different languages may structure and shape how nativeborn speakers perceive and understand the world and the extent to which the meanings and understandings that result are commensurable (e.g., Bates, 1976; Duranti \& Goodwin, 1992; Labov, 1970; Levinson, 2003). Such arguments extend as well to cultural and linguistic subgroups.

Some "standpoint" theorists suggest that members of dominant and advantaged groups in any society are unlikely to be able to understand the perspectives or lived experiences of disadvantaged members. The disadvantaged members, however, are likely to be better able to understand their own experiences, those of more privileged members and, in turn, the society as a whole, because their disadvantage requires them to take into account both the position of the dominant members and their own (e.g., Collins, 1986; Harding, 2016; Hartsock, 1983). While such perspectives focus on showing how one "standpoint" can be epistemologically superior to others, generating something close to objective truth, others suggest that there is no such defensible standpoint for anyone to inhabit. Many authors have pointed out how an emphasis on contextualizing research therefore can lead easily to extreme forms of relativism (Culler, 1983; Dilley, 1999b; Scharfstein, 1989) and an infinite regress in which any attempt to apply a contextualizing lens on existing theoretical or descriptive claims is itself immediately subject to being undermined by its own failure to be fully contextualized.

Other behavioral scientists have had similar debates, for example, discussing "contextualism" as a concept and highlighting contextualizing processes through an emphasis on the interactions between contexts and individuals. Such discussions were particularly active during the 1980s. Rosnow and Georgoudi $(1986$, p. 3) pointed to the Latin root "contextus" as meaning "a joining together", asserting that this draws attention to a continously changing reality, the "relative and interpersonal nature of human understanding" and the "inseparable link between practical knowledge and fundamental knowledge". For them, human activity "is rigorously situated within a sociohistorical and cultural context of meanings and relationships", emphasizing that neither contexts nor actions can be assessed without consideration of the other (Rosnow \& Georgoudi, 1986 , p. 4). They explain their view of contexts as constructed (Rosnow \& Georgoudi, 1986, p. 19): "Contextualism views human beings not as separate from the world they know"; individuals are active in constructing contexts and contexts are not out there, but "part of the act" (p. 6). 


\section{Context Comes and Appears Unbounded in the Management Disciplines}

Coming at things from a less explicitly philosophical angle, organization studies was one of the first management disciplines to treat contexts as an object of focus. Johns's essays provide coherent and influential statements of why and how context matters to our understanding of organizations (Johns, 2006, 2017, 2018). The first is a theoretical piece in the Academy of Management Review (AMR). The second represents John's reflections on the first paper after it won AMR's "decade" award as the most important paper the journal published in 2006. The third nicely describes ways that "although context enables a demarcation of what is distinctive about situations, it also permits integration across research areas and levels of analysis, identifying what they have in common as settings for organizational behavior" (Johns, 2018, p. 21).

Although it is disciplined and grounded in its focus on specific bodies of empirical research, much like earlier work in anthropology and other fields, Johns's arguments nonetheless suggest that a commitment to contextualization can become unbounded both theoretically and empirically. Drawing on and synthesizing the approaches of some earlier scholars (e.g., Capelli \& Sherer, 1991; Mowday \& Sutton, 1993; Rousseau \& Fried, 2001), he defines contexts as "situational opportunities and constraints that affect the occurrence and meaning of organizational behavior as well as functional relationships between variables" (Johns, 2006, p. 386). He then shows how quickly contextualization can become unbounded, pointing out that the effects of any element we label context is itself likely dependent on context. He explains that elements of context can have offsetting effects and that in different "system" states, which become the context in which organizational behavior takes place, small changes can have small or very large effects. In his distinction between "discrete" and "omnibus" contexts, Johns (2006) shows that context writ large includes everything that might matter but that is not included in our models as well as whatever specific variables we might model. Any modeling strategy we might choose therefore includes within its "omnibus context" a universe of "omitted variables" (Johns, 2006, p. 388). High r-squared values do not signal an escape from this situation. Johns notes, for example, the problem of sampling-induced range restriction on key variables, suggesting that, when curvilinear effects exist, a high level of a variable effectively represents a different context than a low value on that same variable. Any model that fails to contain the full range of values on a variable that has curvilinear effects is therefore contextually constrained.

Context is typically used to point to characteristics at a higher level of analysis than the focus of a given study (e.g., how an industry affects an organization within it) but Johns elaborates how context can also 
point to characteristics at a lower level (e.g., how employee demographics affect organizations). He also provides several striking examples of context-driven "sign reversals", in which the effect of some variable-for example, the effect of tuition reimbursement programs on turnoverswitches from positive to negative depending on context; in this case, the presence or absence of associated promotion activities.

The multidimensionality of context makes understanding and accounting adequately for it more challenging. Describing Allport's (1937) "list of 17,953 trait names to describe people", Johns (2006, p. 391) suggests that these and more have been usefully consolidated to the "Big Five" in many studies. He points to the extreme multidimensionality of context-noting, for example, that as early as 1963 Sells provided a "list of 236 elements that might describe a total stimulus situation" and notes that no consolidation of contextual dimensions as useful as the "Big Five" has yet to occur. A quick scan of recent studies in micro-organizational behavior suggests that consolidation around the Big Five may be overstated. Many studies focus on specific traits with no clear ties to the Big Five. But all of that is just an oversimplification and a warmup to the challenges of contextualizing our work. Complex configurations-such as those in which "context effects can comprise both main effects and interactions between context variables and substantive variables of interest"-generate possibilities in which even a simple recitation of the permutations and combinations that might be expected to matter could quickly become overwhelming. Of course, everything is not connected to everything else. But even the question of which elements do not matter to some configuration-sometimes labeled "loose coupling"-boggles the mind.

Mind-boggling or not, we argue that Johns's list actually understates the magnitude of the challenge of contextualizing our research, even as these traits are implied by his own definition. Recall that he defines context as "situational opportunities and constraints that affect the occurrence and meaning of organizational behavior as well as functional relationships between variables" (Johns, 2006, p. 386). Organization scholars discussing context have focused their attention mainly on the last part of this, on functional relationships between variables and how they affect the occurrence of behavior. In a broad sense, however, as we described earlier, much of the serious scholarly reflection on context in other fields-perhaps especially by cultural anthropologists, linguists and philosophers of science-has tousled with issues and differences of meaning. This adds to both the challenges and the opportunities we face in thinking about how entrepreneurship researchers might usefully continue the process of contextualizing our work.

\section{How Entrepreneurship Researchers Define Contexts}

Drawing from the movement towards taking "environments" into consideration that swept organization theory during the 1970s (Aldrich \& 
Pfeffer, 1976), early entrepreneurship research talked about environments for entrepreneurship, treating these largely as objective differences in the situations entrepreneurs faced. This is still commonplace in organization studies. For example, in a review of research on extreme contexts the authors introduce extreme contexts as "environments" (Hällgren, Rouleau, \& de Rond, 2018, pp. 113, 115, building on the definition by Hannah et al. 2009). In a great deal of work, context still equals the common and objective environment to which organizations respond with more or less agency. For entrepreneurship research, we think the pattern is similar. An analysis of the reception of Welter (2011) by one of the authors of this book and her team shows that, out of 446 articles citing Welter's context article as of 31 July 2019, the majority (258) still reflected an understanding that "contexts are out there". We have no specific quarrel with such a common usage, but rather two concerns. First, work that treats context as "out there" and to be defined and measured without regard to the varied ways entrepreneurs might "do context" (on which we will elaborate much more throughout the book) leads us away from theorizing and studying the richness of entrepreneurial agency. Second, and more simply, such usage typically signals that work will understand context as something to be "controlled for" and taken into account or modeled in some very limited way.

We don't know why context and environment are still taken as synonyms by so many entrepreneurship researchers. This may be undergoing a generational change. When one of us asked doctoral students from several different cultural and disciplinary backgrounds to explain how they defined context, none of them mentioned "environment". Instead, their responses showed a wide and creative understanding of the concept, ranging from viewing context as the fundamental day-to-day reality in which we operate to seeing it as the intersection of the past, present and future. We are not saying that these descriptions are clear or that they converge on some single meaning; we are only saying that none of them equated context simply with environment. None of this is really novel. Much earlier, for example, Bengt Johannisson (1990) focused on parallel distinctions when he insisted on distinguishing between spatial environments and the links between actors and the community contexts in which they operated. As the contextual turn in entrepreneurship research continues, we rediscover not only lessons learned earlier by those in other fields but also lessons that were apparent to our own forbears. Undoubtedly, we will make claims in this book that will resonate with more seasoned scholars as ideas they've seen in other places and at other times.

\section{Why and How to Contextualize Entrepreneurship Research}

The urge to contextualize is a longstanding and recurring theme among some entrepreneurship researchers. Early research understood 


\section{Understanding Contexts and Entrepreneurship}

contextualization as a means to advance the field towards explanations of the entrepreneurial phenomenon rather than mere descriptions (Low \& MacMillan, 1988). For example, drawing on a review of early works by historians and development economists (Glade, 1967), Low and MacMillan (1988) showed how contextual models could improve our explanatory insights and theory development. Similarly, Ucbasaran, Westhead and Wright (2001, p. 67) argued for more studies that explored entrepreneurial behavior across widely different conditions. Entrepreneurship scholars also pointed to the multiplicity of sites where entrepreneurship takes place (Steyaert \& Katz, 2004, p. 180) as an important reason to contextualize, furthermore suggesting that contextualizing entrepreneurship research can add to both rigor and the relevance of our research (Zahra, 2007).

Over the past 20 years, moves to contextualize entrepreneurship research have generated a healthy process of debating the need for contextualization, challenging the patterns it has taken and promoting ideas about what is desirable and feasible for future contextualization (one might note that this characterization fits our current effort as well). According to Zahra (2007), judicious application of theories drawn from other parts of organization studies would continue to aid entrepreneurship researchers' efforts to contextualize our work. In management science and organization studies considered more broadly, context has been understood as, for example, surroundings (Capelli \& Sherer, 1991), stimuli in the external environment (Mowday \& Sutton, 1993) and situational opportunities that enable or constrain organizational behavior (Johns, 2006). Rousseau and Fried (2001, p. 1) provide a rather broad and optimistic cumulative "normal science" conceptualization, explaining that "[c]ontextualizing entails linking observations to a set of relevant facts, events, or points of view that make possible research and theory that form part of a larger whole". This optimism-that contextualization will allow better assembly of piece parts into a coherent whole-fits well with the Latin roots of the term, which refers to something that is woven together $(\mathrm{com}-=$ together + texere $=$ to weave). This theme could also be challenged in the sense that contextualization also-and perhaps more often-involves a process of fracturing our common understanding by placing stronger emphasis on differences.

Continued attention to contextualizing entrepreneurship research andas predicted by Zahra (2007) — the use of insights and perspectives drawn from other fields has led both to greater efforts by empirical researchers to better contextualize their work and to reflective commentaries on the state of the art and what else might be done. For example, Welter's (2011) paper, "Contextualizing Entrepreneurship-Conceptual Challenges and Ways Forward", which highlights "where" and "when" contexts, quickly shaped the conversation as scholars became increasingly self-conscious of the value of explicit attention to context in their work. Researchers have 
also become more attuned to treating differences in context as potentially both constitutive of and constituted by entrepreneurial behavior and outcomes (Frese, 2009; Welter \& Gartner, 2016). Particularly with the numbers of entrepreneurship scholars from-or at least studying phenomena-outside the mainly Western contexts that generated the standard assumptions of so much prior work, contexts seem in some ways to have taken on a life of their own. Something similar happened in parts of the organization studies research community a decade earlier. That earlier influx led Rousseau and Fried $(2001$, p. 1) to conclude that " $[t]$ he need to contextualize is reinforced by the emergence of a world-wide community of organizational scholars adding ever-greater diversity in settings as well as perspectives". It is our hope that the greater diversity of entrepreneurship scholars, including many less familiar or satisfied with current "Western" theories and concepts will continue bringing their own experiences and lenses to the field, rather than being brought to heel by the enforcement of existing assumptions and norms. There is something exciting about "our" assumptions and our taken-for-granted theories and management recipes being increasingly subjected to critical examination (Hamann, Luiz, Ramaboa, Khan, \& Dhlamini, 2019).

A contextualized perspective on entrepreneurship encourages us to see, consider and analyze varieties of entrepreneurship that too often remain invisible to us. This is not only about expecting and finding differences across geographies or industries, it is also about identifying and developing theory to discover and understand difference where we might otherwise expect sameness. For instance, why do the ventures set up by entrepreneurs with similar backgrounds, similar resource endowments and operating in the same institutional environments sometimes develop very differently? Why does one business grow, while the other stays small? Why are some businesses innovative and others in the same regions and industries not innovative? In our opinion, the present answers we have to such questions and many others are unsatisfying, stale and inadequate. Because contextualizing entrepreneurship is about acknowledging and accounting for variations and differences in the nature and patterns and meanings of entrepreneurship (Gartner, 2008), it not only urges us to greater sensitivity of typically hidden variation but can also shed new light onto seemingly well-known entrepreneurship phenomena. Furthermore, it will move our field out of the trap of "extreme de-contextualization" that has resulted from our too-simple and too-easy assumptions that have led us too often to treat all entrepreneurs and ventures as alike (Aldrich, 2009).

Entrepreneurship scholars have suggested several lists and typologies of contexts to guide how we contextualize entrepreneurship. For example, Zahra (2007) identified different phases of contextual richness in theory building, depending on whether the research phenomenon is well understood or new and whether the theory applied to explain the phenomenon is robust or early in its development. Zahra and Wright 
(2011, p. 75) suggest four context dimensions: spatial, time, practice and change; Zahra, Wright, and Abdelgawad (2014) extend this to incorporate business-related characteristics such as organizational, ownership and governance dimensions.

Drawing on Whetten (1989), Welter (2011) sees spatial and temporal dimensions as key to understanding context in entrepreneurship. She identifies four dimensions of where: business, which has been the default context for most entrepreneurship research; social (networks, households and families); spatial (urban versus rural places or communities) and institutional. To these she adds two dimensions of when: temporal and historical. Each element of context can be proximate to distal; for example, regulatory features of the institutional environment can operate at local, regional and national levels. Moreover, she illustrates how contexts cut across levels and interact, showing that context on a higher level of analysis (for example, the institutional context at the national level) interacts with the individual level (for example, the opportunity recognition of entrepreneurs), thus resulting in a context-specific outcome (for example, transition economy-specific venture ideas). She also emphasizes that contextual dimensions are interdependent and intertwined, implying that it is not one context alone that matters but the interactions between them and the agency of entrepreneurs in dealing with contexts.

These frameworks and similar typologies have motivated scholars to ask questions about who, what, when, where and why, and also have served as a checklist and analytical toolbox of factors to consider. Overall, typologies such as those outlined by Zahra and Wright (2011), Zahra et al. (2014) and Welter (2011) seem to have helped move contemporary research a little bit away from the naïve search for general laws of entrepreneurship resting-or teetering-on narrow empirical foundations (Hjorth, Jones, \& Gartner, 2008). However, such checklists and typologies can also rapidly become too complex. For example, the "institutional" dimension is itself an extraordinarily rich construct, as witnessed by the dominance and increasing complexity of institutional approaches to organizational theory. The history dimension can quickly become similarly overwhelming in its nuance and complexity; in addition, any account of history is highly susceptible to contestation about what is included and excluded. Much the same can be said about the elements of any typology listing elements or dimensions of context.

This leads us to conclude that work on theorizing entrepreneurship contexts has only just begun. With this book, we aim to contribute another perspective to this project. We will first synthesize existing work on context in entrepreneurship research. In Part II, we turn to theorizing contexts. We show how entrepreneurs "do contexts", enacting, talking about and seeing their environments. This leads to our outline for a Critical Process Approach (CPA). We hope the CPA provides a compelling answer to the question: when opportunities for contextualization 
are unbounded, what sorts of questions and choices can move us toward better science and toward more interesting and broadly useful research? In Part III of the book, we discuss how researchers can do contexts, outlining some useful heuristics for applying the CPA and then drawing on some novel research approaches from linguistics, visual disciplines and the arts. We end the book with Part IV, a short outlook as to what comes next once you start on the journey to contextualize your research.

\section{References}

Akman, V. (2000). Rethinking context as a social construct. Journal of Pragmatics, 32(6), 743-759.

Aldrich, H. E. (2009). Lost in space, out of time: Why and how we should study organizations comparatively. In B. G. King, T. Felin, \& D. A. Whetten (Eds.), Studying differences between organizations: Comparative approaches to organizational research (pp. 21-44). Bingley: Emerald Group Publishing Limited.

Aldrich, H. E., \& Pfeffer, J. (1976). Environments of organizations. Annual Review of Sociology, 2, 79-105.

Allport, G. W. (1937). Personality: A psychological interpretation. New York, NY: Holt.

Bates, E. (1976). Language and context: The acquisition of pragmatics. New York, NY: Academic Press.

Capelli, P., \& Sherer, P. D. (1991). The missing role of context in OB: The need for a meso-level approach. Research in Organizational Behavior, 13, 55-110.

Collins, P. H. (1986). Learning from the outsider within: The sociological significance of black feminist thought. Social Problems, 33(6), s14-s32.

Culler, J. (1983). On deconstruction: Theory and criticism after structuralism. London: Routledge \& Kegan Paul.

Dilley, R. (1999a). The problem of context. In R. Dilley (Ed.), The problem of context (pp. 1-46). Oxford; New York, NY: Berghahn Books.

Dilley, R. (Ed.). (1999b). The problem of context. Oxford; New York, NY: Berghahn Books.

Duranti, A., \& Goodwin, C. (1992). Rethinking context: Language as an interactive phenomenon. Cambridge: Cambridge University Press.

Felski, R. (2011). Context stinks. New Literary History, 42(4), 573-591.

Frese, M. (2009). Towards a psychology of entrepreneurship: An action theory perspective. Foundations and Trends® in Entrepreneurship, 5(6), 437-496.

Gartner, W. B. (2008). Variations in entrepreneurship. Small Business Economics, 31(4), 351-361.

Glade, W. P. (1967). Approaches to a theory of entrepreneurial formation. Explorations in Economic History, 4(3), 245-259.

Hällgren, M., Rouleau, L., \& de Rond, M. (2018). A matter of life or death: How extreme context research matters for management and organization studies. Academy of Management Annals, 12(1), 111-153.

Hamann, R., Luiz, J., Ramaboa, K., Khan, F., \& Dhlamini, X. (2019). Neither colony nor enclave: Calling for dialogical contextualism in management and organization studies. Organization Theory. Online early. 


\section{Understanding Contexts and Entrepreneurship}

Hannah, S. T., Uhl-Bien, M., Avolio, B. J., \& Cavarretta, F. L. (2009). A framework for examining leadership in extreme contexts. The Leadership Quarterly, 20(6), 897-919.

Harding, S. (2016). Whose science? Whose knowledge? Thinking from women's lives. Ithaca, N Y: Cornell University Press.

Hartsock, N. C. (1983). The feminist standpoint: Developing the ground for a specifically feminist historical materialism. In S. Harding \& M. B. Hintikka (Eds.), Discovering reality (pp. 283-310). Dordrecht: Springer.

Hjorth, D., Jones, C., \& Gartner, W. B. (2008). Introduction for recreating/ recontextualising entrepreneurship. Scandinavian Journal of Management, 24(2), 81-84.

Johannisson, B. (1990). Community entrepreneurship-cases and conceptualization. Entrepreneurship \& Regional Development, 2(1), 71-88.

Johns, G. (2006). The essential impact of context on organizational behavior. Academy of Management Review, 31(2), 386-408.

Johns, G. (2017). Reflections on the 2016 decade award: Incorporating context in organizational research. Academy of Management Review, 42(4), 577-595.

Johns, G. (2018). Advances in the treatment of context in organizational research. Annual Review of Organizational Psychology and Organizational Behavior, 5(1), 21-46.

Labov, W. (1970). The study of language in its social context. Berlin: Springer.

Levinson, S. C. (2003). Contextualizing contextualization cues. In S. L. Eerdmans, C. L. Prevignano, \& P. J. Thibault (Eds.), Language and interaction: Discussions with John J. Gumperz (pp. 31-39). Amsterdam, Philadelphia, PA: John Benjamins Publishing.

Low, M. B., \& MacMillan, I. C. (1988). Entrepreneurship: Past research and future challenges. Journal of Management, 14(2), 139-161.

Mowday, R. T., \& Sutton, R. I. (1993). Organizational behavior: Linking individuals and groups to organizational contexts. Annual Review of Psychology, 44, 195-229.

Rosnow, R. L., \& Georgoudi, M. (1986). The spirit of contextualism. In R. L. Rosnow \& M. Georgoudi (Eds.), Contextualism and understanding in behavioral science (pp. 3-22). New York, NY: Praeger.

Rousseau, D. M., \& Fried, Y. (2001). Location, location, location: Contextualizing organizational research. Journal of Organizational Behavior, 22(1), 1-13.

Scharfstein, B. A. (1988). The contextual fallacy. In G. J. Larson \& E. Deutsch (Eds.), Interpreting across boundaries: New essays in comparative philosophy (pp. 84-97). Princeton, NJ: Princeton University Press.

Scharfstein, B. A. (1989). The dilemma of context. New York, NY: New York University Press.

Sells, S. B. (1963). Dimensions of stimulus situations which account for behavior variance. In S. B. Sells (Ed.), Stimulus determinants of behavior (pp. 3-15). New York, NY: Roland.

Steyaert, C., \& Katz, J. A. (2004). Reclaiming the space of entrepreneurship in society: Geographical, discursive and social, dimensions. Entrepreneurship \& Regional Development, 16(3), 179-196.

Ucbasaran, D., Westhead, P., \& Wright, M. (2001). The focus of entrepreneurial research: Contextual and process issues. Entrepreneurship Theory and Practice, 25(4), 57-80. 
Welter, F. (2011). Contextualizing entrepreneurship: Conceptual challenges and ways forward. Entrepreneurship Theory and Practice, 35(1), 165-184.

Welter, F., \& Gartner, W. B. (Eds.). (2016). A research agenda for entrepreneurship and context. Cheltenham: Edward Elgar.

Whetten, D. A. (1989). What constitutes a theoretical contribution? Academy of Management Review, 14(4), 490-495.

Zahra, S. A. (2007). Contextualizing theory building in entrepreneurship research. Journal of Business Venturing, 22(3), 443-452.

Zahra, S. A., \& Wright, M. (2011). Entrepreneurship's next act. Academy of Management Perspectives, 25(4), 67-83.

Zahra, S. A., Wright, M., \& Abdelgawad, S. G. (2014). Contextualization and the advancement of entrepreneurship research. International Small Business Journal, 32(5), 479-500. 


\section{Synthesizing the Context Debate in Entrepreneurship Research}

In this chapter, our goal is to synthesize some of the progress to date as a way to introduce some ideas about to how to continue the process of contextualizing entrepreneurship research and theory. Throughout, our starting point is a critical appreciation of prior work and assessment of pathways forward. Building on and expanding our review in Baker and Welter (2018), we show how contextualization of entrepreneurship research has progressed from a rather simple interrogation of where and when contexts shaping entrepreneurship to a more nuanced and complex perspective that comprehends interactions between contexts and entrepreneurship and, more recently, between the construction and enactment of contexts.

\section{The Impact of Contexts on Entrepreneurship}

Among entrepreneurship scholars, the context debate gathered momentum in the early part of this century. In their conceptual review of the focus of entrepreneurial research, Ucbasaran, Westhead, \& Wright (2001) took Low and MacMillan's (1988) call for more contextualized research as their point of departure. Building on the open systems models that came to the fore in organization theory during the late 1970s (Aldrich \& Pfeffer, 1976; Katz \& Kahn, 1978; Scott, 1998), they focused attention on "environments" as context, insisting in particular that more attention to be paid to the variations in external environments of entrepreneurship. Their conceptual paper is representative of one still-popular strand of context research in entrepreneurship that focuses on how contexts affect entrepreneurship. Over time, these studies have become more nuanced by paying attention to the interactions and levels of contexts, as we will explore later in this chapter.

Concerning the "where" context label that Welter (2011) introduced, business has been and still is the default context for most entrepreneurship research. Studies look at, for example, the impact of industry sector, markets or resources on entrepreneurs and their ventures. Even today, De Massis, Kotlar, Wright and Kellermanns (2018, p. 5) assess the common approach to sector-based studies of entrepreneurship as one 
that is empirically driven and that models industry effects as controls, concluding that "context is typically viewed as differences that should be controlled for rather than theorized". The articles they assemble in their special issue nicely conceptualize contextual influences on and by agricultural entrepreneurship (Fitz-Koch, Nordqvist, Carter \& Hunter, 2018), theorize sectoral influences such as digital technologies (von Briel, Davidsson, \& Recker, 2018) and empirically examine various facets of entrepreneurship within the sports industry (Micelotta, Washington, \& Docekalova, 2018; Radaelli, Dell'Era, Frattini, \& Messeni Petruzzelli, 2018) and the TIME (Telecom, IT, media, entertainment-see McKelvie, Wiklund, \& Brattström, 2018) industry. In exploring themes of how context influences entrepreneurship, these papers indirectly demonstrate the challenges of moving beyond theorizing contexts as an exogenous and largely unmediated environmental influence on entrepreneurship. Part of this is due, of course, to the limitations of what any single empirical paper can accomplish. For example, von Briel et al. (2018) develop a compelling theory about "the role of digital technologies as objective, actor-independent factors within a process view of new venture creation" but are unable to say much about how the agency of entrepreneurs might shape the influence of the characteristics of digital technologies upon their work. This generally impressive special issue demonstrates the tenacious grip of the one-way, "environment to venture" imagery of context on our theoretical imagination.

Also popular are social network studies that highlight the impact of social context on entrepreneurship (for overviews see, e.g., Hoang \& Antoncic, 2003; Hoang \& Yi, 2015; Slotte-Kock \& Coviello, 2010). Social ties have been shown to matter in different ways for new and established businesses (e.g., Anderson, Dodd, \& Jack, 2010; Brüderl \& Preisendörfer, 1998; Greve \& Salaff, 2003; Jack, Dodd, \& Anderson, 2008; Lechner \& Dowling, 2003; Semrau \& Werner, 2014). Networks assist in overcoming liabilities of newness, smallness and adolescence when starting and growing businesses; they affect the financial resource base of enterprises, provide early and inexpensive information, access to opportunities and potential employees or clients; they also provide emotional support. Over time, this research has broadened its focus to include non-business-related social ties such as kinship, families and households that may constrain or foster entrepreneurship. For example, Renzulli, Aldrich, and Moody (2000) show one way that the composition of networks matters: in their study, social networks with a higher proportion of kin-related ties negatively impacted new venture creation. Aldrich and Cliff (2003) explore how long-term changes in families, as reflected in family composition and the relations and roles of family members, influence the recognition and exploitation of new business opportunities as well as resource availability, suggesting the need for a "family embeddedness" perspective in entrepreneurship research. 
Studies on portfolio entrepreneurship, farm and micro-businesses in rural areas have long argued for a household perspective on entrepreneurship because households offer opportunities, resources and emotional support but can simultaneously be a barrier for entrepreneurs (e.g., Carter \& Ram, 2003; Carter, Tagg, \& Dimitratos, 2004; Oughton, Wheelock, \& Baines, 2003). In their review of the literature on households as social contexts, Carter, Kuhl, Marlow, and Mwaura (2017) show how a household perspective allows a more differentiated view on resource acquisition, business decision making and business growth. They also disentangle the complex relations between household as a social and simultaneously spatial context, deepening our understanding of spatial context beyond the physical location of the business. Other studies extend consideration of spatial contexts to rural and peripheral as well as urban places and examine their impact on specific forms of entrepreneurship, as suggested by Steyaert and Katz (2004, p. 180), while pointing to a multiplicity of sites and places that we tend to neglect. Related to this, Wang's (2013) review of studies on spatial contexts illustrates that ethnic entrepreneurship is closely bound to place, often concentrated in ethnically dense residential neighborhoods or communities.

In part because large-scale datasets like the Global Entrepreneurship Monitor have facilitated access to measured institutional dimensions and have fostered cross-country comparisons, another popular research stream continues to examine the impact of institutional context on entrepreneurship. Generally, empirical studies support the long-assumed conclusion that institutions matter for entrepreneurship (for overviews, see: Bjørnskov \& Foss, 2016; Boettke \& Coyne, 2009; Bruton, Ahlstrom, \& Li, 2010; Henrekson, 2007; Welter \& Smallbone, 2012) and sometimes in complex and even surprising ways. For example, focusing on regulatory institutions, van Stel, Storey, and Thurik (2007) find that minimum capital requirements and labor market regulations can lower entrepreneurship rates, while administrative regulations (costs, time and number of procedures for setting up a firm) seem not to influence nascent or young businesses. Chowdhury, Terjesen, and Audretsch (2015) add to this, showing that the impact of institutions differs by form of entrepreneurship: property rights, freedom from corruption and fewer start-up procedures positively impact nascent and early-stage entrepreneurship, while tax and regulatory burdens facilitate self-employment but are negatively related to start-up activity. Thus, although newer research on institutional contexts still follows the dictum "contexts are out there and impact on entrepreneurship", their perspective has become more nuanced over time.

This holds as well for research that examines normative and culturalcognitive institutions and their impact on entrepreneurship (e.g., Thornton, Ribeiro-Soriano, \& Urbano, 2011; Tolbert, David, \& Sine, 2011). For example, in their study of cultural influences on opportunity- and 
necessity-based entrepreneurship, Hechavarria and Reynolds (2009, p. 434) demonstrate the general importance of normative and cultural institutions, showing that cultural values can predict "almost half of all explained variance in contextual motivation rates for entrepreneurship", going on to conclude that "contextual forces play a strong role in dictating human action". Exploring the example of gendered industries such as sports, Micelotta et al. (2018) examine the role of industry-specific socio-cultural institutions as facilitating or inhibiting new venture creation. They identify liabilities that new ventures in such industries face if they are not aligned with gender-specific normative institutions.

Institutions, especially normative ones, have been shown to be relatively persistent, only changing over long periods of time. In other words, history matters, although, in our opinion, it has been largely ignored as an element of context for a long time. Recently, business and economic historians (e.g., Jones \& Rose, 1993; Jones \& Wadhwani, 2006; Wadhwani, 2016) and entrepreneurship scholars (e.g., Aldrich, 2009; Landström, 2015; Landström \& Lohrke, 2010) have started to systematically introduce historical considerations and historical methods into entrepreneurship research. In doing this, the entrepreneurship field is following in the wake of other disciplines, including management and organization studies (for an overview see Bucheli \& Wadhwani, 2014; Godfrey, Hassard, O’Connor, Rowlinson, \& Ruef, 2016; Ingram, Rao, \& Silverman, 2012; Kipping \& Üsdiken, 2015).

Scholars applying institutional theories have a longer tradition of considering this "when" context and its impact on entrepreneurship. Studies have demonstrated the role of business history for the development of family firms (Colli, 2012; Lubinski, 2011), explored the historical roots of entrepreneurship in England and Germany and of the German small business sector (Berghoff, 2006; Berghoff \& Möller, 1994; Pahnke \& Welter, 2019) and argued for a closer look at historical influences on migration and entrepreneurship (Ram, Jones, \& Villares-Varela, 2017). Other research has studied path-dependent entrepreneurial behavior in unstable institutional contexts (e.g., Manolova \& Yan, 2002; Welter \& Smallbone, 2003; Welter \& Smallbone, 2015). For example, Smallbone and Welter (2001) illustrate that the social and institutional contexts inherited from the Soviet period shaped the nature and extent of entrepreneurship in post-Soviet countries. They show that in countries where the regulatory framework is not working properly, individuals draw on non-compliant behavior inherited from socialist periods-the so-called "legacies of non-compliance". Fritsch, Bublitz, Sorgner, and Wyrwich (2014) investigate the impact of institutional changes on the level and development of entrepreneurship in East Germany, identifying a continuous legacy spanning the socialist and even pre-socialist periods. Wyrwich (2013) shows that the socialist heritage is more of a constraint for those that grew up under socialism and for high-impact entrepreneurship, 
partly because of the lasting negative influence of socialism on how people think about entrepreneurship-which is confirmed by Fritsch, Obschonka, and Wyrwich (2019), who show the relation between historically high regional entrepreneurship levels and characteristics of the local population. Fritsch, Sorgner, Wyrwich, and Zazdravnykh (2019)'s study on the historical roots of entrepreneurship in Kaliningrad suggests that entrepreneurial traditions can survive over long periods of time.

Not only do these and similar studies point to the importance of history as context, but they also, albeit implicitly, introduce time-in this case historical time-as a dimension of context. Scholars constantly acknowledge the importance of time both in distinctions such as "nascent" versus "operational" ventures and through a variety of attempts to posit stage models of entrepreneurial development (Hansen \& Bird, 1998; also see the review by Levie \& Lichtenstein, 2010). The journal Entrepreneurship Theory and Practice published a special issue on "Time and Entrepreneurship" as early as 1998 (Bird \& West, 1998). Then, most of the papers applied a simple commonsense understanding of time as linear and sequential (Cooper, Ramachandran, \& Schoorman, 1998; Das \& Teng, 1998; Lévesque \& Maccrimmon, 1998; West \& Meyer, 2017). A few, however, suggested radically different conceptualizations of the temporal contexts for entrepreneurship (Fischer, Reuber, Hababou, Johnson, \& Lee, 1998; Slevin \& Covin, 1998), pointing to time as a construction and as enacted. Nonetheless, time as context for entrepreneurial activities has so far received only sparse and scattered theoretical attention (Lippmann \& Aldrich, 2016b); it is more often assumed than studied and still too frequently pointed to as a "direction" for future research, especially in cross-sectional studies that call upon others to do longitudinal work.

Summing up, the widespread, simple, one-way and generally linear understanding of context as shaping entrepreneurship has had the great merit of bringing a contextualized perspective on entrepreneurship to our attention. Research has clearly demonstrated that contexts obviously constrain, but often also enable and foster entrepreneurship. However, the overall contribution of this contextual perspective to the entrepreneurship field is limited (Welter, 2011) for several reasons. First, this perspective too often treats context as static and as both prior to and external to the entrepreneurship being studied. Second, and relatedly, context is often seen mainly as "environment" and not much theorized but instead operationalized by inserting one or more control variables. Third, the factors assumed and measured as important mostly are simply those at the next higher level of analysis: for example, if the focal level of analysis was the firm, the industry or region is likely to be considered the primary context. Fourth, largely as a result of the first three restrictions, the typical perspective on context and entrepreneurship does not conceptualize adequately (or at all) interactions between different elements or 
levels of context, or the role of the entrepreneurs in enacting contexts or defining the situations they face in various ways.

\section{Contexts Interact to Shape Entrepreneurship}

The limitations of the contextual perspective on entrepreneurship outlined in the previous section have become more apparent as some researchers have started to take context more seriously, as both a theoretical and methodological lens. Welter and Gartner (2016, p. 156) suggested a move towards talking about "contexts", to acknowledge the "diversity, heterogeneity and multiplicity required to adequately contextualize" our work. This is reflected in research that has started to analyze and conceptualize interactions within contexts. One stream turned to study the complex interactions within institutional contexts, namely of formal and informal institutions and the resulting impact on entrepreneurship. This interplay is complex: normative institutions can weaken, compensate and substitute for or can reinforce regulatory institutions and vice versa (Welter \& Smallbone, 2011). Often, institutional asymmetries such as a misfit between regulatory and normative institutions open up so-called "institutional holes" (Yang, 2004) or "institutional voids" (McCarthy \& Puffer, 2016; Puffer, McCarthy, \& Boisot, 2010; Webb, Khoury, \& Hitt, 2019; Williams \& Vorley, 2015), which either constrain or foster entrepreneurship when entrepreneurs exploit these holes to their own benefit. Even regulatory institutions can be inconsistent across, for example, different levels of government. One such example refers to the current state of regulation of marijuana in the United States: it is legal for medical use in many states and legal for recreational use in some, but it is illegal everywhere under national statutes. Several studies have now demonstrated that it is the mixture of regulatory and normative institutions that matters for entrepreneurship. This has been shown, for example, in research that compares national differences in (varieties of) entrepreneurship (Estrin, Mickiewicz, \& Stephan, 2013; Robson, 2010; Stenholm, Acs, \& Wuebker, 2013), for the relation between the institutional mix, the quality and quantity of entrepreneurship and the level of economic development in a country (Chowdhury, Audretsch, \& Belitski, 2019), for the forms of entrepreneurship impacted by that interaction (Webb et al., 2019), and for the nature and extent of entrepreneurship in emerging market economies (Estrin \& Prevezer, 2010; Welter \& Smallbone, 2011). In this regard, Stephan, Uhlaner, and Stride (2015) advance a muchneeded nuanced view on the interplay of formal and informal institutions in creating institutional support for, in their study, social entrepreneurs.

Other studies have looked into the interactions of different institutions with ethnic entrepreneurship (Carter, Mwaura, Ram, Trehan, \& Jones, 2015) or with women's entrepreneurship (e.g., Estrin \& Mickiewicz, 2011; Lewellyn \& Muller-Kahle, 2015; Pathak, Golz, \& Buche, 2013). 


\section{0}

In some studies, women entrepreneurs appear to react more positively to normative institutions such as recognition of their entrepreneurial activities and to benefit from strong normative support and close social ties (e.g., Baughn, Chua, \& Neupert, 2006; Noguera, Alvarez, Merigó, \& Urbano, 2015). In relation to the institutional mix, Yousafzai, Saeed, and Muffatto (2015) illustrate that regulatory and normative institutions not only directly affect women's entrepreneurship but that they also have an indirect effect, through their impact on a country's vision for women's entrepreneurship. Favorable regulatory institutions (few procedures to start a business), together with media attention paid to entrepreneurship (normative institutions) and entrepreneurial skills, lower fear of failure and the presence of entrepreneurial role models (cultural-cognitive dimensions of context) generally have been shown to increase the probability of entrepreneurship (Urbano \& Alvarez, 2014). Overall, normative institutions seem to have a larger impact on expressed preferences for entrepreneurship, while regulatory institutions appear to more strongly influence actual entrepreneurial activity.

Another stream of research explores the interactions between different (levels of) contexts. Popular are studies that analyze the interactions between business, institutional and social contexts. For example, Aldrich and Cliff (2003) acknowledge the multiple interactions between contexts in concluding that a family embeddedness perspective on entrepreneurship is required, which considers family contexts, the institutional origins of family roles and business contexts as intertwined. Others have suggested the concept of family entrepreneurship as a "field of research that studies entrepreneurial behaviors of family, family members and family businesses" and "the possible interplays among them" (Bettinelli, Fayolle, \& Randerson, 2014, p. 161; Randerson, Bettinelli, Fayolle, \& Anderson, 2015). An emerging strand of research has called for more attention to (family) business groups (Rautiainen, Rosa, Pihkala, Parada, \& Discua Cruz, 2019), which also may provide novel insights into how the family context influences and interacts with business (and other) contexts.

A wider perspective on family interacting with business and spatial contexts has (implicitly) been applied in some of the research on informal entrepreneurship (e.g., Khavul, Bruton, \& Wood, 2009; Welter, Smallbone, \& Pobol, 2015; Welter, Xheneti, \& Smallbone, 2018). Welter et al. (2014) show entire families being involved in cross-border informal entrepreneurship, facilitating these entrepreneurial activities, regardless of whether they lived together in one household or across borders in different countries. For markets at the "bottom of the pyramid", Webb, Pryor, and Kellermanns (2015) present a model of household enterprises that are embedded simultaneously in family relations and institutionsin this case examining how such household enterprises can use income diversification to reduce their poverty. Such diversification strategies as a means for enterprise development have been studied widely with regard 
to (informal) entrepreneurship in former Soviet economies and elsewhere (e.g., Manolova \& Yan, 2002; Smallbone \& Welter, 2001; Welter \& Smallbone, 2011), demonstrating the agency entrepreneurs have in adapting or manipulating their institutional and business contexts and belying notions of context as exogenous environments to be treated as separate from entrepreneurial action and agency.

Similarly, De Clercq, Danis, and Dakhli (2010) show how the social context, viewed in their study as social networks, may substitute for weak formal and informal institutions: they find a positive relation between new business activity and "associational activity" within a country-and this relationship is made stronger by higher regulatory and normative institutional constraints and by lower cognitive institutional constraints. Similar studies have explored the networking practices that are common in specific institutional environments, such as guanxi in China (Burt \& Burzynska, 2017) or blat in post-Soviet countries (Ledeneva, 1998, 2008; Onoshchenko \& Williams, 2013). Moreover, the ways in which social, spatial and institutional contexts interact also has generated novel explanations for variations in the behavior of women entrepreneurs and new insights into the differences between women- and men-owned businesses (e.g., Baughn et al., 2006; Coleman, 2016; Elam \& Terjesen, 2010; Gupta, Turban, \& Pareek, 2013; Welter \& Smallbone, 2008, 2010).

Some research has studied the interactions of different levels of spatial contexts, often focusing on rural or peripheral contexts and hinting at ways that entrepreneurs are sometimes able to influence and change their contexts. From a conceptual perspective, Korsgaard, Müller, and Tanvig (2015) distinguish entrepreneurship that is located but not embedded in rural contexts, while following a pure profit orientation and being spatially mobile, versus rural entrepreneurship that leverage local resources, enacts strong local embeddedness and is unlikely to relocate to a different spatial context. Where entrepreneurs are not (fully) embedded locally, they are quicker to relocate, thus creating bridges between contexts while those remaining in place create different value for the community (Korsgaard et al., 2015). Dubois (2016) expands on this idea, drawing attention to "translocal embeddedness", particularly in rural regions. Based on case studies with five rural enterprises that had internationalized globally, he shows that "global engagement could act as a cohesive force for the local" (Dubois 2016, p. 10) because entrepreneurs turned to local routines and trusted ways of networking, for example, in order to manage their global business relations. Such "glocalisation" (Johannisson, 2009) is both an outcome of and an input to entrepreneurs' enactment of spatial contexts.

Other research draws attention to the complex interplay of various contexts and how they shape entrepreneurship. For example, Lang, Fink, and Kibler (2014) argue that institutions are inherently place-bound, thus explaining the differences in change practices of entrepreneurs located 


\section{2}

\section{Understanding Contexts and Entrepreneurship}

in rural transition and rural non-transition areas. For ethnic entrepreneurship, Wang (2013) offers a multi-scale spatial framework, integrating business, social and institutional contexts. Yet, there are still too few studies that also bring in history and time. An exception is Kasabov and Sundaram (2014), who illustrate the interactions of history, temporal, spatial and institutional contexts. They study the role of governance institutions and mechanisms in shaping enterprising places over a long period of time, using the example of the British city of Coventry from the early-middle ages to the present. The authors argue that enterprising places need to be understood in terms of a "confluence of historical synergies across centuries" (Kasabov \& Sundaram, 2014, p. 50), thus drawing our attention strongly to the processual and temporal nature of contexts and their influence on entrepreneurship.

Entrepreneurship research has long attended to some unique circumstances outside of modern capitalist economies, looking at, for example, emerging market economies in former post-Soviet countries (e.g., Ageev, Gratchev, \& Hisrich, 1995; Ahlstrom \& Bruton, 2010; Aidis \& Welter, 2008a, 2008b; Smallbone \& Welter, 2001, 2009; Smallbone, Welter, \& Ateljevic, 2014) and other parts of the world (e.g., Bruton, Ahlstrom, \& Obloj, 2008; Fadahunsi \& Rosa, 2002; Frederick, 2008; Mwega, 1991; Naudé \& Havenga, 2005), frequently focusing on particular subsets of entrepreneurs, for example, women (e.g., Hodges et al., 2015; Kwami, 2015; Scott, Dolan, Johnstone-Louis, Sugden, \& Wu, 2012). Several of these studies question our Western-based theories and approaches, illustrating how these need to be contextualized, as Smallbone and Welter (2006) suggested based on their studies of entrepreneurship in former Soviet countries. Recently, this has become a much more prominent theme. The rise of research on Chinese entrepreneurship by both Chinese and Western researchers (e.g., Ahlstrom, Bruton, \& Yeh, 2008; Lee \& Hung, 2014; Nee \& Matthews, 1996; Roberts \& Zhou, 2000; Smallbone \& Welter, 2012; Smallbone, Welter, \& Jianzhong, 2011; Su, Zhai, \& Landström, 2015; Su, Xie, \& Wang, 2015; White, Hoskisson, Yiu, \& Bruton, 2008; Zhou, Xu, \& Shenasi, 2016; Zhou \& Teng, 2003), and related work on varieties of capitalisms (e.g., Carney, Gedajlovic, \& Yang, 2009; Hall \& Thelen, 2009; Tracey, Phillips, \& Jarvis, 2011) have brought the importance of contextualizing entrepreneurship to the forefront. At the same time, this work has begun to challenge some often-hidden assumptions by showing how entrepreneurs both shape and are shaped by the contexts in which they live and operate. Implicitly, these and similar studies that explore the complex relations between entrepreneurs and spatial, institutional, temporal and historical contexts (Baker \& Powell, 2016; Lippmann \& Aldrich, 2016a, 2016b; Wadhwani, 2016) again allude to the agency entrepreneurs have in dealing with their contexts. This will be one of the building blocks of our theorizing contexts discussion in Part II of this book. 


\section{Entrepreneurs Impact Contexts}

More recently, context research has started to move farther away from the original notion of "contexts are out there and they impact on entrepreneurship", towards studying how contexts are also constructed and enacted through the actions of the entrepreneur (Griffin, 2007), their cognitions and intentions (e.g., Brännback \& Carsrud, 2016; Elfving, Brännback, \& Carsrud, 2009; Elfving, Brännback, \& Carsrud, 2017) and, generally, their ways of understanding and making sense of the world (e.g., Drakopoulou Dodd, Pret, \& Shaw, 2016; Fletcher \& Selden, 2016; Gartner, 2016; Steyaert, 2016; Welter, 2019). This is apparent in, for example, the more nuanced perspective regarding the business context that has emerged over time, acknowledging that entrepreneurs also construct new sectors (De Massis et al., 2018). This thought is not new, of course, but in a way rediscovers and supports Aldrich and Fiol (1994)'s theorization of the processes through which entrepreneurs contribute to industry creation. Scholars have introduced the concept of "institutional entrepreneurship" to capture the agency of entrepreneurs towards their institutional contexts (e.g., Battilana, Leca, \& Boxenbaum, 2009; Leca \& Naccache, 2006; Li, Feng, \& Jiang, 2006; Pacheco, York, Dean, \& Sarasvathy, 2010). Institutional entrepreneurs have often been portrayed as potently agentic-as heroes who actively and with deliberate intentions bring big changes to their institutional contexts. This imagery has engendered some backlash. Clegg (2010, p. 5) suggests this approach as de-contextualized, neglecting the social contexts of individual actions, whilst Aldrich (2010) critiqued it for not adequately capturing the complexities of the interplay between context and individuals, not least because it neglects the reflexivity of agents and the messiness of institutional change, by portraying "heroes and successes in a linear time line” (Weik, 2011, p. 472). Therefore, in their cross-disciplinary review of institutional entrepreneurship research, Welter and Smallbone (2015) suggested that researchers avoid the heroic-sounding label and imagery of the institutional entrepreneur in favor of broader study of institutional change agents-and the contexts that constrain and enable them-along with the role that everyday entrepreneurs may or may not play in shaping intentional institutional change.

Other research has set out to critique some of the broad assumptions that guide large swaths of entrepreneurship research (Rehn, Brännback, Carsrud, \& Lindahl, 2013), questioning our fascination with high-growth entrepreneurship (Brännback, Kiviluoto, Carsrud, \& Östermark, 2010; Kiviluoto, 2013), showing how institutional logics can inform a more nuanced picture of entrepreneurial actions within and towards their contexts (Greenman, 2013), exploring the myths of informality or illegality for ethnic entrepreneurship in the U.K. (Ojo, Nwankwo, \& Gbadamosi, 2013), studying the diversity of entrepreneurship—and the sometimes 


\section{Understanding Contexts and Entrepreneurship}

numerical dominance of informal ventures-within the same country context (Williams \& Nadin, 2013) and critically discussing the "optimistic" narratives of support organizations and the different ways women ethnic entrepreneurs in the Netherlands deal with such ideological tales (Verduijn \& Essers, 2013). These studies and similar research illustrate the value of contextualizing entrepreneurship as a means to acknowledge its heterogeneity while highlighting some of our assumptions that serve as restrictive myths, preventing us from expanding our understanding of the full range of human activities involved in entrepreneurship or developing robust theories to explain and understand it. Alas, this last point caused us to veer off into examining how we as researchers participate in contextualizing entrepreneurship-a theme we will explore much further in Part II of this book.

Along similar lines, the recent flurry of studies showing the heterogeneity in entrepreneurship across different contexts examine the role that historical and other contextual influences play in generating this variety, and explore how the heterogeneity of entrepreneurship in turn influences those contexts, demonstrating the richness and the continuing promise of a contextual perspective. A recent special issue of Small Business Economics on context in entrepreneurship presents papers that by and large are all critical of the so-called Silicon Valley Model (SVM) of entrepreneurship. For example, Pahnke and Welter (2019) discuss whether the so-called Mittelstand model (owner-managed small- and medium-sized businesses) in Germany is antithesis to the SVM. Simply, the Mittelstand model is seen as outdated, a model whose times are gone by while Silicon Valley entrepreneurship is perceived and promoted as the future for entrepreneurship. The models are not antithetical, but exist side-by-side, and are also more similar than the public, media and-some-entrepreneurship researchers seem to want to acknowledge. Similarly, Lehmann, Schenkenhofer, and Wirsching (2019) show the context-dependency of Germany's "hidden champions". Applying the Varieties of Capitalism (VOC) concept to entrepreneurship, Herrmann (2019) argues that the VOC approach allows us to explain important variations in innovation amongst new ventures.

\section{Summing Up and Moving Towards Theorizing Contexts}

To sum up, our synthesis shows how research attempting to contextualize our understanding of entrepreneurship has developed over time, partially decentring and showing the "heroic", "alert" and "enterprising" individual entrepreneur to be a rather limited special case and instead drawing our attention towards the "everyday" of entrepreneurship (Steyaert \& Katz, 2004; Welter, Baker, Audretsch, \& Gartner, 2017). Van Gelderen and Masurel (2012) have edited an anthology in which half of the chapters show how contexts shape entrepreneurship, while 
some already uncover themes of entrepreneurial agency. The 22 chapters in Ramirez-Pasillas, Brundin, and Markowska (2017) are classified as examining how context shapes entrepreneurial practice "top down", how entrepreneurial practice shapes context "bottom up", and importantly, as examining "hybrid" processing encompassing the interaction of top-down and bottom-up dynamics. Other edited volumes focus on specific spatial contexts (e.g., Mason, Reuschke, Syrett, \& van Ham, 2015; Van Ham, Reuschke, Kleinhans, Mason, \& Syrett, 2017) or the interaction of gender and others with specific socio-cultural contexts (Yousafzai, Lindgreen, Saeed, Henry, \& Fayolle, 2018). This exciting outpouring of work suggests the emergence of important pathways towards entrepreneurship scholars grasping more of the complexities of context.

In the sense that it examines and highlights boundaries and limitations of prior research, much of the "contextualizing" research we have described in this chapter can be labeled "critical". But some of it is more explicitly and adamantly critical because it reveals uncomfortable patterns about the contextual landscapes in which entrepreneurship takes place and which therefore provide the grounding for our research. The strongest examples of such a useful critical approach comes from research on women's entrepreneurship. During the past 30 years, critical voices have revealed and offered correctives for a whole series of taken-for-granted assumptions about women doing entrepreneurship. Unfortunately, at this point in the emergence of entrepreneurship research, theory and practice, such critical lenses remain largely underdeveloped in much of our work. As critical voices slowly emerge (e.g., Tedmanson, Verduyn, Essers, \& Gartner, 2012; Verduyn et al., 2014), they are still too often marginalized, toned down or silenced in mainstream entrepreneurship discourse. Instead, too much entrepreneurship research serves as a reflection of powerful legitimating interests and perspectives (Baker \& Welter, 2017; Welter et al., 2017) portraying, for example, both too broad a sense (Baker \& Powell, 2016) and too narrow a sense (e.g., Al-Dajani \& Marlow, 2015; Rindova, Barry, \& Ketchen, 2009) but hardly ever a realistic sense of the possibilities of entrepreneurship as emancipation.

Contextualization is also likely to serve a useful critical function when it demands and attracts attention to perspectives that have remained unheard not because they are illegitimate or contrary to interests in maintaining the status quo, but rather because they are deemed not interesting. It is not uncommon for the contexts in which entrepreneurship takes place to be contorted by power, domination, oppression, inequality and violence. Too often, both we and the people we study blissfully ignore and take for granted these contours of inequality, in part because those whom we study and hold up as real or true or interesting or important entrepreneurs often traverse privileged paths to their roles. Much of the work synthesized in this chapter has helped to challenge the assumptions of the "standard model" of entrepreneurship, at first mostly implicitly, later on 


\section{Understanding Contexts and Entrepreneurship}

more explicitly, undermining the often taken-for-granted notion of large and growing profit streams as the sole or even primary focus of most entrepreneurs (Korsgaard \& Anderson, 2011). Baker and Welter (2017) propose the term "doing context" for entrepreneurs' active involvement in the construction and enactment of contexts rather than passively experiencing them. Researchers also do context, in making choices about the theories, assumptions and research approaches guiding their interest and research questions. Both types of doing context are central to our theorizing of contexts to which we will turn in Part II of the book. We argue that there is little hope of developing an adequate general theory of entrepreneurship contexts and suggest that a useful path forward is through studying entrepreneurs "doing context" and through researchers "doing context" using what we call a "Critical Process Approach".

\section{References}

Ageev, A. I., Gratchev, M. V., \& Hisrich, R. D. (1995). Entrepreneurship in the Soviet-Union and post-socialist Russia. Small Business Economics, 7(5), 365-376.

Ahlstrom, D., \& Bruton, G. D. (2010). Rapid institutional shifts and the coevolution of entrepreneurial firms in transition economies. Entrepreneurship Theory and Practice, 34(3), 531-554.

Ahlstrom, D., Bruton, G. D., \& Yeh, K. S. (2008). Private firms in China: Building legitimacy in an emerging economy. Journal of World Business, 43(4), 385-399.

Aidis, R., \& Welter, F. (Eds.). (2008a). The cutting edge: Innovation and entrepreneurship in New Europe. Cheltenham: Edward Elgar.

Aidis, R., \& Welter, F. (Eds.). (2008b). Innovation and entrepreneurship: Successful start-ups and businesses in emerging economies. Cheltenham: Edward Elgar.

Al-Dajani, H., \& Marlow, S. (2015). Empowerment, place and entrepreneurship. In T. Baker \& F. Welter (Eds.), The Routledge companion to entrepreneurship (pp. 343-357). London: Routledge.

Aldrich, H. (2009). Lost in space, out of time: Why and how we should study organizations comparatively. In B. G. King, T. Felin, \& D. A. Whetten (Eds.), Studying differences between organizations: Comparative approaches to organizational research (pp. 21-44). Bingley: Emerald Group Publishing Limited.

Aldrich, H. (2010). Beam me up, Scott(ie)! Institutional theorists' struggles with the emergent nature of entrepreneurship. In D. S. Wesley \& J. D. Robert (Eds.), Institutions and entrepreneurship (pp. 329-364). Bingley: Emerald Group Publishing Limited.

Aldrich, H., \& Cliff, J. E. (2003). The pervasive effects of family on entrepreneurship: Toward a family embeddedness perspective. Journal of Business Venturing, 18(5), 573-596.

Aldrich, H., \& Fiol, C. M. (1994). Fools rush in? The institutional context of industry creation. The Academy of Management Review, 19(4), 645-670.

Aldrich, H., \& Pfeffer, J. (1976). Environments of organizations. Annual Review of Sociology, 2, 79-105. 
Anderson, A. R., Dodd, S. D., \& Jack, S. (2010). Network practices and entrepreneurial growth. Scandinavian Journal of Management, 26(2), 121-133.

Baker, T., \& Powell, E. E. (2016). Let them eat bricolage? Toward a contextualized notion of inequality of entrepreneurial opportunity. In F. Welter \& W. B. Gartner (Eds.), A research agenda for entrepreneurship and context (pp. 41-53). Cheltenham: Edward Elgar.

Baker, T., \& Welter, F. (2017). Come on out of the ghetto, please: Building the future of entrepreneurship research. International Journal of Entrepreneurial Behaviour \& Research, 23(2), 170-184.

Baker, T., \& Welter, F. (2018). Contextual entrepreneurship: An interdisciplinary perspective. Foundations and Trends in Entrepreneurship, 14(4), 357-426.

Battilana, J., Leca, B., \& Boxenbaum, E. (2009). How actors change institutions: Towards a theory of institutional entrepreneurship. Academy of Management Annals, 3, 65-107.

Baughn, C. C., Chua, B. L., \& Neupert, K. E. (2006). The normative context for women's participation in entrepreneurship: A multicountry study. Entrepreneurship Theory and Practice, 30(5), 687-708.

Berghoff, H. (2006). The end of family business? The Mittelstand and German capitalism in transition, 1949-2000. The Business History Review, 80(2), 263-295.

Berghoff, H., \& Möller, R. (1994). Tired pioneers and dynamic newcomers? A comparative essay on English and German entrepreneurial history, 18701914. The Economic History Review, 47(2), 262-287.

Bettinelli, C., Fayolle, A., \& Randerson, K. (2014). Family entrepreneurship: A developing field. Foundations and Trends ${ }^{\circledR}$ in Entrepreneurship, 10(3), 161-236.

Bird, B. J., \& West, G. P. (1998). Time and entrepreneurship. Entrepreneurship Theory and Practice, 22(2), 5-9.

Bjørnskov, C., \& Foss, N. J. (2016). Institutions, entrepreneurship, and economic growth: What do we know and what do we still need to know? Academy of Management Perspectives, 30(3), 292-315.

Boettke, P. J., \& Coyne, C. J. (2009). Context matters: Institutions and entrepreneurship. Foundations and Trends ${ }^{\circledR}$ in Entrepreneurship, 5(3), 135-209.

Brännback, M., \& Carsrud, A. (2016). Understanding entrepreneurial cognitions through the lenses of context. In F. Welter \& W. B. Gartner (Eds.), A research agenda on entrepreneurship and context (pp. 16-27). Cheltenham: Edward Elgar.

Brännback, M., Kiviluoto, N., Carsrud, A., \& Östermark, R. (2010). Much ado about nearly nothing? An exploratory study on the myth of high growth technology start-up entrepreneurship. Frontiers of Entrepreneurship Research, 30(12), 1.

Brüderl, J., \& Preisendörfer, P. (1998). Network support and the success of newly founded businesses. Small Business Economics, 10(3), 213-225.

Bruton, G. D., Ahlstrom, D., \& Li, H. L. (2010). Institutional theory and entrepreneurship: Where are we now and where do we need to move in the future? Entrepreneurship Theory and Practice, 34(3), 421-440.

Bruton, G. D., Ahlstrom, D., \& Obloj, K. (2008). Entrepreneurship in emerging economies: Where are we today and where should the research go in the future. Entrepreneurship Theory and Practice, 32(1), 1-14. 


\section{Understanding Contexts and Entrepreneurship}

Bucheli, M., \& Wadhwani, R. D. (Eds.). (2014). Organizations in time: History, theory, methods. Oxford: Oxford University Press.

Burt, R. S., \& Burzynska, K. (2017). Chinese entrepreneurs, social networks, and guanxi. Management and Organization Review, 13(2), 221-260.

Carney, M., Gedajlovic, E., \& Yang, X. (2009). Varieties of Asian capitalism: Toward an institutional theory of Asian enterprise. Asia Pacific Journal of Management, 26(3), 361-380.

Carter, S., Kuhl, A., Marlow, S., \& Mwaura, S. (2017). Households as a site of entrepreneurial activity. Foundations and Trends in Entrepreneurship, 13(2), 81-190.

Carter, S., Mwaura, S., Ram, M., Trehan, K., \& Jones, T. (2015). Barriers to ethnic minority and women's enterprise: Existing evidence, policy tensions and unsettled questions. International Small Business Journal, 33(1), 49-69.

Carter, S., \& Ram, M. (2003). Reassessing portfolio entrepreneurship. Small Business Economics, 21(4), 371-380.

Carter, S., Tagg, S., \& Dimitratos, P. (2004). Beyond portfolio entrepreneurship: Multiple income sources in small firms. Entrepreneurship \& Regional Development, 16(6), 481-500.

Chowdhury, F., Audretsch, D. B., \& Belitski, M. (2019). Institutions and entrepreneurship quality. Entrepreneurship Theory and Practice, 43(1), 51-81.

Chowdhury, F., Terjesen, S., \& Audretsch, D. (2015). Varieties of entrepreneurship: Institutional drivers across entrepreneurial activity and country. European Journal of Law and Economics, 40(1), 121-148.

Clegg, S. (2010). The state, power, and agency: Missing in action in institutional theory? Journal of Management Inquiry, 19(1), 4-13.

Coleman, S. (2016). Gender, entrepreneurship, and firm performance: Recent research and considerations of context. In M. L. Connerley \& J. Wu (Eds.), Handbook on well-being of working women (pp. 375-391). Dordrecht: Springer.

Colli, A. (2012). Contextualizing performances of family firms: The perspective of business history. Family Business Review, 25(3), 243-257.

Cooper, A., Ramachandran, M., \& Schoorman, D. (1998). Time allocation patterns of craftsmen and administrative entrepreneurs: Implications for financial performance. Entrepreneurship Theory and Practice, 22(2), 123-136.

Das, T. K., \& Teng, B. S. (1998). Time and entrepreneurial risk behavior. Entrepreneurship Theory and Practice, 22(2), 69-88.

De Clercq, D., Danis, W. M., \& Dakhli, M. (2010). The moderating effect of institutional context on the relationship between associational activity and new business activity in emerging economies. International Business Review, 19(1), 85-101.

De Massis, A., Kotlar, J., Wright, M., \& Kellermanns, F. W. (2018). Sector-based entrepreneurial capabilities and the promise of sector studies in entrepreneurship. Entrepreneurship Theory and Practice, 42(1), 3-23.

Drakopoulou Dodd, S., Pret, T., \& Shaw, E. (2016). Advancing understanding of entrepreneurial embeddedness: Forms of capital, social contexts and time. In F. Welter \& W. B. Gartner (Eds.), A research agenda on entrepreneurship and context (pp. 120-133). Cheltenham: Edward Elgar.

Dubois, A. (2016). Transnationalising entrepreneurship in a peripheral region: The translocal embeddedness paradigm. Journal of Rural Studies, 46, 1-11. 
Elam, A., \& Terjesen, S. (2010). Gendered institutions and cross-national patterns of business creation for men and women. European Journal of Development Research, 22, 331-348.

Elfving, J., Brännback, M., \& Carsrud, A. (2009). Toward a contextual model of entrepreneurial intentions. In A. L. Carsrud \& M. Brännback (Eds.), Understanding the entrepreneurial mind: Opening the black box (pp. 23-33). New York, NY: Springer.

Elfving, J., Brännback, M., \& Carsrud, A. (2017). Revisiting a contextual model of entrepreneurial intentions. In M. Brännback \& A. L. Carsrud (Eds.), Revisiting the entrepreneurial mind: Inside the black box: An expanded edition (pp. 83-90). Cham: Springer.

Estrin, S., \& Mickiewicz, T. (2011). Institutions and female entrepreneurship. Small Business Economics, 37(4), 397-415.

Estrin, S., Mickiewicz, T., \& Stephan, U. (2013). Entrepreneurship, social capital, and institutions: Social and commercial entrepreneurship across nations. Entrepreneurship Theory and Practice, 37(3), 479-504.

Estrin, S., \& Prevezer, M. (2010). A survey on institutions and new firm entry: How and why do entry rates differ in emerging markets? Economic Systems, 34(3), 289-308.

Fadahunsi, A., \& Rosa, P. (2002). Entrepreneurship and illegality: Insights from the Nigerian cross-border trade. Journal of Business Venturing, 17(5), 397-429.

Fischer, E., Reuber, A. R., Hababou, M., Johnson, W., \& Lee, S. (1998). The role of socially constructed temporal perspectives in the emergence of rapid-growth firms. Entrepreneurship Theory and Practice, 22(2), 13-30.

Fitz-Koch, S., Nordqvist, M., Carter, S., \& Hunter, E. (2018). Entrepreneurship in the agricultural sector: A literature review and future research opportunities. Entrepreneurship Theory and Practice, 42(1), 129-166.

Fletcher, D., \& Selden, P. (2016). A relational conceptualization of context and the real-time emergence of entrepreneurship processes. In F. Welter \& W. B. Gartner (Eds.), A research agenda for entrepreneurship and context (pp. 79-92). Cheltenham: Edward Elgar.

Frederick, H. H. (2008). Introduction to special issue on indigenous entrepreneurs. Journal of Enterprising Communities, 2(3), 185-191.

Fritsch, M., Bublitz, E., Sorgner, A., \& Wyrwich, M. (2014). How much of a socialist legacy? The re-emergence of entrepreneurship in the East German transformation to a market economy. Small Business Economics, 43(2), 427-446.

Fritsch, M., Obschonka, M., \& Wyrwich, M. (2019). Historical roots of entrepreneurship-facilitating culture and innovation activity: An analysis for German regions. Regional Studies. online early. doi:10.1080/00343404.2019. 1580357

Fritsch, M., Sorgner, A., Wyrwich, M., \& Zazdravnykh, E. (2019). Historical shocks and persistence of economic activity: Evidence on self-employment from a unique natural experiment. Regional Studies, 53(6), 790-802.

Gartner, W. B. (2016). Narrating context. In F. Welter \& W. B. Gartner (Eds.), A research agenda for entrepreneurship and context (pp. 146-155). Cheltenham: Edward Elgar.

Godfrey, P. C., Hassard, J., O’Connor, E. S., Rowlinson, M., \& Ruef, M. (2016). What is organizational history? Toward a creative synthesis of history and organization studies. Academy of Management Review, 41(4), 590-608. 
Greenman, A. (2013). Everyday entrepreneurial action and cultural embeddedness: An institutional logics perspective. Entrepreneurship \& Regional Development, 25(7-8), 631-653.

Greve, A., \& Salaff, J. W. (2003). Social networks and entrepreneurship. Entrepreneurship Theory and Practice, 28(1), 1-22.

Griffin, M. A. (2007). Specifying organizational contexts: Systematic links between contexts and processes in organizational behavior. Journal of Organizational Behavior, 28(7), 859-863.

Gupta, V. K., Turban, D. B., \& Pareek, A. (2013). Differences between men and women in opportunity evaluation as a function of gender stereotypes and stereotype activation. Entrepreneurship Theory and Practice, 37(4), 771-788.

Hall, P. A., \& Thelen, K. (2009). Institutional change in varieties of capitalism. Socio-Economic Review, 7(1), 7-34.

Hansen, E. L., \& Bird, B. J. (1998). The stages model of high-tech venture founding: Tried but true? Entrepreneurship Theory and Practice, 22(2), 111-122.

Hechavarria, D. M., \& Reynolds, P. D. (2009). Cultural norms \& business startups: The impact of national values on opportunity and necessity entrepreneurs. International Entrepreneurship and Management Journal, 5(4), 417-437.

Henrekson, M. (2007). Entrepreneurship and institutions. Comparative Labor Law and Policy Journal, 28, 717-742.

Herrmann, A. M. (2019). A plea for varieties of entrepreneurship. Small Business Economics, 52(2), 331-343.

Hoang, H., \& Antoncic, B. (2003). Network-based research in entrepreneurship. Journal of Business Venturing, 18(2), 165-187.

Hoang, H., \& Yi, A. (2015). Network-based research in entrepreneurship: A decade in review. Foundations and Trends ${ }^{\circledR}$ in Entrepreneurship, 11(1), 1-54.

Hodges, N., Watchravesringkan, K., Yurchisin, J., Karpova, E., Marcketti, S., Hegland, J., ... Childs, M. (2015). Women and apparel entrepreneurship: An exploration of small business challenges and strategies in three countries. International Journal of Gender and Entrepreneurship, 7(2), 191-213.

Ingram, P., Rao, H., \& Silverman, B. S. (2012). History in strategy research: What, why, and how? In S. J. Kahl, B. S. Silverman, \& M. A. Cusumano (Eds.), History and strategy (pp. 241-273). Bingley: Emerald Group Publishing Limited.

Jack, S., Dodd, S. D., \& Anderson, A. R. (2008). Change and the development of entrepreneurial networks over time: A processual perspective. Entrepreneurship \& Regional Development, 20(2), 125-159.

Johannisson, B. (2009). Glocalization as a generic entrepreneurial strategy. In A. Lundström (Ed.), The role of SMEs and entrepreneurship in a globalised economy (pp. 41-58). Stockholm: The Globalisation Council.

Jones, G., \& Rose, M. B. (1993). Family capitalism. Business History, 35(4), $1-16$.

Jones, G., \& Wadhwani, R. D. (2006). Entrepreneurship and business history: Renewing the research agenda. Boston, MA: Division of Research, Harvard Business School.

Kasabov, E., \& Sundaram, U. (2014). Enterprising places as historical synergies: An institutional account of coventry through the middle ages. In L. Pugalis \& J. Liddle (Eds.), Enterprising places: Leadership and governance networks (pp. 29-53). Bingley: Emerald Group Publishing Limited. 
Katz, D., \& Kahn, R. L. (1978). The social psychology of organizations. New York, NY: John Wiley \& Sons.

Khavul, S., Bruton, G. D., \& Wood, E. (2009). Informal family business in Africa. Entrepreneurship Theory and Practice, 33(6), 1219-1238.

Kipping, M., \& Üsdiken, B. (2015). Turning how and where? In P. G. McLaren, A. J. Mills, \& T. G. Weatherbee (Eds.), The Routledge companion to management and organizational history (pp. 372-379). London: Routledge.

Kiviluoto, N. (2013). Growth as evidence of firm success: Myth or reality? Entrepreneurship \& Regional Development, 25(7-8), 569-586. doi:10.1080/0898 5626.2013.814716

Korsgaard, S., \& Anderson, A. R. (2011). Enacting entrepreneurship as social value creation. International Small Business Journal, 29(2), 135-151.

Korsgaard, S., Müller, S., \& Tanvig, H. W. (2015). Rural entrepreneurship or entrepreneurship in the rural: Between place and space. International Journal of Entrepreneurial Behavior \& Research, 21(1), 5-26.

Kwami, J. D. (2015). Gender, entrepreneurship, and informal markets in Africa: Understanding how Ghanaian women traders self-organize with digital tools. In J. Ofori-Dankwa \& K. Boasiako Omane-Antwi (Eds.), Comparative case studies on entrepreneurship in developed and developing countries (pp. 19-49). Hershey: IGI-Global.

Landström, H. (2015). Entrepreneurship research and its historical background. In T. Baker \& F. Welter (Eds.), The Routledge companion to entrepreneurship (pp. 21-40). London: Routledge.

Landström, H., \& Lohrke, F. (Eds.). (2010). Historical foundations of entrepreneurial research. Cheltenham: Edward Elgar.

Lang, R., Fink, M., \& Kibler, E. (2014). Understanding place-based entrepreneurship in rural Central Europe: A comparative institutional analysis. International Small Business Journal-Researching Entrepreneurship, 32(2), 204-227.

Leca, B., \& Naccache, P. (2006). A critical realist approach to institutional entrepreneurship. Organization, 13(5), 627-651.

Lechner, C., \& Dowling, M. (2003). Firm networks: External relationships as sources for the growth and competitiveness of entrepreneurial firms. Entrepreneurship \& Regional Development: An International Journal, 15(1), 1-26.

Ledeneva, A. V. (1998). Russia's economy of favours: Blat, networking, and informal exchange. New York, NY; Cambridge: Cambridge University Press.

Ledeneva, A. V. (2008). Blat and guanxi: Informal practices in Russia and China. Comparative Studies in Society and History, 50(01), 118-144.

Lee, C. K., \& Hung, S. C. (2014). Institutional entrepreneurship in the informal economy: China's shan-zhai mobile phones. Strategic Entrepreneurship Journal, 8(1), 16-36.

Lehmann, E. E., Schenkenhofer, J., \& Wirsching, K. (2019). Hidden champions and unicorns: A question of the context of human capital investment. Small Business Economics, 52(2), 359-374.

Lévesque, M., \& Maccrimmon, K. R. (1998). On the interaction of time and money invested in new ventures. Entrepreneurship Theory and Practice, 22(2), 89-110.

Levie, J., \& Lichtenstein, B. B. (2010). A terminal assessment of stages theory: Introducing a dynamic states approach to entrepreneurship. Entrepreneurship Theory and Practice, 34(2), 317-350. 


\section{Understanding Contexts and Entrepreneurship}

Lewellyn, K. B., \& Muller-Kahle, M. I. (2015). A configurational approach to understanding gender differences in entrepreneurial activity: A fuzzy set analysis of 40 countries. International Entrepreneurship and Management Journal, 12(3), 765-790.

Li, D. D., Feng, J., \& Jiang, H. (2006). Institutional entrepreneurs. The American Economic Review, 96(2), 358-362.

Lippmann, S., \& Aldrich, H. (2016a). A Rolling Stone gathers momentum: Generational units, collective memory, and entrepreneurship. Academy of Management Review, 41(4), 658-675.

Lippmann, S., \& Aldrich, H. (2016b). The temporal dimension of context. In F. Welter \& W. B. Gartner (Eds.), A research agenda for entrepreneurship and context (pp. 54-64). Cheltenham: Edward Elgar.

Low, M., \& MacMillan, I. (1988). Entrepreneurship: Past research and future challenges. Journal of Management, 14(2), 139-161.

Lubinski, C. (2011). Path dependency and governance in German family firms. Business History Review, 85(4), 699-724.

Manolova, T. S., \& Yan, A. (2002). Institutional constraints and entrepreneurial responses in a transforming economy: The case of Bulgaria. International Small Business Journal, 20(2), 163-184.

Mason, C., Reuschke, D., Syrett, S., \& van Ham, M. (Eds.). (2015). Entrepreneurship in cities: Neighbourhoods, households and homes. Cheltenham: Edward Elgar.

McCarthy, D. J., \& Puffer, S. M. (2016). Institutional voids in an emerging economy: From problem to opportunity. Journal of Leadership \& Organizational Studies, 23(2), 208-219.

McKelvie, A., Wiklund, J., \& Brattström, A. (2018). Externally acquired or internally generated? Knowledge development and perceived environmental dynamism in new venture innovation. Entrepreneurship Theory and Practice, 42(1), 24-46.

Micelotta, E., Washington, M., \& Docekalova, I. (2018). Industry gender imprinting and new venture creation: The liabilities of women's leagues in the sports industry. Entrepreneurship Theory and Practice, 42(1), 94-128.

Mwega, F. M. (1991). Informal entrepreneurship in an African urban area. Small Enterprise Development, 2(3), 33-37.

Naudé, W. A., \& Havenga, J. J. D. (2005). An overview of African entrepreneurship and small business research. Journal of Small Business \& Entrepreneurship, 18(1), 101-120.

Nee, V., \& Matthews, R. (1996). Market transition and societal transformation in reforming state socialism. Annual Review of Sociology, 22, 401-435.

Noguera, M., Alvarez, C., Merigó, J. M., \& Urbano, D. (2015). Determinants of female entrepreneurship in Spain: An institutional approach. Computational and Mathematical Organization Theory, 21(4), 341-355.

Ojo, S., Nwankwo, S., \& Gbadamosi, A. (2013). Ethnic entrepreneurship: The myths of informal and illegal enterprises in the UK. Entrepreneurship \& Regional Development, 25(7-8), 587-611.

Onoshchenko, O., \& Williams, C. C. (2013). Paying for favours: Evaluating the role of blat in post-soviet Ukraine. Debatte: Journal of Contemporary Central and Eastern Europe, 21(2-3), 259-277. 
Oughton, E., Wheelock, J., \& Baines, S. (2003). Micro-businesses and social inclusion in rural households: A comparative analysis. Sociologia Ruralis, 43(4), 331-348.

Pacheco, D. F., York, J. G., Dean, T. J., \& Sarasvathy, S. D. (2010). The coevolution of institutional entrepreneurship: A tale of two theories. Journal of Management, 36(4), 974-1010.

Pahnke, A., \& Welter, F. (2019). The German Mittelstand: Antithesis to Silicon Valley entrepreneurship? Small Business Economics, 52(2), 345-358.

Pathak, S., Golz, S., \& Buche, M. W. (2013). Influences of gendered institutions on women's entry into entrepreneurship. International Journal of Entrepreneurial Behaviour \& Research, 19(5), 478-502.

Puffer, S. M., McCarthy, D. J., \& Boisot, M. (2010). Entrepreneurship in Russia and China: The impact of formal institutional voids. Entrepreneurship Theory and Practice, 34(3), 441-467.

Radaelli, G., Dell'Era, C., Frattini, F., \& Messeni Petruzzelli, A. (2018). Entrepreneurship and human capital in professional sport: A longitudinal analysis of the Italian soccer league. Entrepreneurship Theory and Practice, 42(1), 70-93.

Ram, M., Jones, T., \& Villares-Varela, M. (2017). Migrant entrepreneurship: Reflections on research and practice. International Small Business JournalResearching Entrepreneurship, 35(1), 3-18.

Ramirez-Pasillas, M., Brundin, E., \& Markowska, M. (2017). Contextualizing entrepreneurship in-between. In M. Ramirez-Pasillas, E. Brundin, \& M. Markowska (Eds.), Contextualizing entrepreneurship in emerging economies and developing countries (pp. 1-17). Cheltenham: Edward Elgar.

Randerson, K., Bettinelli, C., Fayolle, A., \& Anderson, A. (2015). Family entrepreneurship as a field of research: Exploring its contours and contents. Journal of Family Business Strategy, 6(3), 143-154.

Rautiainen, M., Rosa, P., Pihkala, T., Parada, M. J., \& Discua Cruz, A. (Eds.). (2019). The family business group phenomenon. Cham: Springer.

Rehn, A., Brännback, M., Carsrud, A., \& Lindahl, M. (2013). Challenging the myths of entrepreneurship? Entrepreneurship \& Regional Development, 25(7-8), 543-551.

Renzulli, L. A., Aldrich, H., \& Moody, J. (2000). Family matters: Gender, networks, and entrepreneurial outcomes. Social Forces, 79(2), 523-546.

Rindova, V., Barry, D., \& Ketchen, D. J. (2009). Entrepreneuring as emancipation. Academy of Management Review, 34(3), 477-491.

Roberts, K., \& Zhou, C. (2000). New private enterprises in three transitional contexts: Central Europe, the former Soviet Union and China. Post-Communist Economies, 12(2), 187-199.

Robson, M. (2010). Explaining cross-national variations in entrepreneurship: The role of social protection and political culture. In A. Freytag \& R. Thurik (Eds.), Entrepreneurship and culture (pp. 245-267). Heidelberg: Springer.

Scott, L., Dolan, C., Johnstone-Louis, M., Sugden, K., \& Wu, M. (2012). Enterprise and inequality: A study of Avon in South Africa. Entrepreneurship Theory and Practice, 36(3), 543-568.

Scott, W. R. (1998). Organizations: Natural, rational and open systems. London: Prentice-Hall International. 


\section{Understanding Contexts and Entrepreneurship}

Semrau, T., \& Werner, A. (2014). How exactly do network relationships pay off? The effects of network size and relationship quality on access to start: Up resources. Entrepreneurship Theory and Practice, 38(3), 501-525.

Slevin, D. P., \& Covin, J. G. (1998). Time, growth, complexity, and transitions: Entrepreneurial challenges for the future. Entrepreneurship Theory and Practice, 22(2), 53-68.

Slotte-Kock, S., \& Coviello, N. (2010). Entrepreneurship research on network processes: A review and ways forward. Entrepreneurship Theory and Practice, 34(1), 31-57.

Smallbone, D., \& Welter, F. (2001). The distinctiveness of entrepreneurship in transition economies. Small Business Economics, 16(4), 249-262.

Smallbone, D., \& Welter, F. (2006). Conceptualising entrepreneurship in a transition context. International Journal of Entrepreneurship and Small Business, 3(2), 190-206.

Smallbone, D., \& Welter, F. (2009). Entrepreneurship and small business development in post-socialist economies. London: Routledge.

Smallbone, D., \& Welter, F. (2012). Entrepreneurship and institutional change in transition economies: The commonwealth of independent states, central and Eastern Europe and China compared. Entrepreneurship \& Regional Development, 24(3-4), 215-233.

Smallbone, D., Welter, F., \& Ateljevic, J. (2014). Entrepreneurship in emerging market economies: Contemporary issues and perspectives. International Small Business Journal, 32(2), 113-116.

Smallbone, D., Welter, F., \& Jianzhong, X. (2011). "From Mao to market: Entrepreneurs as institutional change agents in China." Paper presented at the ICSB World Conference, Washington, DC, United States.

Stenholm, P., Acs, Z. J., \& Wuebker, R. (2013). Exploring country-level institutional arrangements on the rate and type of entrepreneurial activity. Journal of Business Venturing, 28(1), 176-193.

Stephan, U., Uhlaner, L. M., \& Stride, C. (2015). Institutions and social entrepreneurship: The role of institutional voids, institutional support, and institutional configurations. Journal of International Business Studies, 46(3), 308-331.

Steyaert, C. (2016). After context. In F. Welter \& W. B. Gartner (Eds.), A research agenda for entrepreneurship and context (pp. 28-53). Cheltenham: Edward Elgar.

Steyaert, C., \& Katz, J. A. (2004). Reclaiming the space of entrepreneurship in society: Geographical, discursive and social, dimensions. Entrepreneurship \& Regional Development, 16(3), 179-196.

Su, J., Zhai, Q., \& Landström, H. (2015). Entrepreneurship research in China: Internationalization or contextualization? Entrepreneurship \& Regional Development, 27(1-2), 50-79.

Su, Z., Xie, E., \& Wang, D. (2015). Entrepreneurial orientation, managerial networking, and new venture performance in China. Journal of Small Business Management, 53(1), 228-248.

Tedmanson, D., Verduyn, K., Essers, C., \& Gartner, W. B. (2012). Critical perspectives in entrepreneurship research. Organization, 19(5), 531-541.

Thornton, P. H., Ribeiro-Soriano, D., \& Urbano, D. (2011). Socio-cultural factors and entrepreneurial activity: An overview. International Small Business Journal, 29(2), 105-118. 
Tolbert, P. S., David, R. J., \& Sine, W. D. (2011). Studying choice and change: The intersection of institutional theory and entrepreneurship research. Organization Science, 22(5), 1332-1344.

Tracey, P., Phillips, N., \& Jarvis, O. (2011). Bridging institutional entrepreneurship and the creation of new organizational forms: A multilevel model. Organization Science, 22(1), 60-80.

Ucbasaran, D., Westhead, P., \& Wright, M. (2001). The focus of entrepreneurial research: Contextual and process issues. Entrepreneurship Theory and Practice, 25(4), 57-80.

Urbano, D., \& Alvarez, C. (2014). Institutional dimensions and entrepreneurial activity: An international study. Small Business Economics, 42(4), 703-716.

van Gelderen, M., \& Masurel, E. (Eds.). (2012). Entrepreneurship in context. Abingdon: Routledge.

Van Ham, M., Reuschke, D., Kleinhans, R., Mason, C., \& Syrett, S. (Eds.). (2017). Entrepreneurial neighbourhoods: Towards an understanding of the economies of neighbourhoods and communities. Cheltenham: Edward Elgar.

van Stel, A., Storey, D., \& Thurik, A. (2007). The effect of business regulations on nascent and young business entrepreneurship. Small Business Economics, 28(2), 171-186.

Verduijn, K., \& Essers, C. (2013). Questioning dominant entrepreneurship assumptions: The case of female ethnic minority entrepreneurs. Entrepreneurship \& Regional Development, 25(7-8), 612-630.

Verduyn, P. D., Deirdre Tedmanson, Caroline Essers, K., Verduijn, K., Dey, P., Tedmanson, D., \& Essers, C. (2014). Emancipation and/or oppression? Conceptualizing dimensions of criticality in entrepreneurship studies. International Journal of Entrepreneurial Behavior \& Research, 20(2), 98-107.

von Briel, F., Davidsson, P., \& Recker, J. (2018). Digital technologies as external enablers of new venture creation in the IT hardware sector. Entrepreneurship Theory and Practice, 42(1), 47-69.

Wadhwani, R. D. (2016). Entrepreneurship in historical context: Using history to develop theory and understand process. In F. Welter \& W. B. Gartner (Eds.), A research agenda for entrepreneurship and context (pp. 65-78). Cheltenham: Edward Elgar.

Wang, Q. (2013). Constructing a multilevel spatial approach in ethnic entrepreneurship studies. International Journal of Entrepreneurial Behaviour \& Research, 19(1), 97-113.

Webb, J. W., Khoury, T. A., \& Hitt, M. A. (2019). The influence of formal and informal institutional voids on entrepreneurship. Entrepreneurship Theory and Practice. https://journals.sagepub.com/doi/full/10.1177/1042258719830310. Doi: $10.1177 / 1042258719830310$

Webb, J. W., Pryor, C. G., \& Kellermanns, F. W. (2015). Household enterprise in base-of-the-pyramid markets: The influence of institutions and family embeddedness. Africa Journal of Management, 1(2), 115-136.

Weik, E. (2011). Institutional entrepreneurship and agency. Journal for the Theory of Social Behaviour, 41(4), 466-481.

Welter, F. (2019). The power of words and images: Towards talking about and seeing entrepreneurship and innovation differently. In D. Audretsch, E. Lehmann, \& A. N. Link (Eds.), A research agenda for entrepreneurship and innovation (pp. 179-196). Cheltenham: Edward Elgar. 
Welter, F., Baker, T., Audretsch, D. B., \& Gartner, W. B. (2017). Everyday entrepreneurship: A call for entrepreneurship research to embrace entrepreneurial diversity. Entrepreneurship Theory and Practice, 41(3), 311-321.

Welter, F., \& Gartner, W. B. (2016). Advancing our research agenda for entrepreneurship and contexts. In F. Welter \& W. B. Gartner (Eds.), A research agenda on entrepreneurship and context (pp. 156-160). Cheltenham: Edward Elgar.

Welter, F., \& Smallbone, D. (2003). Entrepreneurship and enterprise strategies in transition economies: An institutional perspective. In D. Kirby \& A. Watson (Eds.), Small firms and economic development in developed and transition economies: A reader (pp. 95-114). Aldershot: Ashgate.

Welter, F., \& Smallbone, D. (2008). Women's entrepreneurship from an institutional perspective: The case of Uzbekistan. International Entrepreneurship and Management Journal, (4), 505-520.

Welter, F., \& Smallbone, D. (2010). The embeddedness of women's entrepreneurship in a transition context. In C. G. Brush, A. De Bruin, E. Gatewood, \& C. Henry (Eds.), Women entrepreneurs and the global environment for growth: A research perspective (pp. 96-117). Cheltenham; Northampton, MA: Edward Elgar.

Welter, F., \& Smallbone, D. (2011). Institutional perspectives on entrepreneurial behavior in challenging environments. Journal of Small Business Management, 49(1), 107-125.

Welter, F., \& Smallbone, D. (2012). Institutional perspectives on entrepreneurship. In D. Hjorth (Ed.), Organizational entrepreneurship handbook. Cheltenham: Edward Elgar.

Welter, F., \& Smallbone, D. (2015). Creative forces for entrepreneurship: The role of institutional change agents. Working Paper, 1-15. Bonn: IfM.

Welter, F., Smallbone, D., \& Pobol, A. (2015). Entrepreneurial activity in the informal economy: A missing piece of the entrepreneurship jigsaw puzzle. Entrepreneurship \& Regional Development, 27(5-6), 292-306.

Welter, F., Smallbone, D., Slonimski, A., Linchevskaya, O., Pobol, A., \& Slonimska, M. (2014). Enterprising families in a cross-border context: The example of Belarus. In M. T. T. Thai \& E. Turkina (Eds.), Internationalization of firms from economies in transition (pp. 276-302). Cheltenham: Edward Elgar.

Welter, F., Xheneti, M., \& Smallbone, D. (2018). Entrepreneurial resourcefulness in unstable institutional contexts: The example of European Union borderlands. Strategic Entrepreneurship Journal, 12(1), 23-53.

West, G. P., \& Meyer, G. D. (2017). Temporal dimensions of opportunistic change in technology-based ventures. Entrepreneurship Theory and Practice, 22(2), 31-52.

White, R. E., Hoskisson, R. E., Yiu, D. W., \& Bruton, G. D. (2008). Employment and market innovation in Chinese business group affiliated firms: The role of group control systems. Management and Organization Review, 4(2), 225-256.

Williams, C. C., \& Nadin, S. J. (2013). Beyond the entrepreneur as a heroic figurehead of capitalism: Re-representing the lived practices of entrepreneurs. Entrepreneurship \& Regional Development, 25(7-8), 552-568.

Williams, N., \& Vorley, T. (2015). Institutional asymmetry: How formal and informal institutions affect entrepreneurship in Bulgaria. International Small Business Journal, 33(8), 840-861. 
Wyrwich, M. (2013). Can socioeconomic heritage produce a lost generation with regard to entrepreneurship? Journal of Business Venturing, 28(5), 667-682.

Yang, K. M. (2004). Institutional holes and entrepreneurship in China. Sociological Review, 52(3), 371-389.

Yousafzai, S., Lindgreen, A., Saeed, S., Henry, C., \& Fayolle, A. (Eds.). (2018). Contextual embeddedness of women's entrepreneurship. London: Routledge.

Yousafzai, S. Y., Saeed, S., \& Muffatto, M. (2015). Institutional theory and contextual embeddedness of women's entrepreneurial leadership: Evidence from 92 countries. Journal of Small Business Management, 53(3), 587-604.

Zhou, M., Xu, T., \& Shenasi, S. (2016). Entrepreneurship and interracial dynamics: A case study of self-employed Africans and Chinese in Guangzhou, China. Ethnic and Racial Studies, 39(9), 1566-1586.

Zhou, Y., \& Teng, X. (2003). An innovative region in China: Interaction between multi-national corporations and local firms in a high-tech cluster in Beijing. Economic Geography, (79), 129-152. 


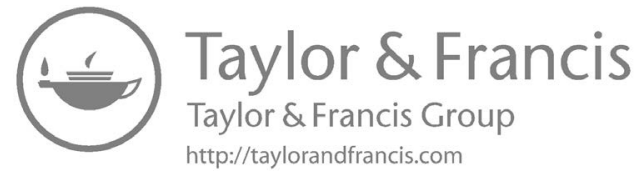




\section{Part II}

\section{Theorizing Contexts}




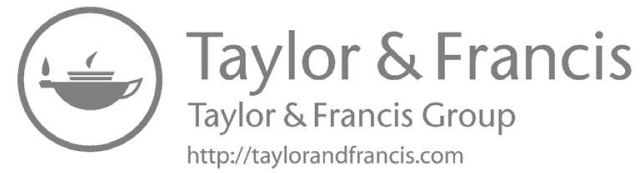




\section{Constructing Contexts Enacting, Talking, Seeing}

As a building block towards our Critical Process Approach, we now turn to how entrepreneurs "do contexts". We will discuss the construction of contexts in more detail, looking at enactment and the roles of language and imagery from a suggestively interdisciplinary perspective. The entrepreneurship field is a latecomer in this regard, moving in the wake of other disciplines with a long tradition of taking into consideration socially constructed contexts including, for example, artificial intelligence and computer sciences (Akman, 2000; Akman \& Bazzanella, 2003; Dourish, 2004; Edmonds \& Akman, 2002), linguistics (Bates, 1976; Labov, 1970), cognitive science (Chun \& Jiang, 1998; Perkins \& Salomon, 1989) and literary history (Felski, 2011), as well as, of course, anthropology (Boas, 1945). Our discussion of these topics is not intended or claimed to be comprehensive. Instead, the goal of this chapter is to illustrate these lenses and suggest their potential value: we wish to promote research that elaborates and challenges what we know, rather than to promote a specific research agenda. We will move towards formulating such an agenda in later chapters.

\section{Doing Context Through Enacting}

\section{How Contexts for Action Emerge}

In a manner analogous to West and Zimmerman's (1987) portrayal of people "doing gender" as an accomplishment, we view entrepreneurs as "doing contexts"; that is, they construct the contexts in which they operate as agentic responses to the environments they confront. As Baker and Welter (2017, p. 179) suggest, "Compared to monolithic conceptualizations of "the environment", the notions of context and doing context suggest multiplicity and the sorts of active agencies and ongoing social constructions and reconstructions that resonate with our deepest notions of entrepreneurship". The first sort of "doing context" we discuss here takes an "enactment" perspective towards understanding how contexts for action emerge from the environments in which entrepreneurs are embedded. 
As Baker and Nelson (2005, p. 331) argued, the environments in which entrepreneurs operate "have a stubborn facticity, either in the sense of an objective ecology of distributed resources or in the sense of appearing objective and being taken for granted by participants". The objective ecology is enormously important, as is made obvious by comparisons of entrepreneurship across geographies-for example, poor versus rich nations-or among members of structurally advantaged versus structurally disadvantaged demographic groups within nations (Baker, Gedajlovic, \& Lubatkin, 2005; Baker \& Powell, 2016; Welter \& Smallbone, 2009). Environments provide objective constraints and affordances and they also provide the backdrop in which enactment of context takes place. To a large extent, reified social constructions (Berger \& Luckmann, 1966) - those that are taken for granted as normal and naturalhave the same objectivity in determining entrepreneurs' behavior as does the objective resource ecology in which they are embedded.

Consistent with this perspective, the bulk of entrepreneurship-when defined as the founding of new organizations-is often portrayed as straightforward replication of those that already exist (Aldrich \& Ruef, 2006; DiMaggio \& Powell, 1983; Hannan \& Freeman, 1977). Baseline expectations for processes of enactment, building on Weick's (1979) observations regarding how actors typically refuse or otherwise fail to test cultural and institutional limitations, are consistent with such expectations of isomorphism: similar environments produce largely similar organizations. Against this backdrop, however, entrepreneurship research has also sometimes used an "enactment" lens to help explain how objectively similar environments may result in striking different contexts for entrepreneurial action and thereby organizational heterogeneity. These approaches illuminate how entrepreneurs may construct and define the contexts in which they operate by refusing to enact limitations that others take for granted or by selective enactment of some but not other elements of their environments.

Using Weick's (1979) imagery to build tension in their argument, Baker and Nelson (2005) defined "entrepreneurial bricolage" in part by a refusal to enact limitations. Entrepreneurs engaged in bricolage exhibited a bias for action that involved testing institutional and cultural definitions of what constitutes an appropriate resource or combination of resources. Compared to other entrepreneurs operating under similar objective constraints, those engaged in bricolage enacted more munificent contexts by seeing and acting upon combinations of inputs that were available cheaply or for free but which were not seen or acted upon as useful resources by the others. This study has helped to consolidate earlier work and promote additional research investigating how entrepreneurs make do by "applying combinations of the resources at hand to new problems and opportunities". For example, one popular stream of research explores how entrepreneurs do context as various forms of "resourcefulness", examining strategic behavior and actions such as bricolage in 
resource-scarce environments (e.g., Baker \& Nelson, 2005; Corbett \& Katz, 2013; Misra \& Kumar, 2000; Smallbone \& Welter, 2001; Welter \& Smallbone, 2011; Welter \& Xheneti, 2013; Welter et al., 2018).

In their study of textile and apparel entrepreneurs in the southeastern U.S., Powell and Baker (2014, p. 1418) developed a theory to explain how entrepreneurs facing "objectively similar adversity" enacted "distinctively different definitions of the adversity". This enactment took place through processes of 'bracketing' (Weick, Sutcliffe, \& Obstfeld, 2005), in which the definition of the situation was constructed by attending selectively to and acting upon some features of the environment while downplaying or ignoring others. This enacted definition of the situation became the pertinent context shaping the entrepreneurs' behavioral responses, with some defining the adversity as an "opportunity to embrace", some as a "challenge to counter", and some as a "threat to accommodate" (Powell \& Baker, 2014, pp. 1419-1420). In a subsequent study of the formation of nascent ventures pursuing community revitalization, Powell and Baker (2017) similarly found that differences in how the founding teams' members' "action-oriented bracketing" enacted the communities they were attempting to serve as either "connected to us" or "similar to us". Enacting this distinction created the contexts that shaped organizing processes, the structuring of the nascent organizations and outcomes that included whether founders remained engaged and whether the ventures persisted or disbanded. This paper expands our understanding of enactment as individual agency towards groups "doing context". Those founding teams that were unable to enact the community consistently either connected or engaged separately in destructive contestation and disbanded.

Most recently, Powell, Hamann, Bitzer, and Baker (2018) found that similar patterns of enactment through bracketing helped to explain different patterns of behavior and outcomes in South African cross-sector partnerships. Each of these nascent organizations included participants with deeply conflicting material interests. Those partnerships that actively surfaced and attended to the material conflicts among them were able to engage in collective prosocial efforts as intended. Those that bracketed out and failed to enact these conflicts were unable to engage in such collective efforts. Similar to the founding teams in the earlier study, those cross-sector partnerships that enacted a context of material conflict were able to generate collective efforts, while those that failed to enact material conflict as part of the context of their actions sputtered.

\section{Other Forms of Enacting Contexts}

While the studies presented previously understand and develop enactment specifically as a form of entrepreneurs' action-oriented bracketing (Weick et al., 2005), other research has explored the enactment of contexts in a more generic sense but still supporting the notion that entrepreneurs 
actively construct their contexts from the objective-sometime multipleenvironments available to them. For example, work on what has been labeled "entrepreneuring" similarly adopts a process perspective on entrepreneurial actions and sees the entrepreneurs as active constructors of the contexts in which they operate (Johannisson, 2011; Steyaert, Hjorth, \& Gartner, 2011). In rural areas, Gaddefors and Anderson (2019, p. 1) suggest that entrepreneurship is sometimes "about engagement with contexts rather than simply within a context", concluding that a closer understanding of entrepreneurial change making in rural areas can further our understanding of the entrepreneurial process as such. Studies of resource-depleted and peripheral regions (e.g., Johnstone \& Lionais, 2004; Korsgaard, Ferguson, \& Gaddefors, 2015; McKeever, Jack, \& Anderson, 2015; Müller \& Korsgaard, 2018), of community entrepreneurship (e.g., Gaddefors \& Anderson, 2017; Gaddefors \& Cronsell, 2009; Johannisson, 1990; Johannisson \& Nilsson, 1989; Peredo \& Chrisman, 2006, 2017) and of neighborhoods and cities (Mason, Reuschke, Syrett, \& van Ham, 2015; Van Ham, Reuschke, Kleinhans, Mason, \& Syrett, 2017) all highlight the agency of entrepreneurs in constructing contexts from their spatial and other environments. The entrepreneurs also creatively draw on the spatial resources available, thus contributing to changing their spatial contexts over time and creating new business opportunities for themselves and others (Müller \& Korsgaard, 2018). Entrepreneurs also contribute to creating or changing place identities: McKeever et al. (2015) show entrepreneurs drawing on their social bonds and their affinity to community, to achieve a positive identity of their place.

Research on entrepreneurial agency within institutional contexts has complemented its focus on interactions of regulatory and normative institutions with a growing emphasis on how entrepreneurs contribute to changing both regulatory and normative institutions instead of taking them as a given. Studies look into how entrepreneurs deal with often unstable and turbulent, institutional contexts and exploit so-called institutional voids (e.g., Mair \& Marti, 2009; Manolova \& Yan, 2002; McCarthy \& Puffer, 2016; Puffer, McCarthy, \& Boisot, 2010; Smallbone \& Welter, 2001; Tracey \& Phillips, 2011; Welter \& Smallbone, 2011), the strategies they apply to achieve legitimacy (Fisher, Kuratko, Bloodgood, \& Hornsby, 2017) and how they shape their institutional contexts in emerging industries such as the sharing economy (Uzunca, Rigtering, \& Ozcan, 2018).

Several studies have looked at the strategies of informal entrepreneurs (e.g., De Castro, Khavul, \& Bruton, 2014; Han, Nelen, \& Kang, 2015; Sutter, Webb, Kistruck, \& Bailey, 2013; Webb, Ireland, \& Ketchen, 2014; Welter \& Xheneti, 2015; Williams \& Nadin, 2013; Williams \& Shahid, 2014), showing the creativity and resourcefulness of individuals in defying and manipulating institutions. For example, Welter, Xheneti, and Smallbone (2018) illustrate that in unstable institutional contexts such as borderlands of countries in transition to market economies, the 
resourcefulness of the individuals involved in informal cross-border trade relies on continuity, reflected in previous skills and networks, family and friends or common cultural understandings, in order to generate the change that occurs when individuals challenge the new border regulations. Research in highly stratified settings such as Guatemala (Sutter et al., 2013) and South Africa (Powell et al., 2018) has begun to identify specific approaches that may be more effective than others in the face of extreme inequality in material resources and power.

Work on gender in entrepreneurship often takes a broad enactment perspective, illustrating how women challenge gender-averse institutions by enacting their business, institutional and spatial contexts. This is a recurrent theme in research on women's entrepreneurship (see the literature mentioned in Baker \& Welter, 2017). A recently published special issue of the journal Entrepreneurship \& Regional Development (Yousafzai, Fayolle, Saeed, Henry, \& Lindgreen, 2019) illustrates the variety of cultural and political environments women entrepreneurs enact and the manifold ways they move between, negotiate and reconcile or defy the demands of public and private contexts. Studying the cognitive antecedents of women entrepreneurs' sectoral choices in the U.S., Wieland, Kemmelmeier, Gupta, and McKelvey (2019, p. 178) provide compelling evidence that gendered cognitions affect entrepreneurial preferences, showing how they act as barriers and nudge "women into lower-return ventures in less lucrative industries". Cultural and cognitive institutions can also act as barriers to women's entrepreneurship in situations where industries or concepts such as technology and even entrepreneurship are portrayed as masculine (Wheadon \& Duval-Couetil, 2019).

The agency of women becomes even more visible if we turn to unfamiliar-to us-cultural contexts such as those pointed to by Welter (2011) in explaining her use of examples from former Soviet countries. In countries undergoing political and economic system changes such as former socialist countries in Central and Eastern Europe and Central Asia, some women entrepreneurs openly defy societal norms ascribing traditional gender roles, and some also turn gender stereotypes into a forum for creative play (Welter \& Smallbone, 2010), opposing and re-interpreting the predominant male image of entrepreneurship as shown by Bruno (1997, pp. 63-64). Similarly, the special issue noted in the previous paragraph assembles a number articles on women's entrepreneurship in-to us-non-familiar cultural and institutional contexts (Yousafzai et al., 2019). For example, women entrepreneurs in the migrant economy used their transnational journeys as contextual resource to enact gender through entrepreneurship, variously liberating themselves from patriarchal structures, reconfiguring gender and achieving upward mobility, defending gender equality and diversity or, in some cases, re-establishing their prior social status and complying with known gender relations from their country of origin 
(Villares-Varela \& Essers, 2019). Among women entrepreneurs operating informally in Nepal, Xheneti, Karki, and Madden (2019) take a closer look at the process of negotiating business and family demands, showing how the women do context at the business-family interface in order to simultaneously legitimize their entrepreneurial activities and to mobilize support, respond to society and family demands and find personal satisfaction. Similarly, studies of Arab women entrepreneurs show the complexities and intricacies of simultaneously "doing gender" and "doing context" to achieve career success in Lebanon (Tlaiss, 2019) and they illustrate the creative but "'hidden' entrepreneurial enactment" of displaced Palestinian women entrepreneurs operating in Jordan (Al-Dajani, Akbar, Carter, \& Shaw, 2019, p. 209). Other research highlights that women facing resource constraints are sometimes "even" capable of enacting contexts that support "slow" high-growth paths that look very different from what we expect (Ngoasong \& Kimbu, 2019). This and similar work celebrate the agency of socially excluded, marginalized and silenced groups, showing the value of critical perspectives on studying (women's) entrepreneurship by those our research too often renders ignored and silenced.

Research that has turned to studying entrepreneurship in relation to extreme contexts such as war and conflict (e.g., Bullough, Renko, \& Myatt, 2014; Langevang \& Namatovu, 2019) or environmental threats and natural disasters (e.g., Muñoz, Kimmitt, Kibler, \& Farny, 2019; Nelson \& Lima, 2019; Shepherd \& Williams, 2014; Williams \& Shepherd, 2016a, 2016b), shows that even in very difficult situations, entrepreneurs have much greater possibilities for agency than is oftentimes assumed. For example, entrepreneurial bricolage has been shown to play a "crucial role in enabling entrepreneurial individuals amongst a displaced population facing severe resource constraints to start up a business in the host location" (Kwong, Cheung, Manzoor, \& Rashid, 2019, p. 19). The same study also adds to understanding network bricolage in a displacement setting: the authors illustrate how the internally displaced entrepreneurs in Pakistan drew on clandestine networks to access resources, which helped create a "parallel system" (reminiscent of the parallel circuits in Soviet times) that, while favorable to the entrepreneurial ventures of the displaced persons, prevented their integration into the host communities. Obviously, many entrepreneurs keep some of their attachment to home places and countries. High place attachment can also spur on entrepreneurial agency in post-disaster situations (Grube \& Storr, 2018). In extreme contexts characterized by asymmetrical power relations, as in the West Bank, where Palestinian population has to "make do" with the constraints in an occupied territory, Palestinian entrepreneurs show another facet of doing context: for them, surviving as entrepreneurs is an "act of resistance" and a way to reclaim their humanity and "simply to achieve a semblance of normality is to struggle for equity and justice" (Alvi, Prasad, \& Segarra, 2019, p. 290). 


\section{Enactment Matters}

We theorize entrepreneurs "doing contexts" very broadly as a foundation for useful explanations of entrepreneurial agency and heterogeneity in the face of similar objective constraints and affordances. In simplest terms, environments become contexts for entrepreneurship through founders' choices and actions. In the preceding sections we have focused on processes of doing contexts by "enacting" them. We drew both on studies that invoke enactment in terms of specific theoretical mechanisms (Weick et al., 2005) and those that describe behaviors we categorize as involving enactment in more generic ways. In the next sections, we explore entrepreneurs doing contexts in other ways.

\section{Doing Context Through Talking}

\section{How Language Forms Contexts}

The action-oriented enactments of entrepreneurs (and researchers-see the next chapter) are one means through which contexts are constructed, but other cognitive processes and the ways we express them through language also shape contexts. First and foremost, we need to consider "how we understand context" (Brännback \& Carsrud, 2016, p. 18), which is not possible without taking into account the underlying cognitive processes. Cognitions are socially situated; they are not disembodied and abstract (Merleau-Ponty, 1964). A few conceptual studies in entrepreneurship have started to characterize the complex relations between cognitions and contexts (e.g., Brännback \& Carsrud, 2016; Chlosta \& Welter, 2017; Elfving et al., 2009, 2017). Research also has drawn our attention to the impact on opportunity recognition and exploitation of interactions between cognitions, social and institutional contexts (Fletcher, 2006; Jack \& Anderson, 2002; Koning, 2003), emphasizing that cognitions, interpretations and entrepreneurial behavior are linked (Gartner \& Carter, 2003). Language shapes entrepreneurial cognitions and vice versa, as has been described by Clarke and Cornelissen (2014, p. 387), drawing on classic arguments from anthropology and linguistics (see Whorf, 1956): "Language is not just a code for communication or simply an outward representation of thought, but is inseparably involved with processes of thinking and reasoning (...)" The authors understand language as having a central and "formative role in the construction of meaning" (p. 384), because language is the link between our internal sense-making, social sense giving and a means to convey meaning to others.

Related research from a variety of disciplines points us to the duality of context and language as well as allows deeper insights into how we do contexts: language simultaneously shapes and is shaped by contexts; it is 
a fundamental means through which actors do contexts. Borrowing from literary theory, Akman (2000, p. 743) suggests rethinking "contexts as social constructs" that arise from interpretations, seeing this as one possibility to further research on artificial intelligence that had initially applied a rather straightforward understanding of contexts as formal and-to some extent-computable environmental features. Synthesizing language studies, he points out that the context of any conversation and discussion matters for how we make sense and meaning of it. Often we will not be able to make sense out of, for example, an ongoing meeting to which we have arrived late-the conversation held cannot be understood independently from its contexts. Spatial, temporal and social contexts matter in this regard: where does the conversation take place? How much time has passed before we entered the conversation? Which social context do we enter, and to which power constellations do we attend? This interdependency of contexts and language is made visible in concepts of socially embedded speech and discourse, or, as Hymes (1974) phrased it, in studying the ethnography of communication. Hymes (1974) developed a model, SPEAKING, that makes central the contexts of discourses and the interactions of language with social life: $\mathrm{S}$ for setting (temporal and spatial contexts) and scene (psychological setting, culturally defined scene); $\mathrm{P}$ for participants (who context); E for ends (purpose of the discourse); A for act sequence (series of speech events); K for key (cues establishing the social context); I for instrumentalities (forms and styles of speech); $\mathrm{N}$ for norms (socio-institutional context); $\mathrm{G}$ for genre (speech categoriese.g., poem, lecture, and so on).

Language, reflected in speech, discourses and narratives, operates on all of the where and when context levels that Welter (2011) identified. As soon as we accept language as a way to contextualize, we move even further towards an active notion of doing context, where language contributes "in essential ways to the construction of context" (Auer, 1995, p. 20), implying that context is not given but the outcome of joint efforts by all participating in that particular place and time. Applying this perspective to our argument of "doing contexts" as critical, language is a primary means by which we express cognitions, and doing contexts, in this sense, comes via sharing our thinking and thoughts. Verbal and nonverbal language are jointly powerful. Words frame and have impact on the ways we construct and understand our world through talking about it (Welter, 2019). They are "windows for seeing what was earlier hidden or missing" (Gartner, 1993, p. 238), and "lead to deeds" (Gartner, 1993). In an early study on the power of words, Gartner (1990) explored the very different meanings researchers and practitioners attached to "entrepreneurship", concluding that language and ways of talking matter because we bring our own beliefs to these conversations: "Only by making explicit what we believe can we begin to understand how all of these different parts make up a whole" (Gartner, 1990, p. 28). Surprisingly, 
his idea of a closer look at the words we use to talk about entrepreneurship seems to have been forgotten for a long while. Only recently has entrepreneurship research begun to rediscover and broaden the role of language in our understanding of contextualizing entrepreneurship.

\section{How Language is Used in Entrepreneurship (Research)}

The linguistic turn in entrepreneurship research makes us aware of differences in how entrepreneurs perceive and act on their contexts through language. Verbal and non-verbal cues within conversations play a role, as they are interpreted by those present (Gumperz, 1992). Such cues are important because they frame a conversation and help individuals in making sense of and interpreting what is said and what is not said. In a conversation, individuals not only use but also negotiate cues, thus affecting changes in the framing of situations (Akman, 2000). They do context through speaking to and interacting with each other. Individually and socially, such communication, whether expressed verbally or through nonverbal signs, allows us to interact and make sense out of what happens around us. Thus, the language we use constructs our world (Garfinkel, 1967; Mehan \& Wood, 1975), including the places in which entrepreneurship happens. Tuan (1991) suggests that written and spoken words, such as the naming of a place, can render formerly invisible objects visible. Moreover, the grammar of a language highlights different aspects of a place; the kinds of words and the tone of voice, as well as the emotions underlying the conversation, also contribute to "making" the place. As Tuan (1991, p. 684) explains: "Thus, warm conversation between friends can make the place itself seem warm; by contrast, malicious speech has the power to destroy a place's reputation and thereby its visibility".

Entrepreneurship scholars have studied various aspects of language, first more implicitly through a focus on the narratives, stories and discourses that shape contexts for entrepreneurship and which themselves reflect language and linguistic patterns. More recently they have done so with increasing awareness of its role in constructing entrepreneurship contexts. For example, research has analyzed the role narratives play in the creation of entrepreneurial identities (Foss, 2004) and in creating legitimacy in a new venture (O'Connor, 2004). Recent studies have looked into the impact of language on resource access (e.g., Balachandra, Briggs, Eddleston, \& Brush, 2017; Gorbatai \& Nelson, 2015; Kanze, Huang, Conley, \& Higgins, 2018; Malmström, Johansson, \& Wincent, 2017), thereby emphasizing how language influences social and business contexts. For example, Parhankangas and Renko (2017) analyzed video pitches of commercial and social entrepreneurs on crowdfunding platforms in order to understand whether and how the language entrepreneurs used to pitch their ventures would influence their access to funding. They found that social and commercial entrepreneurs differed widely in 


\section{0}

the linguistic styles they used and were expected to use to pitch for crowdfunding. Their results emphasize the importance of expectations of suitable language in creating and reinforcing differences in entrepreneurship.

Moss, Renko, Block, and Meyskens (2018) studied the narrative presentations of pro-social ventures on crowdfunding platforms, showing that potential funders were quick to relate to social descriptions in their funding decisions, although most ventures presented both social and economic messages. The authors conclude that words matter beyond narratives as "sets of prototypical linguistic features that allow any outsiders to act in reference to the venture" (Moss et al., 2018, p. 655), pointing to the difficulty if language transports multiple meanings-as in this case, both social and economic messages. Along similar lines, research has identified contextualized understandings of key entrepreneurship concepts that differ fundamentally between communities, as has been shown by Achtenhagen, Naldi, and Melin (2010) in their study on business growth and its interpretation by practitioners and entrepreneurship scholars.

Researchers have also looked into the role of discourses in shaping and changing contexts for entrepreneurship and their role in constructing institutional and spatial contexts (for an in-depth review of related studies, see: Welter, 2019). For example, in their study of social entrepreneurship in the U.K., Parkinson and Howorth (2008) attempted to understand the interplay between the grand discourse of enterprise and the individual narratives of social entrepreneurs. Their results illustrate how social entrepreneurs construct their discourse and legitimacy in contrast to the standard entrepreneurship discourse, seeing themselves first as activists with a social goal and then as entrepreneurs who need to make some profit or earn money. The authors conclude that entrepreneurs may appropriate or re-write the overarching discourse on social entrepreneurship if the public rhetoric of (social) entrepreneurship differs from the lived experiences of social entrepreneurs.

Research on entrepreneurship and deprived communities has highlighted the role of language in constructing positive or negative images of spatial contexts (Parkinson, Howorth, \& Southern, 2017). Other research has critically questioned the construction of publicly accepted norms for entrepreneurship, pointing to the role of language through the stories told or used. For example, Smith (2010) shows masculine (and discriminatory) entrepreneurial identities to be reproduced in and produced through popular narratives such as the novel Cityboy on stock traders and analysts, later extending his analysis to the so-called "Essex Boys", demonstrating identity construction as a complex narrative and semiotic process that involves doing contexts at spatial, social and institutional levels (Smith, 2013). Kjellander, Nordqvist, and Welter (2012) discuss the situated, conflicted and gendered identity work of a female head of family business in a popular Swedish novel from the early 20th century. Markowska and Welter (2018) identify three typical identity narratives 
famous chef entrepreneurs use to justify their career choices-confirming that entrepreneurs in their narratives pick up social stereotypes of "this has been what I always wanted to do" (the dream follower), "I have been lucky" (serendipitous craftsman) and "I wanted to be famous in traditional businesses but-" (forced opportunist).

Metaphors are another linguistic means to construct the contexts in which entrepreneurs operate, and they are helpful both in illustrating the complexity of a phenomenon and in theory building (Weick, 1989). Metaphors have been widely studied in the management discipline (e.g., Cornelissen, 2006; Cornelissen, 2005; Dror \& Fabrizio, 2010; Ketokivi, Mantere, \& Cornelissen, 2017) and in entrepreneurship research (e.g., Drakopoulou Dodd, Pret, \& Shaw, 2016; Hyrsky, 1998; Lundmark \& Westelius, 2014; Maclean, Harvey, Gordon, \& Shaw, 2015). Metaphors "capture central, but varying and sometimes contradictory, thought patterns in the mainstream entrepreneurship literature" (Lundmark, Krzeminska, \& Shepherd, 2019, p. 153), but also are a means through which entrepreneurs make sense of their world. Research studying the metaphors entrepreneurs use shows, unsurprisingly, that they draw on societally accepted narratives in grounding their business in context. Entrepreneurs use metaphors to articulate their personal goals such as independence and goals that evoke public, social and moral concerns, thus positioning themselves positively towards their respective institutional and social contexts (Clarke \& Holt, 2010). Entrepreneurs also draw on metaphors to create legitimacy for their idea for a venture or new business. Other studies have shown cultural differences in the use of metaphors, such as the Wild West metaphor for entrepreneurship in the U.S. and the use of metaphors describing aggressive and competitive behaviors from team sports and military (De Koning \& Drakopoulou-Dodd, 2002); the application of parenthood or life cycle metaphors when discussing new venture creation, growth and failure (Cardon, Zietsma, Saparito, Matherne, \& Davis, 2005) or types of innovation (Bruni, Bonesso, \& Gerli, 2019).

Gaddefors (2007, p. 180) suggested early on that entrepreneurship scholars should pay attention to the role metaphors play in the construction "of an environment to act on". As Welter (2019) discusses, several studies have critically analyzed and questioned the myth-making role of verbal and non-verbal language for entrepreneurship reflected, for example, in the persistent notion of the entrepreneur as hero (Gartner, 1988; Ogbor, 2000; Warren, 2005), sometimes portrayed through mythical "aggressive, magical, giant, and religious imagery" (Nicholson \& Anderson, 2005). Also, places are elevated to myths, as has happened with Silicon Valley, which now is understood as the mythical place where high-growth and technology-oriented world-class entrepreneurship repeatedly emerges. Some research has shown how in peripheral places, entrepreneurs relate to such myths in their discourses about entrepreneurship, trying simultaneously to distinguish themselves from the myth 


\section{2}

and appropriate it (Gill \& Larson, 2014). Other research has illustrated how discourses or newspaper stories have assisted in mythicizing entrepreneurship as salvation for deprived and victimized cities or communities (e.g., Gregory, 2012; Johnstone \& Lionais, 2004). On a more hopeful note, Lundmark et al. (2019) conclude that root metaphors can be used to change prevailing discourses.

Language also plays a role in the gendering of social, institutional and spatial contexts. Kanze et al. (2018) show that investors tend to favor men by asking them questions that are focused on promotion (i.e., positively framed) and disfavor women by asking them questions that are focused on prevention (i.e., negatively framed), which triggers entrepreneurs to react with matching responses. Hechavarría, Terjesen, Stenholm, Brännback, and Lång (2018) take a closer look at gendered linguistic systems at a cross-national level and examine the impact this has on the persistent gender gap in early stage entrepreneurial activity. Countries with a sex-based language system and gender-differentiated pronouns experience a greater gender gap in entrepreneurship, suggesting that gender stereotypes appear to be reinforced by gendered linguistic structures, which discourages women from entrepreneurship. Their findings also illustrate how language reflects prejudgments in our behavior-in this case the gendered way language is used may signal stereotypes regarding women.

Women entrepreneurs may suffer from discriminatory verbal and nonverbal language, even if it is not intended to do so, language may nonetheless favor the emergence and persistence of gendered contexts. This has been illustrated by studies analyzing the media representation of women's entrepreneurship. Smith (2009) describes the "[d]iva" stereotype as a common biographical and media narrative for successful women entrepreneurs in the U.K., pointing out the "influence of journalistic licence" and the "power of male dominated journalistic practices to vilify enterprising behaviour to sell newspapers" (Smith, 2009, p. 160). Similarly, Achtenhagen and Welter (2011) demonstrate how verbal imagery is used to emphasize women in their traditional roles as housewives and mothers first, entrepreneurs second. Sometimes, the language used to describe women entrepreneurs emphasizes their good looks and sexuality, while men entrepreneurs are described using war-like metaphors. Byrne, Fattoum, and Diaz Garcia (2019) show how female entrepreneurial role models continue to present themselves as aligned to societal expectations: their dominant narrative emphasizes them as "superwomen" capable of doing it all and reconciling business with family. Although the authors distilled a few other narratives, these did not diverge (much) from what society expects of entrepreneurs and entrepreneurship more generally, instead reinforcing dominant images such as "everyone can do entrepreneurship" and "entrepreneurship is fun" (funpreneur), but also tapping into gendered stereotypes such as "entrepreneurship is a good way to combine family and work" (mumpreneurs) or "non-preneurs", who seemed to 
express excessive femininity reflected in being too caring or too trusting. Stereotypical representations of women entrepreneurs also extend to visual media such as television. Wheadon and Duval-Couetil (2018) examine the presentation of women's entrepreneurship in the reality show "Shark Tank", illustrating how the content, the social interactions and the ways of communication between the "sharks" (potential investors) and the entrepreneurs constructs and reinforces gendered stereotypes.

Recent studies add a micro perspective to the role of language in entrepreneurship, showing how entrepreneurs use rhetoric (Daly \& Davy, 2016; van Werven, Bouwmeester, \& Cornelissen, 2019) and arguments (Ruebottom, 2013; van Werven, Bouwmeester, \& Cornelissen, 2015) as another means of doing their contexts linguistically. Van Werven et al. (2019) analyzed the pitch narratives of entrepreneurs in an incubator, distilling four rhetorical strategies entrepreneurs drew on to construct plausible narratives that resonated with their stakeholders: they used enthymemes in discussing the future of the venture; talked "as if" the venture's future is now; made explicit claims about the current state of products/markets and developed their arguments through relying on historical and current data.

\section{Language Matters}

We have now described two inter-related processes of doing context: enactment and "talking" (which we construed broadly to encompass much verbal and non-verbal communication). The many disciplines involved in language and communications studies are rich and diverse and all we have tried to do here is to point towards some of the useful ways in which entrepreneurship scholars have brought to our attention the important of language use in constructing contexts. There is obviously vastly more interesting and useful work that can be done along these lines. Equally obvious is that the processes of enactment we described in the first section involve a lot of "talking". In addition, both enactment and talking are deeply intertwined with "seeing", which we explore next.

\section{Doing Context Through Seeing}

\section{How Seeing Shapes Contexts}

Although language and seeing are in many ways inextricably intertwined, for the sake of the illustrative exploration of these themes, we have separated them here. It is to the role of seeing in constructing contexts that we now turn, but one might argue that we should have discussed seeing first. John Berger (2008, p. 7) argued that: "Seeing comes before words. The child looks and recognizes before it can speak. But there is also another sense in which seeing comes before words. It is seeing which establishes 
our place in the surrounding world; we explain that world with words, but words can never undo the fact that we are surrounded by it. The relation between what we see and what we know is never settled". Although seeing is first of all a biological and neurological function of our bodies and brains, we also learn to see. For example, understanding photographs is about "learning to see" (Langmann \& Pick, 2018, p. 2); and our contexts shape how we see in more ways than we are aware of.

Sight and vision play an important role in constructing contexts and meaning in our worlds (Grady, 1996). Seeing is not simply a mechanical reaction to an external stimuli or of unconscious processes but also a result of our conscious and motivated decisions about what to look at, as our seeing constructs the world around us: "We only see what we look at. To look is an act of choice. (...) We never look at just one thing; we are always looking at the relation between things and ourselves. Our vision is continually active (. . .) constituting what is present to us as we are" (Berger, 2008, p. 8). We contextualize when we look at our world, because what we see depends on our socialization, our experiences and knowledge, on our background. When we see a photograph or a painting, what we see and the way we look at these images is shaped by assumptions: assumptions about beauty, race, status, etc. (Berger, 2008). Also, contexts help us in identifying what we see-in other words, we see in context, as visual objects normally occur in typical contexts, together with related ones: "Think of a giraffe, a basketball or a microscope. It is hard to imagine seeing any of them without a background and other objects. Our experience with the visual world dictates our predictions about what other objects to expect in a scene (. . .)" (Bar, 2004, p. 617). Such neurological research shows that we have difficulty recognizing many objects that are taken out of context, but can recognize similar objects if these are seen together (Bar, 2004).

Much of what we know about the social construction of meaning in photography can help to inform our understanding of seeing more generally and in its role in constructing contexts for entrepreneurship. Whenever we view a photograph, we actively construct meaning; we do not passively receive an "unmediated and unbiased visual report" (Schwartz, 1989 , p. 120). Viewers play a fundamental role in "constructing photographic meaning" and there is a "dynamic interaction between the photographer, the spectator, and the image" (Schwartz, 1989, p. 120). Seeing is closely linked to language and sensemaking. Entrepreneurs make sense out of what they see through thinking and talking. For example, Gartner, Carter, and Hills (2003) studied the language that so-called opportunity entrepreneurs used, attempting to "see" whether these are discovered or enacted. Indeed, many verbs the entrepreneurs used to talk about opportunities are connected to visualizing opportunities, which the authors took as an indicator for the discovery of opportunities: seeing, looking, noticing. But these verbs were mainly used in retrospect with "seeing" 
as a way to "make sense out of their experience (...) in starting a firm" (Gartner et al., 2003, p. 230), thus emphasizing a close link to enactment. Also, our ways of seeing and looking are gendered. In describing the appearance of women throughout history, drawing on how they are depicted in paintings, the art critic, author, painter and essayist John Berger (2008, p. 47) stated that "men act and women appear. Men look at women. Women watch themselves being looked at", pointing out that even today "the essential way of seeing women, the essential use to which their images are put, has not changed. Women are depicted in a quite different way from men-not because the feminine is different from the masculine-but because the 'ideal' spectator is always assumed to be male and the image of the woman is designed to flatter him" (Berger, 2008 , p. 64). Berger's words, written in the early 1970 s, resonate with us, reflecting the argumentation underlying our review on gender and entrepreneurship throughout this book. Berger adds to this by illustrating (pun acknowledged) how a focus on seeing can make us aware of nuances in our gendered perception of the world: women are seen differently and in many ways as more passive than men, which in turn often makes them see or perceive themselves as different in this way. "Watching themselves being looked as" is in turn likely the foundation for myriad other gendered distinctions in behavior, including some that shape entrepreneurship. And of course, the same processes shape men's perceptions of themselves as different from women. When the core topic is seeing, the difference between "looking at" and "being looked at" is rather extreme. All of this remains deeply embedded in contemporary culture.

So far, we have briefly outlined that seeing is neither a passive act nor something that happens within a vacuum. It happens in our everyday lives, as "everyday seeing” (Mitchell, 2002, p. 178). We see our surroundings, we see each other, we see what takes place and we see what others have seen, when looking at pictures and paintings, television, films, for example. In this regard, seeing is making sense out of what we look at, and that is, again, shaped by our preconceptions, our experiences, our familiarity with the imagery and what we are trying to accomplish. Images demand interpretation, and images are "worth a thousand questions" (ascribed to Allan Sekula, cited in Cadava, 2018, p. 48). Here, sight and language are closely linked because language is required for us to be able to contextualize these images: "it [the image] requires language to begin to give us a context through which we can start to situate the image in relation to the several traces that are sealed within it (. . .)." (Cadava, 2018, p. 52). Language does not fully determine how we see the world, but the words we use to describe the manifold acts of seeing certainly "testify to the meanings we attribute to various ways of acting in and upon our environments. They document how different our visual orientation is depending upon the significance of the people, things and events with which we are concerned" (Grady, 1996, p. 17). 
Seeing is not solely connected to still and moving images. We also can see "internally", when reading, for example, and visualizing the texts at the same time, or when dreaming. Similarly, seeing and actions are connected, because in many instances, "we cannot behave in ways we cannot imagine" (Gartner, 1993, p. 238). Berger (2013a, p. 86, originally published in Berger and Mohr (1982)) suggests that as soon as we look at our surroundings we read (different) meanings into the image, also interpreting what is visible and not visible. "What it [the photograph] shows invokes what is not shown. One can look at any photograph to appreciate the truth of this. The immediate relation between what is present and what is absent is particular to each photograph: it may be that of ice to sun, of grief to a tragedy, of a smile to a pleasure, of a body to love, of a winning race-horse to the race it has run" (Berger, 2013b, p. 20, italics in original text). We can look, but we may not see; rather, we "need to learn to read what is not visible within the image, but what has nevertheless left its traces in it" (Cadava, 2018, p. 48). Some of that reading happens more or less automatically and is universal in its meaning. For example, most of us are able to understand imagery such as the "not allowed" signs, without needing to know the underlying language (Peters, 2015). We look at these signs and immediately decode them, understanding what they mean. But we also read images by interpreting them in ways personal to us and to our experiences, as well as to our cultural background, the norms we are familiar with and the public discourses on what we should see. An illustration of this is to be found in the works of the Spanish fine art photographers Anna Cabrera and Ángel Albarrán. For example, in their series "This is you here", around identity and memories, they emphasize that each time we look at a photograph "related to our experiences, our intangible and unreliable memories surrender to the printed image" (www.albarrancabrera.com/this-is-youhere-statement), thus adding to what we see and interpret into the image. Thus, visualizing also is about interpreting what one sees, in the sense of adding what is not there to see, but which we believe should or could be there. We will come back to this in Part III of the book.

\section{How Entrepreneurs Visualize}

Along similar lines of visualizing as "seeing internally", social science scholars have looked at the role of imagination for individual and collective agency from various perspectives (for an overview of this concept in the entrepreneurship field see: Thompson, 2018a, 2018b). For example, Anderson $(2006$, p . 6) proposed nations as "imagined political communities", imagined in the sense that even in small nations the population will never know all of their fellows but still feel part of that national community. From the perspective of human geography, Debarbieux (2019) discusses the spatial dimensions of social imaginaries, which he suggests 
as constitutive element of modern societies: places, ways of direct interactions between individuals from the same "imagined community" and artefacts such as maps constitute the social imaginaries. As economic sociologist, Beckert (2016, p. 17) brings fictional expectations to the fore, outlining a different narrative of modern capitalism as (also) resulting from beliefs and re-conceptualizing "the notion of the 'iron cage' as colonizing creative and non-economically motivated expressions of agency". He draws on the example of fictional texts to explore how expectations of economic actors are fictional in the sense that they help imagining a future the actors cannot know of in the present. This is typical also for the ways in which entrepreneurs visualize: they imagine the future, when starting or developing their ventures, relying on their expectations and their stories about what will work and which outcomes they may achieve through their entrepreneurial actions. "Entrepreneurs talk and act 'as if' (...). Emerging organizations are elaborate fictions of proposed possible future states of existence" (Gartner, Bird, \& Starr, 1992, p. 17). Similarly, entrepreneurs relying on bricolage visualize through imagination, as Gartner and Baker (2010, p. 11) show, analyzing stories from a well-known entrepreneur in the U.S.: his reliance on "resources at hand" shaped both what he imagined and desired for the future and his assessment of its feasibility.

Extending entrepreneurship studies that rely on metaphors as reflecting non-verbal communication, researcher have started to look into visual elements of entrepreneurship (e.g., Barnes \& Newton, 2018; Berglund \& Wigren-Kristoferson, 2012; Clarke, 2011; Smith, 2015a, 2015b), sometimes with a focus on multimodal applications (e.g., Höllerer, Jancsary, \& Grafström, 2018) and on the interplay of imagery, verbal and non-verbal behavior, actions and gestures (e.g., Clarke, Cornelissen, \& Viney, 2015; Clarke, Cornelissen, \& Healey, 2019; Cornelissen, Clarke, \& Cienki, 2012). Such research holds promise of opening important new facets in our understanding of how entrepreneurs visually construct their contexts. Clarke and Holt (2019), for example, let entrepreneurs draw their experiences throughout venture creation instead of asking for verbal narratives, finding that drawings allow to access "alternative non-linear understanding of entrepreneurial experience". Others draw our attention to the close links between words and images as, for example, Boje and Smith (2010) who study how famous entrepreneurs visualize and re-story their entrepreneurial identities.

Some studies examine the ways entrepreneurs apply and use visual elements to deal with their business context and the results they achieve with those. For example, Clarke (2011) looked into visual symbols that entrepreneurs employ to gain support for their ventures. She identified four symbolic categories of visual symbols: setting (office and external surroundings), props (business related symbols such as prototypes or patents, high-status vehicles), dress and expressiveness (body and facial 
movements to convey emotions). Their use and effectiveness varied, depending on entrepreneurial experience: compared to the serial and experienced entrepreneurs, the novice entrepreneur used fewer symbols and was less confident in employing them, e.g., failing to use business dress appropriately and also not having in place the appropriate props required for effective interactions. The author shows ways in which entrepreneurs strategically used their "visual surroundings during performances with stakeholders" (Clarke 2011, p. 1384): they visually framed themselves and their businesses in ways that resonated with stakeholders' experiences. She concludes that "stories alone are insufficient to gain legitimacy and entrepreneurs must also direct attention to the impressions that visual surroundings, personal appearance, and expressiveness present about their company" (Clarke 2011, p. 1387).

Also of interest to how entrepreneurs do context in a visual way are studies that look into formal self-representations of business owners. Davison (2010) analyzes visual portraits of the business élite, showing how [in]visible [in]tangibles like reputation and standing are symbolically reflected in those portraits: physical codes visible through faces and stature; dress codes; interpersonal codes humanizing and individualizing business leaders; and spatial codes reflected in physical settings, and the visual set-up for the portrait. Other studies examine the impact of pictures on entrepreneurs. For example, Hentschel, Horvath, Peus, and Sczesny (2017) explore advertisements for entrepreneurship programs and the impact on applications by women, given potentially gendered images and linguistic forms. Women were less interested and perceived themselves as less suitable in those cases where the programs were advertised using typically masculine images and/or a solely masculine form for an entrepreneur. Their findings illustrate in which ways images can influence and contribute to gendering institutional contexts, but from a wider perspective also point to the agency individuals (entrepreneurs) might have in deciding on which images to pay attention to. Entrepreneurs also visualize through selecting which visual elements they want to be connected to their business. Anderson and Saxton (2016) studied this for imagery included in the loan requests of women micro-entrepreneurs represented on Kiva, a crowdfunding platform. Their results demonstrate that loan requests accompanied by baby images were associated with quicker funding, but those connected with images showing a man/husband or material status symbols experienced delays in funding. These and similar studies are encouraging in that they turn attention to an element of context construction that has been neglected so far in the entrepreneurship field. Future research will be able to use this work as the basis for moving beyond advice about how to structure campaigns and to dress toward insights about potential mechanisms and levers of change.

Robert Smith has pushed forward the use of visual analysis, frequently combined with other semiotic techniques and narrative analyses as 
previously discussed, to dig deeper into our taken-for-granted assumptions and stereotypes of entrepreneurship, thus going beyond the simpler approaches of studies outlined earlier and paving the way for a critical understanding of how entrepreneurs and other actors visually do contexts. For example, Smith (2014) identified a few archetypical, gendered stereotypes: the Business Woman, the Matriarch, the Diva, and the PinkGhetto Girl. While these are stereotypical representations of women (entrepreneurs), the author also concludes that women may have more options available in constructing their business identity and are not forced to adhere to the male norm. For the cover imagery used for entrepreneurship textbooks, Smith (2015a) showed that visual images and visual metaphors in these pictures and paintings do not present much evidence of the entrepreneur as hero-thus demonstrating how a visual analysis can add to a broader and more realistic picture of entrepreneurship.

We find the visual turn in our discipline promising, because this would allow us to take a closer look at hitherto neglected aspects of contextualizing entrepreneurship and the ways entrepreneurs enact their contexts. We also suggest that the management disciplines, in their visual turns, could benefit even further from closer attention paid to disciplines that have a long tradition of visualization such as ethnography or visual sociology and also integrating the insights from genuinely visual disciplines such as fine arts photography. Visualizing (and we can also visualize through the use of language with metaphors) contexts can turn our world upside down. It can make us change perspectives and question the ways we have so far seen and interpreted entrepreneurship. Seeing and visualizing both make the invisible visible and sometimes push to the background what otherwise dominates our vision of entrepreneurship.

\section{Seeing Matters}

So far in this chapter, we have explored three inextricably intertwined strands of entrepreneurs doing context. We were able to review many studies that we classified as being about enactment. There also is a growing number of studies well-described as doing context by talking. Our discussion of doing context by seeing drew more heavily on theoretical work from outside of entrepreneurship, especially from theoretical work on photography. We believe that each of these strands, separately and in combination continues to offer great promise for our understanding of how entrepreneurs do context as they play with the apparent affordances and constraints of the environments in which they find themselves.

While we know more about some kinds of enactment processes in entrepreneurship than we know about "talking" and "seeing", across all of these areas, research has only begun to touch the surface of what it will be interesting and useful to discover. It is also important to point out that there exist large bodies of scholarship across multiple disciplines that 
entrepreneurship scholars can call upon, as we continue these exploratory journeys toward understanding more about the processes and boundaries of entrepreneurial agency. In the next chapter, we turn from our focus on entrepreneurs doing context to an examination of researchers doing context, as we propose research programs shaped by what we describe as a Critical Process Approach.

\section{References}

Achtenhagen, L., Naldi, L., \& Melin, L. (2010). Business growth: Do practitioners and scholars really talk about the same thing? Entrepreneurship Theory and Practice, 34(2), 289-316.

Achtenhagen, L., \& Welter, F. (2011). Surfing on the ironing board: The representation of women's entrepreneurship in German newspapers. Entrepreneurship \& Regional Development, 23(9-10), 763-786.

Akman, V. (2000). Rethinking context as a social construct. Journal of Pragmatics, 32(6), 743-759.

Akman, V., \& Bazzanella, C. (2003). The complexity of context: Guest editors' introduction. Journal of Pragmatics, 35(3), 321-329.

Al-Dajani, H., Akbar, H., Carter, S., \& Shaw, E. (2019). Defying contextual embeddedness: Evidence from displaced women entrepreneurs in Jordan. Entrepreneurship \& Regional Development, 31(3-4), 198-212.

Aldrich, H., \& Ruef, M. (2006). Organizational evolution and entrepreneurship. London: Sage Publications.

Alvi, F. H., Prasad, A., \& Segarra, P. (2019). The political embeddedness of entrepreneurship in extreme contexts: The case of the West Bank. Journal of Business Ethics, 157(1), 279-292.

Anderson, B. (2006). Imagined communities. London: Verso.

Anderson, K. B., \& Saxton, G. D. (2016). Smiles, babies, and status symbols: The persuasive effects of image choices in small-entrepreneur crowdfunding requests. International Journal of Communication, 10, 1764-1785.

Auer, P. (1995). From context to contextualization. Links \& Letters, 3, 11-28.

Baker, T., Gedajlovic, E., \& Lubatkin, M. (2005). A framework for comparing entrepreneurship processes across nations. Journal of International Business Studies, 36(5), 492-504.

Baker, T., \& Nelson, R. E. (2005). Creating something from nothing: Resource construction through entrepreneurial bricolage. Administrative Science Quarterly, 50(3), 329-366.

Baker, T., \& Powell, E. E. (2016). Let them eat bricolage? Toward a contextualized notion of inequality of entrepreneurial opportunity. In F. Welter \& W. B. Gartner (Eds.), A research agenda for entrepreneurship and context (pp. 41-53). Cheltenham: Edward Elgar.

Baker, T., \& Welter, F. (2017). Come on out of the ghetto, please: Building the future of entrepreneurship research. International Journal of Entrepreneurial Behaviour \& Research, 23(2), 170-184.

Balachandra, L., Briggs, T., Eddleston, K., \& Brush, C. (2017). Don't pitch like a girl: How gender stereotypes influence investor decisions. Entrepreneurship Theory and Practice, 43(1), 116-137. 
Bar, M. (2004). Visual objects in context. Nature Reviews: Neuroscience, 5(8), 617-629. doi:10.1038/nrn1476

Barnes, V., \& Newton, L. (2018). Visualizing organizational identity: The history of a capitalist enterprise. Management \& Organizational History, 13(1), 24-53.

Bates, E. (1976). Language and context: The acquisition of pragmatics. New York, NY: Academic Press.

Beckert, J. (2016). Imagined futures: Fictional expectations and capitalist dynamics. London; Cambridge, MA: Harvard University Press.

Berger, J. (2008). Ways of seeing. London: Penguin.

Berger, J. (2013a). Appearances: The ambiguity of the photograph. In G. Dyer (Ed.), Understanding a photograph (pp. 61-98). London: Penguin.

Berger, J. (2013b). John Berger: Understanding a photograph. In G. Dyer (Ed.), Understanding a photograph (pp. 17-21). London: Penguin.

Berger, J., \& Mohr, J. (1982). Another way of telling. London: Writers \& Readers.

Berger, P. L., \& Luckmann, T. (1966). The social construction of reality: A treatise in the sociology of knowledge. New York, NY: Doubleday and Company.

Berglund, K. A. E., \& Wigren-Kristoferson, C. (2012). Using pictures and artefacts in a PAR process to disclose new wor(l)ds of entrepreneurship. Action Research, 10(3), 276-292.

Boas, F. (1945). Race and democratic society. New York, NY: Augustin.

Boje, D., \& Smith, R. (2010). Re-storying and visualizing the changing entrepreneurial identities of Bill Gates and Richard Branson. Culture and Organization, 16(4), 307-331.

Brännback, M., \& Carsrud, A. (2016). Understanding entrepreneurial cognitions through the lenses of context. In F. Welter \& W. B. Gartner (Eds.), A research agenda on entrepreneurship and context (pp. 16-27). Cheltenham: Edward Elgar.

Bruni, E., Bonesso, S., \& Gerli, F. (2019). Coping with different types of innovation: What do metaphors reveal about how entrepreneurs describe the innovation process? Creativity and Innovation Management. Online early. doi:10.1111/caim.12312

Bruno, M. (1997). Women and the culture of entrepreneurship. In M. Buckley (Ed.), Post-Soviet women: From the Baltic to Central Asia (pp. 56-74). Cambridge: Cambridge University Press.

Bullough, A., Renko, M., \& Myatt, T. (2014). Danger zone entrepreneurs: The importance of resilience and self: Efficacy for entrepreneurial intentions. Entrepreneurship Theory and Practice, 38(3), 473-499.

Byrne, J., Fattoum, S., \& Diaz Garcia, M. C. (2019). Role models and women entrepreneurs: Entrepreneurial superwoman has her say. Journal of Small Business Management, 57(1), 154-184.

Cadava, E. (2018). Learning to see. In Susan Meiselas: Mediations (pp. 41-68). Paris, Barcelona, Bologna: Damiani.

Cardon, M. S., Zietsma, C., Saparito, P., Matherne, B. P., \& Davis, C. (2005). A tale of passion: New insights into entrepreneurship from a parenthood metaphor. Journal of Business Venturing, 20(1), 23-45.

Chlosta, S., \& Welter, F. (2017). Context and entrepreneurial cognition. In M. Brännback \& A. L. Carsrud (Eds.), Revisiting the entrepreneurial mind (pp. 91-99). Cham: Springer. 
Chun, M. M., \& Jiang, Y. (1998). Contextual cueing: Implicit learning and memory of visual context guides spatial attention. Cognitive Psychology, 36(1), 28-71.

Clarke, J. S. (2011). Revitalizing entrepreneurship: How visual symbols are used in entrepreneurial performances. Journal of Management Studies, 48(6), 1365-1391.

Clarke, J. S., Cornelissen, J., \& Viney, R. (2015). Seeing entrepreneurs in action: Using video-based gesture analysis in entrepreneurship. Academy of Management Proceedings, 2015(1), 11921.

Clarke, J. S., \& Cornelissen, J. P. (2014). How language shapes thought: New vistas for entrepreneurship research. In J. R. Mitchell, R. K. Mitchell, \& B. Randolph-Seng (Eds.), Handbook of entrepreneurial cognition (pp. 388-397). Cheltenham: Edward Elgar.

Clarke, J. S., Cornelissen, J. P., \& Healey, M. P. (2019). Actions speak louder than words: How figurative language and gesturing in entrepreneurial pitches influences investment judgments. Academy of Management Journal, 62(2), 335-360.

Clarke, J., \& Holt, R. (2010). The mature entrepreneur: A narrative approach to entrepreneurial goals. Journal of Management Inquiry, 19(1), 69-83.

Clarke, J. S., \& Holt, R. (2019). Images of entrepreneurship: Using drawing to explore entrepreneurial experience. Journal of Business Venturing Insights, 11. doi:10.1016/j.jbvi.2019.e00129

Corbett, A. C., \& Katz, J. A. (Eds.). (2013). Entrepreneurial resourcefulness: Competing with constraints. Bingley: Emerald Group Publishing Limited.

Cornelissen, J. (2006). Metaphor in organization theory: Progress and the past. Academy of Management Review, 31(2), 485-488.

Cornelissen, J. P. (2005). Beyond compare: Metaphor in organization theory. Academy of Management Review, 30(4), 751-764.

Cornelissen, J. P., Clarke, J. S., \& Cienki, A. (2012). Sensegiving in entrepreneurial contexts: The use of metaphors in speech and gesture to gain and sustain support for novel business ventures. International Small Business Journal, 30(3), 213-241.

Daly, P., \& Davy, D. (2016). Structural, linguistic and rhetorical features of the entrepreneurial pitch: Lessons from Dragons' Den. Journal of Management Development, 35(1), 120-132.

Davison, J. (2010). [In] visible [in] tangibles: Visual portraits of the business élite. Accounting, Organizations and Society, 35(2), 165-183.

De Castro, J. O., Khavul, S., \& Bruton, G. D. (2014). Shades of grey: How do informal firms navigate between macro and meso institutional environments? Strategic Entrepreneurship Journal, 8(1), 75-94.

De Koning, A., \& Drakopoulou-Dodd, S. (2002). "Raising babies, fighting battles, winning races: Entrepreneurial metaphors in the media of 6 English speaking nations." Paper presented at the Babson-Kauffman Research Conference, Boulder, CO.

Debarbieux, B. (2019). Social imaginaries of space. Cheltenham: Edward Elgar.

DiMaggio, P. J., \& Powell, W. W. (1983). The iron cage revisited: Institutional isomorphism and collective rationality in organizational fields. American Sociological Review, 48(2), 147-160.

Dourish, P. (2004). What we talk about when we talk about context. Personal and Ubiquitous Computing, 8(1), 19-30. 
Drakopoulou Dodd, S., Pret, T., \& Shaw, E. (2016). Advancing understanding of entrepreneurial embeddedness: Forms of capital, social contexts and time. In F. Welter \& W. B. Gartner (Eds.), A research agenda on entrepreneurship and context (pp. 120-133). Cheltenham: Edward Elgar.

Dror, E., \& Fabrizio, F. (2010). The role of analogy in the institutionalization of sustainability reporting. Organization Science, 21(5), 1092-1107.

Edmonds, B., \& Akman, V. (2002). Editorial: Context in context. Foundations of Science, 7(3), 233-238.

Elfving, J., Brännback, M., \& Carsrud, A. (2009). Toward a contextual model of entrepreneurial intentions. In A. L. Carsrud \& M. Brännback (Eds.), Understanding the entrepreneurial mind: Opening the black box (pp. 23-33). New York, NY: Springer.

Elfving, J., Brännback, M., \& Carsrud, A. (2017). Revisiting a contextual model of entrepreneurial intentions. In M. Brännback \& A. L. Carsrud (Eds.), Revisiting the entrepreneurial mind: Inside the black box: An expanded edition (pp. 83-90). Cham: Springer.

Felski, R. (2011). Context stinks. New Literary History, 42(4), 573-591.

Fisher, G., Kuratko, D. F., Bloodgood, J. M., \& Hornsby, J. S. (2017). Legitimate to whom? The challenge of audience diversity and new venture legitimacy. Journal of Business Venturing, 32(1), 52-71.

Fletcher, D. E. (2006). Entrepreneurial processes and the social construction of opportunity. Entrepreneurship Theory and Practice, 18(4), 421-440.

Foss, L. (2004). Going against the grain . . . : Construction of entrepreneurial identity through narratives. In D. Hjorth \& C. Steyaert (Eds.), Narrative and discursive approaches in entrepreneurship: A second movements in entrepreneurship book (pp. 80-104). Cheltenham: Edward Elgar.

Gaddefors, J. (2007). Metaphor use in the entrepreneurial process. International Journal of Entrepreneurial Behavior \& Research, 13(3), 173-193.

Gaddefors, J., \& Anderson, A. R. (2017). Entrepreneursheep and context: When entrepreneurship is greater than entrepreneurs. International Journal of Entrepreneurial Behavior \& Research, 23(2), 267-278.

Gaddefors, J., \& Anderson, A. R. (2019). Romancing the rural: Reconceptualizing rural entrepreneurship as engagement with context(s). The International Journal of Entrepreneurship and Innovation, 20(3), 159-169.

Gaddefors, J., \& Cronsell, N. (2009). Returnees and local stakeholders coproducing the entrepreneurial region. European Planning Studies, 17(8), 1191-1203.

Garfinkel, H. (1967). Studies in ethnomethodology. Englewood Cliffs, NJ: Prentice-Hall.

Gartner, W. B. (1988). Who is an entrepreneur? Is the wrong question. American Journal of Small Businesses, 12(4), 11-32.

Gartner, W. B. (1990). What are we talking about when we talk about entrepreneurship? Journal of Business Venturing, 5(1), 15-28.

Gartner, W. B. (1993). Words lead to deeds: Towards an organizational emergence vocabulary. Journal of Business Venturing, 8(3), 231-239.

Gartner, W. B., \& Baker, T. (2010). A plausible history and exploration of Stevenson's definition of entrepreneurship. Frontiers of Entrepreneurship Research, 30(4), 2. 
Gartner, W. B., Bird, B. J., \& Starr, J. A. (1992). Acting as if: Differentiating entrepreneurial from organizational behavior. Entrepreneurship Theory and Practice, 16(3), 13-32.

Gartner, W. B., \& Carter, N. (2003). Entrepreneurial behaviour and firm organizing processes. In Z. J. Acs \& D. B. Audretsch (Eds.), Handbook of entrepreneurship research (pp.195-221). New York, NY: Springer.

Gartner, W. B., Carter, N. M., \& Hills, G. E. (2003). The language of opportunity. In C. Steyaert \& D. Hjorth (Eds.), New movements in entrepreneurship (pp.103-124). Cheltenham: Edward Elgar.

Gill, R., \& Larson, G. S. (2014). Making the ideal (local) entrepreneur: Place and the regional development of high-tech entrepreneurial identity. Human Relations, 67(5), 519-542.

Gorbatai, A. D., \& Nelson, L. (2015). Gender and the language of crowdfunding. Academy of Management Proceedings, 2015(1), 15785.

Grady, J. (1996). The scope of visual sociology. Visual Studies, 11(2), 10-24.

Gregory, S. (2012). Detroit is a blank slate: Metaphors in the journalistic discourse of art and entrepreneurship in the city of Detroit. EPIC, 2012(1), 217-233.

Grube, L. E., \& Storr, V. H. (2018). Embedded entrepreneurs and post-disaster community recovery. Entrepreneurship \& Regional Development, 30(7-8), 800-821.

Gumperz, J. J. (1992). Contextualization and understanding. In A. Duranti \& C. Goodwin (Eds.), Rethinking context: Language as an interactive phenomenon (pp.229-252). Cambridge: Cambridge University Press.

Han, C. R., Nelen, H., \& Kang, Y. (2015). A case study on shuttle trade between Korea and China. Journal of Borderlands Studies, 30(3), 437-451.

Hannan, M. T., \& Freeman, J. (1977). The population ecology of organizations. American Journal of Sociology, 82(5), 929-964.

Hechavarría, D. M., Terjesen, S. A., Stenholm, P., Brännback, M., \& Lång, S. (2018). More than words: Do gendered linguistic structures widen the gender gap in entrepreneurial activity? Entrepreneurship Theory and Practice. Online early. doi:10.1111/etap.12278

Hentschel, T., Horvath, L., Peus, C., \& Sczesny, S. (2017). Raising women's interest in entrepreneurship: Effects of images and language in advertisements. Academy of Management Proceedings, 2017(1), 16894.

Höllerer, M. A., Jancsary, D., \& Grafström, M. (2018). A picture is worth a thousand words: Multimodal sensemaking of the global financial crisis. Organization Studies, 39(5-6), 617-644.

Hymes, D. (1974). Ways of speaking. In R., Bauman, \& J. Sherzer (Eds.), Explorations in the ethnography of speaking (pp. 433-451). London: Cambridge University Press.

Hyrsky, K. (1998). Entrepreneurship: Metaphors and related concepts. Journal of Enterprising Culture, 6(4), 391-412.

Jack, S. L., \& Anderson, A. R. (2002). The effects of embeddedness on the entrepreneurial process. Journal of Business Venturing, 17(5), 467-487.

Johannisson, B. (1990). Community entrepreneurship-cases and conceptualization. Entrepreneurship \& Regional Development, 2(1), 71-88.

Johannisson, B. (2011). Towards a practice theory of entrepreneuring. Small Business Economics, 36(2), 135-150.

Johannisson, B., \& Nilsson, A. (1989). Community entrepreneurs: Networking for local development. Entrepreneurship \& Regional Development, 1(1), 3-19. 
Johnstone, H., \& Lionais, D. (2004). Depleted communities and community business entrepreneurship: Revaluing space through place. Entrepreneurship \& Regional Development, 16(3), 217-233.

Kanze, D., Huang, L., Conley, M. A., \& Higgins, E. T. (2018). We ask men to win and women not to lose: Closing the gender gap in startup funding. Academy of Management Journal, 61(2), 586-614.

Ketokivi, M., Mantere, S., \& Cornelissen, J. (2017). Reasoning by analogy and the progress of theory. Academy of Management Review, 42(4), 637-658.

Kjellander, B., Nordqvist, M., \& Welter, F. (2012). Identity dynamics in the family business context: A novel ('s) perspective. In A. L. Carsrud \& M. Brännback (Eds.), Understanding family businesses (pp. 39-53). New York, NY: Springer.

Koning, A. (2003). Opportunity development: A socio-cognitive perspective. In J. A. Katz \& D. A. Shepherd (Eds.), Cognitive approaches to entrepreneurship research (1st ed. pp. 265-314). Amsterdam: JAI.

Korsgaard, S., Ferguson, R., \& Gaddefors, J. (2015). The best of both worlds: How rural entrepreneurs use placial embeddedness and strategic networks to create opportunities. Entrepreneurship \& Regional Development, 27(9-10), 574-598.

Kwong, C. C., Cheung, C. W., Manzoor, H., \& Rashid, M. U. (2019). Entrepreneurship through Bricolage: A study of displaced entrepreneurs at times of war and conflict. Entrepreneurship \& Regional Development, 31(5-6), 435-455.

Labov, W. (1970). The study of language in its social context. Berlin: Springer.

Langevang, T., \& Namatovu, R. (2019). Social bricolage in the aftermath of war. Entrepreneurship \& Regional Development. Online early. doi:10.1080/08985 626.2019.1595743

Langmann, S., \& Pick, D. (2018). Photography as a social research method. Singapore: Springer.

Lundmark, E., Krzeminska, A., \& Shepherd, D. A. (2019). Images of entrepreneurship: Exploring root metaphors and expanding upon them. Entrepreneurship Theory and Practice, 43(1), 138-170.

Lundmark, E., \& Westelius, A. (2014). Entrepreneurship as elixir and mutagen. Entrepreneurship Theory and Practice, 38(3), 575-600.

Maclean, M., Harvey, C., Gordon, J., \& Shaw, E. (2015). Identity, storytelling and the philanthropic journey. Human Relations, 68(10), 1623-1652.

Mair, J., \& Marti, I. (2009). Entrepreneurship in and around institutional voids: A case study from Bangladesh. Journal of Business Venturing, 24(5), 419-435.

Malmström, M., Johansson, J., \& Wincent, J. (2017). Gender stereotypes and venture support decisions: How governmental venture capitalists socially construct entrepreneurs' potential. Entrepreneurship Theory and Practice, 41(5), 833-860.

Manolova, T. S., \& Yan, A. (2002). Institutional constraints and entrepreneurial responses in a transforming economy: The case of Bulgaria. International Small Business Journal, 20(2), 163-184.

Markowska, M., \& Welter, F. (2018). Narrating entrepreneurial identities. How achievement motivation influences restaurateurs' identity construction? In U. Hytti, R. Blackburn, \& E. Laveren (Eds.), Entrepreneurship, innovation and education (pp. 165-187). Cheltenham: Edward Elgar.

Mason, C., Reuschke, D., Syrett, S., \& van Ham, M. (Eds.). (2015). Entrepreneurship in cities: Neighbourhoods, households and homes. Cheltenham: Edward Elgar. 
McCarthy, D. J., \& Puffer, S. M. (2016). Institutional voids in an emerging economy: From problem to opportunity. Journal of Leadership \& Organizational Studies, 23(2), 208-219.

McKeever, E., Jack, S., \& Anderson, A. (2015). Embedded entrepreneurship in the creative re-construction of place. Journal of Business Venturing, 30(1), 50-65.

Mehan, H., \& Wood, H. (1975). The reality of ethnomethodology. New York, NY: John Wiley \& Sons Inc.

Merleau-Ponty, M. (1964). Sense and non-sense. Chicago, IL: Northwestern University Press.

Misra, S., \& Kumar, E. S. (2000). Resourcefulness: A Proximal conceptualisation of entrepreneurial behaviour. Journal of Entrepreneurship, 9, 135-154.

Mitchell, W. J. T. (2002). Showing seeing: A critique of visual culture. Journal of Visual Culture, 1(2), 165-181.

Moss, T. W., Renko, M., Block, E., \& Meyskens, M. (2018). Funding the story of hybrid ventures: Crowdfunder lending preferences and linguistic hybridity. Journal of Business Venturing, 33(5), 643-659.

Müller, S., \& Korsgaard, S. (2018). Resources and bridging: The role of spatial context in rural entrepreneurship. Entrepreneurship \& Regional Development, 30(1-2), 224-255.

Muñoz, P., Kimmitt, J., Kibler, E., \& Farny, S. (2019). Living on the slopes: Entrepreneurial preparedness in a context under continuous threat. Entrepreneurship \& Regional Development, 31(5-6), 413-434.

Nelson, R., \& Lima, E. (2019). Effectuations, social bricolage and causation in the response to a natural disaster. Small Business Economics. Online early. doi:10.1007/s11187-019-00150-z

Ngoasong, M. Z., \& Kimbu, A. N. (2019). Why hurry? The slow process of high growth in women-owned businesses in a resource-scarce context. Journal of Small Business Management, 57(1), 40-58.

Nicholson, L., \& Anderson, A. R. (2005). News and nuances of the entrepreneurial myth and metaphor: Linguistic games in entrepreneurial sense: Making and sense: Giving. Entrepreneurship Theory and Practice, 29(2), 153-172.

O'Connor, E. (2004). Storytelling to be real: Narrative, legitimacy building and venturing. In D. Hjorth \& C. Steyaert (Eds.), Narrative and discursive approaches in entrepreneurship: A second movements in entrepreneurship book (pp. 105-124). Cheltenham: Edward Elgar.

Ogbor, J. O. (2000). Mythicizing and reification in entrepreneurial discourse: Ideology-critique of entrepreneurial studies. Journal of Management Studies, 37(5), 605-636.

Parhankangas, A., \& Renko, M. (2017). Linguistic style and crowdfunding success among social and commercial entrepreneurs. Journal of Business Venturing, 32(2), 215-236.

Parkinson, C., \& Howorth, C. (2008). The language of social entrepreneurs. Entrepreneurship \& Regional Development, 20(3), 285-309.

Parkinson, C., Howorth, C., \& Southern, A. (2017). The crafting of an (un)enterprising community: Context and the social practice of talk. International Small Business Journal-Researching Entrepreneurship, 35(4), 385-404.

Peredo, A. M., \& Chrisman, J. J. (2006). Toward a theory of community-based enterprise. Academy of Management Review, 31(2), 309-328. 
Peredo, A. M., \& Chrisman, J. J. (2017). Conceptual foundations: Communitybased enterprise and community development. In M. Van Ham, D. Reuschke, R. Kleinhans, C. Mason, \& S. Syrett (Eds.), Entrepreneurial Neighbourhoods (pp. 151-178). Cheltenham: Edward Elgar.

Perkins, D. N., \& Salomon, G. (1989). Are cognitive skills context-bound? Educational Researcher, 18(1), 16-25.

Peters, J. D. (2015). The marvelous clouds: Towards a philosophy of elemental media. London; Chicago, IL: University of Chicago Press.

Powell, E. E., \& Baker, T. (2014). It's what you make of it: Founder identity and enacting strategic responses to adversity. Academy of Management Journal, 57(5), 1406-1433.

Powell, E. E., \& Baker, T. (2017). In the beginning: Identity processes and organizing in multi-founder nascent ventures. Academy of Management Journal, 60(6), 2381-2414.

Powell, E. E., Hamann, R., Bitzer, V., \& Baker, T. (2018). Bringing the elephant into the room? Enacting conflict in collective prosocial organizing. Journal of Business Venturing, 33(5), 623-642.

Puffer, S. M., McCarthy, D. J., \& Boisot, M. (2010). Entrepreneurship in Russia and China: The impact of formal institutional voids. Entrepreneurship Theory and Practice, 34(3), 441-467.

Ruebottom, T. (2013). The microstructures of rhetorical strategy in social entrepreneurship: Building legitimacy through heroes and villains. Journal of Business Venturing, 28(1), 98-116.

Schwartz, D. (1989). Visual ethnography: Using photography in qualitative research. Qualitative Sociology, 12(2), 119-154.

Shepherd, D. A., \& Williams, T. A. (2014). Local venturing as compassion organizing in the aftermath of a natural disaster: The role of localness and community in reducing suffering. Journal of Management Studies, 51(6), 952-994.

Smallbone, D., \& Welter, F. (2001). The distinctiveness of entrepreneurship in transition economies. Small Business Economics, 16(4), 249-262.

Smith, R. (2009). The Diva storyline: An alternative social construction of female entrepreneurship. International Journal of Gender and Entrepreneurship, 1(2), 148-163.

Smith, R. (2010). Masculinity, doxa and the institutionalisation of entrepreneurial identity in the novel cityboy. International Journal of Gender and Entrepreneurship, 2(1), 27-48.

Smith, R. (2013). Documenting Essex-Boy as a local gendered regime. International Journal of Gender and Entrepreneurship, 5(2), 174-197.

Smith, R. (2014). Images, forms and presence outside and beyond the pink ghetto. Gender in Management, 29(8), 466-486.

Smith, R. (2015a). Con'text'ualizing images of enterprise: An examination of 'visual metaphors' used to represent entrepreneurship in textbooks. In $\mathrm{H}$. Neergaard \& C. Leitch (Eds.), Qualitative research techniques and analysis in entrepreneurship (pp. 139-169). Cheltenham: Edward Elgar.

Smith, R. (2015b). Seeing the light: Using visual ethnography in family business settings. Family Business Review, 28(1), 76-82.

Steyaert, C., Hjorth, D., \& Gartner, W. B. (2011). Six memos for a curious and imaginative future scholarship in entrepreneurship studies. Entrepreneurship \& Regional Development, 23(1-2), 1-7. 
Sutter, C. J., Webb, J. W., Kistruck, G. M., \& Bailey, A. V. G. (2013). Entrepreneurs' responses to semi-formal illegitimate institutional arrangements. Journal of Business Venturing, 28(6), 743-758.

Thompson, N. A. (2018a). Critiquing and renewing the entrepreneurial imagination. In A. Fayolle, S. Ramoglou, M. Karatas-Ozkan, \& K. Nicolopoulou (Eds.), Philosophical reflexivity and entrepreneurship research (pp. 126-138). Abingdon: Routledge.

Thompson, N. A. (2018b). Imagination and creativity in organizations. Organization Studies, 39(2-3), 229-250.

Tlaiss, H. A. (2019). Contextualizing the career success of Arab women entrepreneurs. Entrepreneurship \& Regional Development, 31(3-4), 226-241.

Tracey, P., \& Phillips, N. (2011). Entrepreneurship in emerging markets. Management International Review, 51(1), 23-39.

Tuan, Y. F. (1991). Language and the making of place: A narrative-descriptive approach. Annals of the Association of American Geographers, 81(4), 684-696.

Uzunca, B., Rigtering, J. P. C., \& Ozcan, P. (2018). Sharing and shaping: A crosscountry comparison of how sharing economy firms shape their institutional environment to gain legitimacy. Academy of Management Discoveries, 4(3), 248-272.

Van Ham, M., Reuschke, D., Kleinhans, R., Mason, C., \& Syrett, S. (Eds.). (2017). Entrepreneurial neighbourhoods: Towards an understanding of the economies of neighbourhoods and communities. Cheltenham: Edward Elgar.

van Werven, R., Bouwmeester, O., \& Cornelissen, J. P. (2015). The power of arguments: How entrepreneurs convince stakeholders of the legitimate distinctiveness of their ventures. Journal of Business Venturing, 30(4), 616-631.

van Werven, R., Bouwmeester, O., \& Cornelissen, J. P. (2019). Pitching a business idea to investors: How new venture founders use micro-level rhetoric to achieve narrative plausibility and resonance. International Small Business Journal, 37(3), 193-214.

Villares-Varela, M., \& Essers, C. (2019). Women in the migrant economy. A positional approach to contextualize gendered transnational trajectories. Entrepreneurship \& Regional Development, 31(3-4), 213-225.

Warren, L. (2005). Images of entrepreneurship: Still searching for the hero? The International Journal of Entrepreneurship and Innovation, 6(4), 221-229.

Webb, J. W., Ireland, R. D., \& Ketchen, D. J. (2014). Toward a greater understanding of entrepreneurship and strategy in the informal economy. Strategic Entrepreneurship Journal, 8(1), 1-15.

Weick, K. E. (1979). The social psychology of organizing (2nd ed.). Reading, MA: Addison-Wesley.

Weick, K. E. (1989). Theory construction as disciplined imagination. Academy of Management Review, 14(4), 516-531.

Weick, K. E., Sutcliffe, K. M., \& Obstfeld, D. (2005). Organizing and the process of sensemaking. Organization Science, 16(4), 409-421.

Welter, F. (2011). Contextualizing entrepreneurship: Conceptual challenges and ways forward. Entrepreneurship Theory and Practice, 35(1), 165-184.

Welter, F. (2019). The power of words and images: Towards talking about and seeing entrepreneurship and innovation differently. In D. Audretsch, E. Lehmann, \& A. N. Link (Eds.), A research agenda for entrepreneurship and innovation (pp. 179-196). Cheltenham: Edward Elgar. 
Welter, F., \& Smallbone, D. (2009). The emergence of entrepreneurial potential in transition environments: A challenge for entrepreneurship theory or a developmental perspective? In D. Smallbone, H. Landström, \& D. Jones-Evans (Eds.), Entrepreneurship and growth in local, regional and national economies: Frontiers in European entrepreneurship research (pp. 339-353). Cheltenham: Edward Elgar.

Welter, F., \& Smallbone, D. (2010). The embeddedness of women's entrepreneurship in a transition context. In C. G. Brush, A. De Bruin, E. Gatewood, \& C. Henry (Eds.), Women entrepreneurs and the global environment for growth: A research perspective (pp. 96-117). Cheltenham: Edward Elgar.

Welter, F., \& Smallbone, D. (2011). Institutional perspectives on entrepreneurial behavior in challenging environments. Journal of Small Business Management, 49(1), 107-125.

Welter, F., \& Xheneti, M. (2013). Reenacting contextual boundaries: Entrepreneurial resourcefulness in challenging environments. In A. C. Corbett \& J. Katz (Eds.), Entrepreneurial resourcefulness: Competing with constraints (pp. 149-183). Bingley: Emerald Group Publishing Limited.

Welter, F., \& Xheneti, M. (2015). Value for whom? Exploring the value of informal entrepreneurial activities in post-socialist contexts. In G. McElwee \& R. Smith (Eds.), Exploring criminal and illegal enterprise: New perspectives on research, policy and practice (pp. 253-275). Bingley: Emerald Group Publishing Limited.

Welter, F., Xheneti, M., \& Smallbone, D. (2018). Entrepreneurial resourcefulness in unstable institutional contexts: The example of European Union borderlands. Strategic Entrepreneurship Journal, 12(1), 23-53.

West, C., \& Zimmerman, D. H. (1987). Doing gender. Gender \& Society, 1(2), $125-151$.

Wheadon, M., \& Duval-Couetil, N. (2018). The gendering of entrepreneurship on reality television. Journal of Small Business Management. Online early. doi:10.1111/jsbm.12443

Wheadon, M., \& Duval-Couetil, N. (2019). Token entrepreneurs: A review of gender, capital, and context in technology entrepreneurship. Entrepreneurship \& Regional Development, 31(3-4), 308-336.

Whorf, B. L. (1956). Language, thought, and reality. In J. B. Carroll (Ed.), Selected writings of Benjamin Lee Whorf. Cambridge, MA: Massachusetts Institute of Technology Press.

Wieland, A. M., Kemmelmeier, M., Gupta, V. K., \& McKelvey, W. (2019). Gendered cognitions: A socio-cognitive model of how gender affects entrepreneurial preferences. Entrepreneurship \& Regional Development, 31(3-4), 178-197.

Williams, C. C., \& Nadin, S. J. (2013). Beyond the entrepreneur as a heroic figurehead of capitalism: Re-representing the lived practices of entrepreneurs. Entrepreneurship \& Regional Development, 25(7-8), 552-568.

Williams, C. C., \& Shahid, M. S. (2014). Informal entrepreneurship and institutional theory: Explaining the varying degrees of (in)formalization of entrepreneurs in Pakistan. Entrepreneurship \& Regional Development, 28(1-2), 1-25.

Williams, T. A., \& Shepherd, D. A. (2016a). Building resilience or providing sustenance: Different paths of emergent ventures in the aftermath of the Haiti earthquake. Academy of Management Journal, 59(6), 2069-2102.

Williams, T. A., \& Shepherd, D. A. (2016b). Victim entrepreneurs doing well by doing good: Venture creation and well-being in the aftermath of a resource shock. Journal of Business Venturing, 31(4), 365-387. 


\section{Theorizing Contexts}

Xheneti, M., Karki, S. T., \& Madden, A. (2019). Negotiating business and family demands within a patriarchal society: The case of women entrepreneurs in the Nepalese context. Entrepreneurship \& Regional Development, 31(3-4), 259-278.

Yousafzai, S., Fayolle, A., Saeed, S., Henry, C., \& Lindgreen, A. (2019). The contextual embeddedness of women's entrepreneurship: towards a more informed research agenda. Entrepreneurship \& Regional Development, 31 (3-4), 167-177.

\section{Website}

Retrieved 15 August 2019, from www.albarrancabrera.com/this-is-you-herestatement 


\section{Problematizing, Making Choices and Asking Who Our Research Serves}

Earlier, we introduced some common themes and patterns of contextualization and showed how entrepreneurship research has-or has notdealt with contexts over time and what "doing context" implies. We then focused on how entrepreneurs themselves do context, discussing contextualization in terms of enactment, use of language and images. In this chapter we now will turn to theorizing contexts as a Critical Process Approach, attempting to go beyond what the sociologist Rachel Rosenfeld, reflecting on the state of much gender research in the 1980s and 1990s, criticized during a seminar attended by one of the authors as "add gender and stir". Our focus here is on researchers doing context: on the choices researchers make, and to some extent on how these are embedded in the social structures in which we operate and the terms by which careers, resources, status and rewards are made available. But when we begin to interrogate these structures by asking "who does our research serve"? our basic argument is in favor of making choices that are more cognizant of and critical toward the varied structures of inequality and domination that are frequently in play and shaping how entrepreneursand researchers-do contexts.

In this chapter, we first use the idea of trade-offs between the simple, the accurate and the general to make the case that we "can't do it all" and that there are limits to the value of contextualizing our research. We then describe "theorizing contexts" as a matter of problematizing, and as a matter of researchers' choice, but as a matter of choice that is profoundly shaped by power and privilege. We use this to examine who our research serves and use the answers to develop a Critical Process Approach (CPA) to theorizing contexts. The CPA, which is something of a metatheoretical orientation, is critical because it takes practical and moral issue with the contours of power and privilege that channel who our research serves; it is a process because it recognizes that the attempt to open up to scrutiny and dismantle any reified assumption that serve powerful interests needs to be sustained and joined by multiple researchers; it is an approach, rather than a technique, because it does not by itself provide satisfying answers of the "do this and things will get better" variety. 
Despite our confidence that entrepreneurship is now a legitimate field (Baker \& Welter, 2017), we are still relatively young and subject to (re)discovering common issues with which many other fields have previously grappled and with which some continue to grapple. Contextualization is one such issue. While it is central to the fields of social anthropology and linguistics, it also plays an important role in the development of many others, including neuroscience as well as creative fields such as fine arts photography. We have drawn on a few of these fields, in a very limited way, in this monograph. We suggest, however, that there is still a great deal that entrepreneurship researchers can and should learn from a more thoroughgoing attempt to bring additional lessons hard-learned by other disciplines to the context (pun acknowledged) of entrepreneurship research.

Drawing on Whetten (1989), Welter (2011) distinguishes between contextualizing theory and theorizing context. The former is mainly the application of situational and temporal boundaries to theories in entrepreneurship, an activity which drives a great deal of useful comparative research. It is one thing, however, to contextualize our theories by adding this or that control variable or by adding even rich descriptions of research sites. The notion of theorizing contexts focuses, in contrast, on asking broader and more challenging questions of our theories, for example, by resisting the urge to blithely "control" away dynamics that we do not fully understand. Theorizing contexts means developing theory about contextual elements previously largely taken for granted. The drive to theorize contexts can help us discover new insights that are based not just on filling arbitrary oversights and gaps in prior work, but also on addressing patterns and voices that have been systematically downplayed. Theorizing contexts requires the disciplined attempt to ask our theories to address broad-ranging questions regarding who is involved in entrepreneurship as well as where, when, how and why they come to be involved and with what consequences to themselves and to others (Welter 2011). The approach we describe and recommend in this book, the Critical Process Approach, is a way to theorize context driven in large part by an expansive view on the empirical domain of our field (Baker \& Powell, 2019; Welter, Baker, Audretsch, \& Gartner, 2017).

\section{Practical and Logical Challenges}

\section{You Can't Do It All}

Calls to contextualize entrepreneurship research are-if taken to the extreme-vacuous. The opportunity to contextualize our work is apparently unbounded and in comparison, our capacities and resources for doing entrepreneurship research are limited. The drive to contextualize may easily become counterproductive, especially to the extent it takes 
place at the expense of other research goals. For example, everyone reading this is likely to be familiar with papers that claim a contribution based solely on being the first to examine some well-known something or another in some context where it has never been examined before. We are also concerned that demands for contextualization could become blunt tools in the hands of reviewers. "So what"? is often an appropriate response. Contextualization is not a good in itself but should be valued when a researcher-or a critic—can point to a clear rationale for why investing in the contextualization of some stream of research or findings is likely to add value in some specific ways. Contextualization is one of many competing goods in terms of the pursuit of interesting and useful empirical research.

More troubling, in a very broad sense, extreme versions of "contextualizing" or "contextualization" can lead to an infinite regress in which it becomes very unclear what is figure and what is background. As Steyaert (2016) notes, literary and cultural studies have been a prime example of this, with context "an endlessly contested concept, subject to often rancorous rehashing and occasional bursts of sectarian sniper fire" (Felski, 2011, p. 573). In some social science fields, for example, cultural anthropology, the struggle over contextualization has been recognized as equivalent to some of the problems of extreme relativism, allowing scholars few secure places to stand, even temporarily. Scharfstein (1989, p. XI) thus describes "the issue of context" as laying "an intellectual burden on us that we cannot evade but that can become so heavy that it destroys the understanding it was meant to further". In our opinion, some of the excesses of postmodernism also provide fair warning against such relentless attempts to deconstruct scholars' every claim and to value the deconstruction more than that which it takes apart.

In our synthesis of previous work, we showed that entrepreneurship research has experienced not only a deluge of studies that take one or more elements of context into consideration but also an outpouring of essays that examine and proselytize for greater emphasis on context. Taken together, such essays and studies provide some rudiments of an incipient theory of entrepreneurship contexts, including especially a set of frameworks useful for delineating elements of context that need to be taken into consideration. At various points in our attempts to apply some of these frameworks (e.g., Welter, 2011; Zahra \& Wright, 2011), however, it became apparent that it is difficult to classify aspects of contexts into questions of who, why, how, where and when (Baker \& Welter, 2018). For example, who and why often seem largely inseparable, because questions of who I am and who I want to be drive extremely heterogeneous founder motivations (Powell \& Baker, 2014): who and why are thereby inextricably intertwined and attempts to rip them apart are likely to stall progress. Even more broadly, research attempting deeper historical understanding, extending to a variety of ways of 
understanding temporality, requires simultaneous consideration of who, why, how, where and when. Taken as a whole, this work threatens to overwhelm the boundaries of the typology provided by Welter (2011, building on Whetten, 1989) and to reinforce and remind us of the seemingly unbounded problem of context. To use a non-technical term, progress toward the development-still largely implicit—of a theory of entrepreneurship contexts has been somewhat willy-nilly.

To be sure, most entrepreneurship research is currently a long way from any excesses of the drive to contextualize. Implicitly, many of our theories and concepts still assume that entrepreneurship is the same all over the world, regardless of cultural, institutional, social and spatial contexts-in other words: we have managed to create and we still maintain a highly de-contextualized research field, which also influences both our teaching, and the advice we give to entrepreneurs, those supporting them and policymakers. Hjorth, Jones, and Gartner (2008, p. 81) observed that entrepreneurship research has been characterized by a search for "'general laws' of entrepreneurship which might transcend context, and in doing so has been tempted by accounts of entrepreneurship that are removed from context and are thus decontextualized". This remains true not only of much scholarly work but of popular and influential practitioner accounts as well. For example, Brännback and Carsrud (2016) report that even Steve Blank, the inventor of the "lean start-up model", acknowledges the context-specificity of his model, which stems from his experiences as serial technology entrepreneur and investor in Silicon Valley. But we nonetheless repeatedly see it viewed and taught as if it were an easily universalized normative model for creating new organizations.

We are quite sympathetic to the aspiration of Ucbasaran, Westhead, and Wright (2001, p. 68) to contribute to "an integrated, theoretically driven and comprehensive framework" for studying contexts in entrepreneurship. Unfortunately, we believe that such a framework may be beyond our grasp. The experience of other fields attempting to grapple seriously with issue of context is that the infinite regress and the slippery slopes of extreme relativism are forever on the near horizon. Our perspective therefore builds instead on Welter's (2011, p. 177) characterization of the challenge, where she suggests "that a contextualized view on entrepreneurship asks for an interdisciplinary perspective, as the solution cannot be to develop an overarching theory of entrepreneurship in all contexts, but rather working with disciplines like anthropology, sociology, and others, which possess some of the tools and concepts entrepreneurship scholars need to explore the variety, depths and richness of contexts". We are wary of all explanations that present themselves as "the truth" or on some singular path to find it. And we are especially allergic to "contingency" approaches to contextualization that operate-implicitly or explicitly-under the assumption that the purpose of contextualizing is to somehow either to remove or "control for" context in a manner that 
lets very simple universal truths emerge and be stated, or that countlessly complexifies theories by adding strings of contingencies and interactions between them. We applaud instead Steyaert's (2016, p. 33) interpretation that, "After all, the notion of context was invented to turn analysis away from its universalistic ambitions and to overcome the problems of contingency theory-with its quasi-endless series of contingent factors that could interfere with the generalizability of causal relations".

\section{Understanding the Limits of Contextualization Through the Simple-Accurate-General Framework}

It is a scholarly dream that a fully contextualized theory would be simultaneously accurate, simple and general. Unfortunately, we all face unavoidable tradeoffs in the pursuit of these goals. Fortunately, the tradeoffs among these three worthwhile aspirations for theorizing help to provide some structure to our understanding of the limits of contextualizing our theories. Contextualizing can challenge the adequacy of simple, it can challenge beliefs about accuracy, and can throw into stark relief the limits of our claims to generality. Organization scholars are most likely to have learned this lesson from Weick (1979), who credited the underlying ideas to Thorngate, and his "postulate of commensurate complexity". Thorngate (1976) in turn developed these ideas in his commentary on a dialogue between Gergen (1973) and Schlenker (1974). To greatly simplify their arguments: Schlenker was arguing that our theories could make a great many assertions that would be largely unconditionally true across most or all contexts. Gergen was arguing instead that we could say very little that was unconditionally true. Thorngate (1976, p. 405) responded with a kind of synthesis by observing,

"The more conditionals we add to a theory, the more specific and less parsimonious it becomes, approaching the limit of a series of statements each of which describes a single event. (...) At this limit, description and explanation become synonymous. If our explanations are to be more than "mere" descriptions of historical events, then we must determine how many conditionals (variables, parameters) our theories must have in order to give a general, accurate account of social behavior. Will a three-parameter theory suffice? A 27-parameter theory? When can we safely state that a phenomenon occurs 'in general'? When should we add a conditional to describe how 'it depends?'”

Dilley (1999, p. 9) puts this more succinctly, arguing that we are "caught between the Scylla of contextual relativism and the Charybdis of 'extreme sameness and objectivity"'. Earlier, German philosophers and social theorists drew similar contrasts between "nomothetic" explanations that 
generalize across instances and "idiographic" explanations that fully explore particular cases (Campbell, 1975; Dilthey, 1989; Weber, 1978; Windelband, 1893).

In such framings, contextualization creates complexity in the service of accuracy and also in service of the generality of an entire, perhaps quite complex, body of theory. A fully contextualized theory might be a descriptively accurate rendering mirroring rather precisely the features of some social world, capturing a full set of contingencies that might shape the manner in which these features influence whatever outcomes we are interested in explaining. For example, if some factor-let's say the prevalence of malaria-were important in some contexts but not at all in others, a fully contextualized theory would include constructs that fully moderated the impact of this disease. Few entrepreneurship scholars would carry arguments about contextualization to such lengths, and not many have pushed strong versions of relativism, but this debate nicely sets up the question: given that we can't attend to the full multiplicity and heterogeneity of context in our research or theories (Welter 2011), what sorts of context matter most? How do we usefully avoid the potentially unbounded demands of contextualization and instead harness the "contextual turn" in entrepreneurship research in a useful way?

As described in Part I of the book, entrepreneurship researchers have turned to some popular typologies for help in contextualizing their work. Overall, our assessment is that typologies such as those outlined by Zahra and Wright (2011); Zahra, Wright, and Abdelgawad (2014) and by Welter (2011) have served as useful guides. They have helped move contemporary research a little ways away from the too-naïve search for general laws of entrepreneurship regardless of context (Hjorth et al., 2008). Such typologies will continue to remain useful as general checklists indicating dimensions of our research that might benefit from tilting the balance away from simplicity and towards accuracy and perhaps generality. We are increasingly concerned, however, that even such checklists and typologies can rapidly become too complex as briefly outlined in our introductory chapter.

\section{Theorizing Contexts}

As Welter, Baker, and Wirsching (2019) describe it, entrepreneurship research has gone through three waves of contextualization, each challenging a prior balance between simplicity, accuracy and generality, and with the current wave characterized by a drive to expand the empirical reach of our research dramatically. The current drive to treat seriouslyby studying and theorizing-a much wider variety of entrepreneurship defies attempts to defend prior implicit agreements about what is an appropriate balance. Our call for theorizing contexts is part of this wave. As we outlined in the previous section, while there are always trade-offs 
and you can never "have it all", we have no way of predicting what the next balancing point will look like. In the remainder of this chapter, we outline what we label a Critical Process Approach, attempting to show how problematizing, making choices and asking who our research serves might provide a more fluid and dynamic approach to balancing the competing goods of simplicity, accuracy and generality.

\section{Theorizing Contexts as Problematizing}

At the most basic level, we see the process of contextualizing as a means of "problematizing" (sometimes called "troubling") existing work: any delineation of contextual limitations functions as a set of heuristics for decentering taken-for-granted facts and assumptions and thereby challenging specific forms of intellectual (or other) complacency. In many ways, by challenging accepted understandings, contextualization can be a driving force of scientific progress. Importantly, however, we do not see this form of problematizing as a destructive or radically relativizing process that seeks primarily to undermine confidence in our knowledge or understanding. Rather, we see it as part of the process of "constructing opportunities for contribution" (Locke \& Golden-Biddle, 1997). As Locke and Golden-Biddle (1997, p. 1029) showed in their grounded theoretical study of (qualitative) papers in Academy of Management Journal and Administrative Science Quarterly:

“(. . .) [I]n order to establish contribution, organization studies manuscripts must re-present and organize existing knowledge so as to configure a context for contribution that reflects the consensus of previous work. The presence of existing knowledge legitimizes a research area by underscoring the intellectual resources devoted to it and, at the same time, provides a theoretical orientation for present investigations (...) manuscripts must in a sense turn on themselves, subverting or problematizing the very literatures that provide locations and raisons d'etre for the present efforts."

In this sense, the sorts of problematizing that contextualizing processes can achieve are an important part of what entrepreneurship scholars do every day when they convince reviewers and editors that their research makes an interesting contribution. The same holds for Murray Davis' classic (1971, p. 309) paper in which he argues that "[i]nteresting theories are those which deny certain assumptions of their audiences, while non-interesting theories are those which affirm certain assumptions of their audiences". Contextualizing processes are an important means for achieving empirical denial of prevalent scholarly assumptions. Similarly, Alvesson and Sandberg (2011, p. 247) critique the common approach of finding research questions by "gap-spotting" because, they say, this 
"tends to underproblematize existing literature and, thus, reinforces rather than challenges already influential theories". They argue that "contextualism and non-contextualism" (along with other bifurcations) become "important methodological resources to open up and scrutinize assumptions underlying established theories, including, to some extent, the favorite theory of the problematizer" (Alvesson \& Sandberg, 2011, p. 252).

Our main point here is that contextualization is part of a research process in which what we think we know is problematized in ways that let us seek better and more interesting answers. Thus, the approach we hope to develop is, at the most general level, aimed at being critical of underlying assumptions that are routinely taken for granted and which, if examined and challenged more explicitly might therefore lead to novel and interesting findings and theoretical insights. Stated in this way, at such a high level of generality, it's simply a thin description of an important engine and outcome of scientific progress: the revision of assumptions.

\section{Theorizing Contexts as a Matter of Researcher Choice}

Since we can't "have it all" in contextualizing our research, we need to make choices. In a very real sense, researchers "do contexts": they enact them by their own behavioral choices. Researchers live in a world of deeply constrained and embedded agency. This world is structured in part by the prior scholarship upon which they draw both for ideas and in order to position the results of their work as having merit. As Locke and Golden-Biddle (1997) make clear, however, researchers selectively invoke and position the prior literature while constructing their opportunities for contribution. For the purposes of any paper, "the literature" is what the researcher makes it out to be and convinces readers that it is. From this perspective, "context" is primarily determined by the researcher's focus and attention. Moreover, the researcher chooses the object of study, which implies a unit of analysis and thereby renders much of the surrounding activity at lower and higher units of analysis as "context": as implicit, as background, perhaps as "controls" in quantitative work or as elements of case selection in qualitative work (Yin, 2013).

Early in our career, one of the authors had a colleague, who was focused on micro organizational behavior research, insist loudly that everything we (with a somewhat more macro orientation) found interesting was "nothing but context", which he hoped would show up as a relatively small factor in the "error term" of his models. Our argument back to him was that the individual differences about which he "obsessed" were best averaged over in understanding macro organizational behavior. Each of us was both somewhat correct and deeply naïve. Researchers work for universities and research centers that are embedded in sociopolitical realities that shape both who they are and how they behave. Our 
personal biographies, the culture and country we grew up in and the one we work in, scholarly, personal and political commitments, our research communities and whatever is current in our fields all contextualize our work. Overall, the process of problematizing prior work-which is at the center of a process approach to contextualizing research-is in fact already core to the overall project of entrepreneurship research through the choices we make as we try to do interesting and relevant research.

\section{Shaped by Power and Privilege? The Malleable, Ideological Balance Between $S-A-G$}

We readily admit to personal and professional concern with the extreme inequality of entrepreneurial opportunity that we believe can be observed both locally and globally (Baker \& Powell, 2016; Lippmann, Davis, \& Aldrich, 2005; Scott, Dolan, Johnstone-Louis, Sugden, \& Wu, 2012) and with the challenges faced by actors on the bottom of the Lorenz Curve or among those disadvantaged by demographics or the intersection of derogated statuses. The Critical Process Approach we describe is therefore strongly conditioned by misgivings over the potential of our theories to provide ideological backing that supports the status quo-or worse-by treating with equanimity and thus aiding the power and social advantage (whether inherited, ascribed or achieved) of a few extreme outliers while labeling as boring and thereby ignoring everyday entrepreneurs (Welter et al., 2017) and would-be entrepreneurs who face disadvantage or adversity. Because such justifying ideologies tend to be coherent, compelling and reified as normative and largely invisible commonsense (Berger \& Luckmann, 1966), identifying, examining and moving beyond them can require overcoming linked series of objections. These objections may not typically take the form of direct defense of assumptions but rather take the form of trivialization by gatekeepers (that is, editors, reviewers, etc.) of what appear to them to be "uninteresting" questions or research settings.

Resource constraints and adversity are unequally distributed among entrepreneurs, but they are also rampant (Corbett \& Katz, 2013; Welter, Xheneti, \& Smallbone, 2018). It is from this perspective that we are particularly concerned about biases in how, as a community of scholars, we strike the balance between simplicity, accuracy and generalizability in our theories. Our theories are restricted to extraordinarily narrow applicability when we ignore the limited circumstances of most entrepreneurs at most times in most places in favor of trying to develop somewhat accurate and somewhat simple theories that claim generality either by fiat-for example by trying to restrict the domain of what "counts" as the appropriate domain of entrepreneurship research (Shane \& Venkataraman, 2000)—or by reliance on untested beliefs that "things work about the same all over and for everyone" and that the world is somehow 
characterized by something resembling equality of entrepreneurial opportunity (Baker, Gedajlovic, \& Lubatkin, 2005).

The approach we promote is not focused on armchair deconstruction and critique or attacks on the nature of science or scientific knowledge. Unlike the promise of some approaches labeled "critical", we offer no radical epistemology or attacks on positivistic assumptions or challenges to Enlightenment optimism about progress in knowledge and understanding. Instead, the Critical Process Approach is focused on encouraging a much broader range of empirical research, embracing contexts and forms and people and their circumstances that our work has typically ignored (Baker \& Powell, 2019; Welter et al., 2017). Our goal is to challenge existing and new theories of entrepreneurship to become much broader in their empirical scope, which carries strong - and largely unpredictableimplications for generating a new balance between generality, accuracy and simplicity. To address the possibility of assumptions that may be taken for granted because they are intertwined with the status quo and comforting to privileged stakeholders, we start with two related heuristics: who does our research serve? And what are the assumptions that support our pattern of intellectual servitude?

\section{Ask: Who Does Our Research Serve?}

\section{Serving Scholars}

Well, first of all, it serves us: as academics at institutions that value research, most of us are employed - to varying degrees-to produce peerreviewed publications. As a community, we assess one another's work and make decisions about what gets published and thereby help to shape the course of one another's careers at the same time we shape the body of work that develops. Research, as the engine of publication, thereby serves faculty members as the engine of career progress and rewards. As new members of our field are trained, they are educated primarily to build on the existing body of research that has served to drive the careers of their predecessors and colleagues. Indeed, for every generation of scholars, it is first these predecessors, and eventually one's peers, who serve as judge and jury for which research makes it into peer-reviewed journals (Kuhn, 1962). The hierarchical social structure and career incentives of most academic fields create a bias towards conservatism. In this sense, our research serves established members of academic fields, because both the training and the career incentives of new researchers orient them towards honoring and building upon the work of their elders. Indeed, this is reinforced even in the sense that researchers need to orient themselves towards the taken-for-granted assumptions of their predecessors if they are to follow Davis' (1971) guidance to deny (some of) them in order to be interesting. Such conservatism is reinforced when research depends on 
generating grant funding, as the panels that serve as arbiters of government and foundation largesse tend to be drawn from the ranks of the same gatekeepers who maintain the boundaries of journal publication.

Another source of conservatism derives less from the current social structure, power dynamics and individual incentives of science and more from the processes of science considered more generally across time. Early and pioneering researchers who bring particular assumptions into an academic field may be well aware that they are doing so. In clearly argued papers they may sometimes even explicitly state their assumptions. Over time, as these assumptions are incorporated into later workand the original papers are perhaps honored by citations much more often than they are read-this explicitness may be lost. As new researchers learn to take these assumptions for granted as part of what is sometimes called the "paradigm" of the research field (Kuhn, 1962) and as they become not only institutionalized but potentially reified in the sense of appearing as natural objects independent of human construction and choice (Berger \& Luckmann, 1966), the assumptions move from explicitness toward invisibility.

The social structure and incentives of contemporary science can combine with such processes of reification to form a conservative buttress around what then appear as fundamental-but oftentimes effectively hidden-assumptions undergirding a field. Indeed, Kuhn (1962) argued that in fields with strong paradigms, a combination of the accumulation of evidence at odds with existing theories and the retirement or deaths of the defenders of the paradigm may be required for a "paradigm shift" to occur. In so-called pre-paradigmatic or weak paradigm fields, the sets of underlying assumptions are likely to be less coherent and congruent than in more developed fields of science. In addition, change in such fieldsincluding many social sciences-is likely to be less dramatic than Kuhn's descriptions of scientific "revolutions". But the general point remains that important underlying assumptions disappear, get taken for granted and become hard to displace.

\section{Serving Practice}

The second answer is that our research serves-or at least seeks to serve or to give the appearance of serving - practicing entrepreneurs and policymakers who want to find effective ways to support practicing entrepreneurs. When researchers advise policymakers-or depend on them for funding - they risk getting too caught up in questions policymakers deem important, but which may be less interesting theoretically. The extent to which what we provide is actually put to good use by such stakeholders is, of course, highly contested. Frank and Landström (2016, p. 53) argue that "[i]nstitutionalization [of a research field] favours rigour at the cost of relevance, while at the same time rigour promotes the institutionalization 
of research fields". People engaged hands-on in policy and practice may find what is theoretically compelling to researchers to be of little use. There is some evidence of even highly successful management researchers bemoaning the lack of practical relevance of their knowledge. For example, Whittington (2003, p. 122) reflected,

"I have been teaching strategy and organization for about 15 years about I know very little about how to do strategizing and organizing. When called in some small way to help with others' strategy and organization-making, I have hardly anything to say about how they should carry out the actual work of producing new plans and designing new structures".

In a complementary perspective, on academic management research "that matters" to people other than academics, Anita McGahan (2007, p. 751) reflects: "Many of the papers were academically rigoroustypically they were more rigorously researched than those that were successful ultimately. Almost all had compelling messages. The reasons for their failure of impact reflect a range of circumstances, including managerial apathy and complex implications. Yet the most salient common thread was that the papers did not offer managers integrative solutions to relevant and narrowly defined problems".

In contrast, Don Hambrick, one of the world's most influential management researchers, has long held that the knowledge we produce is useful but that we care too little about and do too little to apply it, first criticizing the Academy of Management for failing to celebrate and support practical application and later making the case that we should engage more not just as a professional association but as individuals in shaping practice (Hambrick, 2005). He illustrated this by celebrating an unusual example in which an accomplished management researcher used his expertise to attempt to improve the world (in this case, William Ouchi helping public schools). Extending this to the "field of management's devotion to theory" Hambrick (2007) argues that the theories we honor and defend-and in particular our rejection of research that fails to make a clear theoretical contribution, reduces our ability-relative even to closely-related fields such as marketing and finance-to publish research about surprising and important sets of facts that we may discover. It also reduces or eliminates any incentive to engage in research that starts with practical challenges or quandaries. Hambrick refers to Baker and Pollock's (2007) distinction between theory-driven and theoretically interesting research: they argue that work can be both practically useful and theoretically interesting if it establishes well-wrought opportunities for future theorizing and that such research should be celebrated and published alongside theory-driven work. Comparing research in entrepreneurship to research in strategy, Baker and Pollock (2007) celebrated 
entrepreneurship's greater relative embrace of practically relevant and theoretically interesting research, but worried loudly that this superiority could rapidly dissipate as the field of entrepreneurship matures and takes on the trappings of academic legitimacy through copying closely-related fields.

Barry Staw (1984, p. 87) brings some nuance to this argument by making the distinction between viewing scholarly contributions as being to the "literature" versus being to "advancement in knowledge". His view seems to differ in subtle ways, or at least in semantics, from Hambrick's. In particular, he focuses on the problem of papers being required to make contributions to "the literature", while viewing "theory-driven" to mean something better, perhaps contributing to more of a coherent repository of our understanding of organizations. But he and Hambrick seem to share largely the same frustration: that the potential usefulness of our work-to whatever set of goals and beneficiaries we might embrace-is hampered by professional strictures against taking seriously enough or focusing upon the practical organizational problems that populate the world. Staw (1984, p. 87) argues that "we routinely judge the significance of a research paper by its contribution to the pile of studies already conducted and archived in the journals rather than by its contribution to our understanding of organizations". As a consequence, "[w]hen research is literature- rather than theory-driven, contributions to knowledge are more conservative and incremental than they need to be. Because authors focus more on how their research fits with the previous literature than on the organizational problem itself, their research inevitably becomes directed toward controversies and gaps in the literature rather than toward a fresh look at the issues being studied". The review process, he argues, reinforces this conservatism, in part by requiring greater levels of rigor from papers that communicate results that contradict the existing literature or assumptions embedded in popular theories. In a wry summary, he notes: "If knowledge building is our goal, then the only contributions that are clearly insignificant are those in which we have little interest in the major predictions of the study, regardless of how the data turn out. Unfortunately, into this small category one might place a large proportion of the current literature".

Taken together, these indictments of how little our research seems to affect the world of organizational practice-writ large-describe an "ivory tower" conservatism with regard to what is acceptable as scholarly practice by university researchers in management fields such as entrepreneurship. What we find encouraging, though, is that the questions of what we may contribute and who we are to serve has been a continuous theme, gaining importance again over the past decade as reflected in the growing number of articles, books and editorials on relevance and impact of research, which indicates that scholars have started to care, once more, about the outcomes of their research and the value they may generate for 
entrepreneurs, would-be entrepreneurs, businesses, managers, society or economic development (e.g., Frank \& Landström, 2016; George, 2016; Kieser, Nicolai, \& Seidl, 2015; Landström, Parhankangas, Fayolle, \& Riot, 2017; Van de Ven \& Johnson, 2006; Whitehurst \& Richter, 2018).

But what about the more common-sense concern about the conservatism that might infuse our research to the extent that it actually does serve "practice"? One way of looking at this is to insert a preliminary question before asking who our research serves. To wit: who benefits from the status quo? If we adopt a Panglossian perspective that the way the world of entrepreneurship practice works right now hovers around an ideal situation, mostly needing incremental tweaks and improvements in terms of efficiency and effectiveness, then the question of "who benefits from the status quo" can be answered in terms along the lines of "pretty much the right people". From this view, serving practice means providing tools and knowledge that help those already in positions of privilege, power, authority and influence over new ventures to better accomplish their goals.

\section{Serving Universities}

We have so far left out one key player in this conservative tale: the university itself. It is hard to separate the story of entrepreneurship research from the story of the proliferation of university entrepreneurship programs over the last three decades or so. In the U.S., even as rates of entrepreneurship have plummeted, celebration of entrepreneurship has soared. During the early 1980s, the "discovery" of the link (now both disputed and more nuanced) between entrepreneurship and job creation was quickly glommed onto by policymakers in Europe and the U.S. as something of a panacea for problems of un- and underemployment. Programs to support entrepreneurship proliferated and some of this money found its way to universities and helped to drive the generation of entrepreneurship programs and centers and the at-least-nominal transmogrification of small business-centered activities to "entrepreneurship activities".

Universities also discovered that wealthy entrepreneurs could be a vital source of endowments, as donors sought to memorialize their own successes and attract others to follow in their footsteps. Entrepreneurship went rapidly from a backwater field of research (one of us was told repeatedly by a respected scholar as recently as the mid-1990s: "Don't go into entrepreneurship, nobody ever gets tenured in that at good schools"), to a field with major academic labor shortages and chairs that went unfilled for lack of senior candidates. Coincident with the infusion of money and proliferation of programs, researchers trained as sociologists and psychologists and interested in entrepreneurship migrated to business schools, while others trained in business schools to do strategy and 
organizational behavior research (sometimes uncharitably referred to by old-time entrepreneurship researchers as "carpet-baggers") retooled (or did not) to study entrepreneurship.

As a result of these developments, we argue that even if the management departments that came to house most entrepreneurship researchers did not produce much research that was clearly of practical value to practitioners of any stripe or if they did produce useful knowledge but didn't take steps to bring it to bear in practical ways, the culture and demands of business schools and their benefactors nonetheless shaped entrepreneurship research. There are two parts to this argument. First, business schools are so-called "professional schools", primarily training people to have the knowledge, skills, networks and social behaviors appropriate for success in the corporate environments into which most students are recruited or hired. If you don't believe the latter part of this claim, take a look at the narrow range of attire the men and women enrolled in MBA programs choose (or are required) to wear when encountering recruiters on campus.

Although there have been recent calls for improving the "critical thinking" skills of business school graduates, the meaning of "critical" here is limited and perhaps mostly targeted at skills like those that can contribute to targeted innovations that help their employers meet financial goals. There is little call to train students in more broadly critical thinking. Although it arguably would make sense to teach students aspiring to create highly innovative new ventures to look more skeptically at accepted truths, most business school entrepreneurship students are likewise destined to spend large portions of their careers as employees of established larger companies. Few of these companies are actually looking to hire what we might label deep critical thinkers. Business faculty are, by and large, teaching conservative students conservative perspectives and tools for making their way in the business world. To the extent that business school culture is shaped by the overall gestalt of the teaching demands that faculty face, we expect that the conservatism of preparing students for successful corporate careers is likely also to shape the research that faculty undertake. A shortcut for this might be to say that we would expect more "critical" entrepreneurship research to emanate from sociology-and in some cases even from economics than from management departments.

One such example, where critical thinking has emerged from economics, is the move towards a more pluralistic orientation of economic studies. In Germany, for example, this has been driven by students who were dissatisfied with what they perceived as the model-driven and mechanistic nature of their study subject, too strongly favoring abstract mathematical elegance over engagement with the reality of economies and economic development. This movement gained impetus in the wake of the worldwide financial crisis: students demanded and organized lecture series in economics that offer "other" theoretical and empirical perspectives on economic development—such as heterodox economics, feminist theories, history of 
economic thought, post-growth economics and the like. At the university of one of the authors of this book, this has resulted in a new (and popular) master's degree program in plural economic studies, teaching students "real-world" economics: a wider array of economic theories and different research methods than standard neo-classical economic modelling.

Another such example is the emerging critical discussion around our taken-for-granted assumption that the standard business school modelincluding our approach to entrepreneurship education—should be exported everywhere while also assuming that this transfer requires little or no attention to spatial, cultural and historical contexts. This perspective is perhaps closest to being true if the students we imagine are part of some global, transnational elite that experiences the world in similar ways and derives similar benefits from the status quo. Education and development scholars and those engaged in postcolonial studies have long provided a critical perspective on these sorts of assumptions. Their work illustrates how a critical perspective on the discourse around entrepreneurship education can surface hidden assumptions. Entrepreneurship education for indigenous youth in Canada, for example, has sometimes been built in a manner that blithely accepts the dominant discourses of neoliberalism, including the deficits of the "others" (the indigenous people who are being taught!) and non-indigenous hegemony (Pinto \& Blue, 2016). Academics from other contexts have argued for the need to liberate their business schools from Western influences (Pederzini \& Barraza, 2019, p. 29): "Because in the end, Western theories formed in elite business schools would probably not capture how stitching functions in Pakistan, or how leadership unravels in South Africa, or why the Mexican man/woman starts a 'changarro' on a sidewalk to sell quesadillas instead of a 'legitimate' business".

While there are also institution and power dynamics involved in trying to include other perspective and other voices in our curricula, theories and teaching, a more obvious but still intractable problem is that their voices may be published not only in disciplines we consider far from the business school but also in languages that few of us read (Baker \& Welter, 2015). Nkomo (2015) describes the struggles business schools and higher education organizations in developing countries face trying to serve local needs of businesses and policymakers along with the global demands for research excellence in academia. Darley and Luethge (2019) discuss the challenges involved with accreditation. Pederzini and Barraza (2019) insist that the "others" also need to accept the value of their own backgrounds and experiences instead of only looking to the Western world for generalizable truths. These authors pointedly remind us of the shared value of listening to others instead of mostly trying to apply our models to their countries: "Certainly, in our case study, we were shocked to feel like we were supposed to learn from foreigners, but that they did not seem to think there was much to learn from us. The same call goes to elite business schools opening satellite campuses. Are you doing this 
because you want to be missionaries reducing other cultures, like colonizers did, to 'undeveloped natives' needing to be educated, or are you willing to learn something from those other cultures?” (Pederzini \& Barraza, 2019, p. 30).

All of this underlines our call for contextualizing entrepreneurship research and teaching. Critical discourse such as that displayed here makes us aware of how shared, Western or "Global North" thinking has shaped what we have come to accept as the business school model, with its limited curricula and limited research outreach This should cause us to question not only our relevance to "other" places but also our relevance to and functions within our own societies.

A second argument about business school culture and the demands of benefactors is that they shape the sorts of entrepreneurship business schools glorify and thereby shape, in direct, largely non-theoretical ways, what comes to be seen as interesting research. Almost by definition, the entrepreneurs who provide substantial funding to many entrepreneurship programs and who are sought out by others are financially successful. Given our general tendencies as observers to commit the fundamental attribution error in accounting for such success, combined with the complementary self-serving attributional biases of the successful and reinforced by the usefulness of accepting and building upon such attributions in fundraising, a vision of heroic entrepreneurship often comes to be celebrated as a matter of practice in business schools. The heroic narratives we construct celebrate our donors-and even just successful entrepreneurs brought in as guest lecturers-for having made large amounts of money for themselves and for others and for having created jobs. We typically embed the stories of their paths to success in narratives that suggest their accomplishments were driven primarily by hard work, cleverness and, perhaps, ethical values. Sometimes it is left to an entrepreneur with unusual personal insights to point out the role that luck or good fortune-or the munificent context in which they operated-played in their success. More often this is simply left unsaid.

These sorts of narratives reinforce and are reinforced by complementary popular media portrayals of entrepreneurial success embodied in iconic television shows such as "Dragons' Den" and "Shark Tank" and by unrelenting celebration of those individuals who ride the gazelles and unicorns that seem to dominate most press coverage of entrepreneurship. Even when iconic figures such as Jeff Bezos, Mark Zuckerberg or Elon Musk face media scrutiny and criticism, it more resembles medieval discussions over the degree to which the rights of kings were bequeathed by gods than it does any serious challenge. Steve Jobs' allegedly harsh treatment of employees comes closer to being celebrated as a charming and idiosyncratic element of his genius than as a flaw. This theme is strong enough that leading management scholar and public intellectual Adam Grant (2017) wrote an essay countering it, titled, "Steve Jobs is a 
Rorschach test: To be a good leader, you don't have to be a jerk". The fact that such an essay needed to be written reinforces our understanding of the extent to which we have come to think of successful entrepreneurship as embodied by "self-made" billionaires. Business school entrepreneurship faculty are not immune to common culture and media, our research is not immune to the images and processes of entrepreneurship we teach to our students, and it is also not immune to our interactions with the guest speakers and (potential) financial benefactors with whom we and our students interact.

\section{What Are the Assumptions That Support Our Pattern of Intellectual Servitude?}

Our arguments to this point suggest that, by asking who our research serves, we can uncover how it is shaped by a series of overlapping pressures towards conservatism and also towards focus on particular sorts of entrepreneurs and entrepreneurship that reflect both common cultural themes and the particular sorts of entrepreneurs who typically serve as models for our students and as benefactors for our universities. To overdramatize things only slightly, this question helps us describe some of the contours of the intellectual servitude under which we too often toil. The Critical Process Approach to moving entrepreneurship research forward then becomes a matter of doing interesting research by critically examining the assumptions that support this intellectual servitude. The CPA sets its sights on two primary—and inextricably intertwined—forms of emancipation: the emancipation of entrepreneurship researchers from conservatism in service of a narrow view of what's considered important and interesting and the potential thereby to aid in the emancipation of those entrepreneurs who need to become important elements of a new answer to the question, "who does our research serve"? The good news, we think, is that both forms of emancipation have the same answer: by broadening our empirical contexts to embrace a more expansive and less privileged set of stakeholders, entrepreneurship researchers have the opportunity to emancipate themselves from this conservative form of intellectual servitude through the process of trying to help emancipate other sorts of entrepreneurs- the everyday entrepreneurs who comprise most of the world's entrepreneurial activity.

We do not by any means claim to be inventing something new here. Instead, in the section that follows we will describe, quite briefly, some longstanding and some newer ways that entrepreneurship researchers have already made substantial process and can continue to do so. The Critical Process Approach is alive and well and is serving to decenter what was and has been long taken for granted in entrepreneurship research, and it promises to make our work simultaneously more interesting and more useful. The field of entrepreneurship research has passed through 
prior waves of contextualization (Welter et al., 2019), each of which has to some extent destabilized the overall balance between general, simple and accurate. The Critical Process Approach is characterized by a drive toward vastly expanding the empirical scope of our research, which, unsurprisingly, makes what we knew before seem too simple, not very accurate and hardly general at all. The CPA will result in new balances between simple, general and accurate that later generations of scholars will once again challenge. All such balances should remain tentative if our field is to continue to thrive.

\section{Studying the Other-Gender and Entrepreneurship}

What we mean by the Critical Process Approach is not much in play when researchers just cherry-pick singular assumptions that are ripe for sundering, but instead involves focusing attention more on sets of underlying assumptions that cohere in a manner that creates the potential for systematically limiting the generality or accuracy of our theories. In some cases, this occurs when sets of assumptions support a false image of simplicity or generality by systematically excluding particular sorts of complexity. For example, more than 20 years ago, Baker, Aldrich, and Liou (1997) assessed the state of both journalistic and academic attention to women's entrepreneurship and suggested that women had perhaps gone from being invisible because they were considered unimportant in numbers and economic impact (simplicity through ignoring that which is considered to not matter) to being invisible because they were just like men (generality through treating differences as irrelevant). They argued that such scholarly moves thereby bias the questions that are considered interesting and, therefore, the empirical research we undertake. Even then, there was a rising tide of research on women's entrepreneurship that would wash away much of this apparent yawning complacency (Brush, 1990, 1992; Brush \& Hisrich, 1999).

Fortunately, as we have demonstrated earlier in this volume, the state of affairs they posited has changed rapidly as the flood of empirical research on women's entrepreneurship has turned into a deep reservoir (see, e.g., the overviews by Brush, Carter, Gatewood, Greene, \& Hart, 2003; Brush \& Green, 2016; de Bruin, Brush, \& Welter, 2006, 2007; Greene, Hart, Gatewood, Brush, \& Carter, 2003) that has nurtured profound changes in what we can now see as interesting (Baker \& Welter, 2017; Hughes, Jennings, Brush, Carter, \& Welter, 2012; Jennings \& Brush, 2013). Bringing to bear critical insights about gender and how it plays out both across a wide spectrum of countries, and across an even wider spectrum of women's circumstances, has been a gradual and cumulative undertaking. However, although women entrepreneurs have become more visible over the past decades, their representation in public media and discourse continues to construct a typical feminized picture 
of women's entrepreneurship (Achtenhagen \& Welter, 2003, 2011; Ahl, 2004; Eikhof, Summers, \& Carter, 2013; Ettl, Welter, \& Achtenhagen, 2016; Welter \& Achtenhagen, 2006). Women have become visible but the prevailing image of "normal" entrepreneurship may still be, as Baker et al. (1997) claimed, deeply androcentric.

While a core group of entrepreneurship researchers has worked consistently to drive this project forward, they have been joined not just by a chorus but by a cacophony of voices and perspectives. What could be more exciting for our field? This fits what we envision for a Critical Process Approach: a sustained attempt to identify, examine and challengedriving and building upon empirical research-sets of assumptions that bound current theory. Even with the substantial body of scholarly work on gender and entrepreneurship, this process is hardly complete even now. A great deal of our research continues to see entrepreneurship through an old lens as an activity mainly pursued by men who are motivated primarily or solely by financial profit (Welter et al., 2017).

And indeed, even the classic question of why those women, in the same geographies with similar backgrounds and similar focus on their own wealth creation as their male counterparts, continue to be excluded to such a remarkable degree both from building and from taking leadership roles in growth ventures-and how we might help fix this-remains an important open issue. This has been repeatedly thrown into relief recently in the world of high-technology industries and hot spots (EcheverriCarroll, Oden, Gibson, \& Johnston, 2018). For high-tech female entrepreneurship in established high-tech regions (Silicon Valley, Boston) and in emerging high-tech regions (Washington, Oregon), Mayer (2008) showed that women tended to cluster in female-typed industries even within the high-tech sectors-for example, software publishing, computer systems design services, management and consulting services. Women are also less likely to be accepted into business incubators and accelerators that promote high-tech entrepreneurship (Brush \& Green, 2016; Marlow \& McAdam, 2012). James (2008) suggests that a closer look at the gendered spaces of high-tech entrepreneurship and their resulting inequalities may question the emphasis governments worldwide put on technology-based entrepreneurship as unmitigated positive exemplars for a renewed and future-oriented economy.

Viewing work on gender and entrepreneurship much more broadly, Baker and Welter (2017) bemoaned the fact that some of the most interesting and deeply insightful entrepreneurship research-including that examining gender-has been ghettoized, in the sense that it has remained something of a specialty area, and many of its insights have failed to penetrate the thicket of assumptions protecting traditionally more mainstream work. Tongue only somewhat in cheek, they speculated on how the tides might turn and imagined the current mainstream focus becoming instead a specialized area, suggesting: "This subfield will focus on 
developing theory to explain the behavior of externally financed, nonfamily, profit-focused growth ventures in developed economies, generally started and run by young white men with their eyes on the prize of a lucrative 'exit' event". They suggested that the empirical focus of this subfield would need to be positioned "as a rare special case within a more robust and general framework for building theory about entrepreneurship as it is practiced by most people, in most places and at most times" (Baker \& Welter, 2017, p. 170).

\section{Questioning the Dominant Entrepreneurship Models}

In addition to the rich case of research on gender as an episode in the Critical Process Approach to contextualizing research, a wide variety of other empirical cases severely violate one or more assumptions of the so-called "Silicon Valley Model" and which might therefore offer promising options for theorizing context. Baker and Powell (2019, p. 406) argued in criticism of this model that "[o]ur research still mostly imagines, and any teaching based on it therefore mostly recreates, an image of entrepreneurship as spanning only a rather narrow typology of organizations assumed to be focused on mostly the same narrow sets of ultimate goals-prioritizing financial returns to shareholders-as those we expect large publicly held corporations to pursue (Friedman, 1970)". In what we consider a hopeful development, however, this popular image of entrepreneurship (Aldrich \& Ruef, 2018; Welter et al., 2017) has come to serve as a useful metaphor that nicely symbolizes the narrowness of the swath of entrepreneurship that for too long served as both the default meaning and presumed aspiration in too much of our literature. Many researchers have responded to calls for critical perspectives on the SVM and a cascade of papers has begun to appear (see, for example, Aldrich \& Ruef, 2018; Pahnke \& Welter, 2019; Welter, 2018; Welter et al., 2019), that vividly illustrate the value of studying the heterogeneity and variety of entrepreneurship across and in different contexts as we have outlined in our synthesis.

The term "everyday entrepreneurship" (Welter et al., 2017) has gradually emerged to symbolize the scope of organization creation and nurturing that takes place every day, around the world, by large numbers of people with highly diverse circumstances and goals as Steyaert and Katz (2004, p. 190) describe: "When researchers become blinded by a focus on high-growth firms or business millionaires as the exemplars of 'entrepreneurship', they risk losing sight of the process of entrepreneurship in the larger society", instead suggesting that we pay more attention to the "everydayness of entrepreneurship". Welter et al. (2017) argue that most of this entrepreneurship and by extension the research that focuses on it, has too long been treated as unimportant. While embracing the need for "dichotomies" as a way to start sorting through the complexity of entrepreneurship, they point out that "in entrepreneurship research, this 
process has too often taken the form of invidious distinctions implicitly serving a functionalist notion of entrepreneurship that valorizes economic outcomes of wealth accumulation and job creation as the supreme and often the only goal" (Welter et al., 2017, p. 314). Examples of these invidious distinctions include "opportunity-based" versus "necessitybased", "venture-capital backed versus "bootstrapped", "promoter versus trustee" and so forth. Each of the derogated terms on the right side of the comparison makes up a very substantial proportion of the entrepreneurship we can observe in the world. The move toward yet another dichotomy that seeks to "valorize" everyday entrepreneurship and to pigeonhole the SVM recognizes the importance of deepening our study and theoretical understanding of most entrepreneurship in most places and most times for both practical and theoretical reasons. Illustrating the practical reasons, Welter et al. (2017, pp. 315-316) ask: "What is more useful to the world and to entrepreneurship writ large-some incremental contribution to our understanding of the interactions between entrepreneurs and venture capitalists (that is, by the way, unlikely to ever affect the behavior of either) - or a deeper and engaged understanding of how impoverished female entrepreneurs starting informal ventures in contexts of deep cultural misogyny can improve their chances of survival and generate some degree of autonomy?"

In terms of theory development, Baker and Powell (2016) note that the radically decontextualized focus on the "nexus" of enterprising individuals and lucrative opportunities (Shane \& Venkataraman, 2000) has largely blinded our research to deepening socio-economic inequality and what they call "inequality of entrepreneurial opportunity", leaving us with too limited understanding both of how entrepreneurship is shaped by inequality and also of the possibilities and limits of individuals or collectivities trying to respond to strictures of inequality through entrepreneurship (Baker et al., 2005). They make an argument in favor of reviving Stevenson and Jarillo's (1990, p. 23) definition of opportunity as a future situation which is deemed desirable and feasible as a much more broadly useful characterization than those that have been popularized in entrepreneurship research more recently. Arguably, narrower definitions represent special limited cases of Stevenson and Jarillo's approach and their adoption serves to constrict the empirical scope and vision of our research.

There is something of scholarly fearfulness and shrinking in some of our approaches to delimiting the empirical scope of our field. Coming from traditions of North American and European research, we have been too comfortable seeing entrepreneurship as "other" to the extent that it is distant from one or more dimensions of something resembling the Silicon Valley Model. The authors of this book, along with many other researchers and journal gatekeepers, come from a context in which job creation, technological innovation, reliance on infusions of equity investments and self-made heroic male entrepreneurs are "us". These are intellectually 
safe and "normal" conceptions that few within or outside of the walls of the academy challenge as "not entrepreneurship". The rural, the informal, that which is created by women or the disabled, occurring in peripheral regions or in countries not typically viewed as entrepreneurial or as good sites for new scholarly discoveries, are sorted into so many categories of the "other" and, as is commonplace in such processes, what is "other" comes to be viewed as homogenous and in this case as homogenously boring or irrelevant.

In contrast, we believe that the heterogeneity of the "other" sorts of entrepreneurship provides a rich tableau on what constitutes entrepreneurship and its everydayness in themselves. Baker and Powell (2019) argue that the study and teaching of entrepreneurship are essential enough to what it means to participate fully in contemporary society that entrepreneurship should be considered a "new liberal art". They provide a typology of models of entrepreneurship that violate the assumptions of the SVM and argue that the empirical strictures we have imposed on our research and theorizing render us largely unable to explain or to teach these models. We need to get away from "othering" everything which does not fit our existing models and research interests, and instead start incorporating the wondrous variety of entrepreneurship into our theories and research approaches (Gartner, 2004, 2013). The Critical Process Approach can help us with this.

\section{The Critical Process Approach to Theorizing Contexts and Entrepreneurship}

By actively seeking out the "other", many of the emerging strands of research we touched upon in the previous chapters have given the lie to some of the cherished presumptions of entrepreneurship research. As we have argued (Baker \& Welter, 2017), for example, scholars of gender and entrepreneurship have made some of the most useful and interesting contributions to entrepreneurship research writ large over the past 20 years. New research on women's entrepreneurship has emphasized the detrimental effects of public and policy discourses that construct women entrepreneurs as deficient and less capable in comparison to a (male) norm of entrepreneurship (Ahl \& Nelson, 2015), thus putting the "blame" for their smaller and less-innovative businesses onto the women instead of the gendered contexts in which they are embedded. We suggest that, as researchers, we need be aware not only of the power such discourses have and of their impact, but also of how much (or how little) our own research informs public thinking and discourse.

For example, the Organisation for Economic Cooperation and Development (OECD), together with the European Commission, conducts important work on "missing entrepreneurs" (www.oecd.org/cfe/leed/ inclusive-entrepreneurship.htm); in their own words, "to examinate the 
barriers faced to business creation and self-employment by people who are disadvantaged or under-represented in entrepreneurship activitiesyouth, seniors, the disabled, women, ethnic minorities, the unemployed and others-and the public policy actions that can promote and support these activities". We would like to ask: disadvantaged and underrepresented in relation to who or what? One of us is sitting on the steering committee for that project and knows of the difficulties changing officially accepted language-which may seem a small issue but has wider implications for how we see and represent the entrepreneurship by women, seniors, disabled persons and ethnic minorities as not only missing, but frequently still as deficient. The question we want to ask, and the language we would like to open up, concerns the unexamined assumption that what entrepreneurship means-and the forms it should take-are the same for those currently disadvantaged or excluded as for those who are currently privileged, in terms of engaging in entrepreneurship. It is not at all clear that the models of entrepreneurship built largely by white men are necessarily the best models of entrepreneurship for everyone (or even for all white men!). Such government bodies need to consider both how to remove barriers to participation in entrepreneurship and barriers from finding new ways to engage in entrepreneurship-and to begin paying more attention to what we express through the ways we describe entrepreneurship.

We are excited by the attention increasingly being paid to entrepreneurship in emerging and even struggling socio-economic geographies. Without a doubt, if and when high growth and financially successful ventures with defensible competitive advantages are created in these contexts, they will have important implications for socioeconomic development. But rather than simply searching for these and rendering the everyday entrepreneurship in such contexts as boringly undifferentiated, scholars have begun to engage in close examination and theoretical differentiation. Researchers have, for example, begun to challenge the whole notion of "institutional voids", which is based primarily on what is different in the institutional context from what we might see in the Global North. Attempted policy transfers often operate on these assumptions, attempting to implement what is believed to work in a Western context without much questioning of their interplay with local underlying mechanisms and doctrines, despite research which has shown this to be problematic; for example, in former socialist countries (e.g., Bateman, 2000a; 2000b; Welter \& Smallbone, 2011; Xheneti, 2017; Xheneti \& Kitching, 2011).

Similarly, recent scholarship has also gone beyond the unalloyed celebration of microfinance towards closer and more critical examination of its practices and toward richer theorization of its form and the behaviors and outcomes it induces (Dorado, 2015). Work on "informality" has also become much more nuanced, engaging, for example, in closer examination of why and how founders choose to remain "informal", 
recognizing (to a limited extent) that informal entrepreneurship often makes its own contributions to economic and social development and avoiding the knee-jerk reaction of solely pushing entrepreneurs towards formalizing (e.g., Ketchen, Ireland, \& Webb, 2014; Siqueira, Webb, \& Bruton, 2016; Sutter, Webb, Kistruck, \& Bailey, 2013; Webb, Bruton, Tihanyi, \& Ireland, 2013; Webb, Ireland, \& Ketchen, 2014; Welter \& Smallbone, 2009; Welter, Smallbone, \& Pobol, 2015; Williams, 2004; Williams \& Horodnic, 2015; Williams \& Nadin, 2013; Williams \& Shahid, 2016). The debate around informal entrepreneurship and institutional voids is a good example of how research taking a Critical Process Approach-explicitly and persistently using empirical research to challenge the long-implicit assumptions that privilege the powerful and render the powerless silent-is broadening empirical entrepreneurship research and deepening our theories. So called "institutional voids" in socialist countries for example, supported the institutional freedom for individual actions that governments allowed: during socialism, the socalled second economy, which covered semi-legal, informal, but tolerated activities-in contrast to the illegal economy (Dallago, 1990)—offered opportunities for trading and small-scale entrepreneurial activities. Its "boundaries" frequently changed, following political discourses about liberalising and restricting private ownership and entrepreneurship (Welter, 1996).

All of these developments encompassing, for example, the persistent determination to describe and theorize-in useful ways-the role of gender in entrepreneurship and the growing recognition of the practical importance and theoretical fecundity of studying entrepreneurship in the so-called "Global South", represent to us strands of the emerging Critical Process Approach that we have tried to crystalize here. In terms of the dynamics of balancing Simple-Accurate-General (S-A-G), we think there is strong reason to believe that the simplicity of our theories is shattering before our eyes as researchers reject assumptions of generality and pursue greater accuracy through vastly increased empirical breadth and reach. This represents a repeatable form of development in which our scholarly beliefs and theoretical assumptions are turned once again—or for the first time-into deeply interesting and important empirical questions. Things are likely to get much messier (and to us, more interesting!) before a new balance and perhaps a momentary balancing point is reached. Entrepreneurship is and will remain important and the directions our research takes with therefore remain important. As scientific creativity generates new patterns of generality and simplicity, future generations of scholars will find both the practical and theoretical value of our work to be sorely lacking and will continue to drive the dynamic rebalancing of S-A-G. Underlying all of this potentially, practically and theoretically profound work are, we believe, continuing and deepening questions about who our research serves. 


\section{References}

Achtenhagen, L., \& Welter, F. (2003). Female entrepreneurship in Germany: Context, development and its reflection in German media. In J. E. Butler (Ed.), New perspectives on women entrepreneurs (pp. 71-100). Greenwich, CT: Information Age Publishing.

Achtenhagen, L., \& Welter, F. (2011). Surfing on the ironing board: The representation of women's entrepreneurship in German newspapers. Entrepreneurship \& Regional Development, 23(9-10), 763-786.

Ahl, H. (2004). The scientific reproduction of gender inequality: A discourse analysis of research texts on women's entrepreneurship. Malmö: Liber.

Ahl, H., \& Nelson, T. (2015). How policy positions women entrepreneurs: A comparative analysis of state discourse in Sweden and the United States. Journal of Business Venturing, 30(2), 273-291.

Aldrich, H. E., \& Ruef, M. (2018). Unicorns, gazelles, and other distractions on the way to understanding real entrepreneurship in America. Academy of Management Perspectives, 32(4), 458-472.

Alvesson, M., \& Sandberg, J. (2011). Generating research questions through problematization. Academy of Management Review, 36(2), 247-271.

Baker, T., Aldrich, H., \& Liou, N. (1997). Invisible entrepreneurs: The neglect of women business owners by mass media and scholarly journals in the USA. Entrepreneurship \& Regional Development, 9(3), 221-238.

Baker, T., Gedajlovic, E., \& Lubatkin, M. (2005). A framework for comparing entrepreneurship processes across nations. Journal of International Business Studies, 36(5), 492-504.

Baker, T., \& Pollock, T. G. (2007). Making the marriage work: The benefits of strategy's takeover of entrepreneurship for strategic organization. Strategic Organization, 5(3), 297-312.

Baker, T., \& Powell, E. E. (2016). Let them eat bricolage? Toward a contextualized notion of inequality of entrepreneurial opportunity. In F. Welter \& W. B. Gartner (Eds.), A research agenda for entrepreneurship and context (pp. 41-53). Cheltenham: Edward Elgar.

Baker, T., \& Powell, E. E. (2019). Entrepreneurship as a new liberal art. Small Business Economics, 52(2), 405-418.

Baker, T., \& Welter, F. (2015). Bridges to the future. In T. Baker \& F. Welter (Eds.), The Routledge companion to entrepreneurship (pp. 3-17). London: Routledge.

Baker, T., \& Welter, F. (2017). Come on out of the ghetto, please: Building the future of entrepreneurship research. International Journal of Entrepreneurial Behaviour \& Research, 23(2), 170-184.

Baker, T., \& Welter, F. (2018). Contextual entrepreneurship: An interdisciplinary perspective. Foundations and Trends in Entrepreneurship, 14(4), 357-426.

Bateman, M. (2000a). Business support centres in the transition economies: Progress with the wrong model. Small Enterprise Development, 11(2), 50-59.

Bateman, M. (2000b). Neo: Liberalism, SME development and the role of business support centres in the transition economies of central and Eastern Europe. Small Business Economics, 14(4), 275-298.

Berger, P. L., \& Luckmann, T. (1966). The social construction of reality: A treatise in the sociology of knowledge. New York, NY: Doubleday and Company. 
Brännback, M., \& Carsrud, A. (2016). Understanding entrepreneurial cognitions through the lenses of context. In F. Welter \& W. B. Gartner (Eds.), A research agenda on entrepreneurship and context (pp. 16-27). Cheltenham: Edward Elgar.

Brush, C. G. (1990). Women and enterprise creation: Barriers and opportunities. In OECD (Ed.), Enterprising women (pp. 37-57). Paris: OECD.

Brush, C. G. (1992). Research on women business owners: Past trends, a new perspective and future directions. Entrepreneurship Theory and Practice, 16(4), 5-30.

Brush, C. G., Carter, N., Gatewood, E. J., Greene, P., \& Hart, M. M. (2003). The Diana project: Women business owners and equity capital: The myths dispelled. Kansas City, MO: Kauffman Foundation.

Brush, C. G., \& Green, P. (2016). Closing the gender gap in entrepreneurship: A new perspective on policies and practices: White paper prepared for the Organization of Economic Cooperation and Development. Paris: OECD.

Brush, C. G., \& Hisrich, R. D. (1999). Women-owned businesses: Why do they matter? In Z. J. Acs (Ed.), Are small firms important? (pp. 111-127). Boston, MA: Kluwer.

Campbell, D. T. (1975). Degrees of freedom and the case study. Comparative Political Studies, 8(2), 178-193.

Corbett, A. C., \& Katz, J. A. (Eds.). (2013). Entrepreneurial resourcefulness: Competing with constraints. Bingley: Emerald Group Publishing Limited.

Dallago, B. (1990). The irregular economy: The "underground" economy and the "black" labour market. Aldershot: Gower.

Darley, W. K., \& Luethge, D. J. (2019). Management and business education in Africa: A post-colonial perspective of international accreditation. Academy of Management Learning \& Education, 18(1), 99-111.

Davis, M. S. (1971). That's interesting: Towards a phenomenology of sociology and a sociology of phenomenology. Philosophy of the Social Sciences, 1(2), 309-344.

de Bruin, A., Brush, C. G., \& Welter, F. (2006). Introduction to the special issue: Towards building cumulative knowledge on women's entrepreneurship. Entrepreneurship Theory and Practice, 30(5), 585-593.

de Bruin, A., Brush, C. G., \& Welter, F. (2007). Advancing a framework for coherent research on women's entrepreneurship. Entrepreneurship Theory and Practice, 31(3), 323-339.

Dilley, R. (1999). The problem of context. In R. Dilley (Ed.), The problem of context (pp. 1-46). Oxford; New York, NY: Berghahn Books.

Dilthey, W. (1989). Selected works. In R. A. Makkreel \& F. Rodi (Eds.), Vol. I: Introduction to the human sciences. Princeton, NJ: Princeton University Press.

Dorado, S. (2015). Microfinance reimagined: Personal banking for the poor. In T. Baker \& F. Welter (Eds.), The Routledge companion to entrepreneurship (pp. 179-192). London: Routledge.

Echeverri-Carroll, E. L., Oden, M. D., Gibson, D. V., \& Johnston, E. A. (2018). Unintended consequences on gender diversity of high-tech growth and labor market polarization. Research Policy, 47(1), 209-217.

Eikhof, D. R., Summers, J., \& Carter, S. (2013). Women doing their own thing: Media representations of female entrepreneurship. International Journal of Entrepreneurial Behaviour \& Research, 19(5), 547-564. 
Ettl, K., Welter, F., \& Achtenhagen, L. (2016). Das 21. Jahrhundert ist weiblich: Unternehmerinnen in der Presse. IfM-Materialien: 249. Bonn: IfM Bonn.

Felski, R. (2011). Context stinks. New Literary History, 42(4), 573-591.

Frank, H., \& Landström, H. (2016). What makes entrepreneurship research interesting? Reflections on strategies to overcome the rigour: Relevance gap. Entrepreneurship \& Regional Development, 28(1-2), 51-75.

Friedman, M. (1970). The social responsibility of business is to increase its profits. The New York Times Magazine, 13, 32-33.

Gartner, W. B. (2004). Achieving critical mess in entrepreneurship scholarship. In J. A. Katz \& D. Shepherd (Eds.), Corporate entrepreneurship (pp. 199-216). Amsterdam: Elsevier.

Gartner, W. B. (2013). Creating a community of difference in entrepreneurship scholarship. Entrepreneurship \& Regional Development, 25(1-2), 5-15.

George, G. (2016). Management research in AMJ: Celebrating impact while striving for more. Academy of Management Journal, 59(6), 1869-1877.

Gergen, K. J. (1973). Social psychology as history. Journal of Personality and Social Psychology, 26(2), 309-320.

Grant, A. (2017). Steve jobs is a Rorschach test: To be a good leader, you don't have to be a jerk. Quartz. Retrieved from https://qz.com/1017491/adamgrant-explains-why-you-dont-need-to-be-an-jerk-like-steve-jobs-to-be-a-goodleader/

Greene, P. G., Hart, M. M., Gatewood, E. J., Brush, C. G., \& Carter, N. M. (2003). Women entrepreneurs: Moving front and center: An overview of research and theory. Coleman White Paper Series, 3, 1-47.

Hambrick, D. C. (2005). Venturing outside the monastery. Academy of Management Journal, 48(6), 961-962.

Hambrick, D. C. (2007). The field of management's devotion to theory: Too much of a good thing? Academy of Management Journal, 50(6), 1346-1352.

Hjorth, D., Jones, C., \& Gartner, W. B. (2008). Introduction for recreating/recontextualising entrepreneurship. Scandinavian Journal of Management, 24(2), 81-84.

Hughes, K. D., Jennings, J. E., Brush, C., Carter, S., \& Welter, F. (2012). Extending women's entrepreneurship research in new directions. Entrepreneurship Theory and Practice, 36(2), 1-14.

James, A. (2008). Gendered geographies of high-tech regional economies. Geography Compass, 2(1), 176-198.

Jennings, J. E., \& Brush, C. G. (2013). Research on women entrepreneurs: Challenges to (and from) the broader entrepreneurship literature? The Academy of Management Annals, 7(1), 663-715.

Ketchen, D. J., Ireland, R. D., \& Webb, J. W. (2014). Toward a research agenda for the informal economy: A survey of the strategic entrepreneurship journal's editorial board. Strategic Entrepreneurship Journal, 8(1), 95-100.

Kieser, A., Nicolai, A., \& Seidl, D. (2015). The practical relevance of management research: Turning the debate on relevance into a rigorous scientific research program. The Academy of Management Annals, 9(1), 143-233.

Kuhn, T. (1962). The structure of scientific revolutions. Chicago, IL: University of Chicago Press.

Landström, H., Parhankangas, A., Fayolle, A., \& Riot, P. (Eds.). (2017). Challenging entrepreneurship research. London; New York, NY: Routledge. 
Lippmann, S., Davis, A., \& Aldrich, H. E. (2005). Entrepreneurship and inequality. In L. Keister (Ed.), Entrepreneurship (pp. 3-31). Bingley: Emerald Group Publishing Limited.

Locke, K., \& Golden-Biddle, K. (1997). Constructing opportunities for contribution: Structuring intertextual coherence and problematizing in organizational studies. Academy of Management Journal, 40(5), 1023-1062.

Marlow, S., \& McAdam, M. (2012). Analyzing the influence of gender upon high-technology venturing within the context of business incubation. Entrepreneurship Theory and Practice, 36(4), 655-676.

Mayer, H. (2008). Segmentation and segregation patterns of women-owned hightech firms in four metropolitan regions in the United States. Regional Studies, 42(10), 1357-1383.

McGahan, A. M. (2007). Academic research that matters to managers: On zebras, dogs, lemmings, hammers, and turnips. Academy of Management Journal, 50(4), 748-753.

Nkomo, S. M. (2015). Challenges for management and business education in a developmental state: The case of South Africa. Academy of Management Learning \& Education, 14(2), 242-258.

Pahnke, A., \& Welter, F. (2019). The German Mittelstand: Antithesis to Silicon Valley entrepreneurship? Small Business Economics, 52(2), 345-358.

Pederzini, G. D. A., \& Barraza, M. F. S. (2019). Just let us be: Domination, the postcolonial condition and the global field of business schools. Academy of Management Learning \& Education. Online early. doi:10.5465/ amle.2018.0116

Pinto, L. E., \& Blue, L. E. (2016). Pushing the entrepreneurial prodigy: Canadian aboriginal entrepreneurship education initiatives. Critical Studies in Education, 57(3), 358-375.

Powell, E. E., \& Baker, T. (2014). It's what you make of it: Founder identity and enacting strategic responses to adversity. Academy of Management Journal, 57(5), 1406-1433.

Scharfstein, B. A. (1989). The dilemma of context. New York, NY: New York University Press.

Schlenker, B. R. (1974). Social psychology and science. Journal of Personality and Social Psychology, 29(1), 1-15.

Scott, L., Dolan, C., Johnstone-Louis, M., Sugden, K., \& Wu, M. (2012). Enterprise and inequality: A study of Avon in South Africa. Entrepreneurship Theory and Practice, 36(3), 543-568.

Shane, S., \& Venkataraman, S. (2000). The promise of entrepreneurship as a field of research. Academy of Management Review, 25(1), 217-226.

Siqueira, A. C. O., Webb, J. W., \& Bruton, G. D. (2016). Informal entrepreneurship and industry conditions. Entrepreneurship Theory and Practice, 40(1), 177-200.

Staw, B. M. (1984). Repairs on the road to rigor and relevance: Some unexplored issues in publishing organizational research. In L. L. Cummings \& P. J. Frost (Eds.), Publishing in the organizational sciences (pp. 85-97). Thousand Oaks, CA: Sage.

Stevenson, H. H., \& Jarillo, J. C. (1990). A paradigm of entrepreneurship: Entrepreneurial management. Strategic Management Journal, 11, 17-27. 
Steyaert, C. (2016). After context. In F. Welter \& W. B. Gartner (Eds.), A research agenda for entrepreneurship and context (pp. 28-53). Cheltenham: Edward Elgar.

Steyaert, C., \& Katz, J. A. (2004). Reclaiming the space of entrepreneurship in society: Geographical, discursive and social, dimensions. Entrepreneurship \& Regional Development, 16(3), 179-196.

Sutter, C. J., Webb, J. W., Kistruck, G. M., \& Bailey, A. V. G. (2013). Entrepreneurs' responses to semi-formal illegitimate institutional arrangements. Journal of Business Venturing, 28(6), 743-758.

Thorngate, W. (1976). "In general" vs. "it depends": Some Comments of the Gergen-Schlenker debate. Personality and Social Psychology Bulletin, 2(4), 404-410.

Ucbasaran, D., Westhead, P., \& Wright, M. (2001). The focus of entrepreneurial research: Contextual and process issues. Entrepreneurship Theory and Practice, 25(4), 57-80.

Van de Ven, A. H., \& Johnson, P. E. (2006). Knowledge for theory and practice. Academy of Management Review, 31(4), 802-821.

Webb, J. W., Bruton, G. D., Tihanyi, L., \& Ireland, R. D. (2013). Research on entrepreneurship in the informal economy: Framing a research agenda. Journal of Business Venturing, 28(5), 598-614.

Webb, J. W., Ireland, R. D., \& Ketchen, D. J. (2014). Toward a greater understanding of entrepreneurship and strategy in the informal economy. Strategic Entrepreneurship Journal, 8(1), 1-15.

Weber, M. (1978). Economy and Society 2 vols. G. Roth \& C. Wittich (Eds.), Berkeley, CA: University of California Press.

Weick, K. E. (1979). The social psychology of organizing (2nd ed.). Reading, MA: Addison-Wesley.

Welter, F. (1996). Unternehmer in Osteuropa. Berliner Debatte INITIAL(3), 100-107.

Welter, F. (2011). Contextualizing entrepreneurship: Conceptual challenges and ways forward. Entrepreneurship Theory and Practice, 35(1), 165-184.

Welter, F. (2018). The Mittelstand: A specific entrepreneurial profile of the social market economy. Journal for Markets and Ethics, 6(1), 99-106.

Welter, F., \& Achtenhagen, L. (2006). Unternehmerinnenbild und Unternehmerinnenidentität. In A. D. Bührmann, K. Hansen, M. Schmeink, \& et al. (Eds.), Das Unternehmerinnenbild in Deutschland (pp. 73-100). Münster: LitVerlag.

Welter, F., Baker, T., Audretsch, D. B., \& Gartner, W. B. (2017). Everyday entrepreneurship: A call for entrepreneurship research to embrace entrepreneurial diversity. Entrepreneurship Theory and Practice, 41(3), 311-321.

Welter, F., Baker, T., \& Wirsching, K. (2019). Three waves and counting: The rising tide of contextualization in entrepreneurship research. Small Business Economics, 52(2), 319-330.

Welter, F., \& Smallbone, D. (2009). The emergence of entrepreneurial potential in transition environments: A challenge for entrepreneurship theory or a developmental perspective? In D. Smallbone, H. Landström, \& D. Jones-Evans (Eds.), Entrepreneurship and growth in local, regional and national economies: Frontiers in European entrepreneurship research (pp. 339-353). Cheltenham: Edward Elgar.

Welter, F., \& Smallbone, D. (Eds.). (2011). Handbook of research on entrepreneurship policies in central and Eastern Europe. Cheltenham: Edward Elgar. 
Welter, F., Smallbone, D., \& Pobol, A. (2015). Entrepreneurial activity in the informal economy: A missing piece of the entrepreneurship jigsaw puzzle. Entrepreneurship \& Regional Development, 27(5-6), 292-306.

Welter, F., Xheneti, M., \& Smallbone, D. (2018). Entrepreneurial resourcefulness in unstable institutional contexts: The example of European Union borderlands. Strategic Entrepreneurship Journal, 12(1), 23-53.

Whetten, D. A. (1989). What constitutes a theoretical contribution? Academy of Management Review, 14(4), 490-495.

Whitehurst, F., \& Richter, P. (2018). Engaged scholarship in small firm and entrepreneurship research: Grappling with Van de Ven's diamond model in retrospect to inform future practice. International Small Business Journal, 36(4), 380-399.

Whittington, R. (2003). The work of strategizing and organizing: For a practice perspective. Strategic Organization, 1(1), 117-125.

Williams, C. C. (2004). The myth of marketization: An evaluation of the persistence of non-market activities in advanced economies. International Sociology, 19(4), 437-449.

Williams, C. C., \& Horodnic, I. A. (2015). Self-employment, the informal economy and the marginalisation thesis: Some evidence from the European Union. International Journal of Entrepreneurial Behavior \& Research, 21(2), 224-242.

Williams, C. C., \& Nadin, S. J. (2013). Beyond the entrepreneur as a heroic figurehead of capitalism: Re-representing the lived practices of entrepreneurs. Entrepreneurship \& Regional Development, 25(7-8), 552-568.

Williams, C. C., \& Shahid, M. S. (2016). Informal entrepreneurship and institutional theory: Explaining the varying degrees of (in)formalization of entrepreneurs in Pakistan. Entrepreneurship \& Regional Development, 28(1-2), 1-25.

Windelband, W. (1893). A history of philosophy. New York, NY: MacMillan Company.

Xheneti, M. (2017). Contexts of enterprise policy-making: An institutional perspective. Entrepreneurship \& Regional Development, 29(3-4), 317-339.

Xheneti, M., \& Kitching, J. (2011). From discourse to implementation: Enterprise policy development in postcommunist Albania. Environment and Planning C: Government and Policy, 29(6), 1018-1036.

Yin, R. K. (2013). Case study research: Design and methods. Thousand Oaks, CA: Sage.

Zahra, S. A., \& Wright, M. (2011). Entrepreneurship's Next Act. Academy of Management Perspectives, 25(4), 67-83.

Zahra, S. A., Wright, M., \& Abdelgawad, S. G. (2014). Contextualization and the advancement of entrepreneurship research. International Small Business Journal, 32(5), 479-500.

\section{Website}

Retrieved 22 July 2019, from www.oecd.org/cfe/leed/inclusive-entrepreneurship. htm 


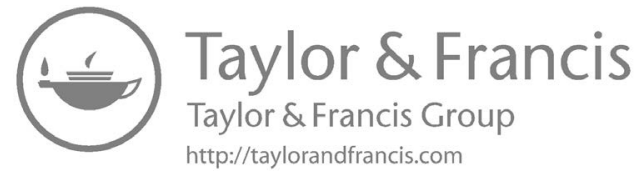




\section{Part III}

Studying Contexts 


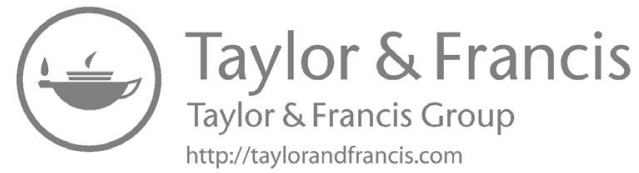




\section{Some Heuristics for Researchers Embracing a Critical Process Approach}

In the previous chapter, we noted that " $[\mathrm{t}]$ he CPA (...) is critical because it takes practical and moral issue with the contours of power and privilege that channel who our research serves; it is a process because it recognizes that the attempt to open up to scrutiny and dismantle any reified assumption that serve powerful interests needs to be sustained and joined by multiple researchers; it is an approach, rather than a technique, because it does not by itself provide satisfying answers of the "do this and things will get better' variety". In this chapter, we will introduce some of the heuristics that researchers can draw upon when applying the CPA.

\section{Some Challenges in Getting Critical Voices Heard}

Part of the problem with getting critical voices to be heard relates directly to the intellectual development of our field and to its resulting legitimacy among those who shape its reward structure. For much of its modern history, the state of the art of entrepreneurship research was characterized by relatively weak theory development and lack of methodological sophistication (Aldrich, 1992; Aldrich \& Baker, 1997). We suspect that the quality of theory development has increased during the last couple of decades, but we are more confident that the level of methodological sophistication has escalated fairly quickly. As entrepreneurship papers have made their way into the most elite general management journals and as entrepreneurship journals themselves have risen rapidly in the overall management journal rankings, the methods we use have come to look more like the methods required in other management disciplines and social sciences. It is increasingly common to see structural equation models, Fuzzy Set Qualitative Comparative Analysis (for an overview, see Kraus, Ribeiro-Soriano, \& Schüssler, 2018), well-designed experiments (see the review by Hsu, Simmons, \& Wieland, 2017) and sometimes even biological or neurological measurements and methods (e.g., de Holan, 2014; Guillory, Boardman, \& Day, 2017; Nicolaou \& Shane, 2014; Treffers, 2017) as well as qualitative methods that match the state of the art in sister disciplines appearing in entrepreneurship papers (for 


\section{Studying Contexts}

an overview, see the handbook edited by Neergaard \& Leitch, 2015). As part of this process, it is not surprising that editors and reviewers have increased the standards they apply in judging the adequacy of the empirics in entrepreneurship papers submitted to leading journals. In some ways, the obvious response to this development is "bravo"!

But there is a downside to the intertwined processes of methodological sophistication and legitimation. While early entrepreneurship researchers were able to develop their ideas in what we might label a "permissive" environment sheltered from the rigors of cutting-edge methodological judgments (while understanding that tenure committees might not indulge them as much as journal gatekeepers would), those who enter the field now are held immediately to higher methodological standards. Because many pioneering entrepreneurship researchers had hands-on experience as entrepreneurs or working closely with entrepreneurs, the relatively loose selection environment for publication allowed them to bring ideas deeply informed by entrepreneurial practice into our journals. The search for legitimacy through narrowing the domain of what was considered interesting (Fayolle, Landström, Gartner, \& Berglund, 2016; Shane \& Venkataraman, 2000; Welter, Baker, Audretsch, \& Gartner, 2017) and increasing methodological sophistication has reduced the access of "the voice of the entrepreneur" - as envisioned by early researchers-to our journals. It has also limited access to the voices of different kinds of entrepreneurs, beyond those known or imagined by early researchers, in our journals. More generally, part of the processes of legitimacy-seeking for entrepreneurship research and of the related trade-offs between "rigor and relevance" (Frank \& Landström, 2016) has therefore been a narrowing of the methodological window for bringing in new ideas. Building on this theme of hearing voices (in a good way!) in entrepreneurship research, as we try to get some traction in thinking about approaches for the CPA, we start by thinking about the voices of those whom our research typically has not focused on serving. We see three primary patterns of not hearing their voices:

1. Including them as silent participants.

2. Disparaging them as "other" and excluding them as uninteresting or unimportant.

3. Rendering them invisible.

\section{Including Them as Silent Participants}

Researchers often do context by "controlling" it away statistically. "Control" variables are typically included in order to show that alternative explanations don't hold. For example, if one were trying to proffer an explanation based on religion and if race and religion were known to be causally related and therefore correlated in some way, one might include a "control" variable for race, while considering religion an "independent" 
(technically, control variables are also independent) or "theoretical" variable. Often, researchers have taken an approach of "and I've thrown in a lot of control variables in an attempt to account for any other explanation a critic might come up with", but recently, there has been some pressure to provide justification for the inclusion of controls (Schjoedt $\&$ Bird, 2014). Control variables are useful for bounding contexts in order to build a statistical model. Their presence also leads to a simple way to identify assumptions that might be usefully questioned.

For a hypothetical example, imagine that one were to review a number of papers on university scientists attempting commercialization of technologies coming from their labs. One might notice that many of these papers either study only men, put in a dummy variable for sex or ignore the whole issue of women scientists. If the research is being done in a place in which men are more likely than women to enter STEM fields in college, more likely to stay in those fields, more likely to pursue graduate STEM education, more likely to finish, more likely to become faculty and more likely to engage in commercialization activities while faculty, any of these approaches might be reasonable simply because the vast majority of one's sample is men. But how much more interesting would it be to understand the reason for the gender differentials at each stage, to know whether the structures and processes that generate the differentials are the same throughout or differ as one progresses or even just why and how women and men (and any other gender) might have differing experiences leading them to engage in commercialization attempts and different experiences once they start. If STEM education and career paths privilege men over women, and most of our research reflects this by studying and building theory about men scientists, then a Critical Process Approach would suggest: "let's go study some women"!

Indeed, while the example we just made up to illustrate this started with examining "control variables", the reason for this is because to include a control variable is at least an acknowledgement that something that may be important exists. When someone-or their characteristics-are represented by a control variable, they become a silent participant. If one examines a body of literature and finds some personal or demographic characteristic is repeatedly reduced to a control variable—and even more so if the controls are typically "dummy" variables-it may be a good sign that there is some taken-for-granted assumption ripe for you to challenge by attempting to give voice to the silent participants.

The problem of silenced voices is hardly limited to "quantitative" theorytesting research. Qualitative research often relies on "key informants", individuals who are presumed to be knowledgeable about the things the researcher wants to know. Overwhelmingly, key informants are people in positions of power and privilege within the organizations researchers are studying; indeed, this often is part and parcel of the reason they are viewed as "well-informed". Moreover, a great deal of contemporary qualitative 


\section{Studying Contexts}

organizational research depends on "semi-structured interviews" with key informants, forgoing opportunities to interact with less senior people or to engage in participant or other observation (Baker, Powell, \& Fultz, 2017). Try this test for yourself: in the next 10 qualitative entrepreneurship papers you read, pay attention to how often there is little or no observation of physical or social context and near-complete reliance on the voice of a person (often a white man) in a position of ownership or authority. Similar patterns, of course, appear in more applied policy work, when the practitioner "experts" invited to the table as key informants overwhelmingly are those already privileged by the status quo, because they are more "accomplished", "educated", "thoughtful" or "informed."

Just as informants frequently end up being treated as "abstract, disengaged tellers of truths in their questionnaire responses", they also end up being seen as "romantic revealers of genuine experiences in interviews" (Alvesson \& Kärreman, 2000, p. 154). In qualitative research, too often we allow a single informant to speak for everyone and for their voice to be the primary source of data. This becomes an important issue for a CPA in particular because the wise voice of the key informant is very typically the voice of those privileged by the contexts in which our studies take place. Baker (2007) played with this in his analysis of the "Toy Story", by giving voice to people who were characterized by others but remained otherwise silent in the narrative, including "Bill Gartner", and the wives of the founders who serve as protagonists. Work in some sister fields has recognized this problem for more than three decades. For example, Preston (1995, p. 942) argued that we are not capable of understanding the "others" because we continue to study their concerns through our "theoretical language, assuming that such language "can pass as the discursive voice of all" whilst adding literature, novels, poems to our language repertoire might bring us closer to the "voices of the margin". There also is a wider language issue which may impact on access to the silent participants. English has become something of our lingua franca. Whilst its increasing use certainly facilitates worldwide communication between researchers, it also may render those of us who are non-native speakers somewhat speechless, as we lose our ability to "develop ideas to full substance and to point out all subtleties" (Welter \& Lasch, 2008, p. 246). On a more positive note, our increasing global research field will allow us to add a variety of silent voices from many different contexts, provided we acknowledge that their voicing may be different from what one would expect from a native English speaker.

\section{Disparaging Them as "Other" and Excluding Them as Uninteresting or Unimportant}

There are many different reasons why some sorts of entrepreneurs or entrepreneurship haven't been studied. Perhaps researchers just haven't had the time or resources to do the work. Perhaps there has simply been 
little a priori reason to expect that studying the entrepreneurial orientation of three-year old start-ups with seven employees in South Dakota or of a small service business in Mongolia will provide new insights, so it hasn't been done or reviewers have decided it shouldn't be published. Much research doesn't get done because mentors are aware that it would entail a risky career path for their doctoral students (although some faculty take the opposite tack, applauding maverick students, see Smith \& Anderson, 2007).

Particularly useful for constructing a CPA is when people have been excluded because they and their kind fall on the wrong side of one of the invidious distinctions between presumed interesting and presumed uninteresting entrepreneurship which are rife in our field. Welter et al. (2017, p. 314) described a series of such distinctions as structuring much of the commonsense assumptions that guide our work:

"[O]pportunity versus necessity-based
venture capital based versus bootstrapped
formal versus informal
men-owned versus women-owned
innovator versus replicator
promoter versus trustee
growth-oriented versus lifestyle
entrepreneur versus small business owner/proprietor
(...) and so on".

After first cataloguing some of the many ways these distinctions restrict scholarly progress, the authors expressed optimism, because the focus on the left side of these distinctions is not hegemonic and entrepreneurship from the right-hand side is getting increased attention. As we have described earlier, this is particularly true regarding work on entrepreneurship under resource constraints and on informality. Other than the men versus women distinction, of course, "the categories on the right represent most entrepreneurship in the world" (Welter et al., 2017, p. 314). This leads to a simple inference: the invisible and silenced entrepreneurs and ventures that the CPA might usefully seek out for empirical study are not that hard to find; they are the mainstream everyday entrepreneurs that we find anywhere and everywhere. Entrepreneurship researchers embracing a CPA are therefore in many ways like the proverbial kid in a candy shop, they need only find a favorite flavor on which to focus first.

Welter et al. (2017, p. 315) noted that the invidious distinctions they catalogued "enshrined simplistic economic goals as the primary functionalist imperatives of entrepreneurship and therefore of our research" despite strong evidence "that the primary motivations behind most venture creation do not match the functionalist economic teleology of wealth accumulation and job creation". This suggests that one fruitful CPA path 


\section{Studying Contexts}

will be to focus on exploring differences between the reasons that policymakers (and the funders and administrators influenced by them) find potential outcomes of entrepreneurship attractive and the reasons that founders actually engage in entrepreneurship. As we have mentioned in earlier chapters, during the last couple of decades, work on gender, work on family business, work on informal sector entrepreneurship and, perhaps most especially, the emergence of social entrepreneurship as a subfield have opened our eyes to the heterogeneity of motivations that animate entrepreneurs. The most recent and promising entry in this process is the rapidly growing body of research on "founder identity", which ties motivations and behavior to the richly textured and multidimensional differences in entrepreneurs' identities.

We find it hard to imagine a robust theory of entrepreneurship that does not acknowledge the profound heterogeneity of motivations, does not document the heterogeneity, offer explanations for it, show how it shows up in behavior or how this affects a variety of interesting outcomes. An important and useful CPA heuristic is therefore to ask, "who among entrepreneurs is motivated by reasons that have been ignored or disparaged in prior research"? In our view, another low-hanging fruit here is research on so-called "necessity" entrepreneurship. There are plenty of conceptual problems with how this term has been used, starting with the researchers who seem not to understand that the "necessity" versus "opportunity" directly describes circumstance, rather than personal characteristics. Those whose circumstances are rich in opportunities are categorized as opportunity entrepreneurs and those whose circumstances are poor in opportunities are categorized as necessity entrepreneurs. There is nothing particularly wrong with calling someone engaged in necessity entrepreneurship a necessity entrepreneur, but it is a profound mistake and a grave impediment to our understanding of context to essentialize them as such, rendering their behavior a function of personal characteristics rather than circumstance. Related to this, and equally troubling, has been our tendency to lumping all "necessity entrepreneurs" together as homogenously uninteresting. Delicious opportunities to challenge and contextualize mainstream assumptions involve empirical investigations of the nature, sources and outcomes of the differences among people engaged in necessity entrepreneurship. This work has begun, particularly in studies of resource constraint and informality (e.g., Dencker, Bacq, Gruber, \& Haas, 2019; Rosa, Kodithuwakku, \& Balunywa, 2006; Smallbone \& Welter, 2003; Williams \& Williams, 2014), but the candy shop remains almost fully stocked.

\section{Rendering Them Invisible}

What has recently been labeled the "Silicon Valley Model of Entrepreneurship" (Aldrich \& Ruef, 2018; Welter, Baker, \& Wirsching, 2019) is 
arguably the archetype of the dominant assumptions that have shaped entrepreneurship research in recent decades (see Aldrich \& Ruef, 2018 for some quantification). It embraces and incorporates the full "left-hand side" of the list of each of the invidious distinctions listed previously, which also provides some cues regarding who such research serves. In arguing for the teaching — and therefore the requisite study—of a much more heterogeneous set of entrepreneurs and ventures, Baker and Powell (2019, p. 411) developed the rudiments of a "typology of non-Silicon Valley Model entrepreneurship" and invited other researchers to add to it. The typology lists a set of Silicon Valley Model assumptions and for each of these identifies organizations that violate these assumptions and theoretical opportunities attached to studying such organization. For example, while the Silicon Valley Model valorizes "sustainability of returns", it is not at all uncommon for entrepreneurs to create organizations that are intentionally temporary. Shepherd and Williams (2018) describe temporary ventures in the aftermath of various natural disasters, where spontaneous and compassionate venturing-perhaps most interestingly, among "victims" living in the context of the disaster-was a source of community resilience. Comparing temporary spontaneous ventures to "persisting" spontaneous ventures, they found that temporary ventures, "focused exclusively on alleviating the suffering of victims", "focused on alleviating the most urgent and fundamental causes of suffering", "relied on an exhaustible resource source from the external environment", and "stepped up to fill in when established organizations were unable to meet victims' needs". Studying intentionally temporary ventures carefully might provide insights, for example, into whether unbinding one's venture from the need for sustainable returns reduces barriers to entry or exit for founders whose life circumstances might otherwise deter them from venturing at all. It might also provide insights into how and why entrepreneurs may address problems and opportunities that other organizations might avoid because of lack of sustainable returns.

Other articles in the same special issue of Small Business Economics challenge other assumptions of the SVM. Herrmann (2019) challenges the taken-for-granted assumptions of capitalism as monolithic and American, instead applying a "varieties of capitalism" lens. Pahnke and Welter (2019) adopt a lens that examines whether and how the German Mittelstand is antithetical to the Silicon Valley Model and show the Mittelstand to incorporate very different assumption about development and growth, but nevertheless being growth-oriented. Lehmann, Schenkenhofer, and Wirsching (2019) do something similar in comparing two very different images of entrepreneurial success, "unicorns" and "hidden champions". Stevenson, Kuratko, and Eutsler (2019) provide a hopeful assessment of how crowdfunding may challenge what we think we know about equity funding. Hodges and Link (2019) challenge assumption about entrepreneurial innovation derived from the SVM by close attention to the model 


\section{Studying Contexts}

of innovation in the apparel industry. Together, these papers give a flavor for how one might select fruitful targets when undertaking a Critical Process Approach to entrepreneurship research.

Returning to the founders themselves, rather than whether the sorts of ventures they pursue are disparaged or ignored, in the previous section regarding silent participants we pointed toward people whose existence is admitted through control variables or through being mentioned by other informants in qualitative work. We would be remiss not to point out that in our hypothetical (but not completely fictional) example of woman scientist entrepreneurs our account of this research did not even mention race, national origin, religion, sexual orientation, gender fluidity or non-conformity or any of the combinations of demographic characteristics beyond "male versus female" that form the contours of much within-nation and cross-nation inequality. Nor did we mention the elite status of the school the scientists attended, or whether they come from a position family of wealth or poverty. The multiple dimensions of wealth, power and inequality are a rich source of clues about research that can productively challenge our mainstream assumptions toward the goals of better and more useful science.

If we are looking to uncover and challenge assumptions that have become taken-for-granted while largely supporting the power and privilege status quo, we could find a worse place to look than the demographic markers of inequality. In Newark, N.J., a U.S. city with a population that is about half African-American and one-quarter white, a casual walk through an incubator or accelerator or even a co-working space will cause one to see an awful lot of white faces. If one attends Rutgers University entrepreneurship classes for previously incarcerated entrepreneurs, one will see mostly faces of color. Race matters to entrepreneurship in the U.S. But we often focus on samples of mostly white entrepreneurship and even when we do not, we seldom see a need to theorize race. In addition, some recent work beginning to discuss religion and spirituality and entrepreneurship (e.g., Audretsch, Bönte, \& Tamvada, 2007; Dana, 2010; Dodd \& Seaman, 1998; Drakopoulou Dodd \& Gotsis, 2007; Ghoul, 2015; Ojo, 2019; Smith, Conger, McMullen, \& Neubert, 2019) promises important new insights, and it will be particularly useful for this work to examine not just differences in beliefs, but also how religion affects the distribution of power, resources, status and networks that are often key to entrepreneurial success.

\section{Claiming Center Stage: The Return from Silence, Disparagement and Invisibility}

New ideas and theories do not often emerge fully fledged from some research womb. They need a chance to be incubated and to develop, as part of the conversation that takes place through publication. In general, therefore, we think it makes sense for ideas that are novel and interesting 
but that are difficult to research, to face somewhat different methodological standards for publication than ideas that are incremental enhancements to research streams with established methodological approaches. It is our experience that good journals and editors sometimes act on this logic, though perhaps the greater the challenge to the contemporary state of the art, the less likely this becomes (Staw, 1984).

If new ideas get any traction at all, they can benefit from the emergence of even a small group of scholars working on similar things. It is again our personal experience that as new sets of ideas start to emerge and cohere, good editors are likely to choose at least some of the reviewers from among the limited set of authors who have published on a topic (as well as from opponents to the ideas, of course, if any have become apparent), even if the relevant papers have not been in elite journals. This may help to provide something of a nursery for the development and publication of new ideas. Even one or two publications in elite journals can seemingly open the door. We suspect that this may have happened even with some of what become the most important ideas in organization studies more broadly (resource dependence, population ecology, neo-institutional theory, etc.) over the past few decades. It may also have happened in some areas of entrepreneurship research, including work on women's entrepreneurship, on entrepreneurship in "emerging economies" and on the informal sector as discussed in earlier chapters.

One concern, of course, is that these nurturing niches become ghettoized: flourishing independently but too often ignored in the core theory development of the field (Baker \& Welter, 2017). We suspect that one way to avoid such ghettoization is to attract "mainstream" researchers into joining the subfield. This seems to have been an important part of the legitimation of entrepreneurship research as a whole, as some leading researchers from other fields such as sociology and psychology and more rarely economics, as well as people from other organization studies fields-especially strategy and organizational behaviour-were drawn to the newer field of entrepreneurship for various reasons.

For ideas newly claiming broader attention within the entrepreneurship domain, there may be some benefit to undertaking direct critiques of the assumptions of broad areas of established work, such as with early research on bricolage (Baker \& Nelson, 2005) or effectuation (Sarasvathy, 2001). Perhaps the most powerful case of this was Shane and Venkataraman's (2000) attack on most entrepreneurship research for what they described as overlapping too much with other fields and as attending too little to differences in the quality of opportunities that entrepreneurs discovered and exploited. What we suspect is unlikely to work, and to be self-defeating (Davidsson, 2013) is any approach that seeks to set up areas or-geographically bound-“schools" of research that are largely separate or parallel to what is currently mainstream. The goal of the CPA is to improve the quality of the science and broaden its usefulness 


\section{Studying Contexts}

by carefully examining taken-for-granted assumptions that largely serve more powerful and privileged individuals and groups. To do this, we must engage with those assumptions, rather than ignore them. We must enter the scientific fray by attempting to publish work that challenges the mainstream in order to amend and replace what our research assumes and what it silences, disparages and makes invisible.

In addition to the formation of research ghettos, there is a lot of "oneoff" critical research in entrepreneurship. For example, as Gartner (2013, p. 6) describes the European research culture in entrepreneurship, it is more likely than North American research to exhibit "a concern for the 'other', so as to challenge the unspoken and often unrecognized 'taken-for-granted' aspects of what entrepreneurship is and what it might be". But he also goes on to note that he has found no evidence of a "community" of such scholars who cite and build upon one another's work, although this may have changed to some extent over the last few years. Again, given the conservative pressures we have described at length throughout this book, we don't believe that one-off critical pieces, however finely crafted, are very often likely to have much of an effect. This is part of the reason why we have included "P" for "process" in defining the Critical Process Approach. Although it's possible for one extraordinarily productive scholar to drive changes, we suspect that CPA-driven streams of research are likely to depend on coalitions or at least congeries of researchers. Encouraging in this regard (although always in danger of developing into just another "ghetto") are the more critical and reflexive studies in entrepreneurship (e.g., Calás, Smirchich, \& Bourne, 2009; Essers, Dey, Tedmanson, \& Verduyn, 2017; Tedmanson, Verduyn, Essers, \& Gartner, 2012) that have developed over the past decade, or the recently emerging "Entrepreneurship as Practice" group, which attempts to build better theory and better interventions for practitioners by studying entrepreneurial practices (www. entrepreneurshipaspractice.com. For some of their discussions see, e.g., Champenois, Lefebvre, \& Ronteau, 2019; Johannisson, 2011; Sklaveniti \& Steyaert, 2019). We also guess that those most likely to be drawn to such emergent scholarly communities will include established researchers no longer fettered by the search for additional career rewards and earlierstage scholars both committed to social justice and trying to find a way to distinguish themselves through championing new ideas. We hope that some of the ideas we describe here may be useful for this work.

\section{A Brief Interlude: On Collaboration and the CPA}

On the topic of "researchers doing context" and how this affects methodological strategies, we want to step away for a moment from the imagery of the lone researcher trying to turn the tide in favor of some CPA perspective. Here, we briefly describe three lenses on the usefulness of collaboration. 


\section{Collaborate with Local Researchers}

Here we will describe at length some useful ways that entrepreneurship researchers try to overcome the "foreignness" of some contexts in which they seek to do research by engaging closely with those they study. One approach, which can complement engagement with those we study or even replace it if we simply can't "be there" enough, is to collaborate with local researchers. There are any number of challenges to this, ranging from the need to "trust" someone else's rendering of a context one hasn't fully experienced to potential differences in training and publication aspirations. In addition, "locals" can sometimes "share" local assumptions that might better be examined critically. But more important than these concerns, locals will usually have much deeper and truer understanding of the context of those entrepreneurs or ventures or contexts one wants to study than one can readily gain as an "outsider" and local research partners can help one make better sense of what's going on even when one engages with people one is studying.

This has been true in our own work. For example, one of us has a series of ongoing projects in South Africa. One project, resulting in a study of what makes cross-sector partnerships work in the face of deep, historically entrenched conflicting material interests, would have been impossible without partnership with scholars living and working in South Africa (Powell, Hamann, Bitzer, \& Baker, 2018). Other ongoing projects involving entrepreneurship in the informal settlements around Cape Town would be largely unthinkable without the fieldwork and intellectual engagement of several mature and talented local graduate students. Similarly, the research the other one of us conducted on entrepreneurship in so-called transition economies would not have been possible without the longstanding collaboration with researchers from several post-socialist countries in Central and Eastern Europe and Central Asia (Welter, 2016), neither would she have been successful in collecting data for her doctoral thesis from informal businesses in West and East Nigeria, without local assistance, sometimes from customers of those she set out to interview but who did not speak sufficient English. In a project on women's entrepreneurship in Moldova, Ukraine and Uzbekistan, the German team trained the Uzbek Women Business Association in basic survey and qualitative interview techniques, while they got immersed in Uzbek culture; in other projects the colleagues from Russia and Ukraine challenged our understanding of concepts such as profit, management and entrepreneurship.

In addition to being useful as a way of more quickly coming to understand something about the context in which one is working (whether this be a different geography or different along any other contextual dimension), collaborating with people for whom the context is "local" (for non-geographical examples, if one were studying the super-rich or the super-poor and one were neither of these things, a researcher at home 


\section{Studying Contexts}

with such people could be useful; if one were to study entrepreneurship in some non-mainstream religious culture, one might benefit from working with a researcher from that culture, etc.), can be an important engine of cross-case comparison. Much of the time, insights into context will come from studying "the same thing" across different contexts, allowing one to see and attempt to explain how and why they are not really quite "the same thing". A research team that includes "local" researchers in multiple contexts is likely to make quicker and more efficient progress.

\section{Collaborate with People from Different Disciplines}

The authors of this book are entrepreneurship researchers trained in different disciplinary traditions (sociology and economics). Our personal experience is that this has allowed us to clash (usually nicely) over different ways of looking at things on the way to coming to what seems a useful working relationship. There are still a lot of sociologists who look askance at what they see as the presumptions of economists (and their politics) and as many economists who see sociologists (and their politics) as fuzzy-thinking relics of the past. Sociologists and psychologists have distinctly different ways of looking at some things as do political scientists and historians and so forth. Cross-disciplinary collaborations can be challenging, not least because they violate the professional silos around which universities are structured. The good news, however, is that such work is possible among reasonable people, as reflected in one of our recent endeavors (Welter et al., 2017). Two economists, a sociologist and a scholar trained in business administration discovered a common interest and concern: all four of us were dissatisfied with the narrow way our discipline comprehends the rich varieties of entrepreneurship we observe around us and especially the limited forms of entrepreneurship that we mostly talk about. We set out to write an essay pushing for new conversations in entrepreneurship, but to our surprise, the process began with an intense debate on how we should label what we were to write about: Main Street entrepreneurship (David), ordinary entrepreneurship (Bill), mundane entrepreneurship (Friederike) or normal entrepreneurship (Ted) (Welter, 2019, p. XXI). Neither of us can recall how we finally arrived at "everyday entrepreneurship" - but our discussion illustrates how important such conversations are. Such a clash of dearly held assumptions may light the way for constructing effective challenges to some of those whose time has come to depart center stage.

\section{Collaborate with Those We are Studying}

If we are to take seriously the notion that we shouldn't just assume that the rules and meanings and patterns and choices that shape entrepreneurship for people different than those we've already studied and in different contexts, are the same as what we already know, then we should consider 
the various ways we can interact with those we are studying to learn from what they know. Our emphasis is first on various forms of ethnography, engaged research, and "small n" cross-case comparison that rely on so-called "emic" approaches that attempt to comprehend and make theoretical sense of the life-worlds (Schutz, 1967)—entrepreneurship as it is lived day-to-day-of those we study. We describe some of these here.

Phenomenological approaches allow rich insights into the lived experiences of individuals, showing how they "experience and enact certain phenomena or situations" (Berglund, 2015, p. 480). Contrary to cognitive and discursive methodological approaches that may run the risk of downplaying the ambiguity and uncertainty of real-life entrepreneurship, phenomenological approaches allow us to capture the complex interactions between entrepreneurs and their multiple contexts. For example, Pret and Carter (2017) used an interpretative phenomenological approach in investigating the lived experiences of $10 \mathrm{craft}$ entrepreneurs that supported community and social growth and showing why industry and community embeddedness can result in entrepreneurs feeling responsible for collaborating and sharing resources with competitors. Also, Powell and Baker (2014) drew implicitly on phenomenological approaches as they dug into the lived experiences of textile and apparel entrepreneurs who enacted very similar objective situations into very different circumstances around which they structured their strategic responses. Müller and Korsgaard (2018), in their study of rural entrepreneurs in Denmark, outline how entrepreneurs relate to their spatial contexts, continuously and creatively reinterpreting and recombining resources. Studying individuals who are engaged in informal cross-border activities in European borderlands, Welter, Xheneti, and Smallbone (2018) identify the patterns and outcomes of individual resourcefulness in unstable institutional contexts, showing the variations of individual interactions with their contexts, in utilizing the intangible resources found in spatial, socio-cultural and institutional contexts.

Other research has used ethnographic methods, again following the methodological insights from other disciplines but also pre-empting the recent call for more ethnography in entrepreneurship studies (see the papers from a 2017 Princeton-Kauffman Conference on expanding understanding of business creation by bringing more ethnography into the mix). One such example is Wigren (2003) who explored the famous "spirit of Gnosjö", an industrial district in Southern Sweden: she immersed herself in the workings of the industrial district and in the daily life of the community. Her results illustrate how people's interpretation may differ from their (entrepreneurial) behavior, both depending on the respective contexts they are part of as well as whether they live and work inside or outside the industrial district. Similarly, McKeever, Jack, and Anderson (2015) draw on ethnomethodology, using participant observation to look at the role of entrepreneurship in changing communities. The authors explored the situated practices of entrepreneurs 


\section{Studying Contexts}

in two depleted communities in Northwest Ireland, illustrating the high level of contextual awareness of entrepreneurs, where entrepreneurs not only used resources available in the community for their business but also gave back to their places by being involved in a wide range of community activities. Chalmers and Shaw (2017) suggest to combining ethnomethodology, conversation analysis and insights from the "practice turn" in organization studies, as a form of context-sensitive methodology. Their emphasis lies on the interpretation, and inherent in this the individually different understanding and construction of contexts. The authors make a strong case for researchers to be aware of whose understanding of contexts they analyze-their own or that of the entrepreneurs?

\section{From Concrete Individuals to Abstract Groupings}

One of the real potential quagmires of attending to context can be envisioned by asking the rhetorical question: "Can we every really understand another person"? The answer to this question is clearly "no". Or maybe it is "yes". In some fields, perhaps especially anthropology (as well as fields in the humanities), commitment to respect for other cultures and for how people in those cultures organize and create meaning in their lives—sometimes called "cultural relativism" (Boas, 1887)—suggests that the only way for an "outsider" to properly understand any part of social life in another culture is to embed oneself in it on its own terms (Scharfstein, 1989). During the early twentieth century, this led to a focus on the creation of any number of well-known ethnographies attempting to adopt this approach (Malinowski, 1922; Mead, 1928). As described earlier, some work animated by similar concerns has found its way into the entrepreneurship literature in recent years.

As Baker and Welter (2018, p. 366) discuss at some length, when focusing on taking seriously the perspectives of those being studied, doing context may begin "with the optimistic and critical desire to take into consideration differences in shared circumstances that characterize different groups of people and to understand and respect cultural, subcultural, racialized, gendered, religiously-based and other differences" but if taken to extremes "one scholarly epistemological dead end of extreme contextualization is solipsism, the radically individualized perspective in which there is no apparent way for anyone-researchers included-to know or to understand anyone or anything but themselves". Without going this far, the argument still provides a perspective in which the individual can be seen as the logical endpoint of contextualization. One way of thinking about the need for contextualization is to consider what we label, using folk terminology, the individual's "circumstances". By this we mean the elements of context, taken from the perspective of the individual actor, including their adaptation and resistance to the environments they have experienced and in which they are currently embedded. From this angle, 
the individual becomes the nexus of all dimensions of context in a way that is sensitized to the possibilities and limitations of personal agency. We thus envision an extreme version of "intersectionality", in which the CPA heuristic is to ask three questions: what are the constraints and affordances the environment provides for this person? How do they do context within the environment? Does our research serve this individual?

Constraints and affordances is largely an "objective" question, including things like the institutional environment laid out by economists such as Douglass North, the political environment, overall levels of wealth, the degree of socioeconomic, racial and gender inequality, the degree of intra and inter-generation socioeconomic mobility, the prevalence of violence, of religious tolerance, etc. The world is a very heterogeneous place across these and other dimensions. They all shape the environment of constraints and affordances for entrepreneurship. Again, we cannot attend simultaneously to all dimensions and facets of context. The challenge is to focus on examining context in ways that challenges assumptions of mainstream research that serves primarily those who are already privileged. Unless CPA-driven research stays focused on this goal, it is too easy to get lost in the weeds of the infinite individual differences shaped by the intersectional complexities of context and the courses of lives lived through them.

In our view, a core question is "how do entrepreneurs do context?", given the environments in which they are embedded. Challenging-and important to the CPA goals of better and more broadly useful scienceare attempts to understand differences in how founders in very similar environments differ in their behavior. This is, for example, one way to think about Pahnke and Welter's (2019) comparison of Silicon Valley and the Mittelstand. What is interesting in the first place about the Silicon Valley to Mittelstand comparison is not so much the environment-two advanced industrial economies with many similarities (though we don't seek to trivialize the differences)-but rather the differences in how entrepreneurs respond to these environments and do context. German and U.S.-based entrepreneurs in this study respond to similar constraints and affordances with very different patterns of entrepreneurship. If we can't readily understand even why and how this happens, our theories must be sorely lacking, because most of this important activity takes place around the privileged core that our research has come to serve. What seems most keenly interesting in their paper is that explaining the distinctly different patterns of entrepreneurship between the SVM and the Mittelstand Model requires understanding not just the contemporaneous circumstances of the founders, but the history of the environment and the individuals' embeddedness within it. This reinforces that explaining differences in how entrepreneurs do context requires more attention to historical contexts in which they work than is typical of most of our research. Such studies also suggest that, despite out long history of focus 
on such things, we still have something to learn by comparing privileged actors across different relatively munificent environments.

It's fun to take any other place and compare it to the environment for doing entrepreneurship in Silicon Valley. But, of course, doing this comes at the risk of continuing to enshrine the SVM as somehow the "standard" and treating everything else as less important or interesting "other" entrepreneurship. A very different but useful heuristic is to seek out founders who face seeming disadvantage in terms of the environments in which they are embedded-whether those environments are munificent or not, more generally-and to study the different ways in which they enact the contexts of their work. Such studies help to sketch out the possibilities, mechanisms and limitations of entrepreneurial agency. By causing us to observe differences in outcomes from different ways of doing context in very similar environments, they can also point us toward useful insights about what works under what conditions, helping to guide us toward making our research useful to those now silenced, disparaged as uninteresting or rendered invisible.

We need systematic comparison of patterns of entrepreneurship across different environments that are all unlike the SVM of entrepreneurship. One way in which this has happened is in work that describes its context as "emerging economies". Not too long ago, "more" versus "lesser developed" was in common use but is now considered inappropriate. Some authors continue to use "advanced industrial economies" to distinguish what used to be "more developed". Others use "Global North" versus "Global South", which puts Australia and New Zealand in an awkward position if taken literally and generates other complaints as well. We think this terminological trouble points not only to evolving political sensitivities, but also to the need to dismantle "emerging economies" or the "Global South" or whatever one might want to call them in our work on entrepreneurship. One may very well believe that many emerging economies are similar because they have similar histories of difficult placement in some world system and that it therefore makes sense to treat them as of a piece for many analyses. But to us, for entrepreneurship research, this sounds too much like glomming them all together as the same, which is easy to do if we focus on the roughly shared ways that they are all different from the SVM. And it's hard to believe that "shacktowns" (again, our apologies to anyone who may find this term offensive) in Latin America, Africa and elsewhere don't share many similarities. But it's useful for a CPA to examine both the similarities and the differences among systematically less privileged entrepreneurs and the contexts in which they operate.

Despite our deepened sensitivities, it is perhaps not too much of an exaggeration to compare this to the old days of cultural anthropology, when all "primitive" societies where classified together in terms of their position relative to more advanced societies (i.e., those where the anthropologists lived). It was only through close examination of the variations within and 
among the "primitive" societies that anthropologists were able to see the rich variety of ways that societies (in our terms) did context, or to see that there was little basis for the whole racist scholarly rigamarole of ladders of ascent from primitive to "civilized" peoples and cultures (King, 2019).

\section{Small-N Versus Large-N Research in CPA-Driven Approaches}

Still maintaining our focus on the circumstances of individual founders as the nexus of contextual elements from the founder's perspective, we believe that CPA researchers should attempt to the extent possible to understand context from the perspective of the founders themselves. There are a number of ways to do this. Perhaps the gold standard is through ethnography, where the researcher goes and lives among those who are being studied for an extended period of time, trying to understand them on their own terms before switching from an emic to an etic perspective in bringing theory to bear. Unfortunately, this is badly out of synch with the temporal rhythms and requirements of most contemporary academic social science careers, perhaps especially in business schools. Another way of trying to get to know people on their own terms is through so-called "engaged research" in which the researcher participates as part of some intervention that may allow them to gain causal insights through seeing processes of change that occur in response to the interventions (Zahra \& Wright, 2011). Unfortunately, it seems to be the case that much engaged research has a difficult time making its way into our more selective journals, presumably in part because the interventions often seem-usually unavoidably-like inadequately structured experiments (Campbell \& Cook, 1979) and perhaps also because the researchers can make few claims to scientific "disinterest".

Most qualitative research in entrepreneurship seems to take the form of generating theory through cross-case comparative approaches (Baker et al., 2017; Eisenhardt, 1989; Perren \& Ram, 2004; Yin, 2009). Such work can range from collecting data primarily through semi-structured interviews (Gioia, Corley, \& Hamilton, 2013) with key informants to combinations of interviews, observation, participant observation and interviews with multiple participants, neighbors and employees. To our knowledge, most of the research in entrepreneurship on different responses to penurious and otherwise challenging environments have been "small-n", and mainly qualitative studies (Baker et al., 2017) focused in specific geographic areas. But there is no reason why this needs to be the case. Moving beyond the individual circumstances on which we have been focusing, comparative field work that identifies key constructs and relationship could easily lead to quantitative theory-testing studies using data from structured interviews or even self-completed questionnaires across multiple locations. As we argued, none of our research can ever fully understand the circumstances of any individual in their unique 


\section{Studying Contexts}

perspective. Every time we are theorizing, we are talking about abstract groupings of units: even in single-case or small-n comparative case study research, each case is in effect standing in for one or more abstract (and intersecting) categories that are assumed to contain more "like it" in the broader population. While there may be arguments about degrees of generalizability and theoretical versus empirical generalizability, almost no one is arguing that they are examining cases that are best understood as unique. Thus, the degree to which our research engages with the "emic" or is "empathetic" to those we study or gives authentic "voice" to them is always limited and a matter of degree. Knee-jerk criticism that standardized instruments and abstract characterizations that group people together in statistical models based on these characteristics must violate the intersectional uniqueness of individuals seem uncompelling to us.

For example, informal marketplaces such as La Salada outside of Buenos Aires, Argentina (Dorado \& Fernández, 2019), or Gariunai in Lithuania (Aidis, 2003) are practically important ventures for resource-constrained entrepreneurs; these exist in many parts of the world (Mörtenböck \& Mooshammer, 2015). We need much more fieldwork on these marketplaces. We also suspect that quantitative, theory testing research examining the similarities and differences in how such marketplaces shape and are shaped by the patterns of entrepreneurship that surround them may eventually turn out to be very fruitful. Such research might tell us a great deal about how local entrepreneurs do context and with what outcomes, challenging and expanding our current theories of entrepreneurial resourcefulness and perhaps providing some practical insights for people we usually ignore or disparage as unimportant and uninteresting.

A body of work that gets into the rut of only doing small-n studies risks not being able to see the forest for the trees, just as reliance on large-n studies relies on not being able to see the trees-or more specifically the diversity of the plant life-for the forest. This tension, of course, brings us back squarely to tradeoffs between the simple, the accurate and the general. To become robust or influential, CPA-driven streams of research need to engage in the respectful, cumulative scientific interplay between small and large-n studies and between the gathering and analysis of qualitative and quantitative data. The balance between simple, accurate and general at any given time does not seem to matter much: what is important for progress is that new waves of research challenge and disrupt whatever has become stale and taken for granted, especially if it serves as an ideological buttress for inequality.

For researchers attempting large-n studies, our discussion points to a few potentially useful heuristics. One of these is to pay attention to the pattern of control variables in your own and others' work in an area. Turning control variables into core theoretical variables can be an important way to challenge what is taken for granted in a body of work (Zahra \& Wright, 2011). This seems especially likely to be true when the control 
variables statistically absorb important elements of power or resource inequality; for example, race, gender, ethnicity, age, religion, regions and other demographic characteristics. Theorizing such variables, as well as introducing new variables that smaller-n studies have pointed to as important can challenge and improve accepted understandings. More challenging, perhaps, is that many times, some characteristics may be relegated to a control variable (or ignored altogether) in large part because most empirical cases of the phenomenon are (considered to be) homogenous.

To extend our prior example: if relatively few university STEM faculty who start companies based on their discoveries are African-American females, models drawn from random samples may include too few cases to examine interesting questions about differences about the intersection of race and gender in statistical models. In general, the people who our current research seems mostly to serve are themselves in the (privileged) minority, and those we argue our research needs to serve include most people. But if we examine more privileged entrepreneurial roles, the people who are disadvantaged by broader stratification systems are likely to be much rarer. This suggests that some CPA-driven quantitative research is likely to need to rely on intentional oversampling of entrepreneurship involving less-privileged demographics and environments. This is very directly a model of mindfully working to acknowledge the presence of those whose entrepreneurship is easily ignored and giving them some voice in our work. It also paves the road towards understanding their value and through studying why they are so relatively few, the potential value that may be squandered through the circumstances in which they live and work. Such oversampling may be somewhat challenging but with rather large potential payoffs. These payoffs include driving progress toward making our theories more interesting and useful to a broader set of entrepreneurs and potential entrepreneurs.

\section{References}

Aidis, R. (2003). Officially despised yet tolerated: Open-air markets and entrepreneurship in post-socialist countries. Post-Communist Economies, 15(3), 461-473.

Aldrich, H. (1992). Methods in our madness? Trends in entrepreneurship research. In D. L. Sexton \& J. D. Kasarda (Eds.), The state of the art of entrepreneurship (pp. 191-213). Boston, MA: PWS-Kent.

Aldrich, H., \& Baker, T. (1997). Blinded by the cites? Has there been progress in entrepreneurship research? In D. L. Sexton \& R. W. Smilor (Eds.), Entrepreneurship 2000 (pp. 377-400). Chicago, IL: Upstart Publishing.

Aldrich, H., \& Ruef, M. (2018). Unicorns, gazelles, and other distractions on the way to understanding real entrepreneurship in America. Academy of Management Perspectives, 32(4), 458-472.

Alvesson, M., \& Kärreman, D. (2000). Taking the linguistic turn in organizational research: Challenges, responses, consequences. The Journal of Applied Behavioral Science, 36(2), 136-158. 


\section{Studying Contexts}

Audretsch, D. B., Bönte, W., \& Tamvada, J. P. (2007). Religion and entrepreneurship. Jena Economic Research Paper, No 2007-075. Jena: Max Planck Institute, Jena.

Baker, T. (2007). Resources in play: Bricolage in the toy store(y). Journal of Business Venturing, 22(5), 694-711.

Baker, T., \& Nelson, R. E. (2005). Creating something from nothing: Resource construction through entrepreneurial bricolage. Administrative Science Quarterly, 50(3), 329-366.

Baker, T., \& Powell, E. E. (2019). Entrepreneurship as a new liberal art. Small Business Economics, 52(2), 405-418.

Baker, T., Powell, E. E., \& Fultz, A. E. (2017). Whatddya know? Qualitative methods in entrepreneurship. In R. Mir \& S. Jain (Eds.), The Routledge companion to qualitative research in organization studies (pp. 248-262). New York, NY; Abingdon: Routledge.

Baker, T., \& Welter, F. (2017). Come on out of the ghetto, please: Building the future of entrepreneurship research. International Journal of Entrepreneurial Behaviour \& Research, 23(2), 170-184.

Baker, T., \& Welter, F. (2018). Contextual entrepreneurship: An interdisciplinary perspective. Foundations and Trends in Entrepreneurship, 14(4), 357-426.

Berglund, H. (2015). Between cognition and discourse: Phenomenology and the study of entrepreneurship. International Journal of Entrepreneurial Behavior \& Research, 21(3), 472-488.

Boas, F. (1887). Museums of ethnology and their classification. Science, 9, 587-589.

Calás, M. B., Smirchich, L., \& Bourne, K. (2009). Extending the boundaries: Reframing entrepreneurship as social change through feminist perspectives. Academy of Management Review, 34(3), 552-569.

Campbell, D. T., \& Cook, T. D. (1979). Quasi-experimentation: Design \& analysis issues for field settings. Boston, MA: Houghton-Mifflin.

Chalmers, D. M., \& Shaw, E. (2017). The endogenous construction of entrepreneurial contexts: A practice-based perspective. International Small Business Journal, 35(1), 19-39.

Champenois, C., Lefebvre, V., \& Ronteau, S. (2019). Entrepreneurship as practice: Systematic literature review of a nascent field. Entrepreneurship \& Regional Development. Online early. doi:10.1080/08985626.2019.1641975

Dana, L. P. (2010). Introduction: Religion as an explanatory variable for entrepreneurship. In L. P. Dana (Ed.), Entrepreneurship and religion (pp. 1-24). Cheltenham: Edward Elgar.

Davidsson, P. (2013). Some reflection on research 'Schools' and geographies. Entrepreneurship \& Regional Development, 25(1-2), 100-110.

de Holan, P. M. (2014). It's all in your head: Why we need neuroentrepreneurship. Journal of Management Inquiry, 23(1), 93-97.

Dencker, J., Bacq, S. C., Gruber, M., \& Haas, M. (2019). Reconceptualizing necessity entrepreneurship: A contextualized framework of entrepreneurial processes under the condition of basic needs. Academy of Management Review. Online early. doi:10.5465/amr.2017.0471

Dodd, S. D., \& Seaman, P. T. (1998). Religion and enterprise: An introductory exploration. Entrepreneurship Theory and Practice, 23(1), 71-86. 
Dorado, S., \& Fernández, P. D. (2019). An institutional framework to the scaling up of inclusive social innovations: The case of La Salada. In G. George, T. Baker, P. Tracey, \& H. Joshi (Eds.), Handbook of inclusive innovation (pp. 266-283). Northampton, MA: Edward Elgar.

Drakopoulou Dodd, S., \& Gotsis, G. (2007). The interrelationships between entrepreneurship and religion. The International Journal of Entrepreneurship and Innovation, 8, 93-104.

Eisenhardt, K. M. (1989). Building theories from case-study research. Academy of Management Review, 14(4), 532-550.

Essers, C., Dey, P., Tedmanson, D., \& Verduyn, K. (2017). Critical entrepreneurship studies: A manifesto. In C. Essers, P. Dey, D. Tedmanson, \& K. Verduyn (Eds.), Critical perspectives on entrepreneurship (pp. 1-14). London: Routledge.

Fayolle, A., Landström, H., Gartner, W. B., \& Berglund, K. (2016). The institutionalization of entrepreneurship: Questioning the status quo and re-gaining hope for entrepreneurship research. Entrepreneurship \& Regional Development, 28(7-8), 477-486.

Frank, H., \& Landström, H. (2016). What makes entrepreneurship research interesting? Reflections on strategies to overcome the rigour: Relevance gap. Entrepreneurship \& Regional Development, 28(1-2), 51-75.

Gartner, W. B. (2013). Creating a community of difference in entrepreneurship scholarship. Entrepreneurship \& Regional Development, 25(1-2), 5-15.

Ghoul, W. A. (2015). Entrepreneurship within the framework of Shari'ah. International Journal of Business and Globalisation, 15(3), 262-271.

Gioia, D. A., Corley, K. G., \& Hamilton, A. L. (2013). Seeking qualitative rigor in inductive research: Notes on the Gioia methodology. Organizational Research Methods, 16(1), 15-31.

Guillory, S., Boardman, M. C., \& Day, M. (2017). A few words about what neuroentrepreneurship can and cannot help us with. In M. Day, M. C. Boardman, \& N. F. Krueger Jr (Eds.), Handbook of research methodologies and design in neuroentrepreneurship (pp. 285-291). Cheltenham: Edward Elgar.

Herrmann, A. M. (2019). A plea for varieties of entrepreneurship. Small Business Economics, 52(2), 331-343.

Hodges, N. J., \& Link, A. N. (2019). Innovation by design. Small Business Economics, 52(2), 395-403.

Hsu, D. K., Simmons, S. A., \& Wieland, A. M. (2017). Designing entrepreneurship experiments: A review, typology, and research agenda. Organizational Research Methods, 20(3), 379-412.

Johannisson, B. (2011). Towards a practice theory of entrepreneuring. Small Business Economics, 36(2), 135-150.

King, C. (2019). Gods of the upper air. New York, NY: Random House.

Kraus, S., Ribeiro-Soriano, D., \& Schüssler, M. (2018). Fuzzy-set qualitative comparative analysis (fsQCA) in entrepreneurship and innovation research: The rise of a method. International Entrepreneurship and Management Journal, 14(1), 15-33.

Lehmann, E. E., Schenkenhofer, J., \& Wirsching, K. (2019). Hidden champions and unicorns: a question of the context of human capital investment. Small Business Economics, 52(2), 359-374. 


\section{Studying Contexts}

Malinowski, B. (1922). Argonauts of the Western Pacific: An account of native enterprise and adventure in the archipelagoes of Melanesian New Guinea. London: Routledge.

McKeever, E., Jack, S., \& Anderson, A. (2015). Embedded entrepreneurship in the creative re-construction of place. Journal of Business Venturing, 30(1), 50-65.

Mead, M. (1928). Coming of age in Samoa: A psychological study of primitive youth for western civilization. New York, NY: William Morrow \& Company.

Mörtenböck, P., \& Mooshammer, H. (2015). Informal market worlds: The architecture of economic pressure-ATLAS. Rotterdam: nai010 publishers.

Müller, S., \& Korsgaard, S. (2018). Resources and bridging: The role of spatial context in rural entrepreneurship. Entrepreneurship \& Regional Development, 30(1-2), 224-255.

Neergaard, H., \& Leitch, C. M. (Eds.). (2015). Handbook of qualitative research techniques and analysis in entrepreneurship. Cheltenham: Edward Elgar.

Nicolaou, N., \& Shane, S. (2014). Biology, neuroscience, and entrepreneurship. Journal of Management Inquiry, 23(1), 98-100.

Ojo, S. (2019). The confluence of religion and ethnic entrepreneurship in the informal economy. In V. Ramadani, L. P. Dana, V. Ratten, \& A. Bexheti (Eds.), Informal ethnic entrepreneurship (pp. 45-62). Cham: Springer.

Pahnke, A., \& Welter, F. (2019). The German Mittelstand: Antithesis to Silicon Valley entrepreneurship? Small Business Economics, 52(2), 345-358.

Perren, L., \& Ram, M. (2004). Case-study method in small business and entrepreneurial research: Mapping boundaries and perspectives. International Small Business Journal, 22(1), 83-101.

Powell, E. E., \& Baker, T. (2014). It's what you make of it: Founder identity and enacting strategic responses to adversity. Academy of Management Journal, 57(5), 1406-1433.

Powell, E. E., Hamann, R., Bitzer, V., \& Baker, T. (2018). Bringing the elephant into the room? Enacting conflict in collective prosocial organizing. Journal of Business Venturing, 33(5), 623-642.

Preston, L. M. (1995). Theorizing difference: Voices from the margins. American Political Science Review, 89(4), 941-953.

Pret, T., \& Carter, S. (2017). The importance of fitting in: Collaboration and social value creation in response to community norms and expectations. Entrepreneurship \& Regional Development, 29(7-8), 639-667.

Rosa, P., Kodithuwakku, S., \& Balunywa, W. (2006). "Entrepreneurial motivation in developing countries: What does "necessity" and "opportunity" entrepreneurship really mean?" Paper presented at the Babson-Kauffman Entrepreneurship Research Conference (BKERC).

Sarasvathy, S. D. (2001). Causation and effectuation: Toward a theoretical shift from economic inevitability to entrepreneurial contingency. Academy of Management Review, 26(2), 243-263.

Scharfstein, B. A. (1989). The dilemma of context. New York, NY: New York University Press.

Schjoedt, L., \& Bird, B. (2014). Control variables: Use, misuse and recommended use. In A. L. Carsrud \& M. Brännback (Eds.), Handbook of research methods and applications in entrepreneurship and small business (pp. 136-155). Cheltenham: Edward Elgar. 
Schutz, A. (1967). The phenomenology of the social world. Chicago, IL: Northwestern University Press.

Shane, S., \& Venkataraman, S. (2000). The promise of entrepreneurship as a field of research. Academy of Management Review, 25(1), 217-226.

Shepherd, D. A., \& Williams, T. A. (2018). Spontaneous venturing: An entrepreneurial approach to alleviating suffering in the aftermath of a disaster. Cambridge, MA: Massachusetts Institute of Technology Press.

Sklaveniti, C., \& Steyaert, C. (2019). Reflecting with Pierre Bourdieu: Towards a reflexive outlook for practice-based studies of entrepreneurship. Entrepreneurship \& Regional Development. Online early. doi:10.1080/08985626.2019.16 41976

Smallbone, D., \& Welter, F. (2003). "Entrepreneurship in transition economies: Necessity or opportunity driven?" Paper presented at the Babson-Kauffman Entrepreneurship Research Conference (BKERC), Babson College.

Smith, B. R., Conger, M. J., McMullen, J. S., \& Neubert, M. J. (2019). Why believe? The promise of research on the role of religion in entrepreneurial action. Journal of Business Venturing Insights, 11, e00119.

Smith, R., \& Anderson, A. R. (2007). Daring to be different: A dialogue on the problems of getting qualitative research published. In H. Neergaard \& J. P. Ulhøi (Eds.), Handbook of qualitative research methods in entrepreneurship (pp. 434-459). Cheltenham: Edward Elgar.

Staw, B. M. (1984). Repairs on the road to rigor and relevance: Some unexplored issues in publishing organizational research. In L. L. Cummings \& P. J. Frost (Eds.), Publishing in the organizational sciences (pp. 85-97). Thousand Oaks, CA: Sage.

Stevenson, R. M., Kuratko, D. F., \& Eutsler, J. (2019). Unleashing main street entrepreneurship: Crowdfunding, venture capital, and the democratization of new venture investments. Small Business Economics, 52(2), 375-393.

Tedmanson, D., Verduyn, K., Essers, C., \& Gartner, W. B. (2012). Critical perspectives in entrepreneurship research. Organization, 19(5), 531-541.

Treffers, T. (2017). A few words about neuroexperimental designs for the study of emotions and cognitions in entrepreneurship. In M. Day, M. C. Boardman, \& N. F. Krueger (Eds.), Handbook of research methodologies and design in neuroentrepreneurship (pp. 246-258). Cheltenham: Edward Elgar.

Welter, F. (2016). Wandering between contexts. In D. Audretsch \& E. Lehmann (Eds.), The Routledge companion to makers of modern entrepreneurship (pp. 213-232). London: Routledge.

Welter, F. (2019). Introduction. In F. Welter (Ed.), Entrepreneurship and context (pp. IX-XXXI). Cheltenham: Edward Elgar.

Welter, F., Baker, T., Audretsch, D. B., \& Gartner, W. B. (2017). Everyday entrepreneurship: A call for entrepreneurship research to embrace entrepreneurial diversity. Entrepreneurship Theory and Practice, 41(3), 311-321.

Welter, F., Baker, T., \& Wirsching, K. (2019). Three waves and counting: The rising tide of contextualization in entrepreneurship research. Small Business Economics, 52(2), 319-330.

Welter, F., \& Lasch, F. (2008). Entrepreneurship research in Europe: Taking stock and looking forward. Entrepreneurship Theory and Practice, 32(2), 241-248. 


\section{Studying Contexts}

Welter, F., Xheneti, M., \& Smallbone, D. (2018). Entrepreneurial resourcefulness in unstable institutional contexts: The example of European Union borderlands. Strategic Entrepreneurship Journal, 12(1), 23-53.

Wigren, C. (2003). The spirit of gnosjö: The grand narrative and beyond. Jönköping: Internationella Handelshögskolan.

Williams, N., \& Williams, C. C. (2014). Beyond necessity versus opportunity entrepreneurship: Some lessons from English deprived urban neighbourhoods. International Entrepreneurship and Management Journal, 10(1), 23-40.

Yin, R. K. (2009). Case study research: Design and methods. Thousand Oaks: Sage.

Zahra, S. A., \& Wright, M. (2011). Entrepreneurship's next act. Academy of Management Perspectives, 25(4), 67-83.

\section{Websites}

Retrieved 1 September 2019, from www.entrepreneurshipaspractice.com Retrieved 3 September 2019, from www.princetonkauffman2017.com/ 


\section{Narrating and Visualizing Contexts}

There are many research approaches that can be put to good use in researching contexts empirically while applying a critical lens. Unfortunately, our "research methods seem to have become a context in itself, irrespective of whether those methods are the best fit with our research questions", and irrespective of whether they are context-sensitive (Brännback \& Carsrud, 2016, p. 21). In contrast, doing context critically implies a different way of researchers seeing and understanding the world and therefore often requires being bold and entrepreneurial when choosing how to go about one's work. Other fields have had long, often richly insightful debates as to which research approaches and methods can best drive contextualization (see our review in Baker \& Welter, 2018). Communication and media research, socio-linguistics, information science and human-computer interaction studies have turned to ethnomethodology, conversation analysis and other interpretative and narrative methods (e.g., Bazzanella, 2002; Labov, 1970; McHoul, 2008), which encourage researchers to simultaneously look at talk, action and interaction as well as embodiment and artifacts within and across contexts, while being respectfully observant about how individuals and groups construct the contexts in which they operate. An important theme running through studies across many disciplines points to the active construction of contexts through language and through non-verbal interactions. For example, de Kok (2008) shows how a cultural context is not only "out there", but also continuously constructed by those who are part of the culture, even, tellingly, during the moments in which people react to her as a researcher who is an outsider to the country and its culture. Other studies use approaches that point to the processes that structure contexts (Broth, 2008; Broth \& Mondada, 2013; McHoul, Rapley, \& Antaki, 2008), emphasizing the role and importance of non-verbal language, interactions, movements and artifacts (Dourish, 2004; Dupret \& Ferrié, 2008). Some suggest how doing context supports a mandate to not only analyze but also visualize context (Bar, 2004). Inspired by such approaches, in this chapter, we want to focus on some research approaches that promote 
the study of how contexts are constructed both verbally and visually and how researchers can do context in exploring such constructions.

\section{The Stories We Tell and Listen To: Linguistic Themes in Entrepreneurship Research}

Language creates contexts for entrepreneurship, and it contributes to changing them. Contextualizing through language emerges as a neverending loop, where speech and actions are shaped by contexts and simultaneously renew them (Akman, 2000), thus allowing us to consider contexts as both shaping and being shaped by entrepreneurs and their behavior. In all its facets and varieties, language is a crucial element that shapes, influences and constructs contexts and to which we need to attend in exploring and explaining differences in entrepreneurship. For most of us trained as entrepreneurship researchers and with little exposure to the tools of linguistics, a major challenge is how we might explore not only the hidden (to us) but crucial and informative aspects of narratives and stories as well as the manifold other ways language matters. The increasing focus of the entrepreneurship field on linguistics methods is particularly suited to assisting us in re-storying entrepreneurship in line with the CPA we put forward in Part II of this book.

\section{Linguistic Methods for Doing Context as Researchers}

Better-known linguistic methods in entrepreneurship include discourse or narrative analysis and, more recently, corpus-linguistic techniques. Research drawing on these approaches highlights the ways that contexts are part of the story. Often, when incorporating linguistic methods into entrepreneurship research, we continue to do context in ways that mostly corroborate and complement our more usual methods. Over time, however, linguistic methods have also allowed some researchers to explore more critical perspectives. Linguistic approaches can provide a close look at the role of language in legitimizing (entrepreneurial) actions and behavior within contexts and thereby perhaps more broadly illuminate the construction of contexts in which entrepreneurs operate. Individuals construct, re-construct and enact their storylines and narratives in part through their engagement with discourses (Berglund, 2015, p. 476) which shape the processes through which entrepreneurial actions and events become meaningful (Berglund, 2007, p. 87). This applies to entrepreneurs and researchers alike.

A growing body of entrepreneurship studies draws on linguistics in ways that can challenge what we otherwise take for granted. As we touched upon in Part II of this book, such research studies the use of language, words, rhetoric styles or patterns of speech in various texts and situations to gain insights into entrepreneurs doing contexts and-albeit 
sometimes more implicitly—-to advance a more critical approach towards what constitutes entrepreneurship, its heterogeneity and its everydayness.

Some authors apply discourse analysis to identify overarching debates and discussions around entrepreneurship that would not be visible or recognizable were entrepreneurship viewed solely as an individual phenomenon. For example, Cohen and Musson (2000) explored how individuals working in a small business were influenced by and reproduced the overarching public enterprise discourse. Others have applied discourse analysis to examine texts on women's entrepreneurship (Ahl, 2002), media discourses around women entrepreneurs (e.g., Achtenhagen \& Welter, 2007; Achtenhagen \& Welter, 2011; Baker, Aldrich, \& Liou, 1997; Eikhof, Summers, \& Carter, 2013; Ljunggren \& Alsos, 2001) or around entrepreneurship in general (Achtenhagen \& Welter, 2007), analyzing the imagery of entrepreneurship as portrayed by media discourses that in turn contribute to the general perception of entrepreneurship in our societies. Again, as noted in Part II of this book, some research combines discourse and linguistic analysis; for example, by analyzing the role of metaphors in creating contextualized meanings of entrepreneurship at individual, regional or country levels (for an overview of related studies, see Welter, 2019). Other studies have examined the role of language and narratives in creating or destroying entrepreneurship, promoting particular forms or fostering entrepreneurial places. For example, Parkinson, Howorth, and Southern (2017) show the influence of language on the imagery and reputation of entrepreneurship in deprived communities. Roundy (2016) discusses the positive and negative effects of narratives in relation to entrepreneurial ecosystems, and Roundy (2019) extends these ideas, presenting a model of competing spatial narratives and theorizing that the creation or renewal of entrepreneurial ecosystems depends on whether new narratives are able to overcome entrenched spatial stories.

Researchers also have started to apply corpus linguistics (CL), a computer-based technique that allows detection of linguistic patterns within large corpora of texts, thus extending linguistic analysis forward from the manual content analysis of, for example, media representations of entrepreneurship (e.g., Achtenhagen \& Welter, 2003, 2004; Baker et al., 1997). CL combines computational analysis of texts with subsequent qualitative analysis, thus incorporating some of its richness of understanding. CL methods can assist in challenging common myths: for example, the use of metaphors, contradictory to what one might expect, has shown to be less frequent in news texts than in academic texts (Krennmayr, 2015). There is a still sparse but growing body of CL studies in entrepreneurship research. Parkinson and Howorth (2008) build on CL in combination with critical discourse analysis in order to identify common linguistic themes on social entrepreneurship, showing how the discourse is anchored in geographical and social contexts of communities and collective actions. Chandra (2017) applies CL to a small group of 


\section{Studying Contexts}

Chinese social entrepreneurs that offer taxi services to physically disabled people, identifying a number of meta discourses that range from the more business-related (marketization, resource mobilization) towards the more policy-related (empowerment, publicness). Perren and Dannreuther (2012), using CL, illustrate the political discourse around entrepreneurship as "floating" and constructed from the words around the term, i.e., its linguistic context. Roundy and Asllani $(2018,2019)$ rely on big data methods and text mining algorithms. They identify obvious gaps between the academic and practitioner discourses on entrepreneurship-something which had previously been done manually in entrepreneurship studies on the practice of growth talk (e.g., Achtenhagen, Naldi, \& Melin, 2010)_ as well as examining and describing the most frequently used words around entrepreneurship and the evolution of their usage.

Such researchers do not merely analyze how contexts are constructed in various ways through language use, they also do contexts themselves, in a manner consistent with our description of CPA. First, in many studies researchers apply linguistic methods to (openly) question our assumptions underlying common entrepreneurship models-we see these studies in particular as promising examples of researchers doing context in ways that help to uncover myths of entrepreneurship that shape our work. They point to how we, as researchers, contribute to sustaining those myths, keeping some voices dominant and others silent as we described in the previous chapter.

Second, researchers draw attention to public and meta-discourses and their impact on entrepreneurship, which are submerged in most work focusing on entrepreneurship at an individual level, or which treat "higher" levels of analysis as uncontested. This includes, for example, studies that analyze the media discourse around entrepreneurship and look into how places are constructed through meta-narratives, research critically reflecting on the narratives around social entrepreneurship (e.g., the chapters in Dey \& Steyaert, 2010) or research that studies the political discourses in which entrepreneurship is embedded (e.g., Dannreuther \& Perren, 2015; Perren \& Dannreuther, 2012), illustrating, for example, how official government websites may offer discourses of "domination and control" that block entrepreneurs' agency (Perren \& Jennings, 2005). It is particularly acute in work that examines struggles over the language and definitions applied to "informal sector" entrepreneurship as part of attempts to bring it under "control" (Mooshammer, 2015).

Third, when drawing on narrative and discursive approaches, we also do context through the ways in which we analyze and reflect on our results, sometimes unconsciously. In their chapter on metaphor methodologies in entrepreneurship, Drakopoulou-Dodd and De Koning (2015) recount the example from one of their own projects, a cross-national study comparing metaphor use in the newspapers of six countries (Australia, Canada, Ireland, India, the U.K., the U.S.). The authors nicely 
illustrate their degree of involvement in coding the metaphors: their best coding results were achieved for data from less familiar cultural and country contexts: Sarah (British origin) coded best on the Indian material, Alice (Canadian origin) best on the Australian data. For us their coding best for unfamiliar contexts confirms that we as researchers may sometimes do context better if we are not (too) familiar with the culture, institutions or places we study, because then we are better able to recognize that which does not "fit" our preconceived notions-thereby shedding light on outliers and interesting differences in entrepreneurship. This is not a contradiction of our earlier claim regarding the benefits of anthropological immersion or collaboration with "locals", but it does reinforce how our own circumstances change what we are able to see as new and different.

\section{From Talking to Writing About Entrepreneurship}

In the second book of the "Movements in Entrepreneurship" series, Hjorth and Steyaert (2004a, p. VIII) made the case for discursive and narrative methods as approaches that allow entrepreneurship researchers to take in "fresh air from and following new winds from neighbouring disciplines such as anthropology and literary studies (...) and their recent explorations of the linguistic turn through narrative, dramaturgical, fictive, conversational and discursive projects". The editors point out that the chapters they present in their anthology "come with embodied experiences rather than with armchair observations" (Hjorth \& Steyaert, 2004b, p. 1). The chapters use a broad variety of narrative and discursive approaches to highlight different-under-researched, silent-aspects of entrepreneurship across very different environments, illustrating how entrepreneurship is constructed and how entrepreneurs do context, and at the same time, demonstrating different facets of how researchers do context.

For example, anthropologist Lindh de Montoya (2004) vividly describes the entrepreneurial strategies of a family of taxi-owners in Caracas, the capital of Venezuela. She also discusses her involvement, pointing out that narrative approaches warrant the researchers to follow, document and listen, question and think about "what people say in a way that strives to see beyond the words, to read between the lines" (Lindh de Montoya, 2004, p. 75). The author suggests that such approaches may be academically riskier, for they immediately put the researcher into the "chaos of life, the seeming impossibility of obtaining reliable information as one succumbs to the inevitable selective memory, perspective and subjectivity" (Lindh de Montoya, 2004, p. 75) of both researchers and interviewees. But she points out that this is the reality of how businesses develop (and, we want to add, also the reality of research that relies on direct contact with people as they go about their business). Thus, narrative and discursive approaches push us towards reflecting on the suitability of 


\section{Studying Contexts}

our research approaches in general if we aim to capture the messiness of entrepreneurship and the real world of entrepreneurs, at least before we distill it into theoretical abstractions. A different writing style is visible in these studies and many others that rely on narrative approaches: abundant quotes and other ways of giving voice to those individuals or groups that researchers study are common to most of these texts.

Katz (2004) mused on the role of the researcher in the narrative process, emphasizing that we have an influence on the stories we choose to tell as well as on the ways we engage with and tell them. Through stories, we create a reality of which we are also part (Hosking \& Hjorth, 2004). We propose to take these thoughts even further, suggesting that doing context as researchers should also involve thinking critically about our own use of language in academic writing (and, as we will discuss later in this chapter, on how we use or can combine imagery in academic writing). Academic writing in our discipline follows certain rules, heuristics and templates (Shepherd \& Wiklund, 2019). Does that prevent us from trying out different ways of narrating entrepreneurship in our publications? Why are different writing styles (in our view, frequently also more engagingly written) so often to be found in conference proceedings, (edited) books, lesser-valued journals (because their impact factors are low and they are not rated as tenure-relevant by our institutions)-i.e., outlets that probably would not gain much readership? Arguably, there may be facets of language, as spoken and written words, that conventionally trained entrepreneurship researchers may consider not "scientific" enough to be persuasive, not least because they are not part of what we are trained to use, read and write, analyze and present. Some have paid attention to how the types of texts we use influences our understanding of entrepreneurship. For example, Smith (2015b) suggests poetry as (another) legitimate narrative about entrepreneurship, as poems convey both passion and power; they also apply to our auditory and visual senses (whilst academic writing often tries to restrict itself to only one sense). He further points to the fact that some of us may relate to poems, others not. We are not claiming that the language of poetry should supplant the language of social science in our work, but only that there perhaps is room for a lot more useful variation and intentional craft in how we construct our papers. If mathematics is the language of science, it is not typically the language of social science and almost never the language of entrepreneurship theory. Indeed, there is no such well-defended model for communicating the results of our work: only legitimate, taken-forgranted, tired and very slowly adapting and highly constricted form of legitimacy-seeking discourse. We believe our field would benefit from giving people the chance to be more creative in getting their ideas across.

But back to the somewhat extreme case of poetry. Bill Gartner is known for using haikus-Japanese 17-syllable poems-to illustrate his thoughts, which forces him to be short, succinct and to the point (contrary to our 
sometimes long-winded discussion sections—or, you might be thinking, parts of this book!). Examples can be found in one of the "Movements in Entrepreneurship" books (Hjorth \& Steyaert, 2010), in Welter and Gartner (2016) or in Gartner (2015), which was published in a management journal. Another memorable example of writing in a different style is his "Entrepreneurship-hop". One of us, co-editing a Special Issue of Entrepreneurship Theory and Practice on "Entrepreneurship Research in Europe" (Welter \& Lasch, 2008), asked Bill to provide some concluding thoughts, which he submitted in hip-hop form (Gartner, 2008). He also presented this as keynote at the ICSB World Conference in Turku, 2007-to many frowning and non-understanding faces in the academic audience (as well as to the delight of others). It also proved not that easy to adjust Bill's hip-hop to the rather strict requirements of the journal publisher-we puzzled quite a bit about the request (of how) to write an abstract for hip-hop writing; and also had to change Bill's reference style adapted to the hip-hop rhythm, to the "normal" journal style, notwithstanding that the publisher (not the journal editor Ray Bagby, though) took some persuading that this was a serious academic article. This serves as a reminder of the (formal) difficulties researchers may face when turning to (albeit, in this case, extreme) non-traditional academic writing formats in traditional academic outlets.

Still, we have identified several pieces of writing that are "daring to be different" (Smith \& Anderson, 2007a). To mention just a few: examples range from constructing serious fiction about counselling an entrepreneur that highlights the everydayness of entrepreneurship but also serves to visualize our theoretical concepts (Damgaard, Piihl, \& Klyver, 2004), to the dialogue between two researchers setting out to construct a fictional drama on opportunity identification for a conference and nearly ending up realizing their own business ideas (Fletcher \& Watson, 2007a), to letting the people within a small construction business speak for themselves to make their voices and their silences heard (Fletcher \& Watson, $2007 \mathrm{~b}$ ) and to imagining one story through many different voices, as in a special issue of the Journal of Business Venturing (Gartner, 2007), where the authors all used different approaches to narrate and critically question the "Toy Story" (Ahl, 2007; Allen, 2007; Baker, 2007; Fletcher, 2007; Hjorth, 2007; O'Connor, 2007; Steyaert, 2007). The writing style in these sort of papers sometimes seems more engaging and is sometimes outright passionate, as it manages not only to capture the voices of those interviewed by giving them "voice" but, in the case of Damgaard et al. (2004) and Fletcher and Watson (2007a)—, also nicely displays the personal style of the researchers. This is perhaps more visible to us for already knowing some of the authors. We already suggested that it is probably mostly well-established researchers who it is fair to invite to be more daring, as they have fewer worries about "getting enough hits in elite journals" for tenure and promotion. Alas, and nonetheless, even the 


\section{Studying Contexts}

more established among us tend to be stuck in and to favor and celebrate the "ways of doing research" that have brought us whatever success we have seen.

Fortunately, there are also encouraging examples of earlier career entrepreneurship researchers who decided to be "non-conformist" in their ways of writing and talking about entrepreneurship. For instance, in a book chapter about how to get qualitative research published (Smith \& Anderson, 2007a), Robert Smith, then still a doctoral student with his co-author, Alistair Anderson, talks about "being different" and working with a more impressionistic approach in writing up his results, which, however, also forced him to publish "elsewhere"-in books and lesserranked journals or those outside his own academic field, or only available in electronic forms (Smith \& Anderson, 2007a, pp. 446-452). Despite the difficulties, these and similar writings show the inventiveness, playfulness and creativity possible when researchers present their results in very many different ways-and we would like to make a call for all of us to be more daring in not only studying language, words and texts as they shape entrepreneurship, but also how we present stories and narratives. The richness that language allows us spans the full range of our work from our encounters with entrepreneurs to our encounters with editors, reviewers and readers. And unnecessary strictures on our attention to and crafting of language can impoverish all parts of our work.

\section{Between Narrating and Seeing: Semiotics and Visual Social Sciences}

\section{Semiotics in Entrepreneurship Studies}

Smith and Anderson (2007b) suggest a focus on semiotics in studying entrepreneurship. The authors describe their own journey in learning to apply semiotics to various texts and pictures, pointing to the subjectivity of the method as a challenge for researchers wanting to use it: "Semiotic analysis is a comparative, interpretative methodology that permits the subjectivication of the objective. Indeed, it demands that one be subjectively analytical" (Smith \& Anderson, 2007b, p. 185). Their semiotic model shows how we can construct meanings from signs and expressions, be they visual, print- or film/television-based or textual, thus allowing researchers to do context from both verbal and visual perspectives. Importantly, the semiotic analysis does not proceed linearly, but is characterized by simultaneously moving between the "doing" (as the authors label it, p. 188) of going through the material and the "analysis". Semiotic analysis allows entrepreneurship researchers to create, extract and communicate the meaning of what constitutes entrepreneurship, with particular emphasis on the "pictoriality of the entrepreneurial construct" (Smith \& Anderson, 2007b, p. 188). Their account of how they 
themselves applied semiotics in different studies (Table 7.5, pp. 186-187) already points out the active role of researchers in using this method. Smith and Neergaard (2015) present a fascinating example of researchers doing context when deconstructing and re-storying an entrepreneur's tale, as they progress from more traditional qualitative research approaches (documentary research, narrative analysis, interview) towards analyzing semiotics and the aesthetics of the entrepreneurial journey. However, their semiotic papers often lack the visual imagery which is instead sometimes relegated to a vivid, but nonetheless textual description of what the images contain. For example, in Smith and Anderson (2003), the authors outlined the semiotics of entrepreneurial identity, based on an analysis of 20 images of either entrepreneurs or images associated with entrepreneurship that point to the identities of successful of entrepreneurs. None of the images is to be found in the manuscript, though. They discuss the difficulties of getting such research published, pointing to how (we need to add: at that time when journals still were circulated in printed version) editors and publishers were unwilling to print and publish images and photographs, because of cost. But, we believe, the difficulties also relate to most of us being unskilled at and unfamiliar with how, why and when to incorporate images into our projects. We return to this theme later.

Smith (2015c, p. 76) suggests that the use of visual methods in entrepreneurship research could produce new insights and add new nuances to our analyses because our research tends to favor the written over other semiotic forms such as visual (or sensory). His own studies vividly demonstrate that a more visual research approach assists in making us aware of issues such as how gender, class and other distinctions influence our common perceptions of typical entrepreneurship, demonstrating how entrepreneurship is socially constructed as typical male or typical female through both texts and imagery (Smith, 2014) as well as highlighting which images we construe of entrepreneurship in general (Smith, 2015a). In Smith (2014), the author combined a semiotic analysis of novels with female heroines with a photomontage analysis on 100 images of women entrepreneurs, to identify typical representations of women entrepreneurs. Similar to working with post-it notes, he placed images on a wall, moving them around until visual themes and metaphors emerged-his description of the analysis demonstrates a vivid picture of a researcher doing context and visualizing entrepreneurship in different ways than just reading through and coding interview notes.

Smith (2015a) turns to "con'text'ualizing" the jacket covers of entrepreneurship textbooks. Methodologically, the author draws on established case analysis techniques, by starting with a stand-alone analysis of each cover, then coding and integrating his observations into themes, and writing up the results as visual research vignettes. He identified several overarching visual metaphors-ranging, for example, from biological and scientific/technological ones to craft-based metaphors, metaphors 


\section{Studying Contexts}

representing masculinity (such as the typical picture of a gentleman smoking a cigar) or surrealist ones which appear to be action related but without a clear visual meaning. Interestingly, the images do not present much evidence of the entrepreneur as hero, confirming how a visual analysis can add tension to our understanding and suggest a broader and perhaps more realistic picture of entrepreneurship. Perhaps this also reflects the underlying reality that most entrepreneurs put forth as "heroes" don't rely on textbooks and most entrepreneurs who rely on textbooks don't take a heroic route.

Similarly, Smith (2015c, p. 78) applied visual ethnography to a study of family businesses in Scotland, in order to "uncover the concept of 'lived business narratives' (as opposed to told narrative)", suggesting that family business researchers use visual ethnography (e.g., films, photos) as a means to analyze the contexts in which family businesses operate and family relations occur: "Visual ethnography (. . . captures so much more, for example, feelings, emotions and values". In this study, he draws on visual content analysis (see Bell \& Davison, 2013, p. 173) to identify additional aspects of the family business he studied, moving from a stand-alone analysis of each photograph to coding his observations, to collapsing them into categories to presenting the themes emerging from his analysis.

In their review of visual management studies, Bell and Davison (2013) claim to identify a visual turn in the management field. They categorize visual management studies based on research approaches, referring to the technologies used to collect data and the type of image-based data collected (static, moving, multimodal), and to theoretical frameworks guiding data analysis. In their introduction to a special issue on "Towards an articulation of the material and visual turn in organization studies", Boxenbaum, Jones, Meyer, and Svejenova (2018, p. 602) provide an overview of previous organizational studies on "visuality" which they understand as research that focuses on "how meaning is created, communicated and stored through visual means". They show that related research either focuses on the roles that "visuality plays methodologically and conceptually", or "as a unique mode of meaning construction and enactment".

In an earlier chapter of this book, we elaborated on research that showed how entrepreneurs do context visually, by emphasizing the interplay of the verbal and the non-verbal through words, images and actions. We briefly return to this research now, asking whether these studies also allow us a closer look at researchers doing context through visualizing. The answer is "yes, sometimes and if so, to a certain extent, but"! To illustrate our response, we present two examples of studies that position themselves differently as regards the role of researchers in analyzing multimodal data. Clarke (2011) who analyzed the visual symbols entrepreneurs employ to achieve support for their ventures, drew on visual ethnography: she shadowed the entrepreneurs in the three companies she analyzed, videoing where possible and writing field notes where camera 
use would have been too obtrusive. The author reflects a bit on her own role, but, having made herself as unobtrusive as possible, including using a small camera, she reflects less on how her "being there" might have impacted what she observed. Barberá-Tomás, Castello, de Bakker, and Zietsma (2019) present a fascinating longitudinal analysis of social entrepreneurs and their use of multi-modal (verbal and visual) interactions to promote their business. The authors draw on a wide array of data including social media posts and photos. However, neither does their manuscript present any of the visuals nor do the authors reflect on their own role, instead following established procedures for qualitative research in coding their rich verbal and visual material.

While these and similar studies make fascinating reading, as they draw on different (visual, multi-modal) techniques to collect data from entrepreneurs, we think that we have not yet realized the full potential of what can be achieved with attending seriously to the visual across the processes of entrepreneurship research. Entrepreneurs do context in part through reliance on the visual, researchers do context in part through visual means, and they can tell the story of their research in part through visuals that reflect the experience of the entrepreneurs. We seldom see these opportunities pursued, soup to nuts, in our research: to date, mostly only words-in the utterances of entrepreneurs, in the research materials and data assembled by researchers, and in the research "reports" we publish-are allowed pride of place across the span of the research process. This is particularly visible (pun intended) in the restricted ways that we present visual data. For example, most of the visual images of any sort are used "merely" as illustrations supporting texts, or they are treated as "simply" non-verbal data that can be presented and analyzed in much the same ways as verbal qualitative material. We now turn to explore some of the possibilities that originate from other social sciences.

\section{Moving Towards Photography: Visual Anthropology and Sociology}

We now turn to outlining some of the insights that can be gained from looking at anthropology and sociology, both disciplines with visual research streams and a tradition of combining pictures with their written words. These disciplines have often focused on images in their social contexts, emphasizing the social use of photographs to understand a phenomenon. This contrasts with photography as a scholarly field, or media studies, which more typically engage in the study of the images as such (Pink, 2003, p. 186). We will not participate here in the ongoing critiques or contestation about the use of images in social research but will rather focus on elaborating why we believe that our own discipline-and in particular CPA-infused research—could benefit from a turn to the visual. 
Researchers have used images in many different ways from which we can borrow. For example, we can create pictures to study contexts and entrepreneurship; we can analyze photographs others have taken (Harper, 1988); or we can use photographs to start a conversation with the communities, groups or entrepreneurs one studies. Anthropologists have had a long tradition of the first technique, i.e., using their own photography or film in their studies. A classic example is the photographic study of the Balinese by Bateson and Mead (1942), which the authors themselves describe as an experimental innovation. They wanted to capture more of the Balinese culture and society than they considered feasible through the usual methods of their field. The resulting publication presents several photographs, which are put into context through short descriptions of what can be seen in the pictures and thematic analyses. Notwithstanding their innovative approach and Margaret Mead's passionate call for moving anthropology from being a "discipline of words" towards integrating more of the visual (Mead, 1995), their study on Bali also reflects the observational approach that characterized social research methods at that time (Pink, 2003).

This is important because, if we are to use historical images-or any images taken by others-for entrepreneurship research, it is our role and responsibility to acknowledge the time and historical situations in which these images have been taken. Otherwise, we may invite critique and dismissal of works as sexist, derogatory or racist, as has frequently happened with some of the older photographic works in anthropology, based on the failure of those mounting the critiques to contextualize the "visual images and practices in their historical contexts of their production and viewing" (Pink, 2003, p. 185). In such cases, we must do context by trying to understand how the researchers "back then" did context as they tried to give voice to how the people, they studied did context. Even if we are critical of some of the beliefs or values that may have infused earlier work, we need to avoid blithely asserting a morally privileged position that perverts what can be learned from others' well-meaning efforts.

One of the visual sociologists whose work we have come to cherish and believe to be highly relevant to entrepreneurship researchers, is Douglas Harper. He has a fascinating personal narrative style, taking one along on his various journeys and explorations, showing his fascination with the medium of photography, whilst explicating the difficulties in getting access to the people he wanted to study and in making sense of what he saw in the images. In his various studies, he uses photography in different ways: documenting history, eliciting interviews and developing arguments about social change (Harper, 2003).

Photo elicitation or photo interviewing resembles more commonly used participatory methods in social sciences. Photo elicitation uses "images as a means to an end, rather than as an end in and of itself" (Harper, 2012, p. 155). Collier (1957) undertook an experiment, interviewing 
with photographs and without. He and his collaborators approached four informants. Where the interviews were accompanied by photos, the respondents were more concrete and to the point (which however, cut down on potentially interesting distractions in the responses), more emphatic and passionate about what they liked and disliked, and they also gave more specific information about their co-workers. The interviewers could also detect when interviewees were ignorant about a theme. Moreover, the pictures made informants forget about the notebooks where the researchers recorded their responses, whilst the respondent in the photoless interview was more nervous about the scribbled notes. Collier (1957) concluded that the photographs helped the interviewees to recall memories and thereby reduced potential misunderstandings.

Harper used this technique in talking to Willie, "the Zen master of junk" (Harper, 2012, p. 156). Willie owned a small shop (Harper, 1987). Harper reports that Willie saw Harper's work of crafting and recrafting a book from the words and photos and ideas he had accumulated to be reminiscent of his own work as a craftsman and "general mechanic" in a small shop embedded in a community. The book was a collaboration between Harper and Willie in many ways. In particular, Harper would document Willie's work and the context in which he did it. Willie would comment upon the photographs and explain what he was doing and thinking. Harper's narratives, the photographs of Willie and his work and Willie's own narratives are all incorporated in this compact and-to us-highly moving book and its broader narrative on the cost of changes to work, community and craft. Harper (2012, p. 159) suggests that photo elicitation interviews hold even more advantages than the sharper memorizing Collier (1957) identified: they generated "Verstehen" in the sense of a deep mutual feeling towards the other's point of view, characterized by setting aside one's own assumptions of how the world works and instead accepting the other's world as is shown by them. Researchers have also asked potential informants to take pictures themselves and then talk about them. For example, Bach (2001), an educational researcher working with girls, has invited them to photograph their worlds inside and outside of schools. She suggests that selfcreated images "thicken ways of seeing" (Bach, 2001, p. 7), allowing the girls to re-create and share their world with outsiders not familiar with their lives. Such methods give "voice" to insider perspectives, offering us new insights, as seeing "stereotypes from the inside humanizes what are otherwise one-dimensional social types" (Harper, 1988, p. 65). Besides educational, health and community researchers, sociologists, anthropologists-and reaching beyond academia, political activists and non-governmental organizations-have developed this further, drawing on the method of photovoice (see Harper, 2012 for an overview of related studies. In the U.K., there also exists a charity organisation, "Photovoice", which trains community and social organisations in applying 


\section{2}

such techniques in their work, cf. https://photovoice.org/). The aim is to engage and involve participants and interviewees in (research) projects in order to make the invisible visible and heard-thus suggesting a potential path toward dealing with our concerns about entrepreneurs who are disparaged or rendered invisible or silent.

Documenting history and developing arguments about social change characterize another one of Harper's books, about hidden and unknown aspects of the U.S. culture. Good Company: A Tramp Life (Harper, 2016) is a fascinating, very personal narrative about homelessness in the American subculture of hobos or tramps. This work resonates with descriptions in the novels of John Steinbeck or Jack Kerouac, but here they are illustrated with Harper's own photographs. In the early 1970s, Harper travelled with tramps, experiencing their world close-up. Reflecting on his experiences for the revised edition of his book (first published in 1982, third edition in 2016), he pointed out that his work allowed him to question several assumptions sociologists (and society) hold about homeless people. He also reflected on his initial naïveté and idealistic views of the group he travelled with, putting those down to his upbringing in a small Midwestern town where "most stories came out reasonably well and people by and large did what they said they were going to do" (Harper, 2016, p. 157). This simultaneously illustrates something about how researchers doing context, by immersing themselves into a group and its culture, can "grow", becoming more self-reflective and critically reflective of takenfor-granted assumptions and ways of doing context.

In Harper (2003), the author discusses the "virtues, difficulties and limitations of photographic ethnography" (p. 241), using his study on the changes in farming and rural life, in which he both documented and critiqued the increasing industrialization of agriculture. To construct a period of history in American agriculture, he used photographs from an extensive historical archive of Standard Oil New Jersey (SONJ), established during 1943-52. SONJ had commissioned this set of pictures to improve its public image. Harper was able to discuss the importance in his role as a researcher of being aware of how the SONJ commission could have influenced the photographers and shaped what ended up in the archive as photographers were instructed to show how agrarian societies worked with petroleum (Harper, 2003, p. 250). He highlights the ideological "shading" of the archive: the photos did not display problematic aspects of changing farm communities, but rather the more idyllic and stereotypic sides of rural life and agriculture such as landscapes, pasturing animals and women and men in their traditional roles.

The material and technical characteristics of photography at the time shaped the manner in which such ideological shading was constructed. Only very few of the pictures directly attempt to convey social processes, but even those that did not are ideologically interesting. For example, Harper (2003, p. 253) uses a photo of farm hands sitting at dinner in a 
farmhouse to show how photographers may, for technical reasons, distort a scene: the picture appears brighter and perhaps more optimistic than the actual scene it reflects. The dining room would never have been as intensively lighted as it appears in the photograph, but the lighting was required for the photographers to achieve depth in the image and to show everyone sitting at the table. Similarly, the heavy cameras of that time often required tripod use, which technically prevented much of what we are used to today, namely snapshots and on-the-spot pictures, as well as so-called street photography. The pictures therefore displayed little that was spontaneous, giving the archive something of an overall bucolic and even timeless sense of place. Similarly, portraits of farmhands Harper found in the SONJ archives frequently showed them "in poses reminiscent of Socialist Realism, as heroic common people" (Harper, 2003 , p. 254). This, again, was likely in large part an outcome of the technology as much as or more than a stylistic choice. During these times, photographs often were made with double lens reflex cameras. These are commonly carried at one's chest, with the photographer looking down into the camera, so the camera was usually lower than the subject, and tilted upwards when taking a picture, making the subjects appear larger than life (Becker, 1974, p. 23) The ideological element would likely have more to do with the selection of the resulting images as part of the archive. Or perhaps the photographers, aware of how the images would appear, were able to guess what would find favor with SONJ, letting the selection process take place at the time the photographs were made.

Becker (1974, p. 23) suggests that photographers' stylistic devices play a decisive role in how we perceive the resulting images, drawing on the example of Paul Strand's portraits of peasants from all over the world. Strand's eye-level camera perspective as well as his decision to let people pose in the ways they chose and felt comfortable with, created images that convey respect for the people he photographed. Although we do not want to go into technical details, we still believe the points made by Harper (2003) and Becker (1974) are too important to not consider here. Both authors emphasize that photographic techniques and the physical characteristics of camera itself, the conscious choices made about lighting, shadows and what to frame and what to leave out influence what we see. In the case of using historical pictures for our research, this would imply that we need to know about and consider how such factors as well as the photographic fashions of the time might have influenced picture taking and the outcomes we look at. The same lessons apply, of course, but may be more difficult to discern if we are using contemporary photographs or even those, we might create ourselves. The interplay of framing decisions and of materials and the technology is of importance for us if we are to use photography. But this does not mean that we all need to be skilled photographers to make informed interpretations: a little bit of awareness and information can 


\section{Studying Contexts}

go a long way in this regard. We will come back to this again later in this chapter. More generally, we need to think of visual images, old or new as artifacts of craft and construction-and not just as direct reflections of some reality-much as we have learned to do in our understanding of writing and writing styles as artifacts of craft and construction.

\section{Arriving at Photography and Arts}

We now will take the visual turn in our discipline in a different direction, suggesting-analogous to our discussion earlier in this chapter of more daring ways we might present our research results-even more daring approaches to using visuals. These approaches are inspired by disciplines outside the social sciences. Becker (1974, p. 6) argued that photography, although becoming more personal and artistic, has continued to be political whilst sociology, over the years, has become more academic and forgetful about documentary and other uses of photography. We would like to add that our own field, entrepreneurship research, never has had an explicit visual tradition. When researchers do occasionally make use of imagery, they mostly restrict themselves to extending techniques and approaches that are typical for qualitative analysis, perhaps illustrating their articles with pictures or providing straightforward analysis of some images (with a few notable exceptions as we outlined earlier). Still, doing context through imagery of whatever sorts can bring silenced stories and silenced voices to the fore (Berglund \& Wigren-Kristoferson, 2012). But work by people in other fields shows that we could do much more.

In stark contrast to the work we have described so far are projects and publications by photographers, artists and multi-artist research groups, to which we now turn. We want to point out that this is a selective review of photographers, projects and webpages that caught our attention as soon as we started to discuss how to apply the CPA to visualizing entrepreneurship. We do not lay claim to a systematic review, nor do we want to suggest that photographers or artists are "better" social scientists. Rather, we have been searching for different visual ways of "doing context" as researchers, i.e., for ways that would allow us to see, listen to, give voice to, portray, theorize and serve everyday entrepreneurs-and we believe that there is something we can learn from photographers and artists in this regard. We can use our agency as researchers to differently illustrate the agency of, for example, marginalized groups, to show their "normalcy" and "everydayness", or their interesting difference and variation and unique perspectives and thereby to make them part of the mainstream of what we study even as they cause us to challenge our taken-for-granted assumptions of what constitutes entrepreneurship. Also, the interpretations we outline in the following are ours, if not referenced, and we want to emphasize that neither of us has learnt, yet, how to read and critique photographs. We don't see this-for this 
moment and this purpose-as disadvantage, but as advantage: what we show throughout the next sections are our personal impressions and reactions (some rather emotional and passionate), as rather traditional entrepreneurship researchers to the works we have identified. We hope this speaks to some other entrepreneurship researchers in ways that more astute and sophisticated treatments by "professionals" might not and in general seemingly have not.

\section{Visualizing the Invisible}

Photography has from its beginnings been used as a tool to explore society (Becker, 1974). The German photographer August Sander, for example, started his main and unfinished artistic project "People of the 20th Century" during the Weimar Republic, aiming to find archetypes of every possible "type, social class, sub-class, job, vocation, privilege" (Berger, 2009 , p. 31). He assembled his photographs into seven groups, each with several subgroups: the farmer, the craftsman, the woman-where he managed to present women in both their traditional roles as wives and mothers but also as modern and emancipated working women (which to us already clearly illustrates the tensions between society's expectations and what women wanted for themselves that remain apparent in German society today (Welter, 2006)), the classes and professions, the artists, the big city and the "last human beings" (Die Photographische Sammlung/ SK Stiftung Kultur, 2017). The latter includes moving photographs of, in Sander's labelling, "idiots, the sick, the insane and matter" ("matter" including dead people and the death mask of his son), showing all those portrayed as "human beings", with-as we see his photographs nearly a century later-compassion towards his people, and without any negative connotations.

The same applies to his portfolio of "Traveling people" (those labeled "gypsies" and transients). His deeply human and unprejudiced (according to Walter Benjamin, cited in Berger, 2009, p. 31) perspective of seeing people did not conform or find favor with the Nazi regime, therefore an early publication from 1926, with 60 of his portraits, was taken out of circulation by the Nazis, and the printing plates were destroyed (Betancourt Nunez, 2018). After the Second World War, Sander added portfolios of the "persecuted" (Jews persecuted during the Nazi regime) and "political prisoners", which were taken by his son Erich Sander, himself a political prisoner for 10 years and who died in prison in 1944.

Sander's art was to show people as they are, approaching them respectfully without regard to the position they held in society. He nevertheless managed to point to their social differences and everyday life concerns: for example, with a touch "of irony" for the industrialist, or fear in the faces of the Jewish people that passed through his studio because they needed new passport photos (Betancourt Nunez, 2018, p. 16). John 


\section{Studying Contexts}

Berger, who admired Sander's work, also pointed to his apparent ease in relating to the people he photographed, asking: "What did August Sander tell his sitters before he took their pictures? And how did he say it so that they all believed him in the same way"? (Berger, 2009, p. 31). Alfred Döblin, as a novelist himself a deep chronicler of everyday city life and its tragedies in the 1930s, characterized Sander's photographs as a "philosopher's expressions; each one speaks for itself, and altogether in the way in which they are arranged, they are more eloquent than anything I could say", even suggesting that Sander "has succeeded in writing sociology not by writing, but by producing photographs" (Döblin, 2018, p. 39).

A more recent example of an impressive, but totally different, photographic investigation is Eskildsen and Rinne's (2009) book about the Roma peoples: between 2000 and 2006, the photographer (Eskildsen) and writer (Rinne) travelled to seven different countries (in chronological order of travels: Hungary, India, Greece, Romania, France, Russia, Finland), to document and learn about their lives in different societies and cultures. Roma have been travelling around for more than 600 years. They are one of the invisible ethnic minorities in most European countries, becoming visible only once they "disturb" our daily life. The "Roma Reisen" presents a vivid verbal and pictorial story of this largely invisible and silenced ethnic minority, which attempts to keep (some of) its traditions, both adapting to and defying the societies they live in, butas is apparent from the photographs-to which they do not belong. In Europe, many of the Roma minority, ca. 20 million people, are refugees or stateless and where they seem to be integrated into societies (as is the case with the Sinti in Germany), they often avoid showing that they belong to the Roma people. In such cases the "othering" of the Roma is a joint result of them being made invisible and their adaptation to this disparagement, creating something of a self-reinforcing cycle.

There are many examples of photographers offering visual interpretations of inequalities, violence, migration, gender and society, which go beyond documenting current affairs towards making present to us those otherwise marginalized as invisible and silent. We will describe in a bit more detail some of the varied works on migration that photographers have produced, as these strikingly illustrate many of the facets and nuances of pictorial approaches to a theme, suggesting potential for us, as entrepreneurship scholars, to attempt the inclusion of those "others" more typically disparaged, silenced or rendered invisible. These works present varied perspectives on migration, illustrating its diversity and the manifold reasons why people migrate. Projects range from worker migration in the U.S. in the wake of environmental catastrophes in the 1930s, as reflected in the works of Dorothea Lange, to the first wave of invited guest-worker migration within Europe, from Southern European to Northern European countries in the 1960 and 1970s, as represented by the works of John Berger and Jean Mohr, to the currently 
too-commonplace situations of people taking flight from wars, conflicts, economic distress and environmental disasters, represented by the Lampedusa and the atlas projects and by Ai Weiwei's art.

Dorothea Lange's "migrant mother" has become something of the visual icon for the domestic migration of working poor in the United States during 1935-1941. Lange, the daughter of second-generation immigrants from Germany (1895-1965), is one of the best-known documentarians covering the domestic migration of working poor in the U.S. during this time. She moved from successful portrait photography (she owned her own studio in San Francisco) to finding her passion doing social documentary, photographing-amongst other projects-the Great Depression in the 1930s. Her "guiding creed was the transformative and motivating power of seeing", and she was "driven by a deep belief that seeing the effects of injustice could help provoke reform and, perhaps, change the world" (Johnson, 2018, p. 15). Lange saw photography as her means to connect with others whom we might otherwise ignore, simply because we don't see them. The "Migrant Mother" (1936, https:// en.wikipedia.org/wiki/Florence_Owens_Thompson\#/media/File:LangeMigrantMother02.jpg) was taken while on an assignment for the Farm Security Administration to document the migrant workers and Dust Bowl refugees. Dorothea Lange contributed her pictures, the sociologist Paul Taylor, of the University of California at Berkeley, contributed his data and written reports. Although Lange was commissioned to visualize the "plight of white refugees", she "included Mexican migrants in California and black sharecroppers in the Deep South" and found "ways to report what she considered important hidden stories, regardless of whether her bosses wanted to hear them. Her insistence on exposing the relationship between racial discrimination and poverty, particularly in the South, drew criticism from the agency, which strove to assert the 'worthiness' of migrants by portraying them as Anglo-Saxon victims of natural events beyond their control, rather than as a multiracial group of hostages trapped in an unjust system" (Johnson, 2018, p. 18).

We now move to the 1970 s and to A Seventh Man, written by John Berger and photographed by Jean Mohr (Berger \& Mohr, 2016). They document and narrate the first wave of so-called "guest worker" migration within Europe, from Southern European countries to Northern Europe. The title refers to the statistic that in Germany and Great Britain, at that time, one of seven manual workers was an immigrant (Berger, 1975). Berger uses a multifaceted approach to visualize migration (Becker, 2002): poetry and constructing an archetypical story of a male migrant worker, nameless, but not faceless, because little details of the daily lives and work are narrated and presented visually through the book. Strikingly, Mohr's photographs are neither explained, referred to in the text nor analyzed explicitly. The narrative of the migrant worker is put into the broader context of work migrations, using statistics, Marxist 


\section{Studying Contexts}

theory about capitalist developments and the exploitation of labor. The photographs correspond to and add concreteness and presence to the analysis, but it is left to the reader to see and construct the connections. When the book was reedited in 2016, Berger, in his new foreword, reflected on the reception of the original publication, stating that sometimes, books become younger over the years. At the time of the original publication, Berger and Mohr wanted to initiate a political debate, and were hoping to contribute to strengthening the international solidarity of workers' movements. But media ignored the book and it was widely critiqued as unreliable because of its pamphlet format and seeming lack of "scientific" character. Interestingly, in Southern Europe the book found a different reception; it was translated into Turkish, Greek, Arabic, Portuguese, Spanish and Punjabi and widely read. These readers interpreted it as a "little book full of life stories, a series of lived moments-like a family album" (Berger, 2016, p. 8, translation by authors). What makes the book special to us is that it tells a timeless story of the two sides of work migration: its hopes and dreams as well as the homelessness and disappointments. This is just one reading of the book: its setup invites the readers and viewers to create their own meanings.

The next projects illustrate today's global movements of human flight, triggered by war and conflicts, poverty and disasters. The Migrant Image Research Group presents Lampedusa-Image Stories from the Edge of Europe (Migrant Image Research Group, 2017), a book assembling many different viewpoints on the dangerous migration across the Mediterranean Sea from African to Europe in the form of a photographic novel. It includes a wide array of narratives (strip cartoons, photographs), interviews and reflections by journalists and photographers from both sides of the Mediterranean, by artists, authors and migrants; stories of political engagement; and portrayals of statistical data. The project results from a collaboration of the artist Armin Linke, who took a team from the Karlsruhe University of Arts and Design when invited to Lampedusa. The resulting Migrant Image Research Group includes artists, authors, comic-strip designers and illustrators, photograph historians, visual designers, researchers, moviemakers and, ultimately, the publisher of their book. Their work aims at questioning and challenging existing pictorial representations of migrants. Lampedusa, the title of their book, refers to the small Italian island in the Mediterranean situated closest to Africa. It is the first European stop, which led to a huge influx of unauthorized migrants. The group focuses on this place and this event to illustrate how images can take on a life of their own and inform public opinion about refugees, at the same time presenting "other" visual and verbal narratives.

The atlas project, subtitled "Caught in Freedom", maps migration in different and unusual ways. It succeeds in showing some of the many faces of the journeys, the people undertaking these journeys and the 
hazards and difficulties they face in pursuit of their dreams. It stems from a project by Markert, Moser, and Scheuerlein (2016, www.behance.net/ gallery/22756225/FLUCHTATLAS), who were at the time design students at the University of Applied Sciences Würzburg-Schweinfurt. They started working on their atlas in summer 2014, nearly a year before Chancellor Angela Merkel opened German borders to refugees in early September 2015. The result is an unusual atlas, combining maps with facts on migration with individual stories that are not presented as single narratives, but as themes, drawing on photographs and illustrative quotes. In the words of one of the authors/designers: "Through the chapters Heimat (Home), Flucht (Escape) and Schutz (Protection) the reader accompanies the refugees on their seemingly endless way to freedom. Our project is based on interviews with refugees and comprehensive research. It is supposed to present a general view of this global problem, eliminate prejudices and help understanding the situation of refugees" (www.lilli-scheuerlein.de/work/fluchtatlas/). In our reading, this project is remarkable in that it portrays the humanity of the refugees by deeply contextualizing their journeys, but without reliance on classical portraiture of the sorts used in many works on migrants, and-we believetherefore managing to elicit empathy without evoking pity.

The Chinese artist Ai Weiwei is known for his political art and installations. Migration and flight are one of his recurring themes, not least because he also migrated from China, and currently lives in Berlin. Retrospectives in 2016 (Libero, www.palazzostrozzi.org/mostre/aiweiwei/?lang=en) and 2019 (Where is the revolution, www.kunstsammlung.de/en/ai-weiwei. html) included several of his works on refugees and flight: Reframe-an installation covering the windows of the Palazzo Strozzi in Florence with those fragile orange rescue dinghies that refugees use to cross the Mediterranean (www.palazzostrozzi.org/wp-content/uploads/2015/12/facciata1. jpg). Life Cycle-a monumental but fragile boat constructed out of bamboo and sisal ropes, drawing on Chinese traditions of kite making (www.kunstsammlung.de/uploads/pics/lifecycle_01.jpg). Plates and vases made in the tradition of the famous blue-and-white Chinese porcelain but with scenes from war, refugee camps, demonstrations, violence against migrants (Vartanian, 2018). Whilst Reframe and Life Cycle are direct in their messages to us, the vases and porcelains present a more subtle picture of the dark sides of human migration, at first glance appearing as traditional Chinese porcelains, at second glance offering insights into the perils and dangers of migration, thus inviting people to look closely.

Migration has also been widely researched in our own discipline, for example, in studies looking at immigrants in small firms (Jones \& Ram, 2010), ethnic minorities and their challenges in accessing labour markets (Waldinger, Aldrich, \& Ward, 1990); and, as a result, the higher prevalence rates of migrants setting up their own businesses (Li, Isidor, Dau, \& Kabst, 2018); transnational entrepreneurs who are grounded in several 


\section{0}

cultural and institutional contexts (Drori, Honig, \& Wright, 2009), and more recently refugee entrepreneurship (Shepherd, Saade, \& Wincent, 2019). We believe that the selection of projects we have briefly presented here remind us that there are many facets of the context of migration that remain invisible in our work. They show us the non-obvious and they make what is already obvious even more explicit.

However, we also see another, more hidden, story behind our discussion as the visual narratives move over time from a more documentary style towards art. Of course, this is a result of our selection. But nevertheless, we believe there is an additional explanation for this, namely, that we may have become tired of looking at the same pictures again and again. What does art do that a well written documentary report with pictures can't? The "blunt" way of showing poverty, death, war, directly and the overwhelming visual thrust of our times may have led to us being somewhat calloused toward brutal pictures like the little boy on the beach who drowned in the Mediterranean (https://en.wikipedia. org/wiki/Death_of_Alan_Kurdi) but still able to be moved by more subtle messages. To us, visualizing migration through fine art photography like the flight atlas and arts projects like Ai Weiwei's installations comes with empathy and emotion whilst at the same time luring us to look again and anew and, perhaps, more than once. The narratives offered are subtle-they invite us to reflect on our own lives as we make sense out of them, whilst showing the brutality and dangers of flight and linking these to the hopes and dreams of migration. This works in different ways from the more outspoken pictures oftentimes presented in media. To us, the projects presented here are very much in line with the CPA, as they make the people leaving their homes in hope of finding new ones visible, give voice to their pain, dreams, humiliation and humanity and neither disparage nor make heroes of them. We will now turn to explore how we read pictures and how that may change our perspectives.

\section{Using and Reading Images}

"Pictures do not speak. Silence is one of their preconditions, and how much more is this silence when the picture is of someone who might speak, but doesn't. Someone who might face us, but chooses to do otherwise. Silence becomes the activity of the picture itself, its charge. A shrouded head, turned away. A silence made visible" (Cole \& Sheikh, 2018, p. 10). But, of course, we can and have to make pictures speak, if we are to use them in our research. Our fascination and, at the same time, reluctance towards using imagery in research, may result from a lack of knowledge on how to interpret pictures. In this chapter, we already touched upon the difficulties involved in such interpretation (and also with the publication of related writings). To make it even more difficult, photographs cannot be easily read without knowing the background: they "contain 
information that can be identified and measured in many different ways; but they are also repositories of meaning that are as puzzling as they are fascinating" (Grady, 1996, p. 10). But, how can we "read" a photograph for our purposes? As entrepreneurship researchers most of us have had little or no training about any of this.

We need to accept that images can be read in different ways by different people and across different times and places. With the bounded stories and assertions, we try to make as social scientists, there are some approaches available to us to help readers and viewers understand the claims about the world we are attempting to portray jointly through our words and the pictures we may present. But what is at least as important is that the images we use in our work will always carry multiple meanings and may challenge peoples' perspective in ways that we can neither predict nor control. The craft of this may be in balancing the extent to which we guide reader/viewers' responses to what we show them versus that extent to which we encourage them to see thing beyond what we are able to describe or even to see ourselves. We conclude that there is no one accepted interpretation of imagery-similar to what Berger (2016) touched upon when alluding to the different reception of his book A Seventh Man in the Global North and South. Images gain their power from this "ability to carry multiple meanings and interpretations" (Patterson, 2011, p. 129). Moreover, they push us towards changing perspectives and to challenge what we have taken for granted as the "paramount reality" of everyday life (Berger \& Luckmann, 1966).

Take the example of two sky pictures, both showing colorful pink skies and clouds. One was taken in the hometown of one of the authors (www. instagram.com/p/Bfz5kAxgMQW/), the other one in Barcelona (www. instagram.com/p/Bgjhb5Tg4Lj/). When she showed both pictures to photographer friends living in Barcelona, their reaction was to admire the colorful sunset skies in both their hometowns. The one from the hometown was, however, taken early morning before sunrise in late winter, the one from Barcelona is indeed the afterglow of a sunset, in early spring. The conclusion: without context, we see what we are familiar with and what we have come to expect and take for granted as real and normal. We do this without much thought at all. Relating this back to entrepreneurship research, we suggest that pictures allow us to "see" more and differently in our research, providing us as viewers and users with a "richness of simultaneous, alternative interpretations of which the word can only dream" (Patterson, 2011, p. 132).

In speaking to us, images can benefit from and drive language. Cadava (2018, p. 52) suggests something similar to this when he reflects on the photographer Susan Meiselas' project "Learn to See", in which, together with students and teachers, she sets out a series of exercises to create awareness of how we see and what we see. He asserts that "(. . .) the image itself can never appear alone: it requires language to begin to give 


\section{Studying Contexts}

us a context through which we can start to situate the image in relation to the several traces that are sealed within it, like a kind of archive, like an alphabet that still needs to be read". However, Banks and Zeitlyn (2015) caution that "reading" images is in important ways unlike our typical reading of texts: while some of our understanding of imagery is learnedwe come to associate certain imagery (as we do with signs, for example) with certain meanings, these are context-specific and oftentimes fleeting. As photography has become ubiquitous and facilitated through mobile phone technology, social media theorists have also started to question the non-verbal nature of photography, pointing out that photographs have started to disappear into verbal communication, accompanying short messages or being the short message (Jurgenson, 2019).

While we all have different meanings to read into pictures, as entrepreneurship researchers we also want to transport our own meanings to the viewer and reader. We would need to decide whether and to what extent we should provide hints for the reading of images we present and when to leave that to the viewers and readers as Berger and Mohr, for example, do in their photo novellas or the photographers Albarrán and Cabrera with their fine arts series around time and memories. This is in any case always a matter of degree, as each of us always fills in the blanks that allow us to make sense of any image, however straightforward it might seem. The question is how we go about shaping and trying to delimit readers' interpretations and how strongly we try to do this in any specific case. Knowing some background about, for example, when and where pictures have been taken would shape how we situate them even if we are not familiar with the periods and histories to which they allude.

Such contextualization seems like a valuable tool for shaping our meaning making. We illustrate this with an example that Welter (2019) describes using the caricatures she collected for her entrepreneurship classes in the 1990s, but which cannot be understood without knowledge of the-then-historical, political and public discussions. One such example is the 1990s (visual) discussion around private equity firms as so-called locusts (Heuschrecken): this probably would raise some brows today, but nothing like the heated discussion of the 1990s. The full story behind these caricatures can only be understood with deeper knowledge of the-then-dominant political discussions and society's fears: when private equity firms started gaining a foothold on the German capital market from the mid-1990s onwards, they also bought into German Mittelstand companies. That raised public discussions around whether the Mittelstand would lose one of its typical characteristics-the social responsibility many of the smaller firms show towards their employees and their regions. Thus, if we depicted such caricatures in our texts and contextualized them with the background outlined previously, we would constrain and at the same time deepen the meaning making of the viewer, while making it more similar to ours. The ways in which we use 
images, and through which we more or less strongly attempt to shape viewer's responses to them, beg their own sets of questions about tradeoffs between the simple, the accurate and the general.

We walk a narrow path between tightly contextualizing images and leaving them to be read by others, because too much of being told the picture's contexts will constrain us and the viewers from "seeing" differently. With any image, there are layers of "doing context": these include the researchers, the ones photographed and the viewers. In an image, entrepreneurs might be "captured" as they do context. As photographers, we select our places and what to photograph as well as how to frame them and how to present them to people. When we include the photograph as part of our work as researchers, we are doing context in how we present and perhaps explain it. We are making a parallel set of choices by the images we decide not to include, perhaps because they do not seem to fit or support our primary narrative. Or, maybe we include some images that do not comport with the narrative in order to invite different or richer interpretations by others. The viewer (and reader) is doing context as they make sense of the image(s). How and when and even why we impose constraints remains an open question and is up to our personal and scientific preferences (and some academic traditions, we admit) including whether we can be happy with telling one story and having readers/viewers read something very different into it. (Of course, most of us need only read a few papers citing our own to recognize that this is inescapable: the only question is the matter of degree.) The photographic installations, projects and books we outlined in the previous section also suggest or imply that imagery asks for a different way of "writing". To us, one ideal would be along the lines of combining imagery with the voices of the people we study, thereby providing intimacy through inviting "analysis, imagination and memory" and creating stories that come alive (Harper, 2003, p. 258).

This is both a matter of researcher choice and of balance. If images are entirely decontextualized, visual stereotyping may occur. This refers to, for example, the-still dominant-tradition of non-governmental organizations working in poor countries using pictures of undernourished children as their main iconography for attracting funding, and thereby reproducing colonial stereotypes (Manzo, 2008). Children frequently are depicted on their own, leaving the impression that no support network of family and community exists (Fairey, 2018). Dorothea Lange described her approach to photographing using three simple imperatives: no arranged photographs, capturing the sense of place and capturing the sense of time in a photograph (Jeu de Paume, 2018). Also, pictures are gendered in more subtle ways than we (both as researchers and as viewers) will be able to recognize without some background information. Harper (2003, p. 256) discusses the authorship of individual photographs he used from the $\mathrm{SONJ}$ archive, discovering that men and the few 


\section{Studying Contexts}

women photographers that worked on the SONJ commission took different approaches: men ignored female activities, while the one woman photographer he had included in the sample of pictures he used for his study concentrated on women and a limited set of their activities, but still neglecting the wider picture of women's role on farms, such as caring for animals. Relatedly, women photographers often also achieve access to other groups than men, as has been shown in the war photography of famous female photographers who included the suffering of civilians in their portfolios of battle photographs, thus showing a different face of the inhumanity of war and making it more accessible to all of us (Tenz, 2019).

Finally, we may sometimes need to de-familiarize ourselves with our research and the people we study. "If something is in front of your eyes all the time, you can end up simply not seeing it" (Dymott, 2017, p. 204). This quote well illustrates our role as researchers: we repeatedly need to reflect on that which we take for granted, whether that is something we read or something we look at; and we may sometimes perform better in questioning what is normal if we are not familiar with the subject, the environment or the situation. This also applies to us using photography in our work: because this is not something most of us are familiar with (beyond the ubiquitous mobile phone and its ever more sophisticated cameras that make us "see" the world through its screen), we may be able to use it in different ways-but we can also seek out others with useful knowledge and skills to collaborate with us. Otherwise, we may end up being limited to using techniques such as photography in illustrating our written words in the manner that is typical of corporate reports (Preston, Wright, \& Young, 1996).

Better than this would be to emulate the sorts of picture essays that have been used occasionally in management disciplines (Preston \& Young, 2000) As our discussion to this point tries to suggest, we think there is a lot more we can do with images, and the novelty of this approach to our work promises a great deal of useful experimentation. We have already suggested, for example, that art presents the topic of migration in very different ways from documentary photography or our own research studies. Indeed, art helps us to detect new nuances in situations and themes that we are so familiar with that we no longer pay any attention to what we perceive as normal: art shows everyday issues in unfamiliar ways, making us aware of the strangeness in the familiar, slowing us down and inviting us to rethink (attributed to the Russian formalist Shklovsky, see Gurevitch, 1988, pp. 1195-1196).

\section{A Brave New Pictorial and Linguistic World?}

Throughout this chapter, we have discussed research approaches that we think will assist us in doing context in different ways than we are 
accustomed to, by making us more mindful of both linguistic and visual tropes and techniques. Just as with most other recent paths toward contextualizing entrepreneurship, researchers doing linguistics or using visual images follow in the wake of other disciplines. Interestingly, and in line with our repeated reference to earlier disciplinary debates throughout this book, the linguistic turn-and especially critical use of linguistic methods in entrepreneurship research-is not new, but has been recently renewed, sometimes without awareness of the earlier work. There is much less of a tradition of visual techniques in entrepreneurship research: only a few researchers have taken up such approaches. Too often, scattered prior attempts that applying a CPA using linguistics or visual approaches have failed to penetrate elite journals or to stimulate follow-on work. To give just one more example: Ron Mitchell (1996) drew on oral histories of entrepreneurs from the U.S. west, suggesting that such a focus on insider meanings would allow entrepreneurship researchers to demystify venturing and illustrate its common stories and shared interpretations. This paper has had surprisingly little influence, especially given Mitchell's status in our field. To us, this fascinating article is something of a standalone example of a critical stance that might have formed the foundation of a CPA but did not.

We think that this tendency to rediscover (sometimes repeatedly) methods and research approaches other (social) disciplines have previously put to good use may result partly from our increasingly narrow disciplinary training and education, which has been converging around business-school dominated methods and contents. We believe that we are observing an increasing tendency to police papers toward a fairly narrow swath of acceptable mainstream methods at the cost of sometimes squelching explorations of the richness inherent in "other" research approaches that have been used successfully in other disciplines. For example, when reviewing the still scarce literature on CL approaches in entrepreneurship research, we discovered not only that the CL technique had been used to study entrepreneurship, but also that some of this research has come from disciplines such as political science that are not central to entrepreneurship research. Similarly, as both authors of this book come from different backgrounds (a U.S. sociologist, with a background in business, and a German economist-management scholar turned small business researcher) we often discovered in our own discussions how our distinctive training and experiences as well as our (national) research cultures inform our views on the (research) world and the literatures we are familiar with and we tend to notice. This is true even though we both long have lived and operated in the world of mainstream entrepreneurship research. The lesson for us, and perhaps more broadly, is that we have missed out on an awful lot of interesting approaches and insights because of our tendency to focus on the "mainstream", however defined. 


\section{Studying Contexts}

\section{References}

Achtenhagen, L., Naldi, L., \& Melin, L. (2010). Business growth: Do practitioners and scholars really talk about the same thing? Entrepreneurship Theory and Practice, 34(2), 289-316.

Achtenhagen, L., \& Welter, F. (2003). Female entrepreneurship in Germany: Context, development and its reflection in German media. In J. E. Butler (Ed.), New perspectives on women entrepreneurs (pp. 71-100). Greenwich, CN: Information Age Publishing.

Achtenhagen, L., \& Welter, F. (2004). Linking the entrepreneurship discourse to its context: The development of entrepreneurship in Germany in the years 1997-2001. In M. Dowling, J. Schmude, \& D. zu Knyphausen-Aufsess (Eds.), Advances in interdisciplinary European entrepreneurship research (pp. 1-25). Münster: LitVerlag.

Achtenhagen, L., \& Welter, F. (2007). Media discourse in entrepreneurship research. In H. Neergaard \& J. P. Ulhoi (Eds.), Handbook of qualitative research methods in entrepreneurship (pp. 193-215). Cheltenham: Edward Elgar.

Achtenhagen, L., \& Welter, F. (2011). Surfing on the ironing board: The representation of women's entrepreneurship in German newspapers. Entrepreneurship \& Regional Development, 23(9-10), 763-786.

Ahl, H. (2002). The making of the female entrepreneur: A discourse analysis of research texts on women's entrepreneurship. Jönköping: Internationella Handelshögskolan.

Ahl, H. (2007). Sex business in the toy store: A narrative analysis of a teaching case. Journal of Business Venturing, 22(5), 673-693.

Akman, V. (2000). Rethinking context as a social construct. Journal of Pragmatics, 32(6), 743-759.

Allen, T. (2007). A toy store(y). Journal of Business Venturing, 22(5), 628-636.

Bach, H. (2001). The place of the photograph in visual narrative research. Afterimage, 29(3), 7.

Baker, T. (2007). Resources in play: Bricolage in the toy store(y). Journal of Business Venturing, 22(5), 694-711.

Baker, T., Aldrich, H., \& Liou, N. (1997). Invisible entrepreneurs: The neglect of women business owners by mass media and scholarly journals in the USA. Entrepreneurship \& Regional Development, 9(3), 221-238.

Baker, T., \& Welter, F. (2018). Contextual entrepreneurship: An interdisciplinary perspective. Foundations and Trends in Entrepreneurship, 14(4), 357-426

Banks, M., \& Zeitlyn, D. (2015). Visual methods in social research. London: Sage.

Bar, M. (2004). Visual objects in context. Nature reviews: Neuroscience, 5(8), 617-629.

Barberá-Tomás, D., Castello, I., de Bakker, F. G. A., \& Zietsma, C. (2019). Energizing through visuals: How social entrepreneurs use emotion-symbolic work for social change. Academy of Management Journal. Online early. doi:10.5465/ amj.2017.1488

Bateson, G., \& Mead, M. (1942). Balinese character: A photographic analysis (Vol. II). New York, NY: New York Academy of Bibliography.

Bazzanella, C. (2002). The significance of context in comprehension: The Wecase. Foundations of Science, 7(3), 239-254. 
Becker, H. S. (1974). Photography and sociology. Studies in Visual Communication, 1(1), 3-26.

Becker, H. S. (2002). Visual evidence: A seventh man, the specified generalization, and the work of the reader. Visual Studies, 17(1), 3-11.

Bell, E., \& Davison, J. (2013). Visual management studies: Empirical and theoretical approaches. International Journal of Management Reviews, 15(2), 167-184.

Berger, J. (1975). The seventh man. Race \& Class, 16(3), 251-257.

Berger, J. (2009). The suit and the photograph. In J. Berger (Ed.), About looking (pp. 31-40). London: Bloomsbury.

Berger, J., \& Mohr, J. (2016). Der siebte mensch. Eine geschichte über migration und arbeit in Europa (New ed.). Frankfurt am Main: Fischer Taschenbuch.

Berger, P. L., \& Luckmann, T. (1966). The social construction of reality: A treatise in the sociology of knowledge. New York, NY: Doubleday and Company.

Berglund, H. (2007). Researching entrepreneurship as lived experience. In H. Neergard \& J. P. Ulhoi (Eds.), Handbook of qualitative research methods in entrepreneurship (pp. 75-93). Cheltenham: Edward Elgar.

Berglund, H. (2015). Between cognition and discourse: Phenomenology and the study of entrepreneurship. International Journal of Entrepreneurial Behavior \& Research, 21(3), 472-488.

Berglund, K. A. E., \& Wigren-Kristoferson, C. (2012). Using pictures and artefacts in a PAR process to disclose new wor(l)ds of entrepreneurship. Action Research, 10(3), 276-292.

Betancourt Nunez, G. (2018). August Sander and the people of the 20th century. In M. D. L. Shoah (Ed.), Persecuted/persecutors: People of the 20th century (pp. 15-17). Göttingen: Steidl.

Boxenbaum, E., Jones, C., Meyer, R. E., \& Svejenova, S. (2018). Towards an articulation of the material and visual turn in organization studies. Organization Studies, 39(5-6), 597-616.

Brännback, M., \& Carsrud, A. (2016). Understanding entrepreneurial cognitions through the lenses of context. In F. Welter \& W. B. Gartner (Eds.), A research agenda on entrepreneurship and context (pp. 16-27). Cheltenham: Edward Elgar.

Broth, M. (2008). The studio interaction as a contextual resource for TVproduction. Journal of Pragmatics, 40(5), 904-926.

Broth, M., \& Mondada, L. (2013). Walking away: The embodied achievement of activity closings in mobile interaction. Journal of Pragmatics, 47(1), 41-58.

Cadava, E. (2018). Learning to see. In Susan Meiselas: Mediations (pp. 41-68). Paris, Barcelona, Bologna: Damiani.

Chandra, Y. (2017). Social entrepreneurship as institutional-change work: A corpus linguistics analysis. Journal of Social Entrepreneurship, 8(1), 14-46.

Clarke, J. S. (2011). Revitalizing entrepreneurship: How visual symbols are used in entrepreneurial performances. Journal of Management Studies, 48(6), 1365-1391.

Cohen, L., \& Musson, G. (2000). Entrepreneurial identities: Reflections from two case studies. Organization, 7(1), 31-48.

Cole, T., \& Sheikh, F. (2018). Human archipelago. Göttingen: Steidl.

Collier, J. (1957). Photography in anthropology: A report on two experiments. American Anthropologist, 59(5), 843-859. 


\section{Studying Contexts}

Damgaard, T., Piihl, J., \& Klyver, K. (2004). The dramas of consulting and counselling the entrepreneur. In D. Hjorth \& C. Steyaert (Eds.), Narrative and discursive approaches in entrepreneurship (pp. 160-176). Cheltenham: Edward Elgar.

Dannreuther, C., \& Perren, L. (2015). The rhetoric of power. In T. Baker \& F. Welter (Eds.), The Routledge companion to entrepreneurship (pp. 376-390). London: Routledge.

de Kok, B. C. (2008). The role of context in conversation analysis: Reviving an interest in ethno-methods. Journal of Pragmatics, 40(5), 886-903.

Dey, P., \& Steyaert, C. (2010). The politics of narrating social entrepreneurship. Journal of Enterprising Communities: People and Places in the Global Economy, 4(1), 85-108.

Die Photographische Sammlung/SK Stiftung K. (Ed.). (2017). August Sander: Menschen des 20: Jahrhunderts: Ein Kulturwerk in Lichtbildern eingeteilt in sieben Gruppen. Munich: Schirmer/Mosel.

Döblin, A. (2018). What one should recognize here. In Mémorial de la Shoah (Ed.), Persecuted/persecutors: People of the 20th century (p. 39). Göttingen: Steidl.

Dourish, P. (2004). What we talk about when we talk about context. Personal and Ubiquitous Computing, 8(1), 19-30.

Drakopoulou-Dodd, S., \& De Koning, A. (2015). Enacting, experimenting and exploring metaphor methodologies in entrepreneurship. In H. Neergaard \& C. Leitch (Eds.), Handbook of qualitative research techniques and analysis in entrepreneurship (pp. 109-138). Cheltenham: Edward Elgar.

Drori, I., Honig, B., \& Wright, M. (2009). Transnational entrepreneurship: An emergent field of study. Entrepreneurship Theory and Practice, 33(5), 1001-1022.

Dupret, B., \& Ferrié, J. N. (2008). Legislating at the shopfloor level: Background knowledge and relevant context of parliamentary debates. Journal of Pragmatics, 40(5), 960-978.

Dymott, E. (2017). Silver and salt. London: Jonathan Cape.

Eikhof, D. R., Summers, J., \& Carter, S. (2013). Women doing their own thing: Media representations of female entrepreneurship. International Journal of Entrepreneurial Behaviour \& Research, 19(5), 547-564.

Eskildsen, J., \& Rinne, C. (2009). Die romareisen (Le romané phirimàta). Göttingen: Steidl.

Fairey, T. (2018). Whose photo? Whose voice? Who listens? Giving, silencing and listening to voice in participatory visual projects. Visual Studies, 33(2), 111-126.

Fletcher, D. (2007). Toy story: The narrative world of entrepreneurship and the creation of interpretive communities. Journal of Business Venturing, 22(5), 649-672.

Fletcher, D., \& Watson, T. J. (2007a). Entrepreneurship, management learning and negotiated narratives: Making it otherwise for us: Otherwise for them. Management Learning, 38(1), 9-26.

Fletcher, D., \& Watson, T. J. (2007b). Voice, silence and the business of construction: Loud and quiet voices in the construction of personal, organizational and social realities. Organization, 14(2), 155-174.

Gartner, W. B. (2007). Entrepreneurial narrative and a science of the imagination. Journal of Business Venturing, 22(5), 613-627. doi:10.1016/j.jbusvent.2006. 10.003 
Gartner, W. B. (2008). Entrepreneurship: Hop. Entrepreneurship Theory and Practice, 32(2), 361-368.

Gartner, W. B. (2015). Ten haiku's on the internet's own boy. M@n@gement, 18(5), 370-371.

Grady, J. (1996). The scope of visual sociology. Visual Studies, 11(2), 10-24.

Gurevitch, Z. D. (1988). The other side of dialogue: On making the other strange and the experience of otherness. American Journal of Sociology, 93(5), 11791199. doi:10.1086/228868

Harper, D. (1987). Working knowledge: Skill and community in a small shop. Chicago, IL: University of Chicago Press.

Harper, D. (1988). Visual sociology: Expanding sociological vision. The American Sociologist, 19(1), 54-70.

Harper, D. (2003). Framing photographic ethnography: A case study. Ethnography, 4(2), 241-266.

Harper, D. (2012). Visual sociology. Abingdon: Routledge.

Harper, D. (2016). Good company: A tramp life (3rd ed.). Abingdon; New York, NY: Routledge.

Hjorth, D. (2007). Lessons from Iago: Narrating the event of entrepreneurship. Journal of Business Venturing, 22(5), 712-732.

Hjorth, D., \& Steyaert, C. (2004a). Foreword and acknowledgements. In D. Hjorth \& C. Steyaert (Eds.), Narrative and discursive approaches in entrepreneurship (p. VIII). Cheltenham: Edward Elgar.

Hjorth, D., \& Steyaert, C. (2004b). Introduction. In D. Hjorth \& C. Steyaert (Eds.), Narrative and discursive approaches in entrepreneurship (pp. 1-7). Cheltenham: Edward Elgar.

Hjorth, D., \& Steyaert, C. (Eds.). (2010). The politics and aesthetics of entrepreneurship. Cheltenham: Edward Elgar.

Hosking, D. M., \& Hjorth, D. (2004). Relational constructionism and entrepreneurship: Some key notes. In D. Hjorth \& C. Steyaert (Eds.), Narrative and discursive approaches in entrepreneurship (pp. 255-268). Cheltenham: Edward Elgar.

Jeu de Paume. (2018). Dorothea Lange, politics of seeing: Exhibition Portfolio. Paris: Jeu de Paume.

Johnson, D. H. (2018). Dorothea Lange and the politics of seeing. In A. Pardo \& J. Golbach (Eds.), Dorothea Lange: Politics of seeing (pp. 15-25). London; New York, NY: Prestel Publishing.

Jones, T., \& Ram, M. (2010). Ethnic variations on the small firm labour process. International Small Business Journal, 28(2), 163-173.

Jurgenson, N. (2019). The social photo: On photography and social media. New York, NY: Verso Books.

Katz, J. A. (2004). Reading the storybook of life: Telling the right story versus telling the story rightly. In D. Hjorth \& C. Steyaert (Eds.), Narrative and discursive approaches in entrepreneurship (pp. 233-244). Cheltenham: Edward Elgar.

Krennmayr, T. (2015). What corpus linguistics can tell us about metaphor use in newspaper texts. Journalism Studies, 16(4), 530-546.

Labov, W. (1970). The study of language in its social context. Berlin: Springer.

Li, C., Isidor, R., Dau, L. A., \& Kabst, R. (2018). The more the merrier? Immigrant share and entrepreneurial activities. Entrepreneurship Theory and Practice, 42(5), 698-733. 


\section{Studying Contexts}

Lindh de Montoya, M. (2004). Driven entrepreneurs: A case study of taxi owners in Caracas. In D. Hjorth \& C. Steyaert (Eds.), Narrative and discursive approaches to entrepreneurship (pp. 57-79). Cheltenham: Edward Elgar.

Ljunggren, E., \& Alsos, G. A. (2001). "Media expressions of entrepreneurs: Frequency, content and appearance of male and female entrepreneurs." Paper presented at the Babson-Kauffman Entrepreneurship Research Conference, Jönköping, Sweden.

Manzo, K. (2008). Imaging humanitarianism: NGO identity and the iconography of childhood. Antipode, 40(4), 632-657

Markert, L., Moser, Y., \& Scheuerlein, L. (2016). Fluchtatlas: Gefangen in der Freiheit. Frankfurt am Main: Büchergilde Gutenberg.

McHoul, A. (2008). Questions of context in studies of talk and interaction: Ethnomethodology and conversation analysis. Journal of Pragmatics, 40(5), 823-826.

McHoul, A., Rapley, M., \& Antaki, C. (2008). You gotta light? On the luxury of context for understanding talk in interaction. Journal of Pragmatics, 40(5), 827-839.

Mead, M. (1995). Visual anthropology in a discipline of words. In P. Hockings (Ed.), Principles of visual anthropology (Vol. 3, pp. 3-10). The Hague: Mouton.

Migrant Image Research Group (Ed.) (2017). Lampedusa: Bildgeschichten vom Rande Europas. Leipzig: Spector.

Mitchell, R. K. (1996). Oral history and expert scripts: Demystifying the entrepreneurial experience. Journal of Management History, 2(3), 50-67.

Mooshammer, H. (2015). Other markets: Sites and processes of economic pressures. In P. Mörtenböck, H. Mooshammer, T. Cruz, \& F. Forman (Eds.), Informal world markets: The architecture of economic pressure (pp. 17-32). Rotterdam: NAI010 Publishers.

O'Connor, E. S. (2007). Reader beware: Doing business with a store(y) of knowledge. Journal of Business Venturing, 22(5), 637-648.

Parkinson, C., \& Howorth, C. (2008). The language of social entrepreneurs. Entrepreneurship \& Regional Development, 20(3), 285-309.

Parkinson, C., Howorth, C., \& Southern, A. (2017). The crafting of an (un) enterprising community: Context and the social practice of talk. International Small Business Journal, 35(4), 385-404.

Patterson, S. W. (2011). A picture held us captive: The later Wittgenstein and visual argumentation. Cogency, 2(2), 105-134.

Perren, L., \& Dannreuther, C. (2012). Political signification of the entrepreneur: Temporal analysis of constructs, agency and reification. International Small Business Journal, 31(6), 603-628.

Perren, L., \& Jennings, P. L. (2005). Government discourses on entrepreneurship: Issues of legitimization, subjugation, and power. Entrepreneurship Theory and Practice, 29(2), 173-184.

Pink, S. (2003). Interdisciplinary agendas in visual research: Re-situating visual anthropology. Visual Studies, 18(2), 179-192.

Preston, A. M., Wright, C., \& Young, J. J. (1996). Imag [in] ing annual reports. Accounting, Organizations and Society, 21(1), 113-137.

Preston, A. M., \& Young, J. J. (2000). Constructing the global corporation and corporate constructions of the global: A picture essay. Accounting, Organizations and Society, 25(4-5), 427-449. 
Roundy, P. T. (2016). Start-up community narratives: The discursive construction of entrepreneurial ecosystems. The Journal of Entrepreneurship, 25(2), 232-248.

Roundy, P. T. (2019). Rust belt or revitalization: Competing narratives in entrepreneurial ecosystems. Management Research Review, 42(1), 102-121.

Roundy, P. T., \& Asllani, A. (2018). The themes discourse of entrepreneurship: A data analytics approach. Innovation, Entrepreneurship and Organizations' Business Performance, 14(3), 127-158.

Roundy, P. T., \& Asllani, A. (2019). Understanding the language of entrepreneurship. Journal of Economic and Administrative Sciences, 35(2), 113-127.

Shepherd, D. A., Saade, F. P., \& Wincent, J. (2019). How to circumvent adversity? Refugee-entrepreneurs' resilience in the face of substantial and persistent adversity. Journal of Business Venturing. Online early. doi:10.1016/j. jbusvent.2019.06.001

Shepherd, D. A., \& Wiklund, J. (2019). Simple rules, templates, and heuristics! An attempt to deconstruct the craft of writing an entrepreneurship paper. Entrepreneurship Theory and Practice. Online early. doi:10.1177/ 1042258719845888

Smith, R. (2014). Images, forms and presence outside and beyond the pink ghetto. Gender in Management, 29(8), 466-486.

Smith, R. (2015a). Con'text'ualizing images of enterprise: An examination of 'visual metaphors' used to represent entrepreneurship in textbooks. In H. Neergaard \& C. Leitch (Eds.), Qualitative research techniques and analysis in entrepreneurship (pp. 139-169). Cheltenham: Edward Elgar.

Smith, R. (2015b). Entrepreneurship and poetry: Analyzing an aesthetic dimension. Journal of Small Business and Enterprise Development, 22(3), 450-472.

Smith, R. (2015c). Seeing the light: Using visual ethnography in family business settings. Family Business Review, 28(1), 76-82.

Smith, R., \& Anderson, A. R. (2003, June 4-8). "Conforming non-conformists: Semiotic manifestations of an entrepreneurial identity." Paper presented at the Babson Kauffman Entrepreneurship Research Conference. Boston, MA.

Smith, R., \& Anderson, A. R. (2007a). Daring to be different: A dialogue on the problems of getting qualitative research published. In H. Neergaard \& J. P. Ulhøi (Eds.), Handbook of qualitative research methods in entrepreneurship (pp. 434-459). Cheltenham: Edward Elgar.

Smith, R., \& Anderson, A. R. (2007b). Recognizing meaning: Semiotics in entrepreneurial research. In H. Neergaard \& J. P. Ulhøi (Eds.), Handbook of qualitative research methods in entrepreneurship (pp. 169-192). Cheltenham: Edward Elgar.

Smith, R., \& Neergaard, H. (2015). Telling business stories as fellowship-tales. International Journal of Gender and Entrepreneurship, 7(2), 232-252.

Steyaert, C. (2007). Of course that is not the whole (toy) story: Entrepreneurship and the cat's cradle. Journal of Business Venturing, 22(5), 733-751.

Tenz, C. (2019, March 8). On the frontlines with women war photographers. Retrieved from https://p.dw.com/p/3EgMN

Vartanian, H. (2018). Picturing Ai Weiwei in Istanbul. Hyperallergic. Retrieved from https://hyperallergic.com/420114/ai-weiwei-on-porcelain-sakipsabanci-museum/

Waldinger, R. D., Aldrich, H., \& Ward, R. (1990). Ethnic entrepreneurs: Immigrant business in industrial societies. Newbury Park, CA: Sage. 


\section{Studying Contexts}

Welter, F. (2006). Women's entrepreneurship in Germany: Progress in a still traditional environment. In C. G. Brush, N. Carter, E. Gatewood, P. Greene, \& M. Hart (Eds.), Growth-oriented women entrepreneurs and their businesses (pp. 128-153). Cheltenham: Edward Elgar.

Welter, F. (2019). The power of words and images: Towards talking about and seeing entrepreneurship and innovation differently. In D. Audretsch, E. Lehmann, \& A. N. Link (Eds.), A research agenda for entrepreneurship and innovation (pp. 179-196). Cheltenham: Edward Elgar.

Welter, F., \& Gartner, W. B. (Eds.). (2016). A research agenda for entrepreneurship and context. Cheltenham: Edward Elgar.

Welter, F., \& Lasch, F. (2008). Entrepreneurship research in Europe: Taking stock and looking forward. Entrepreneurship Theory and Practice, 32(2), 241-248.

\section{Websites}

Retrieved 25 August, 2019, from www.lilli-scheuerlein.de/work/fluchtatlas/ Retrieved 25 August, 2019, from www.kunstsammlung.de/en/ai-weiwei.html

Retrieved 7 September, 2019, from www.kunstsammlung.de/uploads/pics/lifecycle_ 01.jpg

Retrieved 25 August, 2019, from www.behance.net/gallery/22756225/FLUCHTATLAS

Retrieved 30 August, 2019, from www.palazzostrozzi.org/mostre/aiweiwei/? lang=en

Retrieved 30 August, 2019, from www.palazzostrozzi.org/wp-content/uploads/ 2015/12/facciata1.jpg

Retrieved 30 August, 2019, from https://photovoice.org/

Retrieved 30 August, 2019, from https://en.wikipedia.org/wiki/Death_of_Alan_ Kurdi

Retrieved 11 September, 2019, from www.instagram.com/p/Bfz5kAxgMQW/

Retrieved 11 September, 2019, from www.instagram.com/p/Bgjhb5Tg4Lj/ 


\section{Part IV \\ Going Forward}


$\Longrightarrow$ Taylor \& Francis

Taylor \& Francis Group

http://taylorandfrancis.com 


\section{Why It's Hard to Look Back Once You Have Embraced Contexts}

It is our experience-and one that has been shared with us by a number of other entrepreneurship researchers-that once you engage in attempting to contextualize your work, it becomes hard to see entrepreneurship research through any other lens. Looking back at our own earlier work, many of us are filled with the recognition that our urge to quickly create widely generalizable findings caused us to miss too many opportunities to pay attention to context and thereby perhaps build more profound generalizations over time. In this final chapter, we briefly recap our lessons learned while working on this book and offer some new opportunities for contextualizing entrepreneurship in a manner that can lead to more theoretically robust and practically useful theory.

\section{Where We Stand Now}

Writing this book has led to many discoveries for both of us. First, the exciting discovery that there is a great deal of interesting and potentially useful research getting published that does not much celebrate or privilege or even care much about the SVM or about serving those who are already well-taken care of by both their circumstances and our work. For example, researchers are studying gender in increasingly insightful ways (of course, we still wish women and underrepresented minorities were more prevalent in the SVM!), and they are bringing mindful attention to context in studies of informality, the construction of places, the use of language, resourcefulness, identity, commitments to social good and a variety of other topics. They are using sophisticated, well-worn and highly legitimate methods and they are also trying out novel approaches, innovating around language and imagery and forms of artistic expression across different parts of the research process. This is an exciting time to be involved in entrepreneurship research.

Our second, more frustrating discovery is about how much of contemporary research imagines and engages with only a narrowly bounded range of the heterogeneous entrepreneurship we find around us whereever we go. Providing strong evidence for this continuing focus, Aldrich and 


\section{Going Forward}

Ruef (2018) recently critically examined the prevalence of two indicators of a rarefied form of the SVM-venture capital financing and initial public offerings-in articles published in the Journal of Business Venturing (JBV), Entrepreneurship Theory and Practice (ETP), Strategic Entrepreneurship Journal (SEJ), Strategic Management Journal (SMJ), Academy of Management Journal (AMJ) and Academy of Management Review (AMR) from 1990 (later for SEJ, which did not exist in 1990) to 2017. What they label the "obsession with IPOs and VCs" (Aldrich \& Ruef, 2018 , p. 459) is evidenced by the fact that between $40-50 \%$ of articles in JBV and SEJ mention one or both of these very rare phenomena, with percentages in ETP being more varied, but above $70 \%$ recently. During this time $58 \%$ of entrepreneurship articles in a general management journal, AMJ, discussed IPOs or VCs, while SMJ and AMR had somewhat lower numbers. Remarkably, this "obsession" has persisted during a time when VC funding and IPOs not only represented a vanishingly small percentage of entrepreneurship in the first place, but have also undergone steep declines in recent years. Thus, despite our optimistic portrayal and review of some of the "other" research that has been published during the last decade or so, any rumors of the death of researchers' lust for gazelles and unicorns are surely overstated.

Part of the reason for what might seem a disjuncture between the literature we have discussed and Aldrich and Ruef's (2018) findings is that they focused on a selection of elite entrepreneurship and general management journals, while we have drawn much more broadly across literatures and outlets. A higher focus by elite outlets on work that serves the status quo and privilege is in keeping with our earlier discussion of what shapes the answers to the question: "who does our research serve"? Despite the progress we have seen, the struggle—as we see it—is not yet won. It may be that the underrepresentation in elite journals of work embracing a broader empirical domain predicts the continued "ghettoization" of subfields of entrepreneurship research that are built on critical concern with context.

On the one hand, it seems almost cruel to ask a field like entrepreneurship, which has only become legitimate quite recently, to open itself to a cacophony of voices aiming to broaden the central research object of the field. But on the other hand, our field contains many people who share our concern about research focusing on the SVM becoming increasingly boring in its narrowness, increasingly useless and perhaps on the wrong side of concerns about inequality and power. More of these voices are doing research on "outliers" to the SVM than is typically visible to us. Much of this diversity appears to stem from the globalization of the field and the multifold perspectives brought in by scholars from "other" cultures, and by those not trained or fully socialized to our increasingly narrow paradigms and methods. Again, it is hard to imagine anyone ready to give birth to—or to saddle up a gazelle or a unicorn—reaching for 
one of our journals for useful insights. It is only slightly easier to imagine those in public policy roles seeking out and acting directly on the advice to found in management journals. Perhaps, in entrepreneurship, we still remain a more practically oriented lot than those in most other management fields (Baker \& Pollock, 2007). At least we hope so. Roughly speaking, we seem over several decades to have gone from an early concern with practice and little regard for theory or rigor, to great concern for rigor, some concern for theory and little care for practice. At the moment, however, our field seems poised for a great push forward toward work that is theoretically interesting, methodologically creative and tied to "practice" construed in the broadest possible way. Indeed, despite the patterns documented by Aldrich and Ruef (2018), some of this work is making its way into elite journals. It is hard not to be excited by the promise in the air, and again, hard to step away from thinking about how to do contexts in ways that will challenge our assumptions, let us build better and more useful theories, and avoid serving as ideologists for the status quo (something that should be anathema for anyone interested in entrepreneurship as a source of change).

In this book, we have placed entrepreneurship researchers' efforts to contextualize their work into the context (pun acknowledged) of some other fields that have grappled in interesting ways with similar issues, drawing on and extending work we have begun in Baker and Welter (2018). We have summarized much of the pertinent empirical work in entrepreneurship, as well as a number of reflective essays that have provided frameworks for understanding the dimensions of context to which we might attend. We describe the idea of entrepreneurs doing contexts through processes of enacting, and through how they talk about and see elements of their environments.

Using the inescapable tradeoff between the goals of simplicity, accuracy and generality, as well as issues of cultural relativity and local meaning from anthropology, we claimed that contextualization is essentially unbounded. This forces researchers to make choices-albeit sometimes unconsciously-about how contexts will figure into their research. We described this as researchers doing contexts. Much of the rest of the book develops some ideas around what we call a Critical Process Approach to doing contexts as researchers. We argued that by asking questions about who our research serves we can illuminate some of the power dynamics that have supported many of the assumptions we now take for granted and also make choices that help to challenge these assumptions through contextualization. Our claim is that research driven by a CPA is likely to improve not only the quality of our science but also to make it more broadly useful, especially to people who do not enjoy circumstances of power or control over substantial resources.

To provide some guidance toward CPA-driven research, we explored some heuristics for thinking about what sorts of research to do. A great 


\section{Going Forward}

deal of novel work is and can be done using the same tools and methods that we already use everyday. But in the spirit of thinking about how asking broader questions might suggest novel (to entrepreneurship) methods, we described some novel—and we think potentially quite useful-approaches from linguistics, visual disciplines and the arts.

\section{And Where Should We Go?}

Our thinking about where we should go is, unsurprisingly, conditioned by our discussion of the CPA. Research which studies the "other", be that another cultural, institutional or social context, or other forms of entrepreneurship, forces us to revisit our understanding of entrepreneurship. With our own cultural backgrounds, our gut response is to see an entrepreneur as someone who creates jobs, is innovative and (often) uses high technology - and this is what much entrepreneurship research has focused on. This has too often led to the othering of all that does not fit the norm of being male, high-tech, high-growth, high-innovation, attracting big equity investments, and aiming for "exit" events such as IPOs. The "other" entrepreneurship (for example, rural, informal, women, disabled, in peripheral regions, by members of oppressed religious or ethnic groups, low-technology, struggling, informal, barely getting by, community-based, altruistic) cannot-for scientific or practical purposes-simply be defined and limited by their differences from what is considered the norm. Instead, they provide a rich tableau of what constitutes entrepreneurship and its everydayness in themselves.

We need to get away from "othering" everything which does not fit our existing models and research interests, and instead accept the challenges of incorporating the astounding varieties of entrepreneurship into our theories and research approaches (Gartner, 2004). This is where the Critical Process Approach can help us: by expanding the empirical scope of our research in ways that challenges and displaces some of our own dearly-held assumptions. In terms of the S-A-G framework, the CPA enacts the world as messier and therefore as "more real", with the promise of improving accuracy at the short (and perhaps longer) term cost of sacrificing simplicity and perhaps generalizability. Only time will tell where the current drive to contextualize will leave the balance between simple, accurate and general. As long as we accept that entrepreneurship is much more heterogeneous and varied than our theories consider, we will have to accept that generalizing across people and contexts is a theoretical goal that remains well beyond our grasp. The real world of entrepreneurship is more complex and more interesting than the mainstream research in our field allows. It is time for us to try viewing the core of this reality as the efforts and struggles of everyday entrepreneurs everywhere as suggested by Welter, Baker, Audretsch, and Gartner (2017). Our theories, bereft of much promise of helping anyone, are simply not good 
enough. They need to be rattled to the core by the cacophony of critical voices and rebuild to a higher standard.

This book leaves a lot undone. We believe that incorporating more of the "other" research approaches into entrepreneurship studies will help us identifying exciting new research avenues. Current discussions around the multiplicity of contexts on and across different levels can make the empirical challenges of contextualizing entrepreneurship research appear intractably complex. Much of the problem can characterized as beginning with the clichéd tension between not being able to see the forest for the trees versus not being able to see the trees for the forest, and by both the promise and difficulties of seeing both at once. In addition, contextualizing entrepreneurship also throws into relief the dominance of quantitative methods in entrepreneurship research. While some authors argue that quantitative methods and testable hypotheses help the field as such to maintain legitimacy, others have argued that entrepreneurship research needs to understand more about the phenomena by assembling what is labelled "descriptive" evidence, requiring more research which aims at understanding the phenomenon from the perspective of those engaged in it. Some have even argued that contextualization is fundamentally inductive and qualitative. We disagree. In simple terms, while qualitative studies can get directly at contexts as they are lived and enacted by entrepreneurs, careful quantitative research can get at many of the same realities by cross-context comparisons. Primary differences emerge in the sorts of revelations that are typical with different methods. The approach we have presented in this book supports a rich model of "multi-level research", and challenges us to continue to develop productive ways to think about and guide the interplay of qualitative and quantitative methods as well as the interplay of abductive and deductive reasoning in contextualizing entrepreneurship research and theory.

We are hopeful that, with the renewed focus of our field on contextualizing entrepreneurship, some of the lenses and methods we touched upon in this book, such as those drawn from linguistics, will once more gain importance. We also hope that visual methods will begin to play a more important role in how we do context. The field's increasing awareness regarding language, imagery and their manifold ways of shaping our understanding of entrepreneurship will serve us well by making other voices visible and heard. This holds some promise of making our research relevant (and interesting) again. We support Alvesson and Kärreman's (2000) suggestion regarding the desirability of "some degree of pragmatism" in this regard. Regardless of whichever linguistic technique or visual methods entrepreneurship researchers employ, the emphasis on language, words, written texts, signs, photographs, other images, whether moving or still, is valuable in itself because it draws our attention to the institutional, historical and situational contexts we all move in and construct with our use of words and images. There are no purely visual or 


\section{Going Forward}

verbal disciplines (Mitchell, 1995). Rather, it is the interaction between the verbal, visual (and also the material) that shapes entrepreneurship, and our research approaches will improve as we build these elements into our work. In terms of ways of seeing, explaining and portraying the world of entrepreneurship, we have been taught to privilege the simple as the path to the accurate. It is high time to recognize and respond, in our approaches to research, to the rich complexities of what we have before us to study.

That goes hand in hand with exciting new research themes that we think may be relevant and interesting. For one, we need even more work on theorizing contexts to broaden the entrepreneurship domain towards more of the lived reality of everyday entrepreneurs (and, we want to repeat, more complexity): theorizing that pushes us towards broadening our understanding of what is usefully to be included in the domain of entrepreneurship research. One theme that has recently captured our own interest is extending our work to questions like how contexts are constructed through uses of the past as reflected in memories and traditions, through mapping the structures of places and their impact on entrepreneurship in novel ways, incorporating architecture and cartography; through power as shown, for example, in public debates and the language used to glorify certain contexts (such as the SVM) over others. In addition, the rapid digitization of our economies and societies poses its own sets of challenges and opportunities: for example, how do we study and theorize the (apparent) predominance of digital technologies, virtual worlds and the seeming possibilities of greater independence from "time and space"? Will virtual reality change how entrepreneurs and we as researchers do contexts?

Seeing and looking - we have only just managed to take a first step down this path. How, for example, might we incorporate the "unseen" into our research? Images leave things out, sometimes things cannot be seen, and sometimes they are deliberately kept out of sight. The visual is intertwined deeply with memory: "Our looking is haunted by what we once saw" (Cousins, 2017, p. 385). What are the implications once we start applying such lessons from others fields to understanding entrepreneurship and entrepreneurs doing contexts? Schumpeterian gales of creative destruction are relatively rare events amidst the persistence of both the recent and the distant past.

It's not just about seeing. While proposing the inclusion of hearing, smell, touch and movement might seem a little bit extreme, these are all important modes of understanding in other fields and could be discussed in pretty much the same way that we have proposed visualization. For example, "hands-on-media history" has recently been proposed as novel methodology in exploring the role of media technologies (Hall \& Ellis, 2019). It could be applied directly to studying entrepreneurs doing context in increasingly digital environments. Research exploring entrepreneurship as embodied, for example, emphasizes that non-linguistic 
practices (movements, posture, gestures, facial expressions) along with a focus on entrepreneurs as "differently abled agents" represents an important cutting edge of work on entrepreneurial behavior, actions and identity (Kasperová \& Kitching, 2014).

In relation to our fascination with the visual, as elaborated in Part III of this book, there also is a need to acknowledge critical voices such as Teju Cole, writer, photographer, critic, who points to the role visuals play in serving the "powers that be", a position very much in line with the CPA approach we put forward in this book:

"And yet, perhaps even more insistently, on a day-by-day, week-byweek basis, photography implicitly serves the powers that be. To insist that contemporary photographic practice-and I mean to include a majority of the international news coverage in newspapers like this one-is generally made (and published) for the greater good is to misconstrue history, because it leaves out the question of 'Good for whom?' Certain images underscore an unbridgeable gap and a neverto-be-toppled hierarchy. When a group of people is judged to be 'foreign', it becomes far more likely that news organizations will run, for the consumption of their audiences, explicit, disturbing photographs of members of that group: starving children or bullet-riddled bodies. Meanwhile, the injury and degradation of those with whom readers perceive a kinship - a judgment often based on racial sympathy and class loyalties-is routinely treated in more circumspect fashion. This has hardly changed since Susan Sontag made the same observation in 'Regarding the Pain of Others' (2003), and it has hardly changed because the underlying political relationships between dominant and subject societies have hardly changed".

(Cole, 2019)

Therefore, we argue for bringing in (or back?) more subjectivity-by which we mean taking seriously the lived human experience of those we study and of our relationships with them-into our research-regardless of whether we label that engaged scholarship, verstehen, privileging the emic or something else. As we have emphasized, we need more collaboration, not only with those we study, but also with different scholars who bring in diverse views and tools of study. It is time to get involved again, to make our research relevant to the real world of everyday entrepreneurs, policymakers and society beyond the academy. Choosing to become involved, in whatever capacities and roles, is part of what we have introduced as the CPA in Part II of this book, and a fundamental part of what we see as our role as researchers doing contexts. This will force us to acknowledge the complexities of contextualizing entrepreneurship, and also make us question its apparent and taken-for-granted and false transparency. 


\section{Going Forward}

Such involvement does not imply that all of us need to go out into the field and talk to those we study, nor that we need to do engaged research or support interventions on behalf of everyday entrepreneurs. Involvement comes in many flavors, but for CPA-driven research, every flavor requires keeping in consideration who our research serves and who we wish it to serve. Whether such involvement renders our research less objective, because we are involved and acknowledging our own values and perspectives, we leave to the reader to decide (we don't think so-it makes us more human, open to "real-world problems" and less focused on the false idols of the "literature" rather than theoretical understanding (Staw, 1984)).

We know that we are opening up Pandora's box here, and by no means do we want to imply that our research should no longer strive for objectivity. However, as soon as we embrace the S-A-G framework and start applying a CPA, we have to face questions about our own involvement and engagement. In the best case, from our perspective, the scientist is no longer a "'disinterested observer' merely reporting the facts, but is regarded as an active participant, who through his or her actions, helps construct the nature of the facts, which then affect future actions and inquiries" (Rosnow \& Georgoudi, 1986, p. 19). As our role adjusts, so can the roles and the agencies of our research subjects. For social psychology, Morawski (1986) discussed the changed roles of subject-object, concluding: "Taking context seriously entails unpacking and renegotiating the very ideas of subject and experimenter, of the social relationships between them, and even of the relationships between social psychologists. In the end it necessitates attention to the ways we structure and warrant our knowledge claims and invalidate other contestants".

Ultimately, it is our choice and responsibility which themes and topics we pay attention to and to what extent we become involved and engaged. We cannot, of course simply wish away career pressures or those from funders and others. Both of us have made choices in picking research topics and developing research streams that allowed and required us to engage with entrepreneurs and policymakers and which thereby made us more subjectively involved than had we gone down another road.

Throughout this discussion, and throughout the book, one issue has repeatedly tugged at us. How should we understand the limits of our abilities to understand, never mind to give voice to others (Jack, Westwood, Srinivas, \& Sardar, 2011, p. 280)? One of us has received suggestions from several sub-Saharan scholars self-identifying as taking a "postcolonial" viewpoint that we should not attempt to understand or participate in conversations about activities in their countries unless we are willing to abandon the colonial concepts and theories on which our work is premised. We do not quite buy this argument, but we also cannot simply ignore it. Berger and Mohr (2016) provide a less-extreme version of what we see as a similar insight: "For example, to understand the 
decisions another person makes, one has to imagine the lack of choices which he faces. The well-fed are incapable of understanding the choices of the under-fed" (Berger \& Mohr, 2016, p. 102; English translation by authors). Again, we do not see this statement as absolutely true, and neither of us plans to starve ourselves in search of understanding entrepreneurship under research constraints. But we do believe that these messages provide fair warning against arrogance, especially when we try to study entrepreneurs whose circumstances may differ greatly from our own.

We would like to end this chapter and the book with a supportive and passionate call by Becker (2016, p. 221), as he argues for greater subjectivity in research: "Academic social science has so committed itself to objectivity and rigorous measurement that it has lost sight of the complementary virtues of subjective involvement (of both the maker and the consumers of scientific work) and rigorous observation. (...) Developing ideas worth putting to the rigorous tests of empirical research depends on having subjective experiences sufficiently broad to allow us to capture the state of mind of those whose behavior our theories are supposed to explain. If our subjectivity fails to take account of what those people really are thinking about and the perspectives they jointly bring to bear on their collective activity, then our theories will omit relevant variables, and our conclusions, will not, to use that language, explain much of the variance we are interested in. The world, in that way, punishes scientists who ignore subjectivity (...)". And, perhaps, we might hope, it rewards those who do not.

\section{References}

Aldrich, H., \& Ruef, M. (2018). Unicorns, gazelles, and other distractions on the way to understanding real entrepreneurship in America. Academy of Management Perspectives, 32(4), 458-472.

Alvesson, M., \& Kärreman, D. (2000). Taking the linguistic turn in organizational research: Challenges, responses, consequences. The Journal of Applied Behavioral Science, 36(2), 136-158.

Baker, T., \& Pollock, T. G. (2007). Making the marriage work: The benefits of strategy's takeover of entrepreneurship for strategic organization. Strategic Organization, 5(3), 297-312.

Baker, T., \& Welter, F. (2018). Contextual entrepreneurship: An interdisciplinary perspective. Foundations and Trends in Entrepreneurship, 14(4), 357-426.

Becker, H. S. (2016). Afterword. In D. Harper (Ed.), Good company: A tramp life (pp. 221-223). New York, Abingdon: Routledge.

Berger, J., \& Mohr, J. (2016). Der Siebte Mensch: Eine Geschichte über Migration und Arbeit in Europa (New edition). Frankfurt am Main: Fischer Taschenbuch.

Cole, T. (2019, February 6). When the camera was a weapon of imperialism. (And when it still is.). The New York Times Magazine. Retrieved from https:// nyti.ms/2UJjlGE

Cousins, M. (2017). The story of looking. Edinburgh: Canongate. 


\section{Going Forward}

Gartner, W. B. (2004). Achieving critical mess in entrepreneurship scholarship. In J. A. Katz \& D. Shepherd (Eds.), Corporate entrepreneurship (pp. 199-216). Amsterdam: Elsevier.

Hall, N., \& Ellis, J. (Eds.). (2019). Hands on media history: A new methodology in the humanities and social sciences. London: Routledge.

Jack, G., Westwood, R., Srinivas, N., \& Sardar, Z. (2011). Deepening, broadening and re-asserting a postcolonial interrogative space in organization studies. Organization, 18(3), 275-302.

Kasperová, E., \& Kitching, J. (2014). Embodying entrepreneurial identity. International Journal of Entrepreneurial Behaviour \& Research, 20(5), 438-452.

Mitchell, W. T. (1995). Picture theory: Essays on verbal and visual representation. Chicago, IL: University of Chicago Press.

Morawski, J. G. (1986). Contextual discipline: The unmaking and remaking of sociality. In R. L. Rosnow \& M. Georgoudi (Eds.), Contextualism and understanding in behavioral science (pp. 47-66). New York, NY: Praeger.

Rosnow, R. L., \& Georgoudi, M. (1986). The spirit of contextualism. In R. L. Rosnow \& M. Georgoudi (Eds.), Contextualism and understanding in behavioral science (pp. 3-22). New York, NY: Praeger.

Staw, B. M. (1984). Repairs on the road to rigor and relevance: Some unexplored issues in publishing organizational research. In L. L. Cummings \& P. J. Frost (Eds.), Publishing in the organizational sciences (pp. 85-97). Thousand Oaks, CA: Sage.

Welter, F., Baker, T., Audretsch, D. B., \& Gartner, W. B. (2017). Everyday entrepreneurship: A call for entrepreneurship research to embrace entrepreneurial diversity. Entrepreneurship Theory and Practice, 41(3), 311-321. 


\section{Author Biographies}

Ted Baker leads entrepreneurship efforts at Rutgers Business SchoolNewark \& New Brunswick. He is also Senior Fellow at the Bertha Centre for Social Innovation and Entrepreneurship and Honorary Professor at the University of Cape Town Graduate School of Business. He earned his $\mathrm{PhD}$ in sociology from the University of North Carolina at Chapel Hill and his MBA from the University of Chicago. Baker spent much of the first half of his adult life building a variety of technology-rich entrepreneurial ventures. His research explores entrepreneurship under resource constraints and adversity (for example, in the informal settlements around Cape Town, South Africa, and in the U.S. textile industry) focusing in particular on bricolage and improvisation as constructs useful for understanding resourceful behavior and organizational resilience. His recent work builds on the social psychology of identity to explain founders' responses to adversity, continuation of organizing efforts and choices of organizational structure. His research has been published in leading academic journals such as the Academy of Management Journal, Administrative Science Quarterly, Journal of Business Venturing, Entrepreneurship Theory and Practice and Strategic Entrepreneurship Journal.

Friederike Welter leads the IfM Bonn (Institut für Mittelstandsforschung), a renowned policy research institute on entrepreneurship and small business in Germany, and has held a professorship for entrepreneurship and small business management at the University of Siegen, Germany, since February 2013. Previously, she worked at Jönköping International Business School, Sweden (2008-2013). Welter has broad experiences in applied and policy-related research on entrepreneurship and small business, much of it in an international context. Her main research interests are the nature of entrepreneurship and entrepreneurial behaviour in different contexts, women entrepreneurship and entrepreneurship/Small and Medium-sized Enterprises (SME) policies. She has published widely in international and national academic journals, has authored and edited several monographs and handbooks, and also is Senior Editor of Entrepreneurship Theory and Practice. 


\section{Index}

academic writing 134

Academy of Management 82

Academy of Management Review (AMR) 5

action-oriented bracketing 43

advance industrial economies 120

adversity 43

Ai Weiwei 147, 149

Albarráncabrera 56

Anderson, Alistair 136

Arab women entrepreneurs 46

art photography 146-150

asymmetries 19

Balinese culture and society 140

Berger, John 55, 145-148

big data methods 132

"Big Five" trait names 6

Blank, Steve 74

bricolage see entrepreneurial bricolage

business contexts 20

business owners 58, 109

business school entrepreneurship $87-88$

business schools $85-86,87$

"Caught in Freedom" project 148-149

chef entrepreneurs 50-51

Chinese entrepreneurship 22, 131-132

cognitions and contexts 47-49

Cole, Teju 171

collaboration: cross-disciplinary 116 ; ethnographic methods 117-118;

Harper and Willie 141; with local researchers 115-116

commercial entrepreneurs 49-50

conservatism 80-81, 83-85, 88

context dimensions 10 contexts: classifying aspects of 73 ; defined 5; defining 3-7; discrete 5 ; doctoral students and 7; entrepreneurship researchers and 6-7; entrepreneurship shaped by 19-22; entrepreneurs impacting 23-24; as environments 7; environments as 14; historical time and 18; interactions between different levels of 20; interactions within institutional 19; omnibus 5 ; organizational studies on 5; as "out there" 7; as social constructs 48 ; surroundings and 8 ; talking and (see language); theorizing (see theorizing contexts); see also doing contexts

contextualism, defined 4

contextualization: contingency approaches to 74-75; as counterproductive 72-73; extreme versions of 73 ; individual as endpoint of 118-119; limits of 75-76; shaping meaning making 152; theory development of 8 ; unbounded 5, 167

contextualizing theory, theorizing context vs. 72

contextual relativism 75-76

control variables 106-107

corpus linguistics (CL) 130, 131-132

critical discourse analysis 131

Critical Process Approach (CPA): collaboration and 114-118; construction of 109-110; control variables 106-107; description of 71, 105; driving research 167-168; excluding the "other" 108-110; goal of 79-80; intellectual servitude and 88-89; key informants 
107-108; methodological publication standards 112-113; S-A-G framework and 168; silent participation in 106-108; small-n vs. large-n in 121-122; theory development 105-106

cross-disciplinary collaborations 116 , 121-122

cross-sector partnerships 115 crowdfunding 49-50, 111-112

cultural-cognitive institutions 16-17

cultural institutions 17

cultural relativism 3,118

digital technologies 15

discourse analysis 130, 131

distributed resources 42

diva stereotype 52

Döblin, Alfred 146

doing contexts: description of 167 ; enactment perspective of 41-43; entrepreneurs as 41; ethnographies and 118; images as layers of 153 ; implications of 71 ; linguistic methods for 130-133; seeing and 53-59; talking and 49-53; visualizing and 138-139

emerging economies 19, 22, 113, 120-121

enactment: as action-oriented bracketing 41-43; context through 41-47; see also doing contexts entrepreneurial bricolage 42-43, 46 entrepreneurial change making 44 entrepreneurial innovations 111-112 entrepreneurship: constraints and affordances for 119; contextualizing 7-10, 74; cultural-cognitive institutions impact on 16-17; decontextualized 74; environments for 6-7; impact of contexts on 14-19; phenomenological approaches 117; sector-based studies of 14-15

Entrepreneurship as Practice group 114

entrepreneurship education $84-88$ entrepreneurship research: active participants in 172 ; bias toward conservatism $80,83-84$; contributions to "the literature" 83; critical 85-86; emancipation of 88; embodied 170-171; historical methods in 17; imagery in 150-154; language and 49-53; narrative process 133-136; nurturing niches in 113; policymakers and 81 ; research paper significance 83 ; semiotic analysis 136-139; serving practice 81-84; serving scholars 80-81; serving universities 84-88; theory-driven vs. theoretically interesting 82-83; visual methods in 137; writing style in 134-136 environments, as context 14 ethnic entrepreneurship 16, 19-20, $22,23-24$

ethnomethodology 117-118

European Commission 93-94

extreme relativism 73,74

family business researchers 138

family entrepreneurship 20

Farm Security Administration 147

founder identity 110

functionalist notion of entrepreneurship 91-92, 109-110

gap-spotting 77-78

Gartner, Bill 134-135

gendered industries 17

gendered linguistic systems 52

gendered stereotypes 59

gender gap 52

gender in entrepreneurship 52, 55; see also women entrepreneurs/ entrepreneurship generalizability 122

ghettoization 113-114

Global Entrepreneurship Monitor 16

Global North 120

Global South 95, 120

glocalisation 21

Good Company (Harper) 142

guest worker migration 147-148

Hambrick, Don 82

hands-on-media history 170

Harper, Douglas 140-143, 153-154

high-growth entrepreneurship 23

high-tech entrepreneurship 90

history dimension 10

household enterprises 20

households 15, 16

idiographic explanations, nomothetic explanations vs. 75-76

imagery in research 150-154 


\section{Index}

imagination, visualizing through 56-59

inequality of entrepreneurial opportunity 92

informal entrepreneurship: control over 132; defying institutions 44-45; economic and social development of 95; families in cross-border 20

informants see key informants initial public offerings (IPOs) 166, 168

institutional dimension 10

institutional entrepreneurship 23

institutional holes see institutional voids

institutionalization of research fields 81-82

institutional voids $19,94-95$

institutions: cultural 17; normative 17, 20; as place-bound 21-22; regulatory 19,20

intersectionality 119

isomorphisms 42

Jobs, Steve 87-88

Jordan 46

key informants 107-108, 112, 121

Lampedusa (Migrant Image Research Group) 148

Lange, Dorothea 146-147, 153

language: in entrepreneurship 49-53; forming contexts 47-49; gendering and 52 ; images driving 151-152; metaphors and 51-52, 57, 132-133; non-verbal cues 49, 129; resource access and 49; seeing linked to 54-55; shaping entrepreneurial cognitions 47-49; social constructs and 48; of spatial contexts 50; verbal and non-verbal cues 49, 51-52; see also linguistic styles

large-n studies 121-123

lean start-up model 74

"Learn to See" project 151-152

Lebanon 46

legacies of non-compliance 17-18

life cycle metaphors 51

linguistic methods in entrepreneurship 130-133 linguistic styles: crowdfunding and 49-50; of social and commercial entrepreneurs 49-50; see also language

lived business narratives 138

local researchers 115

loose coupling 6

media technologies 170

Meiselas, Susan 151

Merkel, Angela 149

metaphors 51-52, 57, 132-133, 137-138

migrant economy, women entrepreneurs in 45-46

Migrant Image Research Group 148

"Migrant Mother" (Lange) 147

migration, in photography 146-150

missing entrepreneurs 93-94

Mitchell, Ron 155

Mittelstand model 24, 119-120; see also Silicon Valley Model (SVM) of entrepreneurship

Mohr, Jean 146-148

motivations, heterogeneity of 110

multidimensionality of context 5-6, 110

necessity-based entrepreneurship 16-17, 110

Nepal 46

networks see social networks

nomothetic explanations, idiographic explanations vs. 75-76

non-business-related social ties 15

non-Silicon Valley Model

entrepreneurship 111

non-verbal cues 49, 129

normative institutions 17,20

opportunity-based entrepreneurship 16-17

opportunity entrepreneurs 54-55

Organisation for Economic Cooperation and Development (OECD) 93-94

“other" cultures 86-87, 106, 108, 146, 166-167

“other" entrepreneurship 92-93, 120,168

Palestinian entrepreneurs 46 paradigm of the research field 81 
"People of the 20th Century" project 145

photographic ethnography 142

photography: experimental innovation and 140; exploring society in 145; Lange, Dorothea 146-147; limitations of 142-143; migration and 146-150; Mohr, Jean 146-147; photo interviewing 140-141; reading 151; scene distortion in 142-143; self-created images 141; social constructs and 54; stylistic devices 143; techniques in 143-144; visual anthropology and 139-144 photo interviewing 140-141

photovoice 141-142

place identities 44

poetry $134-135$

portfolio entrepreneurship 16

post-Soviet countries 22, 45, 95

private equity firms $152-153$

problematizing 77-79

professional schools $85-86$

qualitative research 107-108, 121-122

quantitative methods in entrepreneurship 78, 107, 121-123, 169

\section{race 112}

refugee entrepreneurship 150

refugees 148-149; see also migration

regulatory institutions $16,19,20$

relativism 4

research see entrepreneurship research

research ghettos 113-114

resource-constrained entrepreneurs 46, 122

"Roma Reisen" 146

Rosenfeld, Rachel 71

Sander, August 145-146

Sander, Erich 145

scholars 80-81

seeing: in constructing contexts 53-56; gendered stereotypes and 59; language linked to 54-55; memory and 170; opportunity entrepreneurs and 54-55; sensemaking and 54; visual analysis and 58-59; visualizing internally as 56-59; see also photography self-created images 141

semiotics in entrepreneurship studies

136-139

sensemaking 54

Seventh Man, A (Berger) 147-148

sign reversals 6

silent participation 106-108, 112

Silicon Valley Model (SVM) of entrepreneurship 24, 91-93, 110-112, 119-120, 166-167; see also Mittelstand model

simplicity, accuracy and generalizability (S-A-G) 79-80, 95, 168

small-n studies 121-123

Smith, Robert 58, 136

social contexts 48

social imaginaries $56-57$

socialist heritage $17-18$, 20-21, 95

social networks 15,21

social research, observational

approach to 140

socio-economic geographies 94

spatial and temporal dimensions 10 , 56-57

spatial contexts 20,21, 50

spontaneous ventures 111

sports industry 15

standard model of entrepreneurship 25-26

Standard Oil New Jersey (SONJ) 142-143

stereotyping 52-53, 153

talking see language

Taylor, Paul 147

technology-based entrepreneurship 90

temporary ventures 111

textile and apparel entrepreneurs 43

text mining 132

theorizing contexts: contextualizing theory vs. 72 ; defined 72 ; as problematizing 77-78; researcher choice and 78-79

TIME (Telecom, IT, media, entertainment) industry 15

time, as context 18

translocal embeddedness 21

transnational entrepreneurs 45 , 149-150 
“Traveling People” (Sander) 145

troubling see problematizing

uninteresting entrepreneurship 109-110

university entrepreneurship programs 84-88

Uzbek Women Business Association 115

Varieties of Capitalism (VOC) 24 venture capital financing 166 ventures, temporary 111

verbal cues 49

verbal imagery 52

Verstehen 141

visual see seeing

visual analysis 58-59

visual elements of entrepreneurship 57-58

visual ethnography 138

visualizing 56-59, 145-150

visualizing entrepreneurship 144 visual management studies 138-139 visual metaphors 137-138

visual stereotyping 153

women entrepreneurs/ entrepreneurship: barriers to 45; challenging gender-averse institutions 45; as deficient 93; discriminatory verbal and nonverbal language 52 ; feminized picture of 89-90; in former Soviet countries 45; in high-tech regions 90; language used to describe 52; in migrant economy 45-46; motivations of 110; normative institutions and 20; public media representation of 89-90; regulatory institutions and 20; resource constraints for 46; stereotypical representations of 52-53 women photographers 154 writing style in entrepreneurship 133-136 